RICARDO GANDOLFI

MÉTODO EXERGÉTICO PARA CONCEPÇÃO E AVALIAÇÃO DE DESEMPENHO DE SISTEMAS AERONÁUTICOS

São Paulo 
RICARDO GANDOLFI

\section{MÉTODO EXERGÉTICO PARA CONCEPÇÃO E AVALIAÇÃO DE DESEMPENHO DE SISTEMAS AERONÁUTICOS}

Tese apresentada à Escola Politécnica da Universidade de São Paulo para a obtenção do título de Doutor em

Engenharia

São Paulo 
RICARDO GANDOLFI

\section{MÉTODO EXERGÉTICO PARA CONCEPÇÃO E AVALIAÇÃO DE DESEMPENHO DE SISTEMAS AERONÁUTICOS}

Tese apresentada à Escola Politécnica da Universidade de São Paulo para a obtenção do título de Doutor em Engenharia

Área de Concentração: Energia e Fluidos Orientador: Prof. Dr. Silvio de Oliveira Jr.

\section{São Paulo}


Este exemplar foi revisado e alterado em relação à versão original, sob responsabilidade única do autor e com a anuência de seu orientador.

São Paulo, de agosto de 2010.

Assinatura do autor

Assinatura do orientador

FICHA CATALOGRÁFICA

Gandolfi, Ricardo

Método exergético para concepção e avaliação de desem penho de sistemas aeronáuticos / R. Gandolfi. -- ed.rev. -- São Paulo, 2010. $203 \mathrm{p}$.

Tese (Doutorado) - Escola Politécnica da Universidade de São Paulo. Departamento de Engenharia Mecânica.

1. Termodinâmica 2. Aeronaves 3. Aeronáutica (Sistemas) I. Universidade de São Paulo. Escola Politécnica. Departamento de Engenharia Mecânica II. t. 
Dedico este trabalho à minha filha e à minha esposa. 


\section{Agradecimentos}

Ao meu pai por ter me incentivado a entrar no programa de doutorado da Poli, à minha esposa e filha pela compreensão de tantos finais de semanas que passei estudando, à minha mãe, irmãs, tios, avós, prima e sobrinhos pelo amor, carinho, apoio e incentivo em todos os momentos.

Ao Prof. Dr. Silvio de Oliveira pela orientação precisa e motivadora, pela confiança depositada em mim ao longo dos anos, por me mostrar a visão acadêmica das coisas e pelo suporte nos momentos mais difíceis.

À EPUSP pela oportunidade e pela verba à mim concedida para participação do $22^{\circ}$ congresso ECOS em Foz do Iguaçu.

Agradeço à EMBRAER pela confiança depositada em mim e pelo tempo concedido para realização deste trabalho.

Ao amigo Luiz Pellegrini pelos vários artigos que fizemos juntos, pelo respaldo técnico e pelas experiências de vida trocadas durante nossos almoços e cafés.

Aos engenheiros Cesare Tona e Paolo Raviolo do Politécnico di Milano e ao engenheiro Paulo Salvador da Poli pelo suporte na utilização do programa GSP.

Aos(À) amigos(a): Luciano Martinez Stefanini, Celso Yukio Nakashima, Wallace Turcio, Marcelo Pustelnik, Sandro Tavares Conceição, Fernando Gonçalves Gastaldo e Luciana Sayuri pelo suporte.

Aos amigos do LETE: Amaury, Carlos, Hector, Cyro, Juan, Cadu e Julio pelas trocas de experiências e conversas agradáveis.

Aos companheiros de banda Edu, Christiano, Clauber, Daniel e Carlos pelos momentos relaxantes de ensaio em estúdio e inúmeros shows realizados. 
Por fim, agradeço à vida que me possibilitou conviver com todas as pessoas aqui citadas e concretizar esta tese. 
Comece fazendo o que é necessário, depois o que é possível, e de repente você estará fazendo o impossível.

(São Francisco de Assis) 


\section{Resumo}

A tendência da indústria aeronáutica comercial é o desenvolvimento de aviões mais eficientes em termos de consumo de combustível e custos operacionais diretos. No que diz respeito ao consumo de combustível, algumas estratégias da indústria aeronáutica são o uso de uma aerodinâmica mais eficiente, materiais mais leves e motores e sistemas mais eficientes. O motor turbo jato convencional fornece potência elétrica para os sistemas de cabine (luzes, entretenimento, cozinha) e aviônicos, potência hidráulica para os sistemas de controle de voo e potência pneumática para proteção contra formação de gelo e unidade de controle ambiental. Motores mais eficientes e diferentes tipos de arquiteturas de sistemas, como os sistemas mais elétricos, são promessas para reduzir o consumo de combustível. A fim de comparar os processos energéticos das arquiteturas de sistemas e motor numa mesma base, a exergia é o verdadeiro valor termodinâmico que deve ser utilizada como ferramenta de decisão para projeto de sistemas, motores e aeronaves, assim como parâmetro de otimização. Trabalhos de outros autores focaram apenas em redução da exergia destruída e nenhum trabalho apresentou um método harmonizador que consolide os parâmetros já existentes e crie outros parâmetros comparativos entre sistemas.

Este trabalho propõe um método baseado em análise exergética para concepção e avaliação de sistemas aeronáuticos, que pode ser aplicado ao projeto de uma nova aeronave desde as fases de estudos conceituais e ante projeto até a fase de definição. O método pode suportar o projeto completo de uma aeronave como um único sistema, pois integra todos os subsistemas numa mesma estrutura. Os principais índices propostos neste trabalho são: exergia destruída, rendimento exergético, consumo específico de exergia, exergia destruída na missão e eficiência exergética da missão.

Este trabalho também apresenta resultados comparativos ao aplicar o métiodo exergético entre versões de uma mesma aeronave comercial regional, considerando sistemas de gerenciamento de ar (sistema de extração pneumática, unidade de controle ambiental e sistema de proteção contra formação de gelo) convencionais e mais elétricos. Para tanto, quantificam-se os requisitos de dimensionamento e faz-se a modelagem termodinâmica dos sistemas convencionais e mais elétricos, assim como a modelagem do motor para ambas as 
versões da aeronave. Os resultados da aplicação do método exergético evidenciam que os sistemas convencionais de gerenciamento de ar são os maiores consumidores de exergia de uma aeronave e que a substituição por sistemas mais elétricos é uma boa alternativa para melhorar a eficiência termodinâmica da mesma. Considerando os mesmos requisitos exergéticos de tração entre as duas versões de aeronaves, a abordagem mais elétrica apresenta maiores rendimentos exergéticos de missão em torno de 0,5\%. Entretanto, a análise completa também leva em conta as diferenças de peso e arrasto entre as duas versões de aeronaves, a qual evidencia que a escolha por sistemas mais elétricos deve ser guiada pela variação dos requisitos de tração que esta aeronave possui com relação ao avião com sistemas convencionais.

Palavras-chave: análise exergética, aeronave, sistemas aeronáuticos, sistemas mais elétricos, método. 


\section{Abstract}

A tendency of the commercial aeronautical industry is to develop more efficient aircraft in terms of fuel consumption and direct operational costs. Regarding fuel consumption, some strategies of the aeronautical industry are to use more efficient aerodynamics, lightweight materials and more efficient engines and systems. The conventional turbo fan engine mainly provides electric power for cabin systems (lights, entertainment, galleys) and avionics, hydraulic power for flight control systems and bleed air for ice protection and environmental control systems. More efficient engines and different types of systems architectures, such as more electric systems, are a promise to reduce fuel consumption. In order to compare the energy processes of systems and engine architectures at the same basis, exergy is the true thermodynamic value that shall be used as a decision tool to aircraft systems and engine design, and also as an optimization tool. Other works have focused only on reduction of exergy destruction and none have presented a method that harmonizes and consolidates the existing comparative parameters and creates new parameters among systems.

This work proposes a method based on exergy analysis for conception and assessment of aircraft systems, that can be applied to an aircraft project from the conceptual and preliminary designs to the detail design. The method can support the design of the complete vehicle as a system and all of its subsystems in a common framework. The main proposed parameters in this work are: exergy destruction, exergy efficiency, specific exergy consumption, mission exergy destruction and mission exergy efficiency.

This work also presents comparative results by applying the method to conventional and more electric version of the same regional commercial aircraft, considering conventional and electric air management systems (bleed system, environmental control system and ice protection system). In order to, sizing requirements are evaluated and thermodynamic models are performed for both conventional and more electric air management systems, and also engine models are performed for both aircraft. Results show that conventional air management systems are the higher exergy consumers among aircraft systems and the substitution for more electric systems is a good alternative to improve the aircraft thermodynamic efficiency. Considering the same thrust exergy requirements for both aircraft, 
the more electric version presents higher mission exergy efficiency around $0.5 \%$. However, a complete trade-off also takes into account weight and drag differences of both versions, which makes evident that the selection for more electric systems must be driven by the variation of thrust requirements between more electric and conventional aircraft.

Keywords: exergy analysis, aircraft, aircraft systems, more electric systems, method. 


\section{Índice de Figuras}

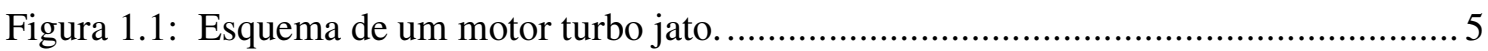

Figura 1.2: Sistemas consumidores do ar comprimido extraído dos motores.......................... 6

Figura 1.3: Integração do SEP esquerdo com outros sistemas da aeronave. .......................... 7

Figura 1.4: Servo-válvula eletro-hidráulica (MUSSI, 2008).......................................... 10

Figura 1.5: Principais diferenças com relação à extração de potência entre motores para avião com sistemas convencionais e sistemas mais elétricos. ............................................ 15

Figura 1.6: Sistema de ar condicionado mais elétrico com ciclo a ar................................. 16

Figura 1.7: Sistema de ar condicionado mais elétrico com ciclo de compressão e vapor. ...... 17

Figura 1.8: Aerofólio com aquecedores elétricos (AL-KHALIL 2001)............................... 18

Figura 1.9: Sistema de proteção eletro-expulsivo (GORAJ, 2004) .................................... 19

Figura 1.10: Atuador não deformado (esquerdo) e deformado (direito) (http://www.coxandco.com/aerospace/lowpower_ice_protection.html)........................ 19

Figura 1.11: Atuador eletro-hidrostático (MIZIOKA, 2009)........................................... 21

Figura 1.12: Esquema de atuador eletro-hidrostático (TAKEBAYASHI, 2004).................. 21

Figura 1.13: Esquema de atuador eletromecânico padrão com engrenagens e parafuso

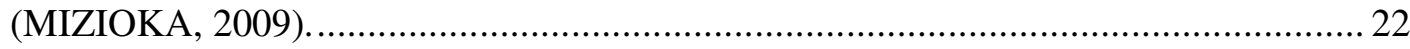

Figura 1.14: Esquema de atuador eletromecânico sem caixa de engrenagens (MIZIOKA,

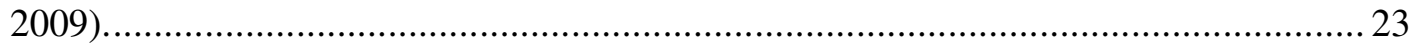

Figura 2.1: Variação do preço em dólares do barril de petróleo (linha vermelha) e combustível $\begin{array}{llllll}\text { aeronáutico (linha } & \text { preta) entre } & 2003 & \text { e } & 2009\end{array}$ (http://www.iata.org/whatwedo/economics/fuel_monitor/price_development.htm)....... 28

Figura 2.2: Rolls Royce Trent 1000 e GE Genx, ambos utilizam o conceito sem extração de ar comprimido (fontes: http://www.geae.com/, http://www.rolls-royce.com/civil/index.jsp ).

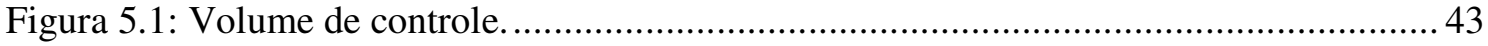

Figura 6.1: Método exergético no ciclo de desenvolvimento de aeronaves. ......................... 48

Figura 6.2: Demandas e penalidades impostas ao motor e à estrutura para uma aeronave convencional.

Figura 6.3: Demandas e penalidades impostas ao motor e à estrutura para uma aeronave mais

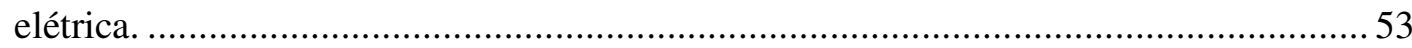


Figura 7.1: As quatro forças do voo, voo nivelado horizontal (esquerda) e voo em subida com

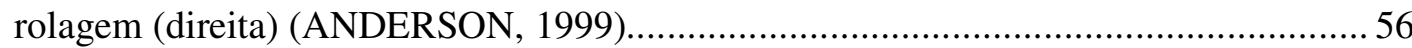

Figura 7.2: Diagrama de forças para o voo nivelado e estabilizado (ANDERSON, 1999)..... 61

Figura 7.3: Forças que agem num avião durante o pouso e a decolagem............................. 62

Figura 7.4: Diagrama de forças e velocidade para subida estabilizada (ANDERSON, 1999).63

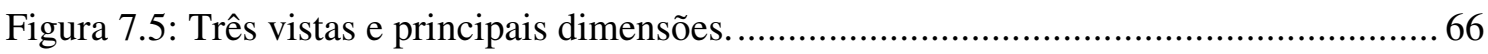

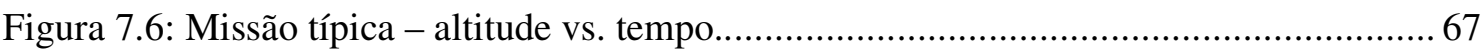

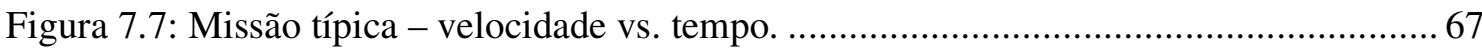

Figura 8.1: Efeitos considerados na troca de calor da cabine (GANDOLFI, 2004)...............71

Figura 8.2: Parede composta da fuselagem (GANDOLFI, 2004)................................... 73

Figura 8.3: Relação entre fluxo de calor por radiação e convecção do corpo humano versus temperatura de bulbo seco para ar estagnado. (SAE, 1990a) ....................................... 77

Figura 8.4: Relação entre fluxo de entalpia relacionado à perda de água do corpo humano versus temperatura de bulbo seco para ar estagnado. (SAE, 1990a) ............................ 77

Figura 8.5: Definição dos parâmetros usados na análise do problema................................ 86

Figura 8.6: Distribuição típica da eficiência de coleta local $\beta$ sobre a borda de ataque de um

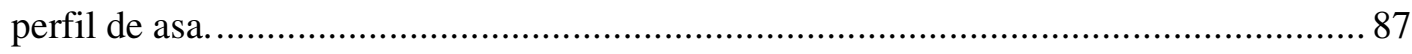

Figura 8.7: "Gas path standard component library"e "Standard control component library" do

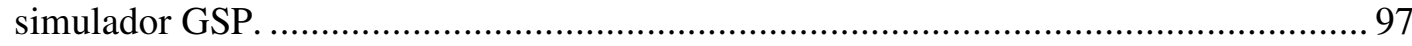

Figura 8.8: Esquema das fases conceituais da modelagem do motor................................ 99

Figura 8.9: Modelo completo do motor para o avião com sistemas convencionais.............. 100

Figura 8.10: Esquema do sistema de extração pneumática (SEP) e unidade de controle

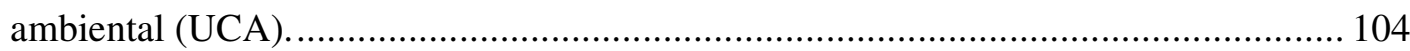

Figura 8.11: Esquema do sistema de proteção contra gelo para o avião com sistemas

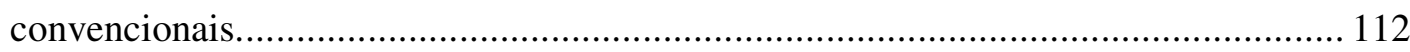

Figura 8.12: Modelo completo do motor para o avião com sistemas mais elétricos.............. 114

Figura 8.13: Esquema do sistema de controle ambiental para o avião com sistemas mais

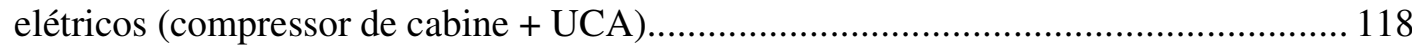

Figura 9.1: Requisitos de tração por motor............................................................... 123

Figura 9.2: Distribuição das irreversibilidades do avião com sistemas convencionais durante a fase de cruzeiro a $11277 \mathrm{~m}$, com sistema de antigelo desligado. 126

Figura 9.3: Distribuição das irreversibilidades do avião com sistemas convencionais durante a fase de espera a $4572 \mathrm{~m}$, com sistema de antigelo ligado. 127 
Figura 9.4: Distribuição das irreversibilidades o avião com sistemas mais elétricos durante a fase de cruzeiro a $11277 \mathrm{~m}$, com sistema de antigelo desligado. 127

Figura 9.5: Distribuição das irreversibilidades do avião com sistemas mais elétricos durante a fase de espera a $4572 \mathrm{~m}$, com sistema de antigelo ligado. 128

Figura 9.6: Distribuição da exergia destruída por fase de voo para o avião com sistemas convencionais

Figura 9.7: Distribuição da exergia destruída por fase de voo para o avião com sistemas mais elétricos 129

Figura 9.8: Eficiência exergética do avião com sistemas convencionais durante a missão com o sistema de antigelo desligado

Figura 9.9: Eficiência exergética do avião com sistemas convencionais durante a missão com o sistema de antigelo ligado. 133

Figura 9.10: Eficiência exergética do avião com sistemas mais elétricos durante a missão com o sistema de antigelo desligado 134

Figura 9.11: Eficiência exergética do avião com sistemas mais elétricos durante a missão com o sistema de antigelo ligado. 135

Figura 9.12: Comparação entre eficiência exergética da missão e do motor para o avião com sistemas convencionais (missão com o sistema de antigelo desligado). 136

Figura 9.13: Comparação entre eficiência exergética da missão e do motor para o avião com sistemas mais elétricos (missão com o sistema de antigelo desligado).

Figura 9.14: Consumo específico de exergia para o avião com sistemas convencionais durante a missão com o sistema de antigelo desligado. 138

Figura 9.15: Consumo específico de exergia para o avião com sistemas convencionais durante a missão com o sistema de antigelo ligado. 138

Figura 9.16: Consumo específico de exergia para o avião com sistemas mais elétricos durante a missão com o sistema de antigelo desligado.

Figura 9.17: Consumo específico de exergia para o avião com sistemas mais elétricos durante a missão com o sistema de antigelo ligado. 140

Figura 9.18: Consumo específico de exergia para a estrutura dos aviões com o sistema de antigelo ligado. 141

Figura 10.1: Requisitos de extração exergética do motor para os sistemas convencionais e mais elétricos. 144

Figura 10.2: Requisitos de tração para o estudo de sensibilidade 145

Figura 10.3: Requisitos exergéticos de tração para o estudo de sensibilidade 145 
Figura 10.4: Variação da eficiência exergética do motor do avião com sistemas mais elétricos ao longo da missão no estudo de sensibilidade 146

Figura 10.5: Variação da eficiência exergética do motor para diferentes missões. 147

Figura 10.6: Variação do consumo de combustível do motor para diferentes missões 148

Figura C.1: Definição do ponto de projeto do coletor dinâmico. C.1

Figura C.2: Definição do ponto de projeto do ventilador. C. 2

Figura C.3: Definição do ponto de projeto do compressor. C. 2

Figura C.4: Definição do ponto de projeto da câmara de combustão C.3

Figura C.5: Definição do ponto de projeto da câmara de combustão (combustível utilizado).

Figura C.6: Definiçãa do ponto de projeto da turbina 1 . .............................................. C.4

Figura C.7: Definição do ponto de projeto da turbina 2. .................................................. C.5

Figura C.8: Definição do ponto de projeto do misturador ................................................. C.6

Figura C.9: Mapa do ventilador para o fluxo interno. ....................................................... C.7

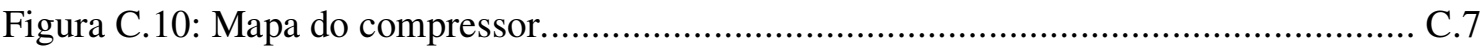

Figura C.11: Mapa da turbina de alta pressão. .......................................................... C.8

Figura D.1: Eficiência exergética do o avião com sistemas convencionais durante a missão com o sistema de antigelo desligado, usando ambiente de referência fixo no solo....... D.1

Figura D.2: Eficiência exergética do o avião com sistemas convencionais durante a missão com o sistema de antigelo ligado, usando ambiente de referência fixo no solo D.2

Figura D.3: Consumo específico de exergia para o avião com sistemas convencionais com o sistema de antigelo desligado, usando ambiente de referência fixo no solo. D.3

Figura D.4: Consumo específico de exergia para o avião com sistemas convencionais com o sistema de antigelo ligado, usando ambiente de referência fixo no solo. D.3 


\section{Índice de Tabelas}

Tabela 1.1: Tabela comparativa entre modelos energéticos.

13

Tabela 8.1: Requisitos de insuflamento de ar para o sistema de controle ambiental.

Tabela 8.2: Cargas térmicas e requisitos de insuflamento de ar para dimensionamento em condições extremas de aquecimento de cabine.

Tabela 8.3: Cargas térmicas e requisitos de insuflamento de ar para dimensionamento em condições extremas de resfriamento de cabine. 81

Tabela 8.4: Requisitos de insuflamento de ar para pressurização. 84

Tabela 8.5: Resultados para cálculo dos requisitos de antigelo da asa, empenagem e entrada do motor na condição crítica de formação de gelo. ....................................................... 95

Tabela 8.6: Vazões mássicas e pressões do SEP e UCA - sistema de antigelo desligado..... 109

Tabela 8.7: Vazões mássicas e pressões do SEP e UCA - sistema de antigelo ligado.......... 109

Tabela 8.8: Temperaturas do SEP e UCA - sistema de antigelo desligado. ........................ 110

Tabela 8.9: Temperaturas do SEP e UCA - sistema de antigelo ligado. ............................. 110

Tabela 8.10: Potência na turbina da UCA, eficiência e fluxo de calor do pré-resfriador e fluxos de calor do trocador primário e secundário da UCA - sistema de antigelo desligado.

Tabela 8.11: Potência na turbina da UCA, fluxo de calor e eficiência do pré-resfriador e fluxos de calor do trocador primário e secundário da UCA - sistema de antigelo ligado.

Tabela 8.12: Vazões de ar estabelecidas para o sistema de antigelo (semi asa, semi empenagem e um motor).

Tabela 8.13: Pressões e temperaturas para o sistema de antigelo da asa e empenagem........ 113

Tabela 8.14: Pressões e temperaturas para o sistema de antigelo do motor. 113

Tabela 8.15: Taxas de transferência de calor do sistema de antigelo (semi asa, semi empenagem e um motor).

Tabela 8.16: Vazões mássicas e pressões do sistema de controle ambiental mais elétrico... 119

Tabela 8.17: Temperaturas do sistema de controle ambiental mais elétrico.

Tabela 8.18: Potência do compressor de cabine, potência demandada ao gerador, potência na turbina da UCA e fluxos de calor do trocador primário e secundário da UCA do sistema de controle ambiental mais elétrico. 
Tabela 9.1: Irreversibilidades associadas aos sistemas convencionais (sistema de proteção

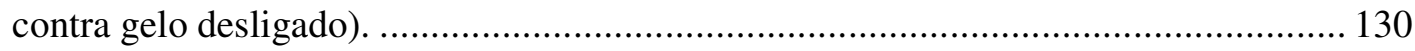

Tabela 9.2: Irreversibilidades associadas aos sistemas convencionais (sistema de proteção

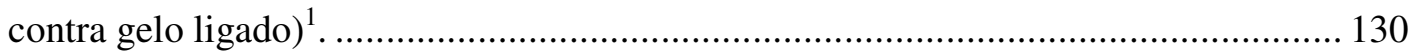

Tabela 9.3: Irreversibilidades associadas aos sistemas mais elétricos (sistema de proteção contra gelo desligado).

Tabela 9.4: Irreversibilidades associadas aos sistemas mais elétricos (sistema de proteção contra gelo ligado $)^{2}$.

Tabela A.1: Taxas de exergia do motor, SEP e sistema elétrico do avião com sistemas convencionais (sistema de antigelo desligado).

Tabela A.2: Taxas de exergia do sistema hidráulico, UCA e cabine do avião com sistemas convencionais (sistema de antigelo desligado).

Tabela A.3: Taxas de exergia do motor, SEP e sistemas elétrico do avião com sistemas convencionais (sistema de antigelo ligado).

Tabela A.4: Taxas de exergia do sistema hidráulico, UCA e cabine do avião com sistemas convencionais (sistema de antigelo ligado).

Tabela A.5: Taxas de exergia do sistema de antigelo convencional. A.3

Tabela B.1: Taxas de exergia do motor, compressor de cabine e sistema elétrico do avião com sistemas mais elétricos (sistema de degelo desligado).

B. 1

Tabela B.2: Taxas de exergia do sistema hidráulico, UCA e cabine do avião com sistemas mais elétricos (sistema de degelo desligado).

B. 1

Tabela B.3: Taxas de exergia do motor, compressor de cabine e sistema elétrico do avião com sistemas mais elétricos (sistema de degelo ligado).

Tabela B.4: Taxas de exergia do sistema hidráulico, UCA e cabine do avião com sistemas mais elétricos (sistema de degelo ligado)..................................................... B.2

Tabela B.5: Taxas de exergia do sistema de degelo mais elétrico. ................................... B.3

Tabela D.1: Irreversibilidades associadas aos sistemas convencionais (sistema de proteção contra gelo desligado e usando ambiente de referência fixo no solo)........................ D.4

Tabela D.2: Irreversibilidades associadas aos sistemas convencionais (sistema de proteção contra gelo ligado e usando ambiente de referência fixo no solo $)^{1}$........................ D.4 


\section{Lista de Abreviaturas e Siglas}

\begin{tabular}{|c|c|}
\hline $\mathrm{AC}$ & Advisory Circular \\
\hline $\mathrm{AEH}$ & Atuadores eletro-hidrostáticos \\
\hline AEM & Atuadores eletromecânicos \\
\hline AIAA & American Institute of Aeronautics and Astronautics \\
\hline ANAC & Agência Nacional de Aviação Civil \\
\hline $\mathrm{CA}$ & Corrente Alternada \\
\hline CAS & Calibrated Air Speed \\
\hline $\mathrm{CC}$ & Corrente Contínua \\
\hline EASA & European Aviation Safety Agency \\
\hline EES & Engineering Equation Solver \\
\hline FAA & Federal Aviation Administration \\
\hline FADEC & Full Authority Electronic Control \\
\hline GSP & Gas Turbine Simulation Program \\
\hline ICAO & International Civil Aviation Organization \\
\hline HEPA & High Efficiency Particulate Air \\
\hline IDEA & Integrated Digital Electrical Aircraft \\
\hline JAR & Joint Aviation Requirements \\
\hline JSF & Joint Strike Fighter \\
\hline MEA & More Electric Aircraft Program \\
\hline NASA & National Safety Agency \\
\hline NRL & National Aerospace Laboratory \\
\hline ONERA & Office National D'etudes Et De Recherches Aérospatiales \\
\hline PAO & Poli-alfa-olefina \\
\hline POA & Power Optimized Aircraft \\
\hline RBAC & Regulamentos Brasileiros de Aviação Civil \\
\hline SEP & Sistema de Extração Pneumática \\
\hline TAS & True Air Speed \\
\hline TIMES & Totally Integrated More Electric Systems \\
\hline TUDelft & Delft University of Technology \\
\hline UCA & Unidade(s) de Controle Ambiental \\
\hline
\end{tabular}




\section{Lista de Símbolos}

\section{Símbolos Latinos}

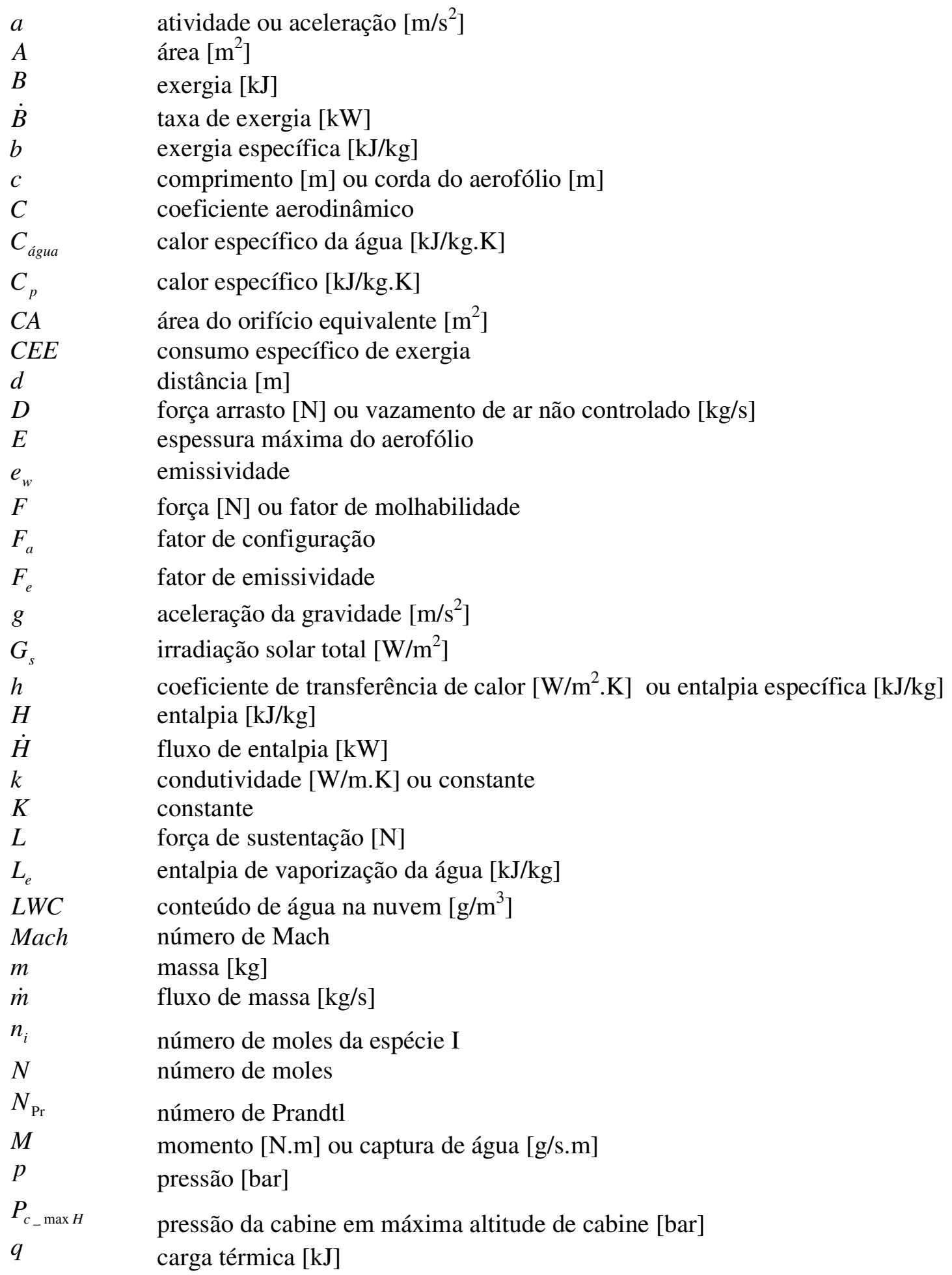




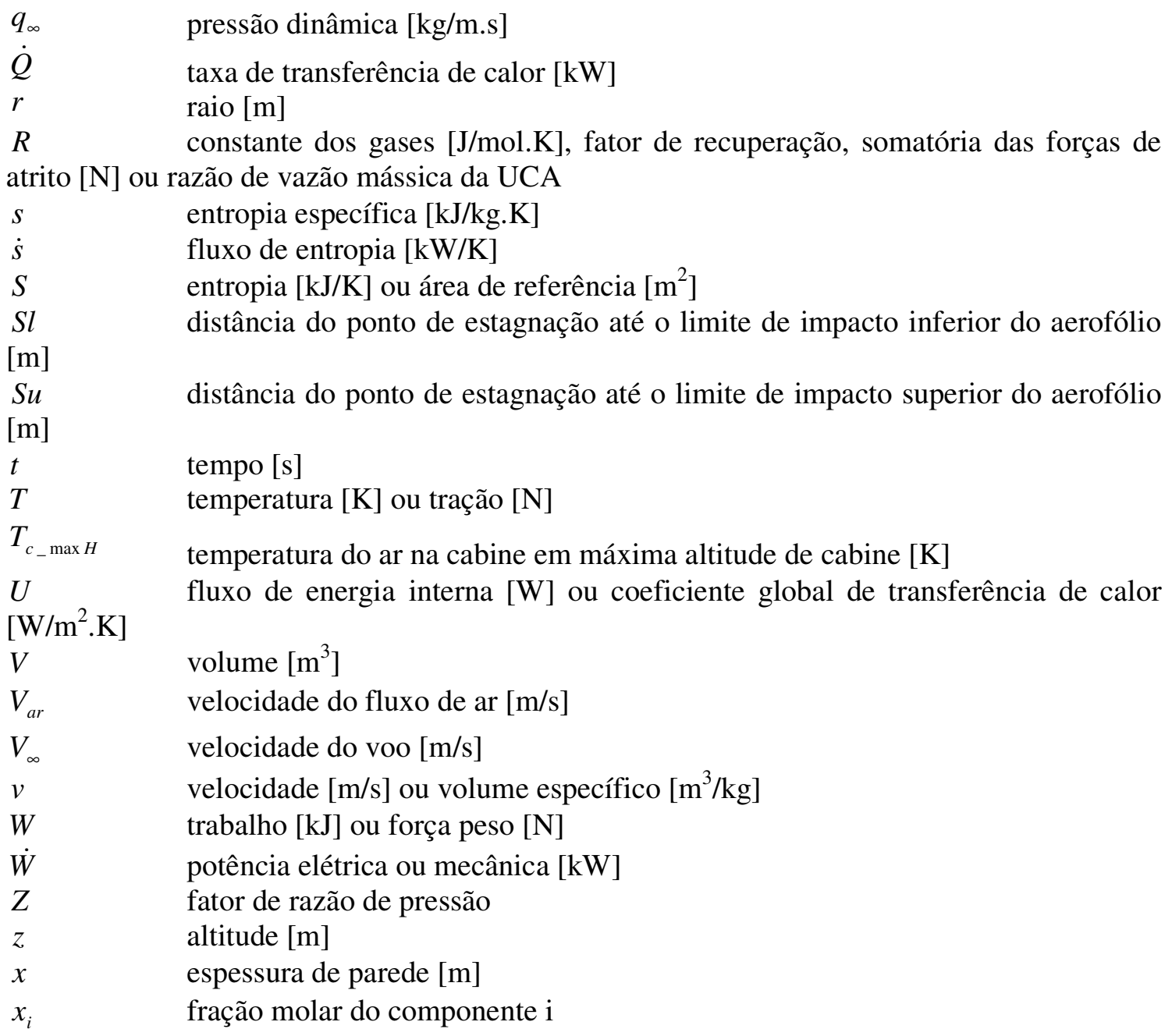

\section{Símbolos Gregos}

$\begin{array}{ll}\Delta & \text { variação } \\ \eta & \text { eficiência exergética } \\ \beta & \text { eficiência de coleta } \\ \gamma & \text { razão de calores específicos para o } \operatorname{ar}(1,4) \\ \sigma & \text { constante de Stefan-Boltzmann }\left[\mathrm{W} / \mathrm{m}^{2} \cdot \mathrm{K}^{4}\right] \\ \tau & \text { transmissividade } \\ \mu & \text { potencial químico }[\mathrm{J} / \mathrm{mol}] \\ \mu_{R} & \text { coeficiente de atrito entre pneus e solo } \\ \dot{\sigma} & \text { taxa de entropia produzida }[\mathrm{kW} / \mathrm{K}] \\ \varepsilon & \text { ângulo entre a direção do voo e a tração }\left[{ }^{\circ}\right] \text { ou efetividade de trocador de calor } \\ \theta & \text { ângulo de arfagem }\left[^{\circ}\right] \\ \varphi & \text { ângulo de rolagem }\left[{ }^{\circ}\right] \\ \rho & \text { densidade }\left[\mathrm{kg} / \mathrm{m}^{3}\right] \\ \psi & \text { eficiência total de coleta de água }\end{array}$




\section{Subscritos}

0

a

aw

b

c

c_max H

cin

Comb

Comp

cond

conv

D

Dest

e

ele

ex

ext

F

f

hum

i

L

$\mathrm{m}$

M

$\mathrm{Mec}$

$\mathrm{p}$

$\mathrm{P}$

PR

pot

Q

qui

r

$\mathrm{rad}$

$\mathrm{s}$

SEP

sk

TC

Vent

W referente à sustentação zero

ambiente ou camada da fuselagem

adiabática de parede

camada da fuselagem

cabine

máxima altitude de cabine

cinética

combustível

Compressor do motor

condução

convecção

arrasto

destruído

entrada, externo ou referente à arrasto parasita

elétrico

exergético

externo

atrito

física

humano

espécie $i$, interno ou camada

sustentação

média

momento

mecânica

projetada

perfeição ou pressão

pré-resfriador

potencial

transferência de calor

química

recuperação

radiação

saída ou ambiente externo

Sistema de Extração Pneumática

borda de ataque

trocador de calor

ventilador do motor

parede externa da fuselagem ou referente ao arrasto de onda 


\section{Sobrescritos}

0

estado de referência

estado de referência restrito

molar

taxa de variação temporal

sistema 


\section{SUMÁRIO}

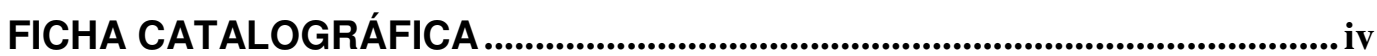

Resumo ....................................................................................................................... ix

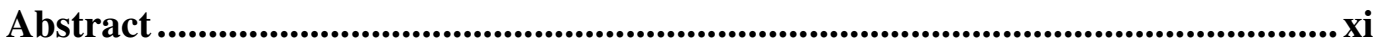

Índice de Figuras................................................................................................xiii

Índice de Tabelas.............................................................................................................. xvii

Lista de Abreviaturas e Siglas ...................................................................................... xix

Lista de Símbolos ..................................................................................................................... $\mathrm{xx}$

1 Introdução.............................................................................................................

1.1. A aeronave comercial com sistemas convencionais .................................. 1

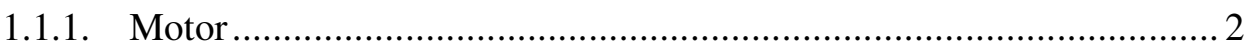

1.1.2. Sistema de extração pneumática ......................................................... 5

1.1.3. Sistema de ar condicionado ............................................................

1.1.4. Sistema de proteção contra gelo .........................................................

1.1.5. Sistema de atuação ………………………………………………...... 10

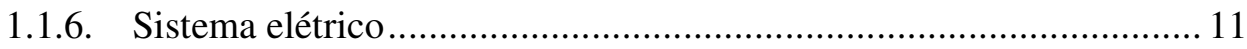

1.2. A aeronave com sistemas mais elétricos ............................................... 13

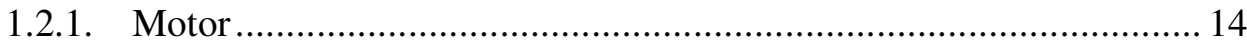

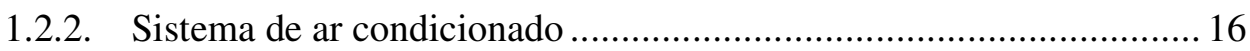

1.2.3. Sistema de proteção contra gelo ........................................................ 17

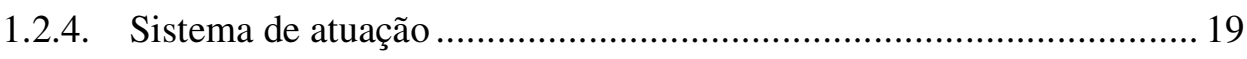

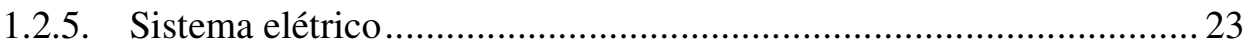

1.3. Histórico sobre aeronaves com sistemas mais elétricos............................2 24

2 Descrição da Necessidade ....................................................................................... 28

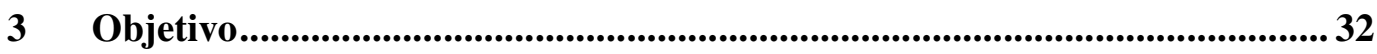

4 Revisão Bibliográfica: Análise Exergética na Indústria Aeroespacial ...........33

$5 \quad$ Fundamentação Teórica ...................................................................................... 37

5.1. Processos reversíveis e irreversíveis ...................................................... 37

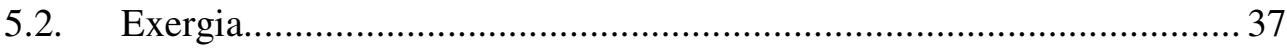




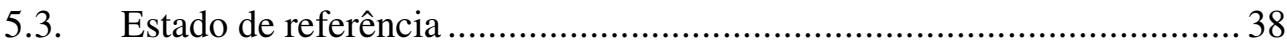

5.4. Estado de referência restrito ....................................................... 38

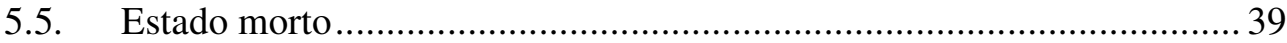

5.6. Estado de referência restrito para análise de sistemas aeronáuticos ........ 39

5.7. Componentes da exergia ............................................................... 40

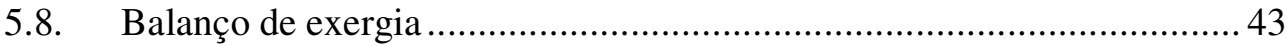

5.9. Rendimento ou eficiência exergética .............................................. 45

6 Método Exergético Para Concepção e Avaliação de Arquiteturas de Sistemas Aeronáuticos ................................................................................................................................. 47

6.1. Abordagem para o avião convencional ............................................... 48

6.2. Abordagem para o avião mais elétrico.............................................. 52

$7 \quad$ Modelagem do Desempenho do Avião .......................................................55

7.1. Equações gerais do movimento ..................................................... 55

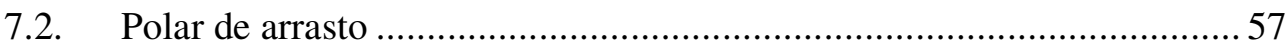

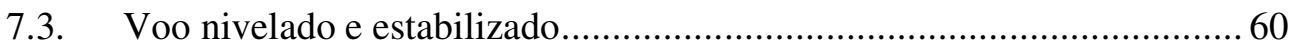

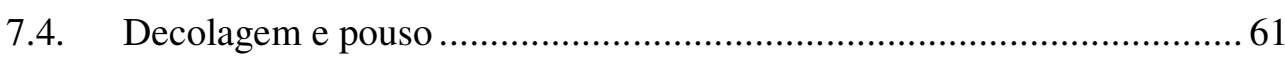

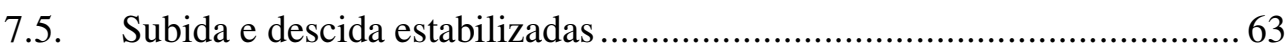

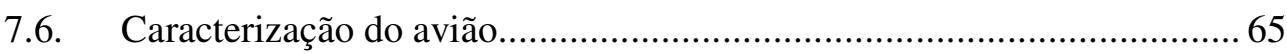

$8 \quad$ Modelagem de Sistemas Aeronáuticos ......................................................68 68

8.1. Requisitos de dimensionamento dos sistemas de gerenciamento de ar ...68 68

8.1.1. Requisitos de ar para o sistema de controle ambiental..................... 68

8.1.2. Requisitos de ar para o dimensionamento do sistema de antigelo...... 85

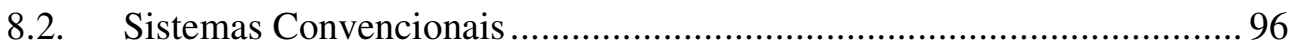

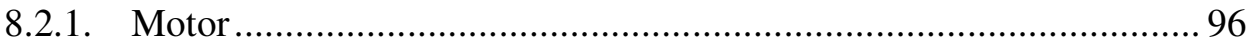

8.2.2. Sistemas de extração pneumática e sistema de controle ambiental .. 102

8.2.3. Sistema de proteção contra gelo .................................................. 112

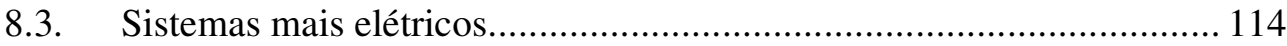

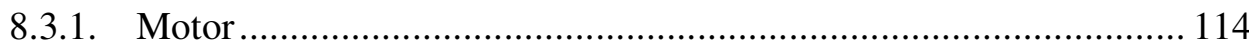

8.3.2. Sistema de controle ambiental ................................................. 116

8.3.3. Sistema de proteção contra gelo .................................................. 121

9 Análise Exergética Comparativa Entre Avião Com Sistemas Convencionais e Avião Com Sistemas Mais Elétricos ................................................................................ 122

9.1. Considerações no cálculo da exergia .............................................. 123

9.2. Resultados do balanço exergético entre sistemas .............................. 125 


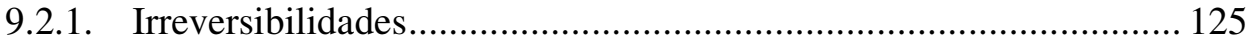

9.2.2. Eficiências exergéticas ............................................................ 132

9.2.3. Consumo específico de exergia (CEE)....................................... 137

9.2.4. Conclusões da análise exergética................................................. 141

10 Análise de Sensibilidade do Motor .................................................................. 143

10.1.1. Comparação dos requisitos exergéticos de uma aeronave ............. 143

10.1.2. Comparação da eficiência exergética e consumo de combustível.. 146

10.1.3. Conclusões da análise de sensibilidade ....................................... 148

11 Conclusões e Recomendações ............................................................... 150

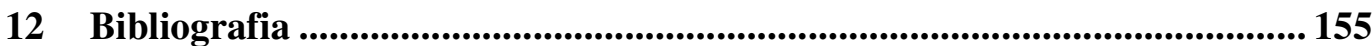

Apêndice A. Taxas de exergia relacionadas ao avião com sistemas convencionais A.1

Apêndice B. Taxas de exergia relacionadas ao avião com sistemas mais elétricos $100 \%$ (mesmo peso) B.1

Apêndice C. Modelagem do ponto de projeto do motor ...................................... C.1

Apêndice D. Resultados adotando ambiente de referência fixo no solo........... D.1 


\section{Introdução}

A concepção dos sistemas aeronáuticos começa durante as primeiras fases do desenvolvimento de aeronaves, mais precisamente após a definição dos principais parâmetros aeronáuticos e configurações geométricas principais (envergadura, área da asa, diâmetro da fuselagem, posicionamento dos motores, etc.). Após a fase de concepção, os sistemas são projetados nas fases subseqüentes onde também são feitos os estudos de instalação daqueles na aeronave.

Os estudos que avaliam diferentes arquiteturas e concepções energéticas de sistemas começam na fase de estudos conceituais, onde são estimados dados básicos como vazões de ar extraído do motor, extrações de potência de eixo do motor, consumos de potência elétrica pelos sistemas e capacidade de geração elétrica dos geradores. Durante a avaliação de diferentes arquiteturas, são estimados os impactos na aeronave em termos de peso, arrasto e consumo de combustível.

\subsection{A aeronave comercial com sistemas convencionais}

Uma aeronave comercial típica é basicamente composta por partes que possuem funções complementares para que o voo possa ser concretizado. Uma aeronave é composta por partes estruturais como asa, fuselagem e empenagem, sistema propulsor (turbo jato, turbohélice ou motor a pistão, cuja função principal é fornecer o empuxo necessário para o voo) e sistemas principais: sistema elétrico, sistema aviônico, sistema hidráulico, sistema de atuação, trem de pouso, sistema pneumático, sistema de ar condicionado, sistema de proteção contra gelo e chuva e sistema de combustível.

A aeronave também possui alguns sistemas secundários como: iluminação, navegação, oxigênio suplementar, indicação e gravação, comunicação, piloto automático, proteção contra fogo, água e resíduos e unidade de potência auxiliar. Os principais sistemas responsáveis pelo grande consumo de potência dos motores e que são avaliados nesse trabalho são: elétrico, pneumático, ar condicionado, proteção contra gelo, atuação e hidráulico. 
Os sistemas de atuação possibilitam ao piloto ter o controle das superfícies de comando da aeronave, que são responsáveis pelo controle da trajetória do avião. Esse sistema pode ser feito mecanicamente por meio de cabos de comando que são ligados diretamente ao manche do piloto, geralmente usado em aviões pequenos nos quais não são necessárias grandes forças para controlar o avião. Conforme as aeronaves foram ficando mais pesadas, as forças envolvidas nas superfícies de comando também aumentaram tornando necessário potenciar o sistema por meio de atuadores hidráulicos. Esse tipo de sistema é considerado eletro-mecânico, pois utiliza ainda cabos de comando e atuadores hidráulicos.

Os sistemas eletro/eletrônicos podem ser divididos em sistema elétrico e sistema aviônico. O sistema elétrico é responsável pela parte de geração, armazenamento e distribuição de potência elétrica, além de iluminação interna e externa da aeronave. O sistema aviônico tem as funções de navegação, comunicação e indicação. Auxilia em funções como monitoramento de dados do voo, velocidade da aeronave, altitude, condições atmosféricas, monitoramento dos sistemas e permite meios da tripulação se comunicar com estações de solo e outras aeronaves. Além disso, o sistema aviônico possibilita a navegação por instrumentos viabilizando voos em quaisquer condições atmosféricas.

Por fim, os sistemas chamados ambientais englobam ar condicionado, pressurização, oxigênio suplementar, antigelo ou degelo, proteção contra chuva e pneumático (sangria de ar quente do compressor do motor e distribuição). O sistema de ar condicionado engloba os equipamentos, controles e indicadores que fornecem e distribuem o ar para os compartimentos ocupados para efeito de ventilação (ar de renovação para passageiros e tripulação), pressurização, controle de umidade e temperatura (aquecimento e/ou resfriamento da cabine). Isto pode ser feito utilizando um ciclo aberto a ar, mais convencional e o mais utilizado na indústria aeronáutica, ou um ciclo fechado a vapor que utiliza um fluído refrigerante. As máquinas de ciclo a ar utilizam ar à alta pressão e temperatura, extraído do compressor do motor como fonte de energia para controle de temperatura e renovação do ar da cabine.

\subsubsection{Motor}

O sistema propulsivo é composto basicamente pelo conjunto de motores instalados em uma aeronave e todos os controles associados a eles. Ele é responsável pela geração de tração 
para mover a aeronave, potência elétrica, pneumática e hidráulica. Para tanto, o motor converte a energia química do combustível nas formas solicitadas pela aeronave.

Os motores mais comumente utilizados na aviação comercial são os turbo jatos, com alta razão de derivação (razão entre o fluxo de ar direcionado para a saída e o fluxo de ar direcionado ao núcleo), geralmente de 5:1. Esses motores são compostos por uma entrada de ar, um ventilador, um ou mais estágios de compressão, câmara de combustão, turbinas com um ou mais estágios de expansão, uma saída dos gases da combustão, que pode ter diversos formatos, e um controlador. A Figura 1.1 mostra um esquema de um motor turbo jato.

A entrada de ar é o primeiro estágio do motor e é responsável pela tomada de ar do ambiente. A entrada de ar do motor também é responsável por garantir um nível mínimo de organização do escoamento, a aderência da camada limite mesmo em diversos ângulos de ataque, um fluxo de massa adequado e uma velocidade de escoamento que não exceda os limites do ventilador. Para isso, a entrada de ar do motor tem o formato de um bocal convergente/divergente. $\mathrm{O}$ ar que entra no motor passa por um duto convergente que, além de garantir a aderência da camada limite acelera o escoamento. Após essa contração, o fluxo de ar passa por uma etapa de expansão, onde a velocidade é reduzida até níveis adequados para entrada no ventilador. A região de menor área, denominada garganta, funciona como restritor no fluxo de massa e não permite uma entrada de ar excessiva.

Após a entrada de ar, o fluxo de ar passa pelo ventilador. O ventilador é responsável por aproximadamente $80 \%$ da tração dos motores turbo jato com alta razão de derivação. Ao passar pelo ventilador, o escoamento sofre uma pequena compressão e uma conseqüente elevação da temperatura além de um grande aumento da velocidade. Após a saída do ventilador, o fluxo de ar é divido em duas partes: um segue para a derivação e outra para o núcleo. O fluxo de ar da derivação segue diretamente para a saída e é responsável pela maior parte da tração do motor, enquanto que a parte que segue para o núcleo passará por mais um estágio de compressão. Nesta etapa ocorre a primeira extração de ar para alimentar o sistema pneumático.

O fluxo do núcleo passa então pela compressão que pode conter vários estágios ou conjuntos de compressores. Nesta etapa o ar tem a sua pressão e temperatura elevadas. e ocorrem extrações de ar para alimentar o sistema pneumático. Podem ser utilizados mais que 
um pórtico de extração para alcançar diversas configurações de pressão e temperatura do ar extraído.

Após o estágio de compressão, o fluxo de ar do núcleo segue para a câmara de combustão. Nesta etapa o ar é misturado com combustível e queimado. A queima libera a energia química contida no combustível gerando gases de combustão que sofrem um grande aumento de temperatura e velocidade de escoamento sem grandes alterações de pressão.

Os gases de combustão então seguem para a etapa de expansão, onde terão pela frente um ou mais estágios de turbina. Os estágios de turbina transformarão a entalpia do escoamento em potência mecânica com a rotação do eixo ao qual as pás estão ligadas. Esses eixos por sua vez estão ligados ao ventilador e aos compressores movendo esses estágios iniciais do motor fazendo do motor um ciclo retro alimentado. Além disso, os eixos do motor são responsáveis pela geração de potência elétrica e hidráulica, com auxílio de gerador elétrico e bombas hidráulicas acionados pelos eixos.

Após a expansão dos gases de combustão nos estágios de turbina e, transformação da entalpia do escoamento em potência mecânica disponível, o fluxo de ar do núcleo segue para a saída do motor. A exaustão desses gases é responsável por uma pequena parcela da tração e por uma grande parte do ruído. Além disso, nessa região, há também a mistura dos gases de combustão com o fluxo de ar que seguiu pela derivação. Para tornar essa mistura o mais eficiente possível, existem diversas formas de dispositivos que misturam os gases de uma forma mais suave, contribuindo para aumentar a eficiência do motor e reduzir o ruído. 


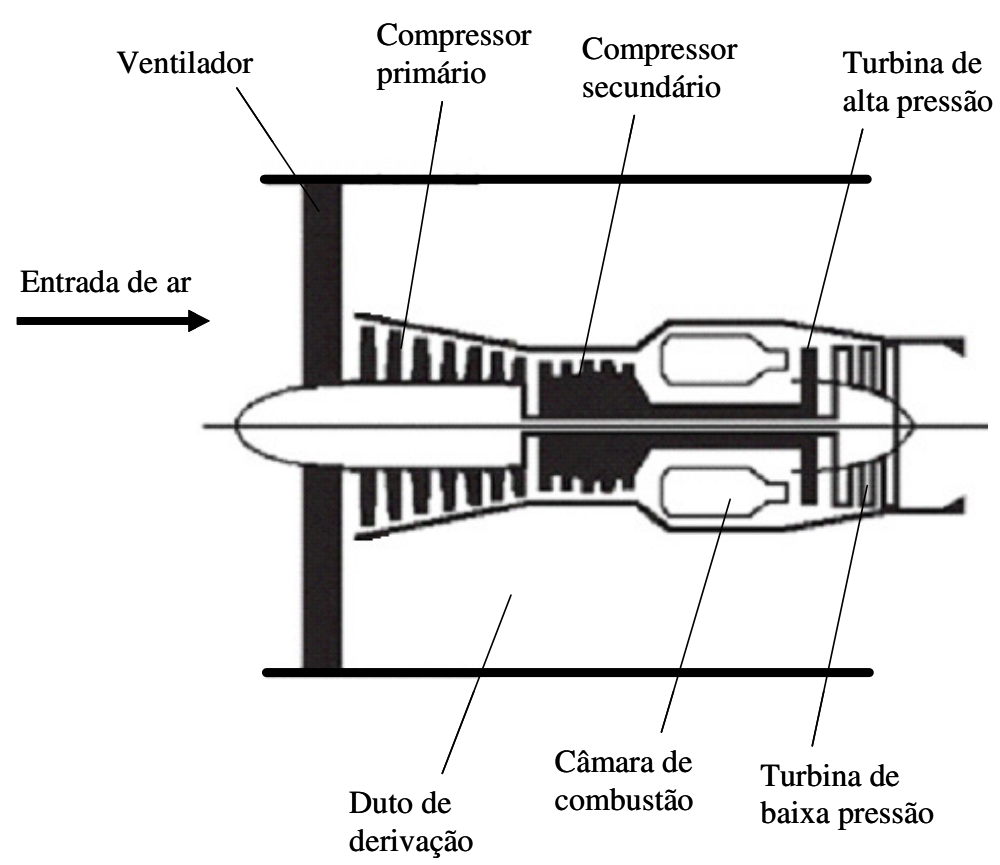

Figura 1.1: Esquema de um motor turbo jato.

A potência de eixo para acionamento dos geradores elétricos e bombas hidráulicas é fornecida por uma caixa de engrenagens ligada diretamente ao eixo do ventilador do motor. A caixa de engrenagens é um equipamento complexo, volumoso e responsável por uma parte significativa da manutenção do motor.

\subsubsection{Sistema de extração pneumática}

O propósito do sistema de extração pneumática (SEP) é o suprimento de ar comprimido, com controle de temperatura e pressão, durante todas as fases do voo e em operações em terra. $\mathrm{O}$ ar é obtido por meio de sangria do motor por válvulas localizadas no estágio intermediário ou no estágio de alta pressão do compressor, ou de sangria da unidade de potência auxiliar.

O SEP fornece ar para o sistema de ar condicionado, pressurização, sistema antigelo ou degelo, sistema de partida das turbinas entre outros, como mostra a Figura 1.2. O sistema pneumático também pode pressurizar os tanques de combustível, tanques de água e os reservatórios hidráulicos. Os sistemas de ar condicionado, pressurização de cabine e pressurização de tanques utilizam continuamente o ar comprimido, enquanto os sistemas de 
proteção contra gelo das asas, empenagens e entradas das turbinas e sistema de partida do motor o utilizam intermitentemente.

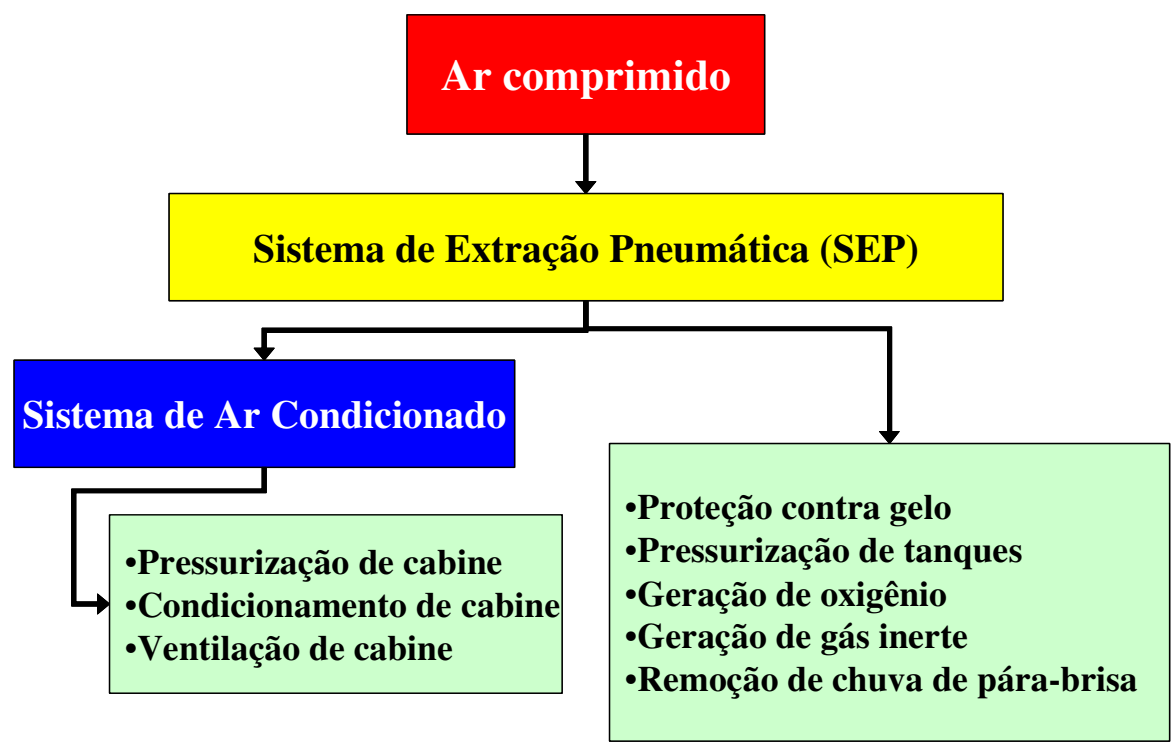

Figura 1.2: Sistemas consumidores do ar comprimido extraído dos motores.

O SEP é formado basicamente pelos seguintes componentes:

- Válvulas anti-retorno: previnem o escoamento reverso sob certos modos de operação e condições de falha, como rompimento de duto;

- Válvulas reguladoras de pressão: regulam a pressão a jusante da válvula;

- Válvulas de corte: possuem função de isolamento de linhas;

- Válvulas de modulação: controlam a vazão;

- Pré-resfriadores ou trocadores de calor primários: resfriam o ar sangrado do motor para atingir níveis aceitáveis e seguros de temperatura nos dutos;

- Sensores (pressão e temperatura): usados para controle da pressão e temperatura das linhas de ar e para detectar o mau funcionamento do sistema que resulta em corte do fornecimento de ar para a linha defeituosa.

O ar extraído dos motores passa por um trocador de calor primário a fim de evitar temperaturas próximas à de auto-ignição do combustível (requisito de certificação). Após passar pelo trocador de calor primário, uma parte do ar é direcionado ao sistema de antigelo da asa e estabilizador e outra para o sistema de ar condicionado. O controle é feito em torno de um valor de pressão monitorado constantemente. Sensores distribuídos ao longo da linha 
servem para auxiliar o controle e também detectar vazamentos. A interconexão do sistema pneumático esquerdo e direito é feita pela válvula de isolamento. Esta válvula permite alimentar o antigelo da asa esquerda e UCA esquerda com o sistema pneumático direito, e vice-versa. A Figura 1.3 mostra os principais componentes do SEP esquerdo.

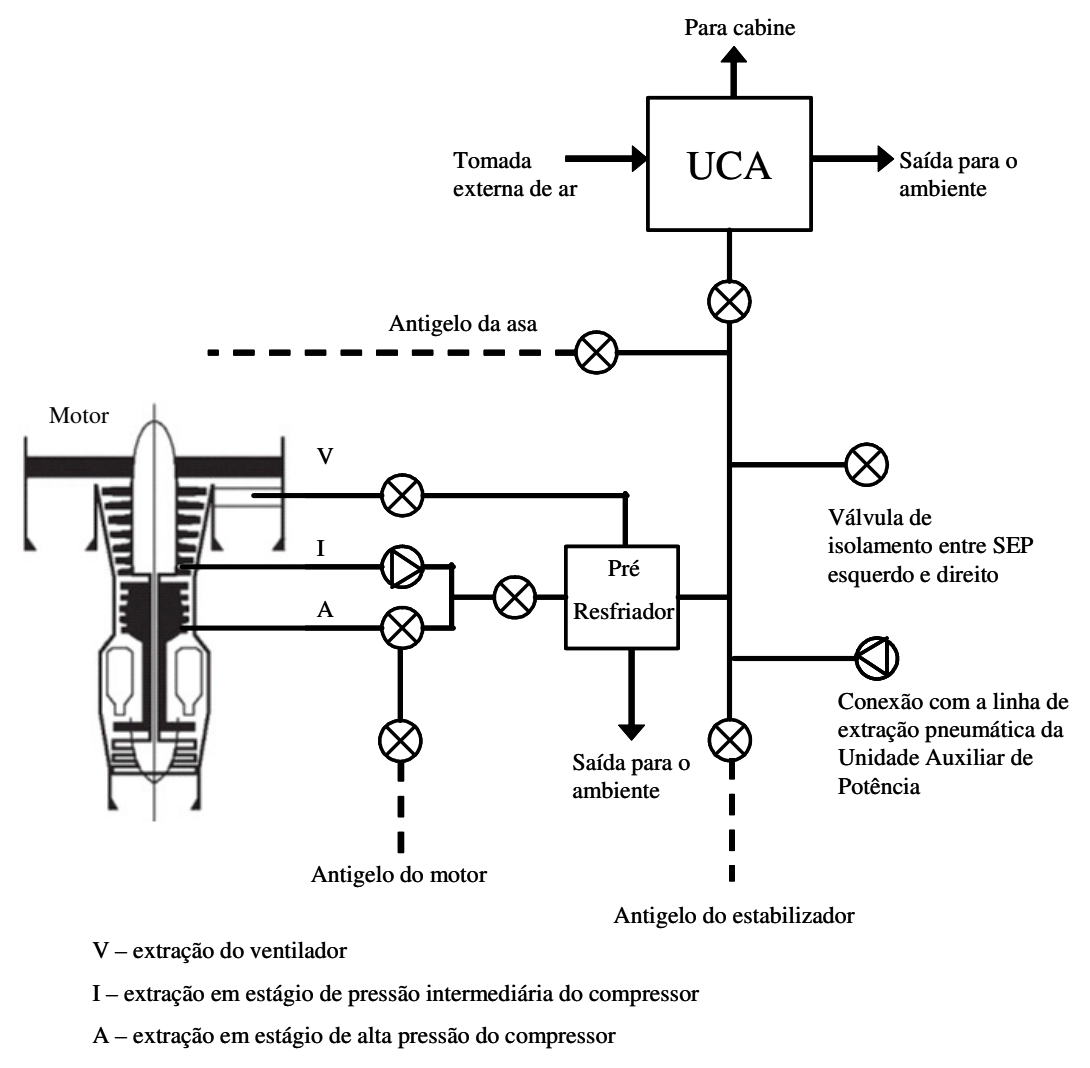

Figura 1.3: Integração do SEP esquerdo com outros sistemas da aeronave.

\subsubsection{Sistema de ar condicionado}

Por várias razões é desejável voar a alta altitude, uma vez que a distância percorrida por unidade de massa de combustível aumenta com a altitude. Além disso, quanto maior a altitude menor a probabilidade de encontrar condições adversas de tempo (turbulências, condições formadoras de gelo, precipitações atmosféricas, etc.). Por outro lado, uma operação em elevadas altitudes envolve o uso de um sistema de pressurização que mantém o ambiente interno da cabine em altitudes mínimas (abaixo de um valor máximo, ou seja, pressão acima de um valor mínimo), com mínimas taxas de mudança de altitude de cabine durante transições 
para que as necessidades fisiológicas e de conforto dos passageiros e tripulação sejam asseguradas. Além disso, um sistema de oxigênio suplementar deve ser incorporado à aeronave para ser acionado em casos de despressurização e garantir que essas necessidades fisiológicas de passageiros e tripulação sejam atendidas até que a aeronave desça para altitudes seguras para a fisiologia humana.

O sistema de ar condicionado do avião tem como função principal garantir condições de sobrevivência e de conforto aos passageiros e tripulação em quaisquer condições de voo. $\mathrm{O}$ sistema de ar condicionado é composto pelos equipamentos associados à ventilação, aquecimento, resfriamento, controle de umidade e contaminantes do ar nos compartimentos ocupados por pessoas, carga e aviônicos. O sistema de ar condicionado deve assegurar um ambiente confortável para tripulação e passageiros.

Para garantir o cumprimento de requisitos operacionais, os compartimentos ocupados devem ser ventilados sempre que o avião estiver em operação. Para satisfazer este requisito o sistema deve operar normalmente com a fonte de ar embarcada (motores e unidade auxiliar de potência), podendo ser também operado em solo a partir de fontes externas. No caso de falha do sistema principal, a ventilação deve ser suprida por um sistema de emergência.

A qualidade do ar da cabine depende da quantidade de ar de renovação (ar externo) fornecido e da taxa de geração de contaminantes no interior da cabine. A taxa de ar externo admitido deve ser suficiente para diluição dos contaminantes a níveis que não causem desconforto e prejuízos à saúde. Parte do ar externo pode ser substituída por ar recirculado, desde que este seja tratado para remoção de contaminantes. Os sistemas de ventilação da cabine dos aviões podem usar somente ar sangrado ou uma mistura de ar sangrado com ar recirculado. Um sistema de ar condicionado típico deve fornecer uma quantidade suficiente de ar para satisfazer os requisitos mínimos de ventilação, diluição das concentrações de dióxido e monóxido de carbono e controle de odores. $\mathrm{O}$ ar recirculado passa por filtros de particulados, que devem ser do tipo HEPA ("High Efficiency Particulate Air"). Alguns aviões que operam em ambientes onde altos níveis de ozônio são esperados necessitam de conversores catalíticos, para transformar o ozônio em oxigênio. Além disso, são usados também precipitadores eletrostáticos e adsorvedores. 
O sistema de ar condicionado é composto por uma ou mais unidades de controle ambiental (UCA) que, normalmente, são baseadas nos ciclos de compressão de vapor ou Brayton invertido. No caso do ciclo a ar, o ar fornecido é comprimido para manter a cabine pressurizada em condições adequadas de segurança e conforto.

\subsubsection{Sistema de proteção contra gelo}

A capacidade de uma aeronave voar em condições de tempo adversas é uma exigência para a maioria das aeronaves militares e comerciais. Formações de gelo em áreas críticas como borda de ataque das asas e empenagens podem afetar a segurança de voo, somando arrasto e peso, afetando adversamente assim a estabilidade. Gotas sub-resfriadas podem existir em nuvens a temperatura ambiente abaixo do ponto de congelamento. Quando as gotas são perturbadas por uma aeronave que voa através delas, as mesmas se chocam e podem congelar nas superfícies do avião em pontos de estagnação do escoamento, tais como aerofólios, nariz ou frente, entradas do motor, pára-brisas, e outras áreas, resultando em peso, arrasto e obstrução de visão dos pilotos nas superfícies transparentes. Por isso alguns meios devem prevenir formações de gelo em áreas críticas.

Dentre os sistemas de proteção contra gelo, o mais utilizado é o sistema de proteção a ar quente, principalmente devido à eficiência de remoção do gelo e confiabilidade. Nesse sistema, a injeção do ar quente extraído do compressor do motor é feita internamente às bordas de ataque das asas, nas entradas de ar dos motores e nas bordas de ataque dos estabilizadores, nestes últimos, nem sempre a proteção é necessária. A injeção de ar é feita por meio de um duto instalado internamente à superfície a ser protegida e que possui pequenos furos ao longo do mesmo para injeção de ar. A quantidade de ar insuflada é determinada assumindo evaporação completa de toda a água que incide sob a condição de formação de gelo mais severa que a aeronave possa encontrar. Outras partes do avião como tubos de Pitot, pára-brisas frontais, sensores de ângulo de ataque, tomadas de pressão estática, drenos de saída de água da aeronave, sensores de temperatura, entre outros, são protegidos contra formação de gelo por meio de aquecimento utilizando resistências elétricas. Com relação à chuva, a proteção pode ser feita com o uso de fluidos repelentes aplicados na superfície dos pára-brisas frontais, uso de limpadores elétricos e hidráulicos ou limpadores pneumáticos, nesse caso, jatos de ar quente sangrados dos motores são direcionados sobre a superfície externa do pára-brisa. 


\subsubsection{Sistema de atuação}

O sistema de atuação é potencializado hidraulicamente por meio de uma bomba conectada ao motor do avião por meio de uma caixa de engrenagens. A potência hidráulica de uma aeronave é suprida por dois sistemas independentes que fornecem pressão constante e vazão variável conforme as exigências de operação. O sistema de potência hidráulica é empregado para acionar o leme, ailerons, profundores, freios aerodinâmicos, superfícies de sustentação, trem de pouso, freios, atuadores do sistema de reversão da turbina, bem como sistemas auxiliares. A potência hidráulica é fornecida por conjuntos de bombas acionadas pelo motor da aeronave. Estas bombas estão conectadas a sistemas hidráulicos independentes, geralmente três por aeronave. Os demais componentes do sistema são: reservatório, indicadores de nível, comutadores térmico e de pressão, filtros, válvulas e tubulações. Em caso de falha do acionamento das bombas, bombas acionadas por motores elétricos suprem as demandas do sistema hidráulico.

O principio de funcionamento dos atuadores convencionais é baseado na modulação de uma fonte de pressão constante por meio de um atuador, o qual é comandado por um sinal elétrico dado pelo movimento dos comandos no manche por ação do piloto. A modulação da pressão é realizada pelo movimento de uma servo-válvula (Figura 1.4).

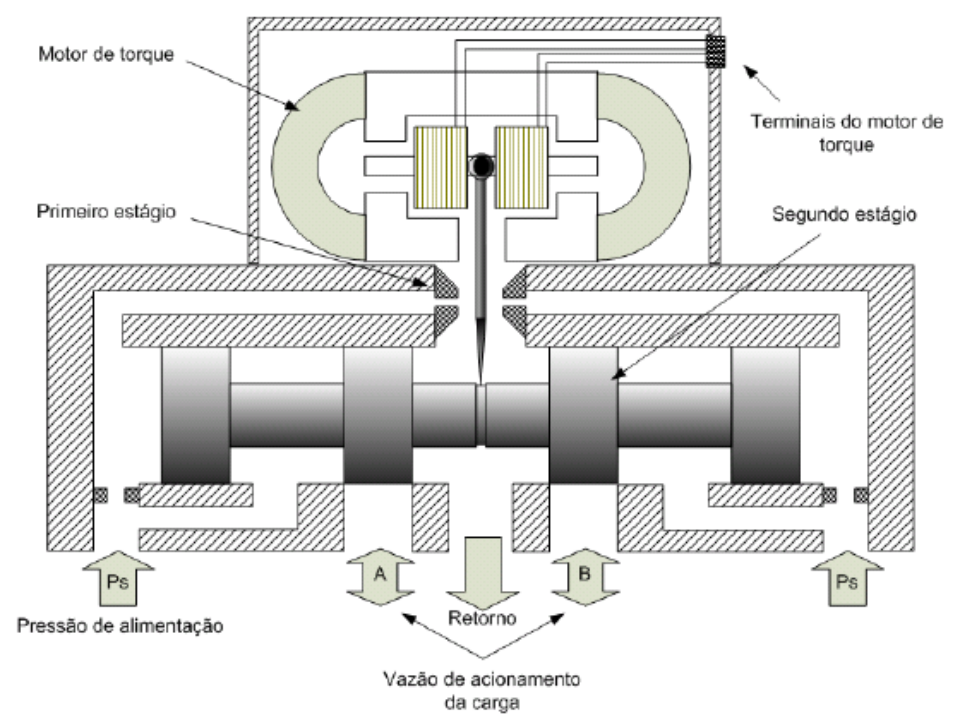

Figura 1.4: Servo-válvula eletro-hidráulica (MUSSI, 2008). 


\subsubsection{Sistema elétrico}

A função do sistema elétrico é fornecer energia elétrica para as cargas elétricas do avião. Deste modo, as duas funções importantes desempenhadas são a geração e a distribuição de energia elétrica.

Para garantir a qualidade da energia gerada e sua distribuição existem circuitos de controle dos alternadores (geradores), circuitos de partida de geradores, barras de alimentação, dispositivos de proteção, medição e acionamento.

Em aviões de pequeno porte é comum a utilização de geradores $\mathrm{CC}$, enquanto que em aviões de grande porte, geradores CA. Neste caso, são necessárias unidades retificadoras para converter energia CA em CC para alimentação de sistemas e cargas específicas.

No caso de aviões com geração de energia CA, os geradores são conectados diretamente às barras de alimentação. As baterias são conectadas diretamente às barras de cargas essenciais como iluminação de emergência, controle de voo, rádios de comunicação e navegação. Cargas não-essenciais como o aquecimento de alimentos e bebidas, iluminação comum e demais sistemas de conforto de cabine são geralmente desligadas no caso de falha de gerador e, portanto, ficam conectadas a barras diferentes daquelas essenciais.

No caso de falha de todos os geradores, as baterias alimentam os equipamentos essenciais, em geral, durante 20 a 30 minutos. Em aviões de grande porte é comum a utilização de um gerador eólico que é colocado fora do avião no caso de falha de todos os geradores, denominado turbina de ar de impacto.

O sistema elétrico tem geradores conectados ao motor da aeronave e da unidade de potência auxiliar. Normalmente os geradores são do tipo sem escova e controlados por unidades dedicadas. Os geradores do motor são conectados às barras de distribuição segregadas. O gerador da unidade de potência auxiliar, quando em operação, geralmente é conectado em paralelo aos geradores do motor. 
O sistema elétrico é projetado para satisfazer, quer em condições normais ou em condições de emergência, as cargas elétricas necessárias e essenciais, respectivamente, em cada fase do voo. Neste estudo, apenas as cargas elétricas em condições normais de operação e em cada fase do voo foram consideradas. 


\subsection{A aeronave com sistemas mais elétricos}

O estado-da-arte em arquiteturas de sistemas aeronáuticos é baseado em tecnologias complexas, bem conhecidas e sedimentadas pela indústria e utilizadas nas aeronaves de transporte civil, resultados de décadas de desenvolvimento e utilização.

A grande diferença energética entre o avião com sistemas convencionais e o avião com sistemas mais elétricos é a maior capacidade deste último em geração e distribuição elétrica, restringindo ou eliminando a geração de energia pneumática e hidráulica. Os sistemas que utilizavam potência pneumática, como ar condicionado e proteção contra gelo, e o sistema hidráulico, que na configuração convencional utiliza potência de eixo do motor para acionamento de bombas mecânicas, podem ter suas características de alimentação de potência alteradas. Devido à minimização das perdas nos processos de conversão de energia e ao controle ótimo do equipamento, o sistema de potência elétrica pode fornecer, aproximadamente, a demanda dos usuários em cada condição de operação. Dessa maneira pretende-se simultaneamente reduzir o consumo de potência, aumentar a eficiência de geração, melhorar o gerenciamento da potência disponível e aumentar a confiabilidade dos sistemas. Para tanto, uma maior geração elétrica é prevista, assim como a instalação de motores elétricos que exigem uma eletrônica de potência para controle e conversão da potência elétrica. A Tabela 1.1 mostra um breve comparativo entre o modelo energético convencional e uma possível alternativa mais elétrica.

Tabela 1.1: Tabela comparativa entre modelos energéticos.

\begin{tabular}{|c|c|c|}
\hline Sistema & Abordagem Convencional & Abordagem Totalmente Elétrica \\
\hline Motor & $\begin{array}{l}\text { Gera tração, potência de eixo e ar } \\
\text { comprimido para sangria. Partida do } \\
\text { motor é pneumática. }\end{array}$ & $\begin{array}{c}\text { Gera tração e potência de eixo. } \\
\text { Partida do motor é elétrica. }\end{array}$ \\
\hline $\begin{array}{c}\text { Unidade auxiliar } \\
\text { de potência }\end{array}$ & $\begin{array}{c}\text { Gera potência elétrica e ar } \\
\text { comprimido. }\end{array}$ & Gera apenas potência elétrica. \\
\hline $\begin{array}{c}\text { Potência } \\
\text { pneumática }\end{array}$ & $\begin{array}{l}\text { Gerada no motor (sangria de ar } \\
\text { comprimido) e distribuída para o } \\
\text { sistema de controle ambiental e }\end{array}$ & $\begin{array}{c}\text { Sem geração de potência } \\
\text { pneumática. }\end{array}$ \\
\hline
\end{tabular}




\begin{tabular}{|c|c|c|}
\hline Sistema & Abordagem Convencional & Abordagem Totalmente Elétrica \\
\hline \multicolumn{3}{|c|}{ proteção contra gelo } \\
\hline $\begin{array}{l}\text { Ar condicionado e } \\
\text { pressurização }\end{array}$ & $\begin{array}{l}\text { Pode utilizar máquinas de ciclo a ar } \\
\text { ou ciclo a vapor para refrigeração de } \\
\text { cabine. Ar comprimido do motor ou } \\
\text { da unidade auxiliar de potência é } \\
\text { usado para pressurização. }\end{array}$ & $\begin{array}{l}\text { Pode utilizar máquinas de ciclo a } \\
\text { ar ou ciclo a vapor para } \\
\text { refrigeração de cabine. O ar para } \\
\text { pressurização de cabine é } \\
\text { proveniente de compressores } \\
\text { acionados eletricamente. }\end{array}$ \\
\hline $\begin{array}{l}\text { Proteção contra } \\
\text { gelo nas } \\
\text { superfícies de } \\
\text { sustentação. }\end{array}$ & $\begin{array}{l}\text { Utiliza ar comprimido sangrado do } \\
\text { motor. }\end{array}$ & $\begin{array}{l}\text { Utiliza potência elétrica (eletro- } \\
\text { térmico, sistemas eletro- } \\
\text { expulsivos, sistemas eletro- } \\
\text { impulsivos). }\end{array}$ \\
\hline Potência hidráulica & $\begin{array}{l}\text { Gerada nos motores e distribuída por } \\
\text { todo o avião (trem de pouso, freios, } \\
\text { atuadores de superfícies de } \\
\text { comando, reverso, portas, etc). Um } \\
\text { grande número de linhas hidráulicas } \\
\text { é necessário. }\end{array}$ & $\begin{array}{l}\text { O trem de pouso é acionado } \\
\text { eletricamente ou possui geração } \\
\text { hidráulica local, por meio de } \\
\text { bombas elétricas. Os freios são } \\
\text { acionados eletricamente. Os } \\
\text { atuadores são acionados } \\
\text { eletricamente ou possuem geração } \\
\text { hidráulica local. }\end{array}$ \\
\hline
\end{tabular}

\subsubsection{Motor}

Em aeronaves com sistemas mais elétricos o motor é responsável apenas pela tração e pela potência elétrica. Não há mais extração de ar do motor para fins de ventilação e manutenção de temperatura da cabine. As potências pneumática e hidráulica também deixam de ser requeridas diretamente do eixo do motor e passam a ser fornecidas por compressores e bombas elétricas. Com essas alterações, o motor passa a fornecer apenas tração e potência de eixo para os geradores elétricos. Todas as outras demandas da aeronave são supridas por outros sistemas elétricos embarcados como bombas e compressores elétricos.

Dessa forma, apesar da eliminação de extração direta de potência de eixo para os sistemas hidráulicos e potência pneumática para o sistema extração pneumática, o motor do 
avião com sistemas mais elétricos deve ser capaz de suprir demandas elétricas muito maiores que o motor do avião com sistemas convencionais.

O motor para o avião com sistemas mais elétricos possui algumas diferenças chave com relação ao motor para o avião com sistemas convencionais (NEWMAN, 2004). A partida pneumática é substituída por partida elétrica por meio de um arranque-gerador montado diretamente no eixo do ventilador do motor. $\mathrm{O}$ arranque-gerador é uma máquina de relutância chaveada responsável pela partida elétrica e pela geração elétrica, quando operada no modo geração. Esta máquina pode operar em altas velocidades a possui maior eficiência que outros geradores. Com isto substitui-se a caixa de engrenagens encontrada na abordagem convencional.

As bombas que geralmente extraem potência de eixo da caixa de engrenagens são substituídas por bombas acionadas eletricamente. O funcionamento destas bombas pode ser otimizado, pois utilizam motores de freqüência variável. As principais diferenças entre um motor para a abordagem convencional e um motor para a abordagem mais elétrica podem ser visualizadas na Figura 1.5.

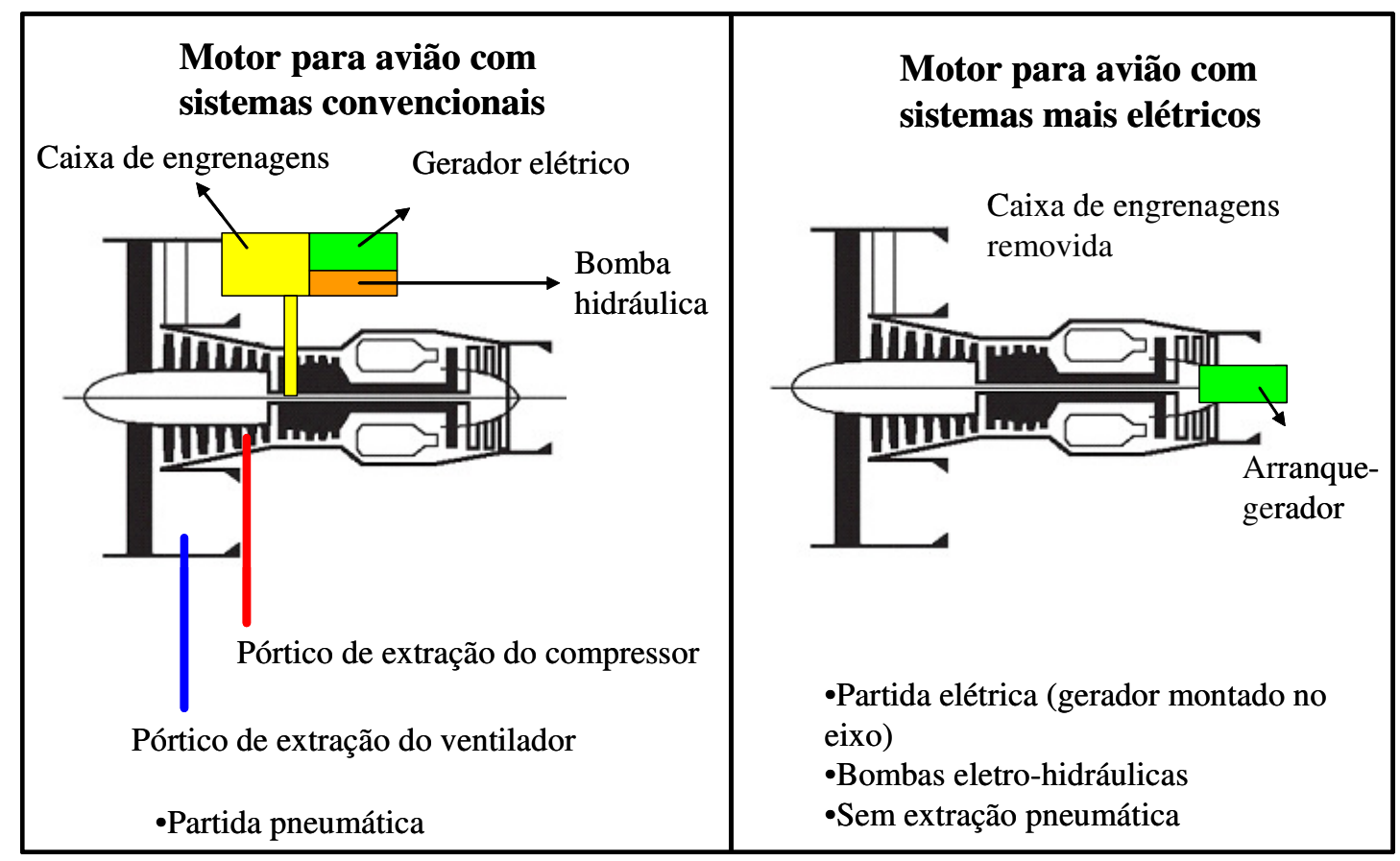

Figura 1.5: Principais diferenças com relação à extração de potência entre motores para avião com sistemas convencionais e sistemas mais elétricos. 
Um ganho importante com a configuração mais elétrica é a extensão da vida do motor, pois a extração de ar pode aumentar a temperatura do ar na entrada da turbina e perturbar o escoamento no interior do motor. Além disso, o motor para a abordagem mais elétrica pode ser projetado para atender a melhores condições requeridas (pressão na descarga do compressor e vazão de ar) para a reação de combustão, desempenho da turbina, potência de eixo e máximo empuxo, não exigindo a utilização do excesso de ar e valores de pressão para a operação do sistema de condicionamento de cabine e perdas no sistema pneumático.

\subsubsection{Sistema de ar condicionado}

Com relação ao sistema de ar condicionado mais elétrico, uma das opções é substituir a extração de ar comprimido dos motores por compressores de cabine acionados por motores elétricos. Nesse caso o ar condicionado é alimentado com ar comprimido oriundo de ar de impacto. $\mathrm{O}$ ar é direcionado aos compressores por meio de uma entrada de ar de alta eficiência na fuselagem. Após a compressão, o ar é direcionado para as máquinas de ar condicionado ciclo a ar que também estão presentes em arquiteturas convencionais, em seguida, o ar é direcionado para distribuição na cabine. Os compressores são acionados por motores elétricos que possuem rotação controlada, isto significa que a potência consumida pelos mesmos é feita sob demanda e de acordo com a necessidade do sistema. A Figura 1.6 mostra um esquema do sistema de ar condicionado mais elétrico ciclo a ar.

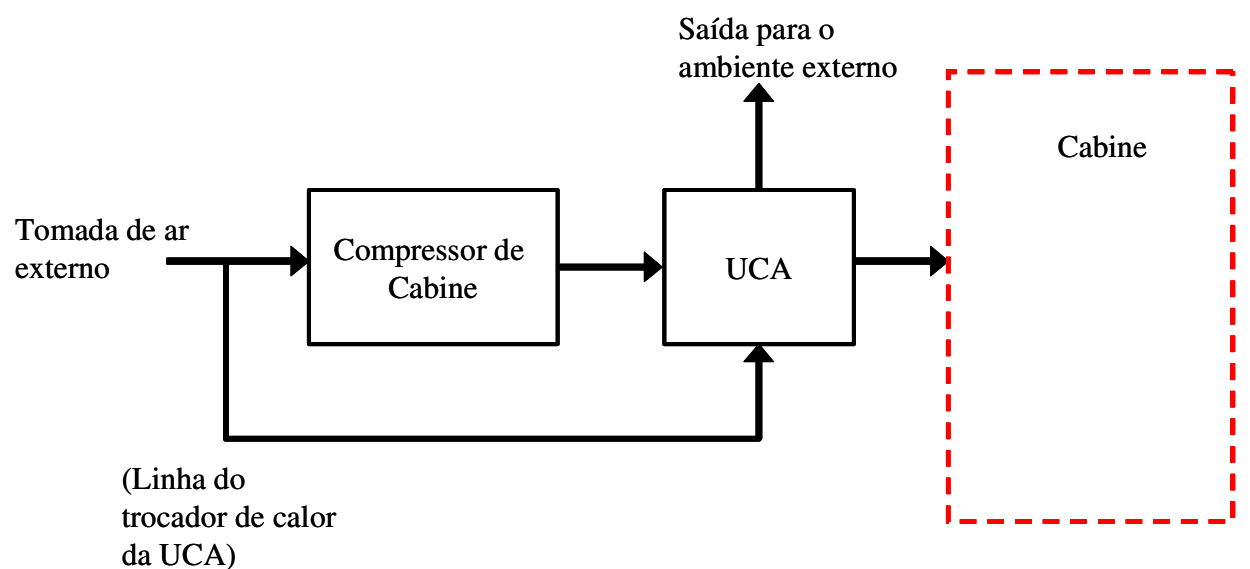

Figura 1.6: Sistema de ar condicionado mais elétrico com ciclo a ar. 
Outra arquitetura mais elétrica é a utilização de compressores de cabine junto com máquina de ciclo a vapor. Basicamente, a máquina de ar condicionado ciclo a ar é substituída por um ciclo a vapor que recircula parte do ar de cabine. O sistema é formado por compressores de cabine e pré-resfriador de calor utilizando fluxo de ar externo de impacto para resfriar o ar comprimido, conforme esquematizado na Figura 1.7.

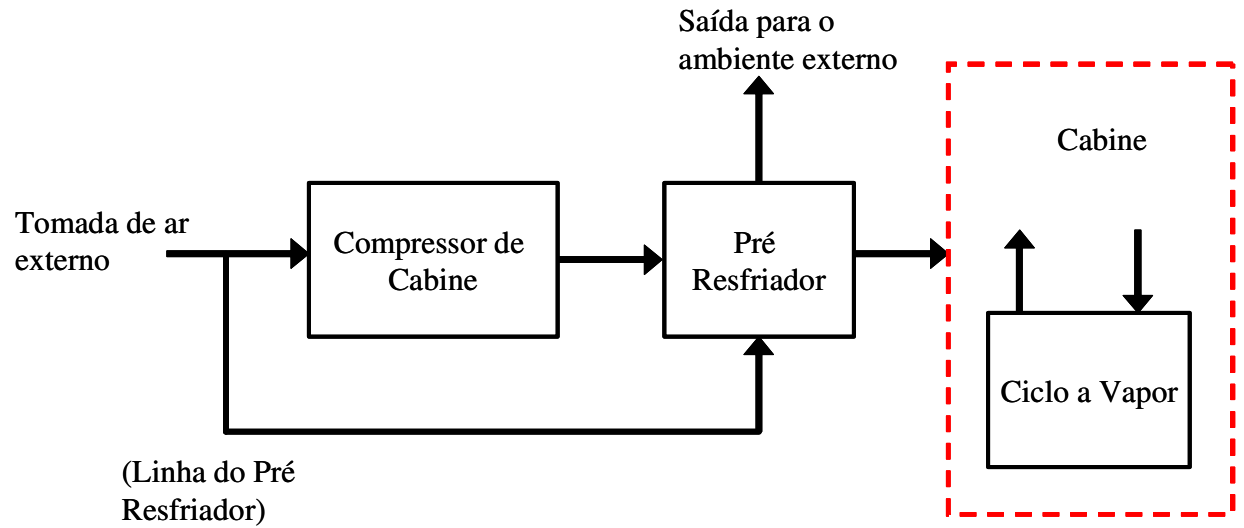

Figura 1.7: Sistema de ar condicionado mais elétrico com ciclo de compressão e vapor.

\subsubsection{Sistema de proteção contra gelo}

Há mais de uma solução de arquitetura de sistema de proteção contra gelo para o avião com sistemas mais elétricos. As duas principais arquiteturas são mencionadas nas seções 1.2.3.1 e 1.2.3.2.

\subsubsection{Sistema de proteção cíclico}

O sistema de proteção cíclico remove em períodos cíclicos pequenas formações de gelo. Nos sistemas apresentados anteriormente, o gelo é derretido utilizando uma alta taxa de calor, ou seja, a adesão do gelo na interface com o aerofólio é nula. Com o advento de sistemas trifásicos de corrente alternada para aplicações aeronáuticas, de baixo peso e freqüências típicas de 400 Hertz, os sistemas de resistências elétricas começaram a ser aplicados para proteção contra gelo. Estes sistemas eletro-térmicos foram primeiramente usados em superfícies de aerofólios ou em hélices de helicópteros nas quais outros meios de proteção são impraticáveis. O sistema eletro-térmico requer menor potência do que o sistema 
de proteção a ar quente devido à diferente estratégia de proteção. Os sistemas que utilizam ar quente são sistemas antigelo, enquanto que os sistemas eletro-térmicos podem ser classificados como antigelo ou degelo, dependendo da estratégia de funcionamento.

O aquecimento é feito por mantas de grafite montadas junto às bordas de ataque (Figura 1.8). As mantas são aquecidas rapidamente de modo que o gelo formado descole da superfície externa das bordas de ataque das superfícies de sustentação, sendo arrastado pelo fluxo de ar. Geralmente uma fileira de aquecedores são operados constantemente formando uma região de antigelo. Os outros painéis são estrategicamente localizados e são aquecidos em função do tempo e em locais distintos, a fim de minimizar o consumo de potência.

Nesses elementos pequenas superfícies de grafite são aquecidas rapidamente (por meio de efeito Joule) sem fundir. Esses painéis são estrategicamente localizados nas bordas de ataque das asas e estabilizador, podendo ser aquecidos em função do tempo em locais distintos a fim de minimizar o consumo de potência.

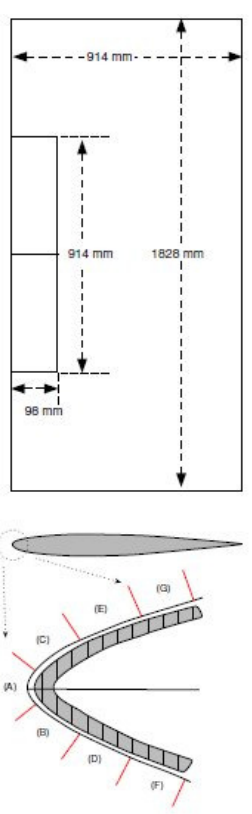

Figura 1.8: Aerofólio com aquecedores elétricos (AL-KHALIL 2001).

\subsubsection{Sistema de proteção eletro-expulsivo}


Uma corrente alta e com pequena duração passa por atuadores gerando campos magnéticos opostos que fazem com que os atuadores mudem de formato rapidamente (Figura 1.9 e Figura 1.10). Isto causa pequenas deformações na borda de ataque que fazem com que o gelo se desgrude. O peso é competitivo com outros tipos de proteção e os componentes são desenvolvidos para durar a vida da aeronave. A grande vantagem do sistema é o baixo consumo elétrico.

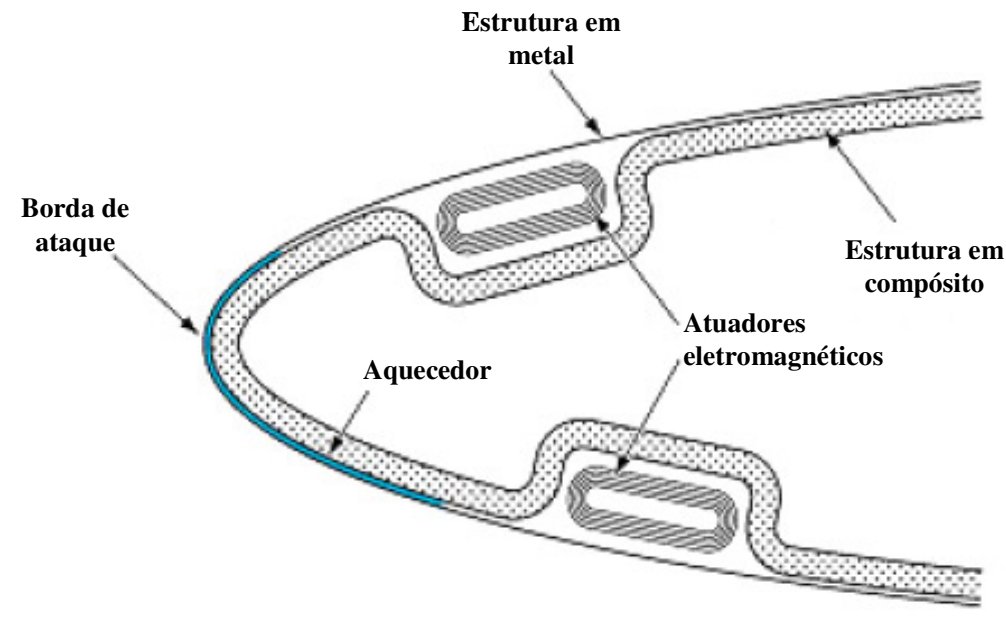

Figura 1.9: Sistema de proteção eletro-expulsivo (GORAJ, 2004).
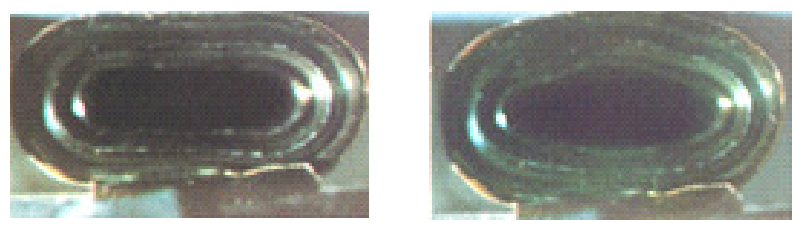

Figura 1.10: Atuador não deformado (esquerdo) e deformado (direito) (http://www.coxandco.com/aerospace/lowpower_ice_protection.html).

\subsubsection{Sistema de atuação}

A proposta do conceito de avião com sistemas mais elétricos é a de substituir pelo menos parte do sistema hidráulico por um sistema elétrico. A eliminação do sistema hidráulico pode acarretar importantes benefícios:

- Aumento da confiabilidade uma vez que os atuadores passam a ser independentes entre si; 
- Manutenção simplificada devido à eliminação da necessidade de se realizar a sangria de limpeza do fluido hidráulico, o que reduz o tempo da remoção e substituição das unidades com defeito;

- Possibilidade de se realizar um sistema de monitoramento de falhas dos atuadores uma vez que os mesmos são concentrados e possuem um controle eletrônico encapsulado.

Além disso, os atuadores mais elétricos podem ser designados como sensitivos à posição, o que significa que os atuadores irão gerar somente a força necessária para manter a superfície na posição requerida. Isso significa que os atuadores mais elétricos são mais eficientes uma vez que a potência gerada é equivalente à potência consumida, ao contrário dos sistemas hidráulicos, os quais necessitam manter um fluxo de fluido com pressão constante nas linhas o que gera perdas desnecessárias.

Os atuadores mais elétricos podem ser classificados em duas classes: atuadores eletromecânicos (AEM), os quais substituem a hidráulica por uma máquina elétrica, caixa de redução um mecanismo do tipo parafuso, e atuadores elétrico-hidrostáticos (AEH), os quais utilizam um conjunto motor-bomba-atuador para realizar a transformação da potência elétrica para hidráulica e em seguida para mecânica.

Como a transmissão de potência elétrica é realizada por meio de fios, o projeto e instalação de atuadores mais elétricos são mais fáceis do que o projeto e instalação de sistemas hidráulicos convencionais. Isto pode tornar o sistema de atuação mais leve visto que as tubulações hidráulicas são eliminadas.

\subsubsection{Atuadores eletro-hidrostáticos}

Com a função de transformar a energia elétrica em mecânica, ainda que mantendo a energia hidráulica como interface, os atuadores eletro-hidrostáticos (Figura 1.11), incorporam basicamente atuadores hidráulicos movidos por um motor elétrico local, um reservatório de fluido hidráulico e uma bomba hidráulica integrada, dispensando o uso do servo-atuador, uma vez que o controle de posição do atuador é realizado via controle do motor elétrico e de seu sentido de rotação conforme apresentado na Figura 1.12 . 


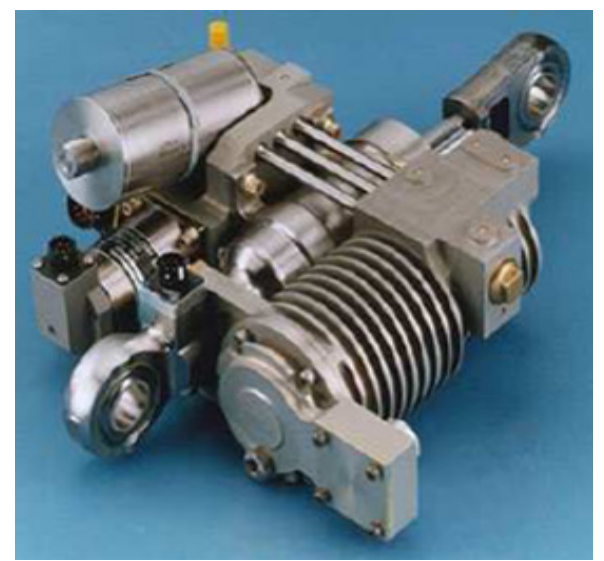

Figura 1.11: Atuador eletro-hidrostático (MIZIOKA, 2009).

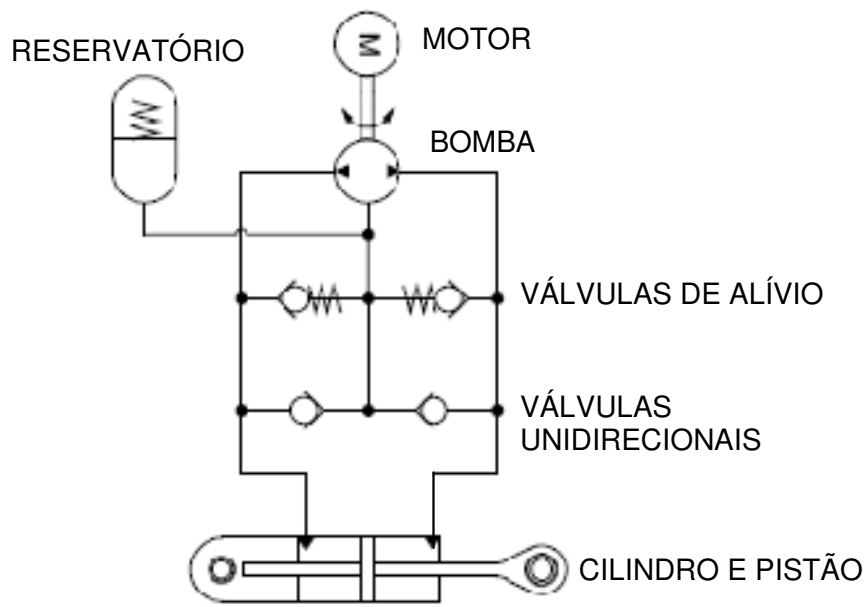

Figura 1.12: Esquema de atuador eletro-hidrostático (TAKEBAYASHI, 2004).

A aplicação destes atuadores não exige a presença de um sistema hidráulico centralizado por conter um reservatório local, permitindo eliminar as pesadas tubulações hidráulicas que aliviam o peso da aeronave e ainda reduzem os custos de manutenção. Por outro lado, a eliminação destas tubulações cria uma dificuldade ao atuador por não lhe permitir escoar o calor produzido pelo motor e pela bomba, anteriormente deslocado pelo fluido das tubulações.

No caso dos atuadores convencionais, as perdas térmicas são eliminadas pelo fluido, e na maioria do tempo a capacidade de troca de calor da tubulação é suficiente para manter a temperatura do sistema em nível aceitável. 


\subsubsection{Atuadores eletromecânicos}

O conceito dos atuadores eletromecânicos é transformar a energia elétrica em mecânica, especificamente o movimento rotacional em translacional, sem o auxílio da potência hidráulica.

Geralmente, estes atuadores consistem de um motor elétrico CC sem escovas ou de resistência chaveada. Uma eletrônica de potência deve ser implementada ao atuador, que transforma a energia elétrica e alguns dispositivos de transmissão mecânica, como caixa de engrenagens, parafuso ou cinemática de alavancas para operar o motor elétrico com razoáveis velocidades e torques (as forças atuantes na superfície de controle são relativamente altas frente às baixas velocidades) (MIZIOKA, 2009).

Na Figura 1.13 pode-se visualizar que, por meio da caixa de engrenagens, a rotação do motor é transmitida para o parafuso, estendendo ou recolhendo a haste.

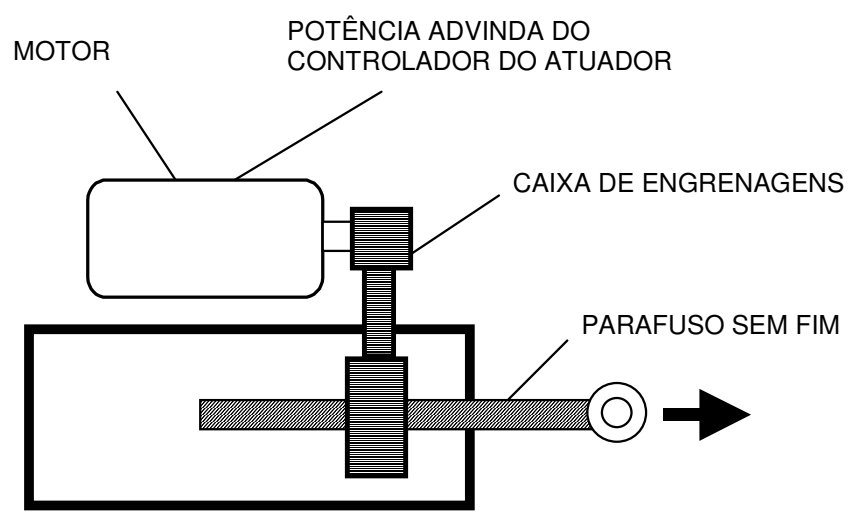

Figura 1.13: Esquema de atuador eletromecânico padrão com engrenagens e parafuso (MIZIOKA, 2009).

Existem outras configurações que não compreendem a instalação de caixa de engrenagens, como a movida diretamente ou a articulada, as quais proporcionam maior confiabilidade, redução de peso e o benefício de um sistema compacto. A configuração 
movida diretamente não requer caixa de engrenagens, usa-se o conceito do parafuso associado a outros parafusos para transmissão do movimento, conforme ilustrado na Figura 1.14.

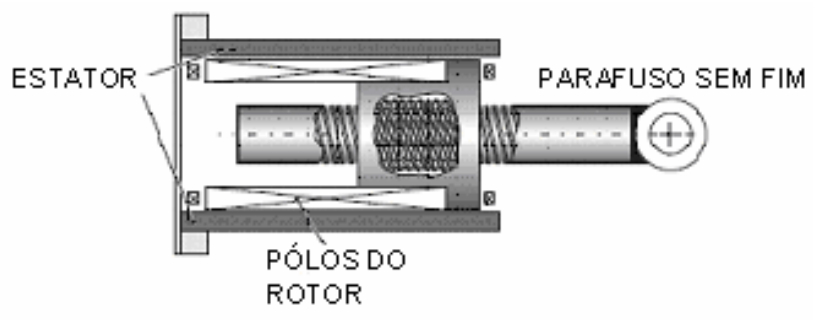

Figura 1.14: Esquema de atuador eletromecânico sem caixa de engrenagens (MIZIOKA, 2009).

A configuração articulada utiliza o mesmo conceito da configuração movida diretamente, mas em adição incorpora um sistema de alavancas para transmissão do movimento.

Com a tecnologia disponível atualmente, os fabricantes tendem a utilizar atuadores do tipo AEH ao invés dos AEM. Os principais motivos para esta escolha são:

- O uso da hidráulica como fonte de potências dos atuadores das superfícies primárias (profundor, leme e aileron) já é utilizada na maioria dos aviões comerciais;

- A hidráulica é uma fonte de potência amplamente conhecida e os fornecedores tradicionais já possuem um know-how e uma vasta coletânea de dados sobre o comportamento deste tipo de tecnologia;

- Os atuadores do tipo AEH são favorecidos pela possibilidade de se produzir um torque elevado mais rapidamente (resposta em freqüência mais rápida).

Contudo, os atuadores do tipo AEM possuem um grande potencial de desenvolvimento e, comparados com os $\mathrm{AEH}$, possuem as vantagens de serem mais leves, menores e mais simples.

\subsubsection{Sistema elétrico}

Os aviões com sistemas mais elétricos têm grande parte de seus acionamentos hidráulicos e pneumáticos substituídos por acionamentos elétricos, além de sistemas que substituem a forma da energia consumida originalmente por energia elétrica. Desta forma, a 
quantidade de energia solicitada ao gerador elétrico aumenta, incrementando as dimensões e complexidade do mesmo. Adicionalmente, são necessários novos dispositivos de interface. Por exemplo, conversores para acionamento de bombas elétricas; dispositivos de interface e controle para equipamentos eletromecânicos, além de equipamentos de proteção e monitoramento. Isso implica a preocupação com as redes de distribuição de energia, cabos de alimentação e estratégias de gerenciamento de cargas.

Como os geradores são maiores e pode ser necessária uma maior quantidade deles no avião, surgem novas tecnologias de geradores como os de freqüência variável, que são menores e mais econômicos, mas necessitam de dispositivos de conversão para garantir a qualidade da energia fornecida aos equipamentos do avião. Isso acontece por meio de conversores CA-CC, inversores, retificadores, entre outros.

Algumas mudanças conseqüentes da adoção de tecnologia mais elétrica merecem citação:

- Como os geradores são maiores, eles são montados no eixo do motor;

- Altas tensões, por exemplo, 350V em CC;

- Substituição das baterias convencionais por aquelas de íon-Lítio, pois estas têm maior capacidade de armazenamento de energia;

- Modificações na arquitetura do sistema elétrico, por meio de mais centrais de distribuição de energia elétrica, modificação nas cablagens e na própria distribuição de carga;

- Maior preocupação com estabilização de tensão, especialmente por causa das altas tensões $\mathrm{CC}$;

- Modelagem e simulação para ajustes de interface, características de equipamentos e estabilização do sistema de distribuição de energia elétrica

\subsection{Histórico sobre aeronaves com sistemas mais elétricos}

A aplicação de sistemas mais elétricos em aeronaves data desde a segunda guerra mundial. Nessa época, algumas aeronaves usavam potência elétrica para alimentar sistemas que usualmente hoje são alimentados por potência pneumática e hidráulica. Durante o mesmo período, outras aeronaves utilizavam potência pneumática e hidráulica para alimentar estes 
mesmos sistemas, começando assim o debate das vantagens e desvantagens sobre as diferentes formas de potência.

Após esse período, o tamanho e velocidade dos aviões começaram a crescer o que estimulou requisitos para potenciar funções como, por exemplo, comandos de voo. As três formas básicas de potência (pneumática, hidráulica e elétrica) encontradas nos aviões militares e civis de hoje começaram a evoluir. A hidráulica é usada para a maior parte das funções de atuação, pneumática para pressurização, ar condicionado e proteção contra gelo e elétrica para aviônica, iluminação, entretenimento de cabine, aquecimento de refeições, entre outras.

No final da década de 70 começaram a surgir algumas idéias e estudos sobre utilizar apenas potência elétrica. Estudos realizados pela Lockheed sobre materiais permanentemente magnéticos e dispositivos de potência elétricos incentivaram o conceito de se ter uma aeronave totalmente elétrica.

A universidade de Cranfield começou seus primeiros estudos em 1984, utilizando como plataforma de estudo o A300-600, com motores Rolls Royce RB211-524. Características como alterações na massa do avião, requisitos de potência secundária, aspectos de instalação, adoção de duas formas de sistemas de controle ambiental (compressor de cabine acionado diretamente no eixo do motor ou acionado eletricamente), proteção contra formação de gelo eletro impulsivo e partida elétrica dos motores foram consideradas. Como resultado do estudo, dois arranque-geradores de $180 \mathrm{kVA}$ cada deveriam ser instalados em cada motor.

No balanço de massa foi considerada principalmente a troca de equipamentos conforme abaixo:

- Sistema pneumático: retirada de dutos, vávulas, cablagens, trocadores de calor e inserção de compressores de cabine centrífugos, novas cablagens, sistema de arrefecimento para controladores e motores elétricos;

- Sistema de proteção contra gelo: retirada de dutos, válvulas, cablagens do sistema térmico e inserção do sistema eletro-impulsivo com novas cablagens e modificações estruturais das superfícies hiper-sustentadoras; 
- Sistema elétrico: retirada dos geradores originais e inserção de novos geradores com maior capacidade, conversores/controladores para os compressores de cabine, troca de cablagens, partida elétrica dos motores.

- Aspectos instalativos: mudança de massa na retirada da instalação dos equipamentos originais e inserção de instalação para os novos equipamentos.

A NASA patrocinou um estudo similar sobre as vantagens de um avião com potência secundária totalmente elétrica combinada com tecnologias de controle digital (IDEA "Integrated Digital Electrical Aircraft"), aplicados a aviões civis no ano de 1985. O estudo comparou um avião com sistemas convencionais contra um avião com sistemas mais elétricos equipado principalmente com tecnologia "fly-by-wire" com atuadores eletromecânicos, compressores de cabine acionados eletricamente, sistema de proteção contra gelo eletro impulsivo, geração elétrica em freqüência variável, partida elétrica dos motores. Como resultado o avião mais elétrico apresentou ganhos em consumo de combustível de cerca de 3\% para missões de 1000 milhas náuticas e mesma carga paga do avião convencional.

Os estudos realizados na década de 1980 mostraram que muitos equipamentos eram tecnicamente factíveis e havia ganhos em tornar o avião totalmente elétrico, entretanto, os riscos envolvidos nessa mudança tecnológica eram grandes em comparação com os ganhos, em se tratando de uma indústria conservadora. A partir de então, a indústria adotou a potência elétrica para as funções que mostravam vantagens, limitando assim os riscos e adquirindo experiência. Na década de 1990, os estudos e demonstrações em solo e em voo continuaram a acontecer como eletrônica de potência e projeto de máquinas elétricas (ex.: motores de relutância chaveada), o que levou ao avanço tecnológico dos dias atuais.

Atualmente o interesse nas tecnologias mais elétricas aumentou e alguns projetos já consideram essa abordagem. Na aviação militar, o F-35 (“Joint Strike Fighter" - JSF) é um programa que envolve algumas nações: Estados Unidos, Reino Unido, Holanda, Turquia, Canadá, Dinamarca, Noruega e Austrália. O projeto possui atuadores potenciados eletricamente, do tipo eletro-hidrostáticos.

Na aviação civil, o Airbus A380 adota o conceito do avião com sistemas mais elétricos ao utilizar atuadores eletro-hidráulicos. Devido ao uso de atuadores mais elétricos para os comandos de voo, associado ao aumento na demanda de energia elétrica de cabine, o A380 
necessita de uma geração de energia elétrica maior do que um avião do mesmo tamanho usando uma arquitetura convencional. Sendo assim, a Airbus resolveu adotar uma geração de energia elétrica com freqüência variável, o que permite aos projetistas eliminar os equipamentos necessários para converter a energia mecânica com frequiência variável em energia elétrica com freqüência constante, a qual é tradicionalmente usada em sistemas aeronáuticos.

A Boeing está introduzindo diversas inovações tecnológicas no desenvolvimento do Boeing 787. Além de utilizar asas e fuselagem de compósito e de adotar inovações na configuração da cabine, a Boeing considera este um projeto pioneiro em relação ao conceito do avião mais elétrico. Destacam-se como tecnologias mais elétricas adotadas:

- Geração de potencia elétrica em freqüência variável;

- Novas tecnologias elétricas de geradores, inversores e capacitores;

- Partida elétrica do motor com unidade auxiliar de potência toda elétrica e inversores;

- Motor sem sangria de ar comprimido;

- Ar condicionado com ciclo a ar de baixa pressão;

- Sistema de proteção contra gelo elétrico;

- Bombas hidráulicas acionadas por motores elétricos;

- Fontes hidráulicas perto dos sistemas usuários;

- Acionamento elétrico de superfícies de comando secundárias;

- Freios de comando e atuação elétricos. 


\section{Descrição da Necessidade}

A aviação comercial mundial está sofrendo cada vez mais pressão para se tornar mais lucrativa, evitando desperdícios e baixando custos operacionais. O cenário mundial de custos de combustíveis fósseis atingiu uma grande alta nos preços durante o ano de 2008 (Figura 2.1).

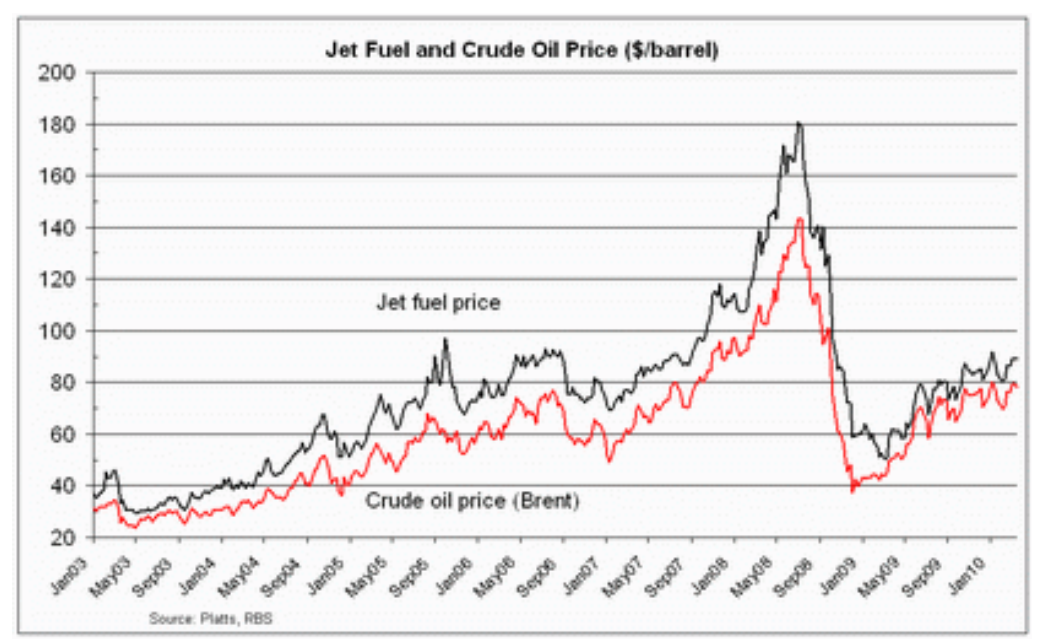

Figura 2.1: Variação do preço em dólares do barril de petróleo (linha vermelha) e combustível aeronáutico (linha preta) entre 2003 e 2009

(http://www.iata.org/whatwedo/economics/fuel_monitor/price_development.htm).

Apesar de o preço do barril de petróleo ter caído significativamente durante o ano de 2009 , fabricantes de aeronaves e seus fornecedores possuem metas de redução de consumo de combustível no desenvolvimento das futuras aeronaves. Tais metas, indicadas por pesquisas de mercado, apresentam reduções de no mínimo $15 \%$ de consumo de combustível e emissões de gás carbônico em relação a aeronaves atuais (BOEING, 2008). O Conselho Consultivo de Pesquisas Aeronáuticas na Europa prevê reduções nas emissões de gás carbônico para 2020 em até 50\% (EUROPA, 2001). Essas metas não são alcançáveis com as tecnologias de sistemas, materiais e motores disponíveis hoje. Pesquisas nas áreas de aerodinâmica, processos de fabricação com materiais mais leves, sistemas e motores são necessárias e estão em desenvolvimento. 
Nesse cenário, o avião com sistemas mais elétricos pode ser considerado uma alternativa e está em estudo por várias empresas e institutos de pesquisa com grande expectativa de redução de consumo de combustível. Existem vários programas de pesquisa e iniciativas da indústria relacionados a aviões com sistemas mais elétricos. Entre os mais significativos destacam-se:

\section{POA - "Power Optimized Aircraft":}

Com início em janeiro de 2002 e com duração de cinco anos, contou com a participação de 43 organizações do setor aeronáutico europeu entre indústrias, institutos de pesquisa e universidades. O projeto POA sofreu investimentos totalizando 100 milhões de Euros, financiados pelos participantes e pela própria comunidade européia. A LiebherrAerospace liderou o projeto, e os demais principais envolvidos são: Airbus, Alenia Aeronautica, Goodrich, Thales Avionics, Rolls Royce, Snecma Moteurs, Hispano-Suiza e German Aerospace Center. Como resultado, o projeto POA demonstrou que os sistemas mais elétricos são capazes de extrair 35\% menos potência do motor em cruzeiro do que os sistemas convencionais. Por outro lado, os sistemas mais elétricos possuem tendência a serem mais pesados que os convencionais, principalmente o sistema elétrico. Isto ocorre devido à alta estimativa de peso da eletrônica de potência que é utilizada no avião com sistemas mais elétricos. Entretanto, o estudo demonstrou que há possibilidade de se atingir $2 \%$ em economia de combustível (FALEIRO, 2006). Este valor é altamente dependente do tipo de missão, de acréscimos ao arrasto do avião devido a tomadas de ar externas para o ar condicionado mais elétrico e acréscimos em peso. O estudo também mostrou que há ganhos em manutenção para os sistemas mais elétricos, visto que são eliminadas linhas de ar comprimido e linhas hidráulicas que estão sujeitas a vazamentos.

\section{Boeing 787:}

A Boeing espera uma redução no consumo de combustível de aproximadamente $20 \%$ em relação às aeronaves atuais, devido a:

- melhorias aerodinâmicas: asa transônica avançada, otimização multidisciplinar com relação a peso, arrasto e desempenho de motor, redução de carenagens devido a melhor instalação compactada de sistemas, entre outros;

- novos conceitos de estruturas e materiais: fuselagem fabricada em material composto;

- motor sem extração de ar comprimido (Trent 1000 da Rolls Royce e Genx da GE, Figura 2.2); 
- utilização de arquiteturas de sistemas mais eficientes baseadas no conceito mais elétrico.
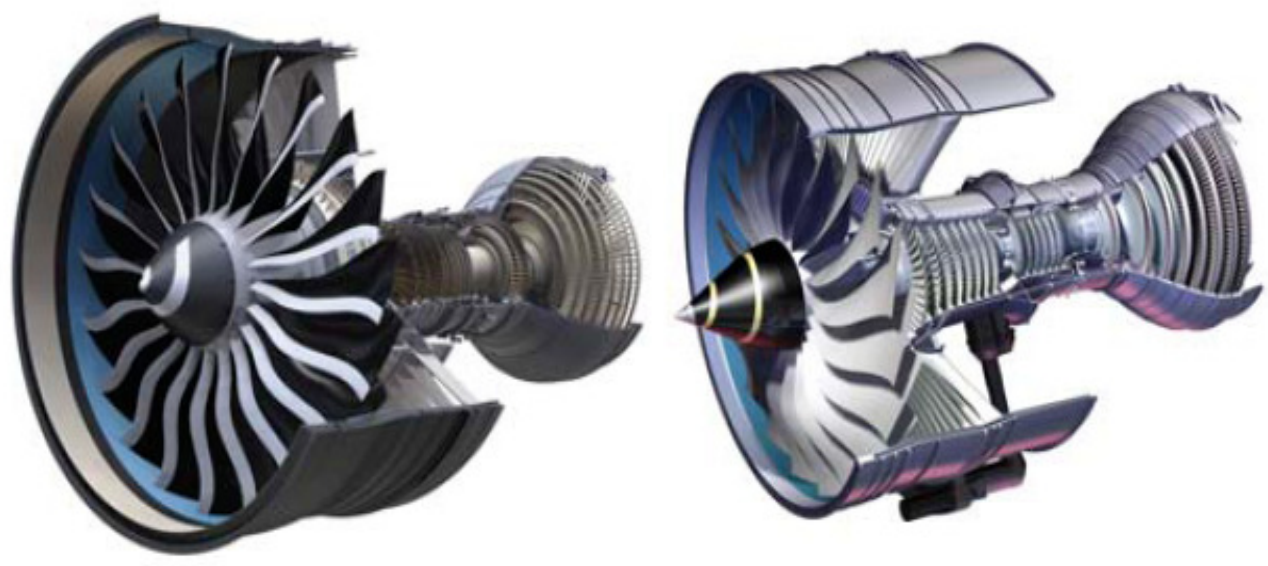

Figura 2.2: Rolls Royce Trent 1000 e GE Genx, ambos utilizam o conceito sem extração de ar comprimido (fontes: http://www.geae.com/, http://www.rolls-royce.com/civil/index.jsp ).

\section{Bombardier C-Series:}

Desenvolvimento anunciado pela Bombardier com redução de $15 \%$ no custo operacional em relação a aeronaves atuais e $20 \%$ em redução de consumo de combustível. Os avanços tecnológicos são: freios elétricos, utilização de tecnologia "fly-by-wire", materiais compósitos mais leves, novo motor Pratt\&Whitney PW1000G que possui tecnologia "geared fan" (faz com que o ventilador opere em velocidades mais lentas e otimizadas, reduzindo consumo de combustível).

Outras iniciativas de projetos de sistemas mais elétricos/mais eficientes:

- Pratt\&Whitney: pesquisa aplicada aos motores turbojatos para aviões com sistemas mais elétricos. Eliminação da caixa de engrenagens do motor, acoplamento de arranque-gerador sem escova no eixo de alta pressão;

- Liebherr: responsável pela liderança do projeto POA;

- Goodrich: participou do POA desenvolvendo sistemas de atuação (comandos de voo, trem de pouso e freios acionados eletricamente ou com geração local de energia hidráulica), desenvolvimento de sistemas de degelo eletro-térmico e mecânico de baixa potência elétrica; 
- Hamilton Sundstrand: participação no programa 787 da Boeing. Desenvolvimento de sistema de ar-condicionado para avião sem extração de ar do motor, desenvolvimento de sistemas de geração de potência elétrica para o Boeing 787;

- TIMES: "Totally Integrated More Electric Systems": programa patrocinado pelo Departamento de Comércio do Reino Unido;

- MEA: "More Electric Aircraft Program": US Air Force Research Laboratory. Desenvolvimento de tecnologia mais elétrica para a aviação militar;

- Hispano-Suiza: Participou do POA. Desenvolveu duas frentes: controle do motor e na distribuição de potência;

- Messier-Bugatti: Participou do POA. Trabalha com o projeto de freios elétricos;

- Snecma: Participou do POA, possui estudos na área de motores sem extração de ar comprimido;

- Honeywell: Desenvolve sistemas mais elétricos com soluções para unidade auxiliar de potência, unidade de controle ambiental, inversores de potência e outros sistemas.

Devido a este cenário atual da aviação mundial, surge a necessidade de analisar as novas tecnologias e arquiteturas de sistemas. Esta análise deve ser profunda o suficiente considerando aspectos energéticos, exergéticos e econômicos. Para tanto, a exergia é totalmente aplicada à esta necessidade visto que permite quantificar diferentes aspectos do projeto e desempenho de aeronaves em um mesmo padrão de avaliação e comparação. $\mathrm{O}$ uso combinado de índices aeronáuticos tradicionais, tais como combustível consumido, consumo específico de combustível e peso de decolagem, com parâmetros exergéticos de desempenho mostram-se de uso conveniente por permitirem uma análise global do desempenho da aeronave. Esta análise integrada permite a comparação de diferentes configurações auxiliando o engenheiro no processo de otimização e de entendimento de como ocorrem e se relacionam os processos de conversão de energia na aeronave. 


\section{Objetivo}

O objetivo principal deste trabalho é propor um método que utiliza a análise exergética para concepção e avaliação de sistemas aeronáuticos. O método é proposto para harmonizar o uso da exergia como ferramenta de decisão na concepção e avaliação de desempenho de sistemas aeronáuticos, assim como parâmetro de otimização. O método propõe índices que podem ser aplicados a todos os sistemas do avião, inclusive o motor.

Objetiva-se também utilizar este método para avaliar arquiteturas competitivas de sistemas de gerenciamento de ar mais elétrico frente aos sistemas convencionais aeronáuticos para uma mesma aeronave, e assim obter a real comparação em termos de qualidade de conversão de energia em nível sistema e impactos em nível avião.

A quantificação dos requisitos de dimensionamento e a apresentação da modelagem termodinâmica dos sistemas de gerenciamento de ar convencionais e mais elétricos, assim como a modelagem do motor para ambas as versões da aeronave, também são objetivos desta tese. 


\section{Revisão Bibliográfica: Análise Exergética na Indústria Aeroespacial}

A abordagem exergética vem sendo empregada há alguns anos para estudo de problemas de conversão de energia na indústria aeroespacial, principalmente em análises integradas de sistemas de aeronaves.

Alguns autores aplicaram a análise exergética aos sistemas de controle ambiental. Vargas e Bejan (2001) aplicaram a exergia como parâmetro de otimização de um trocador de calor do sistema de controle ambiental. A otimização baseou-se em maximizar a desempenho termodinâmico do avião (menor destruição de exergia ou consumo de combustível) variando a geometria do componente e analisando também a destruição de exergia no mesmo. Este trabalho mostra a importância da análise exergética em nível de sistemas e também em nível de avião. Em outro estudo de sistema de controle ambiental (ORDONEZ, BEJAN, 2003) são propostos procedimentos para a realização da otimização termodinâmica: limites realistas para menor potência requerida quando há operação reversível, assim como características de projeto que permitiriam a operação em condições de mínimo consumo de potência. É mostrado que a temperatura do fluxo de ar que a unidade de controle ambiental fornece à cabine pode ser otimizada para operação com mínima potência. Nesse trabalho, foram implementados modelos de transferência de calor no interior da cabine com diferentes graus de complexidade associados a um modelo de unidade de controle ambiental irreversível.

Paulus e Gaggioli (2000) defendem o uso da exergia para analisar sistemas complexos e que possuem diversas transformações energéticas, como uma aeronave. Os mesmos propuseram a avaliação dos fluxos exergéticos e exergia destruída após o projeto preliminar da aeronave, para identificação dos sistemas nos quais melhorias seriam mais benéficas para a aeronave. Para exemplificar, empregaram a análise exergética para realizar a análise de viabilidade de dois tipos de alternadores para um pequeno avião experimental. $\mathrm{O}$ método proposto utiliza a análise exergética assim como a análise termoeconômica para a seleção do alternador ótimo.

Muñoz (2000) desenvolveu várias estratégias de decomposição para otimização, aplicando-as à otimização integrada de dois subsistemas de um avião militar avançado e 
usando análise exergética como principal parâmetro. O autor defende que a análise exergética possibilita obter figuras mais completas dos processos de conversão de energia que ocorrem numa aeronave pois mostra a qualidade dos mesmos. Foi realizado o projeto conceitual de um turbo jato com pós-queimador e a síntese e otimização do projeto do ciclo a ar do sistema de controle ambiental. Na mesma linha de estratégias para otimização utilizando análise exergética, Rancruel (2002) aplicou o método desenvolvido por Muñoz (2000) para realizar a síntese, projeto e otimização operacional de um caça tático avançado. O avião foi decomposto em cinco subsistemas: propulsão, controle ambiental, circuito de combustível, ciclo de compressão de vapor, circuito de poli-alfa-olefina (PAO) e a estrutura do avião.

Figliola e colaboradores (2003) desenvolveram um modelo de unidade de controle ambiental para um avião militar que inclui sete subsistemas integrados: 1) o circuito de baixa temperatura de PAO; 2) o ciclo de compressão de vapor; 3) o ciclo a ar; 4) o circuito de alta temperatura de poli-alfa-olefina; 5) o circuito de óleo; 6) o sistema hidráulico e 7) o circuito de combustível. O modelo permite analisar cada subsistema, componente por componente, para cada requisito de missão do avião, ou de forma integrada ao longo da missão. O objetivo consiste em reduzir a geração de entropia total da aeronave, satisfazendo o desempenho requerido do sistema de controle ambiental e peso na decolagem (determinado por uma análise energética). As principais variáveis, tais como efetividade do evaporador, vazão mássica do circuito de baixa temperatura do PAO são expressas em função do peso na decolagem. A otimização foi realizada utilizando-se uma abordagem multi-objetivo aplicada a duas situações; mínimo peso de decolagem e mínima geração de entropia, tendo-se obtido resultados similares. O método mostrou que a análise exergética provê informações importantes para auxiliar o projeto de sistemas aeonáuticos.

Roth (2003) propõe um método de análise exergética e mostra a utilização da exergia durante uma missão de interceptação de um F5E, na região subsônica. Neste caso, 90\% da exergia total são destruídos no sistema de propulsão (combustão, exergia cinética e térmica dos gases de escape). Os $10 \%$ restantes são empregados para gerar o necessário empuxo requerido pelo avião. Além disso, o autor estabelece a ligação entre o desempenho aero termodinâmico e o peso do avião, sendo possível quantificar as perdas que ocorrem ao longo da missão (potência de arrasto, irreversibilidades do motor, etc.) em termos de massa de combustível requerida para compensar essas perdas em uma missão completa. Mostra-se que é possível fazer uma alocação do custo de combustível aos mecanismos de perdas 
aerotermodinâmicas durante uma missão completa de voo. O autor conclui que o uso da análise exergética provê a ponte entre as análises de desempenho e peso de aeronaves, e facilita a tomada de decisão em projetos de aeronaves.

Moorhouse (2003) propõe uma análise integrada e multidisciplinar para aeronaves usando a análise exergética como ferramenta para o projeto de toda a aeronave. O autor propõe um critério de alocação de perdas durante a missão quantificando os requisitos da missão em termos exergéticos em nível avião e descendo para nível sistema. O método proposto considera o trabalho necessário nas etapas de decolagem, subida, cruzeiro, descida, variações de massa e velocidade, etc. Este procedimento permite avaliar a exergia destruída em cada fase da missão.

Markell (2005) comparou um método baseado na análise exergética com um método tradicional quando aplicados à síntese/projeto e otimização operacional à configuração de um avião hipersônico considerando a estrutura aeronáutica e o sistema de propulsão (entrada, combustor e componentes do bocal). Os resultados obtidos com as otimizações mostraram que o método exergético tem bom desempenho quando comparado com o método padrão e, em alguns casos, conduz a melhores resultados ótimos de síntese/projeto em termos de requisitos de fluxo de massa de combustível para uma dada missão.

Butt (2005) aplicou métodos baseados na análise energética e exergética à síntese/projeto integrado de um caça ar-ar com e sem possibilidade de alterações na configuração das asas. As configurações do avião foram otimizadas empregando-se quatro funções objetivo distintas: mínimo consumo de combustível, mínima exergia total destruída e perdida, mínima exergia destruída e perdida pelo sistema de propulsão e maximização da eficiência de propulsão (tração). A minimização do consumo de combustível e da quantidade total de exergia destruída e perdida conduziu aos melhores resultados. Isto se deve ao fato de que ambas as funções objetivo visam, essencialmente, minimizar o uso da exergia do combustível do avião.

Periannan (2005) estudou funções objetivo baseadas na análise energética e exergética para a otimização de três subsistemas: propulsão, controle ambiental e configuração aerodinâmica do avião. $\mathrm{O}$ autor concluiu que a abordagem exergética, além de indicar onde 
ocorrem as maiores ineficiências, permite obter um veículo de desempenho superior que leva em conta as irreversibilidades em subsistemas.

Brewer (2006) aplicou a análise exergética à síntese/projeto de veículos hipersônicos genéricos nos quais os compromissos entre diferentes tecnologias são observados. Um veículo hipersônico foi projetado e otimizado para uma missão com três funções objetivo: máxima eficiência de propulsão (tração), mínimo consumo de combustível e mínima destruição de exergia e perda de exergia do combustível. As funções objetivo para mínimo consumo de combustível, mínima exergia destruída e perda de exergia do combustível mostraram-se aptas para o projeto e operação de um veículo que satisfaz as restrições da missão utilizando quantidades idênticas de combustível. A função objetivo que maximiza a eficiência da propulsão resulta em valores de combustível consumido e exergia destruída e perdida significativamente maiores.

Em resumo, muitos autores reconhecem que a análise de sistemas aeronáuticos deve ser um procedimento integrado em que se busca o objetivo de minimização de perdas ou melhoria de eficiência do veículo como um todo. Eles reconhecem também que a análise exergética aplicada a sistemas aeronáuticos traz benefícios singulares como a identificação dos equipamentos e processos de conversão de energia onde ocorrem as maiores ineficiências (exergia destruída). Como muitos autores já o fizeram, o parâmetro destruição de exergia pode ser usado em funções objetivo de diversos métodos de otimização.

Entretanto, nota-se que falta na literatura a especificação de um método dedicado e harmonizador, que consolide parâmetros já existentes e crie outros parâmetros comparativos entre sistemas para auxiliar a análise exergética aplicada a aeronaves. 


\section{Fundamentação Teórica}

\subsection{Processos reversíveis e irreversíveis}

Um processo reversível para um sistema é definido como aquele que, tendo ocorrido, pode ser invertido sem deixar vestígios no sistema e no meio. Ou seja, é reversível se, após ter ocorrido, os estados iniciais do sistema e seus arredores podem ser restaurados sem efeitos residuais em qualquer um deles. Já um processo irreversível é aquele que ao ser invertido deixa vestígios particularmente no meio. O processo reversível é um processo ideal, todos os processos reais são irreversíveis. Segundo Kotas (1985), o processo reversível embora seja uma idealização é conceitualmente útil, porque ele pode ser descrito mais facilmente em termos matemáticos do que um processo irreversível e, além disso, ele pode ser usado convenientemente como um padrão de perfeição para os processos reais.

Existem muitas causas que tornam o processo irreversível, chamadas irreversibilidades. Entre elas podem-se mencionar: atrito mecânico entre sólidos, aquecimento elétrico (Efeito Joule), perda de carga em escoamentos, troca de calor com gradiente de temperatura, misturas, reações químicas, difusão.

Um processo irreversível é acompanhado inevitavelmente de um aumento da entropia do universo (sistema e vizinhanças). Desta forma, o aumento da entropia pode servir como uma medida da imperfeição dos processos reais.

\subsection{Exergia}

Segundo Szargut (1988), a exergia é definida como a quantidade de trabalho obtida quando uma massa é trazida até um estado de equilíbrio termodinâmico com os componentes comuns do meio ambiente, por meio de processos reversíveis, envolvendo interação apenas com o meio ambiente. A exergia representa assim a máxima quantidade de trabalho que se pode obter de um fluxo energético, o que significa quantificar seu real valor termodinâmico.

Com a análise exergética é possível identificar a localização e as magnitudes das perdas exergéticas dentro de um processo ou sistema. A exergia é perdida ou consumida em 
todos os processos reais, tornando-se o recurso limitante para o funcionamento de todos os sistemas. Quando esta análise é aplicada aos processos de conversão de energia, caracteriza como a exergia do combustível é usada e destruída nestes processos, além disto, ela oferece as seguintes vantagens:

- usada como uma medida comum de entradas e saídas, possibilita o cálculo da eficiência exergética, a saber, a razão das saídas pelas entradas exergéticas totais. Esta razão fornece uma indicação do potencial teórico de futuras melhorias para um processo;

- o uso da análise exergética fornece uma medida comum da qualidade de conversão de energia para diferentes processos ou produtos, como acontece em aviões;

- outra vantagem está relacionada à definição da exergia, já que ela pode estimar a degradação da qualidade da energia dentro de um processo.

Segundo Szargut (1988), o principal propósito de uma análise exergética é descobrir as causas e estimar quantitativamente a magnitude da imperfeição dos processos de conversão de energia.

\subsection{Estado de referência}

Para possibilitar o cálculo da exergia de um sistema ou fluxo, é necessário definir uma referência que permita avaliar o máximo trabalho possível a ser realizado por um sistema. Essa referência é o meio ambiente. Considera-se meio ambiente a porção da vizinhança do sistema estudado cujas propriedades (pressão, temperatura e potencial químico) não se alteram significativamente ao interagir com o sistema.

$\mathrm{O}$ conceito de meio ambiente usado na análise exergética exige que ele esteja em estado de perfeito equilíbrio termodinâmico, ou seja, o meio deve ser homogêneo, não podendo possuir qualquer gradiente de pressão, temperatura, potencial químico, energias cinética e potencial. Embora o meio ambiente real seja complexo, procura-se, em geral modelá-lo como uma composição de substâncias existentes em abundância na atmosfera, oceanos e/ou crosta terrestre.

\subsection{Estado de referência restrito}


Segundo Kotas (1985), o estado de referência restrito é aquele onde as condições de equilíbrio térmico e mecânico entre o sistema e o ambiente são satisfeitas. Para que isto ocorra é necessário que as pressões e as temperaturas do sistema e o ambiente sejam iguais. $\mathrm{O}$ adjetivo restrito indica que, sob estas condições, as substâncias do sistema estão controladas por uma barreira física que evita a troca de matéria entre o sistema e o ambiente. Por isto não existe um equilíbrio químico entre o sistema e o ambiente.

\subsection{Estado morto}

Segundo Kotas (1985) o estado morto é definido como aquele onde as condições de equilíbrio térmico, mecânico e químico entre o sistema e o ambiente são satisfeitas. Assim, além das pressões e temperaturas, os potenciais químicos das substâncias do sistema e o ambiente devem ser iguais. Sob estas condições de equilíbrio termodinâmico total entre o sistema e o ambiente, o sistema não pode sofrer nenhuma mudança de estado por meio de alguma forma de interação com o ambiente.

5.6. Estado de referência restrito para análise de sistemas aeronáuticos

Uma aeronave passa por diferentes condições atmosféricas de temperatura e pressão ao realizar um voo e a escolha do ambiente de referência deve ser tratada de forma particular. A escolha do ambiente de referência para estudos de sistemas aeronáuticos já foi alvo de várias pesquisas. Basicamente existem duas abordagens do assunto:

- Temperatura e pressão fixas de acordo com as condições padrão em solo;

- Temperatura e pressão variáveis de acordo com as condições de voo (a referência é tomada pelas condições de estagnação ou instantâneas do ar que envolve a aeronave).

Roth (2000) realizou análises de sistemas propulsivos utilizando a Segunda Lei da Termodinâmica e análise exergética como figuras de mérito. $\mathrm{O}$ autor citou estudos que utilizaram a escolha da referência variável e indicou que a diferença entre as duas opções é de apenas $2 \%$ nos cálculos de exergia. O mesmo escolheu a referência variável como abordagem. 
Etele (2001) realizou uma análise de sensibilidade envolvendo um motor turbo jato entre o nível do mar e 15000 metros de altitude. Para realização dos cálculos de eficiência exergética do motor o mesmo comparou os resultados utilizando o ambiente de referência fixo em solo, ambiente de referência fixo a 15000 metros de altitude e ambiente de referência variável de acordo com as condições de estagnação nas altitudes simuladas. A variação máxima entre as três análises foi de $2 \%$.

Gogus (2002) analisou algumas aplicações nas quais o sistema está se movendo em relação ao ambiente e mostrou que a escolha de diferentes ambientes de referência pode causar diferenças consideráveis na análise. No caso de aplicações aeronáuticas, o mesmo defende que a escolha de diferentes ambientes de referência traz efeitos muito pequenos comparados com as mudanças de exergia envolvidas no sistema avião durante um voo. $\mathrm{O}$ autor defende o uso das condições de estagnação do ar que envolve a aeronave como referência.

Turgut (2006) realizou análise exergética de um motor turbo jato em duas condições de operação distintas: nível do mar e $11000 \mathrm{~m}$ de altitude. O autor também utilizou a referência na aeronave (nesse caso no motor), ou seja, as condições de estagnação do ar externo.

Em resumo, a utilização das condições de estagnação por altitude é a abordagem que contabiliza a exergia de forma mais representativa. O máximo potencial de trabalho está atrelado às condições ambientais que a aeronave realmente atravessa durante o voo, sendo que estas condições definem o reservatório térmico para aeronaves.

Obs.: as condições ambientes estáticas de temperatura e pressão da atmosfera foram calculadas neste trabalho utilizando o modelo de atmosfera padrão ("International Organization for Standardization”, 1975), publicado pela ICAO (“International Civil Aviation Organization").

\subsection{Componentes da exergia}


Desprezando efeitos pouco comuns na análise de processos como: os efeitos nucleares, magnéticos, elétricos e de tensão superficial, a exergia total de um sistema pode ser dividida em quatro componentes: exergia física, cinética, potencial e química.

$$
B=B_{f}+B_{c i n}+B_{p o t}+B_{q u i}
$$

Em base mássica:

$$
b=b_{f}+b_{\text {cin }}+b_{p o t}+b_{q u i}
$$

As energias cinética e potencial podem ser totalmente convertidas em trabalho, portanto correspondem às exergias cinética e potencial, como segue:

$$
B_{\text {cin }}=m \frac{v^{2}}{2} \text { e } \quad B_{p o t}=m g z
$$

Para um fluxo de massa, as exergias cinética e potencial podem ser definidas por:

$$
\dot{B}_{\text {cin }}=\dot{m} \frac{v^{2}}{2} \text { e } \quad \dot{B}_{p o t}=\dot{m} g z
$$

$\mathrm{Na}$ análise de sistemas estacionários, essas componentes geralmente têm valor zero ou são desprezíveis frente aos valores de h, e u. Entretanto, na análise de sistemas aeronáuticos, em que o sistema aeronave está se movendo com relação ao meio ambiente, considera-se apenas a parcela cinética em determinados fluxos de exergia, a parcela potencial pode ser desprezada conforme considerações feitas ao estado de referência descritas na seção 5.6.

A exergia física é igual à máxima quantidade de trabalho obtida quando um sistema ou fluxo de uma substância passa de um estado inicial ao estado de referência restrito. Para um sistema a exergia física é dada por: 


$$
B_{f}^{s}=B-B^{*}+p_{0}\left(V-V^{*}\right)-T_{0}\left(S-S^{*}\right)
$$

Em base mássica:

$$
b_{f}^{s}=b-b^{*}+p_{0}\left(v-v^{*}\right)-T_{0}\left(s-s^{*}\right)
$$

e para um fluxo:

$$
\dot{B}_{f}=\dot{m}\left(h-h^{*}-T_{0}\left(s-s^{*}\right)\right)
$$

Em base mássica:

$$
b_{f}=h-h^{*}-T_{0}\left(s-s^{*}\right)
$$

No cálculo da exergia física basta que o meio seja caracterizado pela pressão e a temperatura do estado de referência restrito $\left(p_{o}\right.$ e $\left.T_{o}\right)$.

A exergia química é igual à máxima quantidade de trabalho obtida quando um sistema ou fluxo é levado do estado de referência restrito ao estado morto. Para um sistema tem-se:

$$
B_{q u i}^{s}=U *+p_{0} V^{*}-T_{0} S *-\sum_{i=1}^{n} \mu_{0, i} N_{i}=\sum_{i=1}^{n}\left(\mu_{i}^{*}-\mu_{0, i}\right) N_{i}
$$

já para um fluxo em base molar tem-se:

$$
\bar{b}_{q u i}=\bar{h}^{*}-T_{0} \bar{s}^{*}-\sum_{i=1}^{n} \mu_{0, i} x_{i}
$$

A exergia química molar total de uma mistura composta por i espécies químicas se define como: 


$$
\bar{b}_{q u i}=\sum_{i}\left(\mu_{i}-\mu_{0, i}\right) n_{i}+R T_{0} \sum_{i} n_{i} \ln \left(a_{i}\right)
$$

A exergia total para um sistema é dada por:

$$
B^{s}=U+p_{0} V-T_{0} S-\sum_{i=1}^{n} \mu_{0, i} N_{i}
$$

e para um fluxo, a exergia específica é dada por:

$$
\bar{b}=\bar{h}-T_{0} \bar{s}-\sum_{i=1}^{n} \mu_{0, i} x_{i}
$$

\subsection{Balanço de exergia}

A análise exergética é uma aplicação sistemática da Primeira e Segunda Leis da Termodinâmica na avaliação do desempenho dos processos de conversão de energia, permitindo a efetiva avaliação termodinâmica dos processos, uma vez que quantifica as irreversibilidades que ocorrem durante o desenvolvimento destes processos.

O emprego combinado da Primeira e Segunda Leis da Termodinâmica permite que se estabeleça o balanço de exergia. Considerando-se o volume de controle mostrado na Figura 5.1 e desprezando as energias cinética e potencial, pode-se escrever os balanços de energia e entropia, para condições de regime permanente:

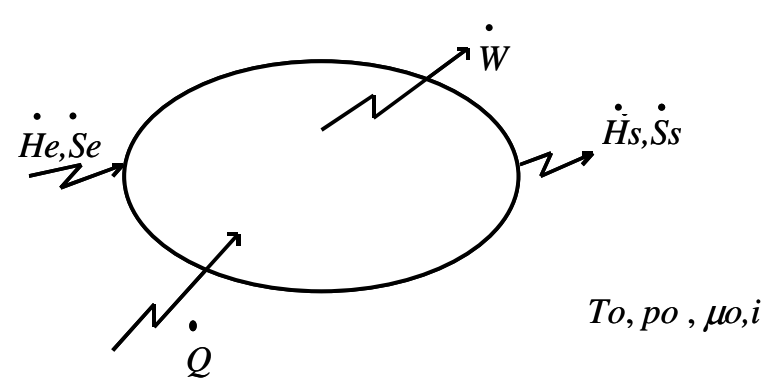

Figura 5.1: Volume de controle. 
Balanço de Energia:

$$
\dot{Q}-\dot{W}=\dot{H}_{s}-\dot{H}_{e}
$$

Balanço de Entropia:

$$
\frac{\dot{Q}}{T}+\dot{\sigma}=\dot{S}_{s}-\dot{S}_{e}
$$

Multiplicando-se a equação (15) por (- $\left.T_{o}\right)$ e somando à equação (14) tem-se:

$$
\dot{H}_{s}-\dot{H}_{e}-T_{o}\left(\dot{S}_{s}-\dot{S}_{e}\right)=\dot{Q}\left(1-\frac{T_{o}}{T}\right)-\dot{W}-T_{o} \dot{\sigma}
$$

A equação (16) é o balanço de exergia que quantifica a redução da capacidade de realização de trabalho, válido para o volume de controle considerado. Este balanço é formado pelos seguintes termos:

(variação de exergia entre os fluxos de entrada e saída $)=($ exergia associada ao calor trocado $)$ $+($ exergia pura $=$ trabalho realizado $)$ (exergia destruída $)$

A variação de exergia entre os fluxos de entrada e saída do volume de controle caracteriza o máximo trabalho que poderia ser obtido entre os estados de entrada e saída (trabalho reversível). Esta capacidade de realizar trabalho é igual à somatória composta pelas seguintes parcelas:

- trabalho que seria obtido de um motor térmico reversível operando entre os níveis de temperatura $T$ e $T_{o}$, consumindo $\dot{Q}$ e rejeitando calor para o meio ambiente à $T_{o}$ (este trabalho é a exergia associada ao calor trocado);

- trabalho efetivamente realizado (exergia pura); 
- trabalho disponível destruído devido à existência de processos irreversíveis (exergia destruída $\left.=T_{0} \dot{\sigma}\right)$.

Desta forma, é comprovado que a capacidade de realização de trabalho (exergia) não se conserva, sendo sempre reduzida toda vez que houver algum processo irreversível ocorrendo no volume de controle analisado.

As perdas exergéticas dos processos de conversão de energia podem ser divididas em duas partes, uma parte devida à destruição da exergia provocada pelas irreversibilidades do sistema; e a outra parte é a exergia perdida que é a exergia associada aos fluxos de material ou energia rejeitada ao ambiente. Dessa forma, considerou-se que a destruição de exergia total de cada sistema é a soma entre as irreversibilidades inerentes e os fluxos de exergia não úteis rejeitados ao ambiente.

\subsection{Rendimento ou eficiência exergética}

A eficiência exergética é definida como um parâmetro usado para avaliar o rendimento termodinâmico. A eficiência exergética (rendimento exergético, eficiência de segunda lei, efetividade, ou eficiência racional) fornece uma medida real do rendimento de um processo de conversão de energia do ponto de vista termodinâmico. Existem várias definições para a eficiência exergética, algumas delas são:

- Grau de Perfeição: denominada por Szargut (1988), é útil para avaliar processos químicos.

$$
\eta_{P}=\frac{\text { exergia dos produtos úteis }}{\text { exergia de alimentação }}
$$

- Rendimento/Eficácia exergética: indicada para analisar processos térmicos.

$$
\eta_{\text {ex1 }}=\frac{\text { exergia útil }}{\text { insumo de exergia }}
$$


A terceira expressão é indicada para avaliar processos em que há somente destruição de exergia, como expansão em uma válvula e rejeição de calor em um condensador, normalmente denominados processos puramente dissipativos:

$$
\eta_{e x 2}=\frac{\sum(\text { exergia de saída })}{\sum(\text { exergia de entrada })}
$$

Bejan, Tsatsaronis e Moran (1996) na definição da eficiência exergética, utilizaram os termos produto e combustível para identificar, respectivamente, o resultado desejado produzido por um sistema e os recursos gastos para gerar o produto. A eficiência exergética é dada pela razão entre a exergia do produto e a do combustível. Kotas (1985) definiu a eficiência exergética que chamou de "eficiência racional" em termos de produção desejada e alimentação necessária. 


\section{Método Exergético Para Concepção e Avaliação de Arquiteturas de Sistemas Aeronáuticos}

Este capítulo propõe um método usando a análise exergética como ferramenta para avaliar arquiteturas de sistemas de aeronaves comerciais. Esta análise permite a determinação da eficiência exergética e de outros índices de desempenho, taxas de exergia destruída e sua distribuição entre os sistemas do avião.

Os parâmetros de desempenho exergético usados neste trabalho permitem avaliar como a exergia do combustível é utilizada e destruída em cada um dos sistemas da aeronave, comparar desempenho de diferentes missões da aeronave, bem como distintas concepções de aeronaves. Dividiu-se em duas abordagens: uma para o avião convencional e outra para o avião mais elétrico, conforme ilustrado em capítulo anterior. Entretanto, deve-se salientar que o mesmo princípio de análise, aplicado a ambas as arquiteturas de sistemas, pode ser aplicado para comparar qualquer arquitetura competitiva de sistemas aeronáuticos.

O método exergético pode ser aplicado em diferentes fases do desenvolvimento de aeronaves: desde os estudos conceituais e ante projeto até a fase de definição da aeronave (Figura 6.1). Durante a fase de estudos conceituais e anteprojeto, os estudos de viabilidade técnica e econômica de um novo desenvolvimento são realizados. Ao longo desses estudos, são estabelecidos os requisitos gerais do avião como tipo de missão (tempo, velocidade, altitude, etc.), tipo de utilização (transporte de passageiros, transporte de carga, militar, etc.), as principais características geométricas do avião (diâmetro e comprimento da fuselagem, envergadura da asa e empenagens, área de referência da asa e empenagens, etc.), a escolha do motor (fabricante e modelo), são realizados os estudos estruturais e aerodinâmicos iniciais e inicia-se também o pré-dimensionamento dos sistemas, estabelecendo os principais requisitos de potência (potência de eixo, pneumática, hidráulica e elétrica). Durante a fase de ante projeto, iniciam-se os estudos de compromisso entre as diferentes configurações energéticas de sistemas (convencionais ou mais elétricos). A fase seguinte é marcada pela definição das arquiteturas de sistemas que ocorre entre fabricantes de aeronaves e sistemas, em nível de componente, sistema e aeronave. Nessa fase os sistemas são dimensionados e otimizados para o produto. O método exergético é aplicado desde os primeiros estudos de concepção 
energética dos sistemas até a fase de definição e otimização dos mesmos, sendo a exergia importante ferramenta de análise e otimização.

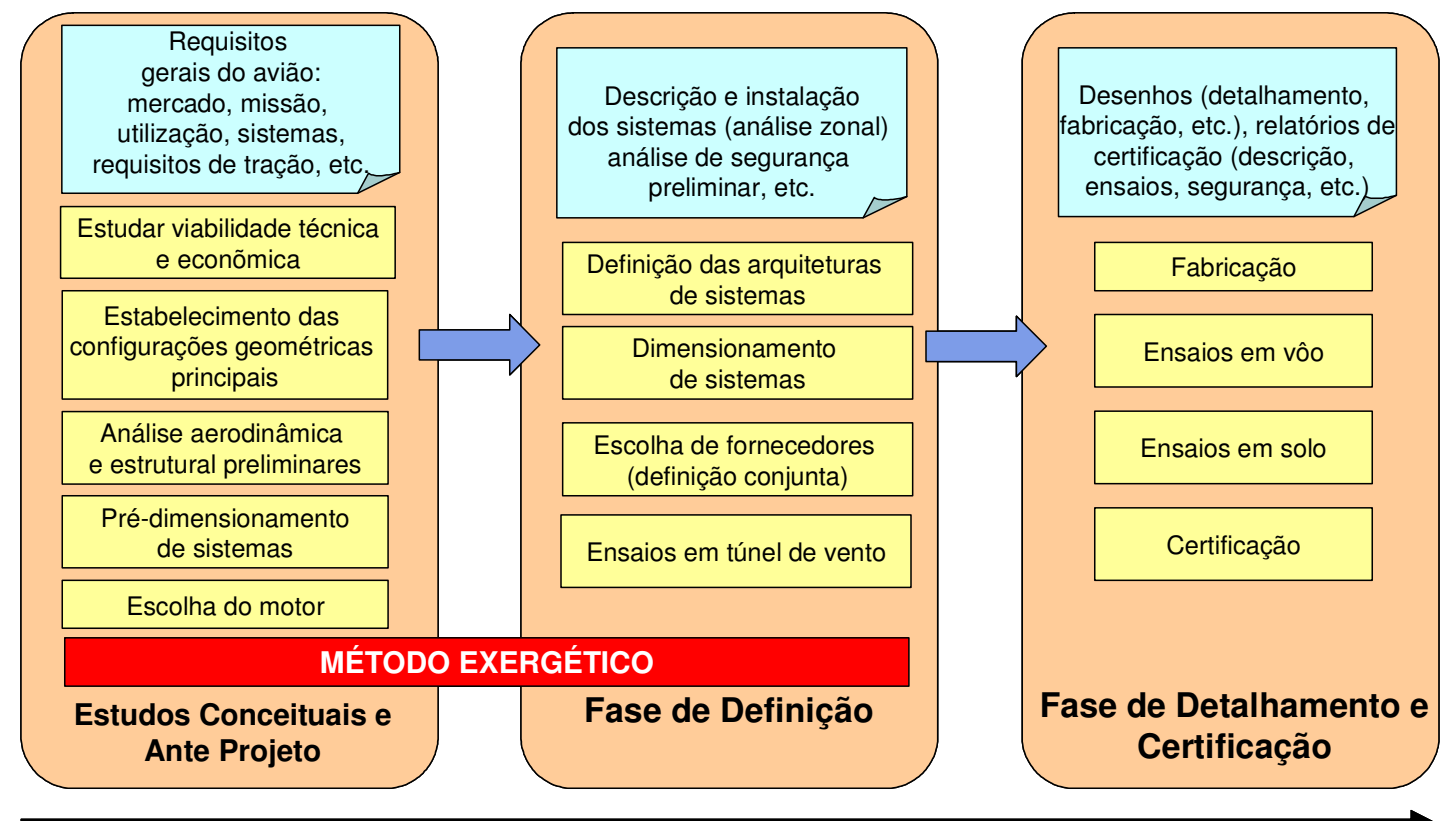

Desenvolvimento de produto

Figura 6.1: Método exergético no ciclo de desenvolvimento de aeronaves.

\subsection{Abordagem para o avião convencional}

Para fins de análise, o avião é dividido em oito sistemas: estrutura, motor, sistema de extração de ar (pneumático), elétrico, hidráulico e comandos de voo, antigelo, unidade de controle ambiental e cabine. A Figura 6.2 mostra os fluxos de entrada e saída de exergia para cada sistema considerado. As setas azuis representam fluxos de alimentação e efeitos úteis, enquanto que as vermelhas indicam fluxos de exergia perdida. A taxa de destruição de exergia em cada sistema é identificada dentro dos respectivos volumes de controle que representam cada sistema. A definição do rendimento exergético para a missão, que relaciona o efeito exergético útil pela exergia utilizada ao longo da missão (ar de entrada e combustível) é um parâmetro útil para comparar arquiteturas e projetos aeronáuticos para uma mesma missão. Além disso, a determinação de como a exergia do combustível é destruída nos sistemas do avião, assim como ao longo das fases do voo permite identificar as principais fontes e duração de irreversibilidades. 


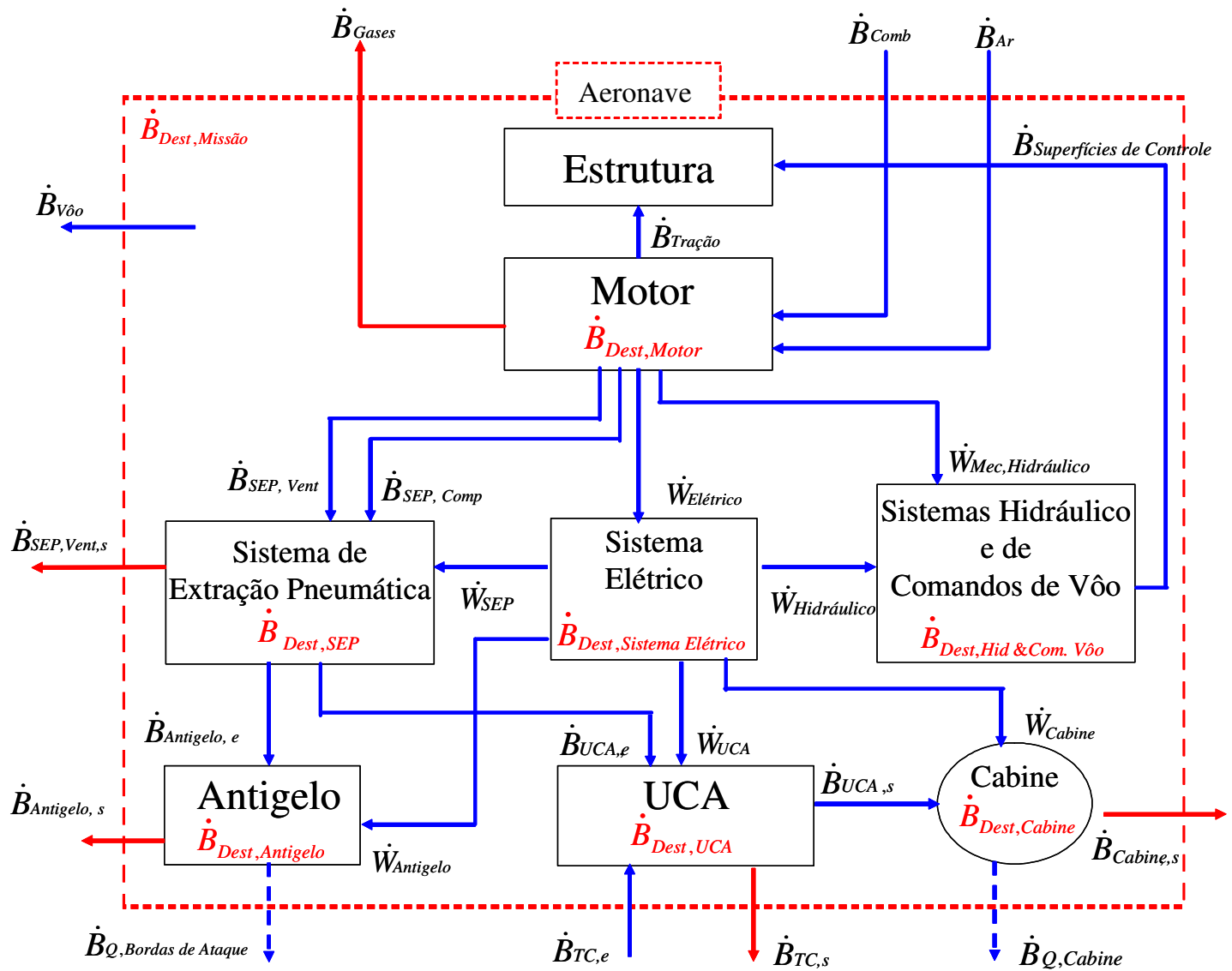

Figura 6.2: Demandas e penalidades impostas ao motor e à estrutura para uma aeronave convencional.

A análise exergética de toda a missão permite a determinação da taxa de exergia destruída, a eficiência exergética, assim como o consumo específico de exergia para cada sistema estudado e de toda a missão. As equações (20) a (36) apresentam as expressões dessas grandezas.

A destruição de exergia é provocada pela ocorrência de processos irreversíveis inerentes à operação de cada sistema. Já as perdas exergéticas estão associadas aos fluxos de exergia que deixam o sistema sem nenhuma utilização posterior. Nos sistemas aeronáuticos convencionais, as perdas de exergia estão relacionadas à exergia dos gases que deixam o motor, ao ar de impacto que deixa o trocador de calor da unidade de controle ambiental, ao ar extraído do ventilador do motor após passar pelo pré-resfriador (componente do sistema de extração pneumática) e ao ar que sai da cabine e vai para o meio ambiente. Como nenhum desses fluxos têm sua exergia utilizada, essas parcelas foram consideradas exergia destruída. Desta forma, as expressões das taxas de destruição de exergia para os sistemas analisados são mostradas nas equações (20) a (25). 


$$
\begin{gathered}
\dot{B}_{\text {Dest }, \text { Motor }}=\dot{B}_{\text {Comb }}+\dot{B}_{\text {Ar }}-\left(\dot{B}_{\text {Tração }}+\dot{B}_{\text {SEP,Comp }}+\dot{B}_{\text {SEP,Vent }}+\dot{W}_{\text {Elétrico }}+\dot{W}_{\text {Mec,Hidráulico }}\right) \\
\dot{B}_{\text {Dest }, \text { SEP }}=\dot{B}_{\text {SEP,Comp }}+\dot{B}_{S E P, \text { Vent }}+\dot{W}_{S E P}-\left(\dot{B}_{\text {Antigelo,e }}+\dot{B}_{U C A, e}\right) \\
\dot{B}_{\text {Dest }, U C A}=\dot{B}_{U C A, e}+\dot{B}_{T C, e}+\dot{W}_{U C A}-\left(\dot{B}_{U C A, s}\right) \\
\dot{B}_{\text {Dest }, \text { Antigelo }}=\dot{B}_{\text {Antigelo,e }}+\dot{W}_{\text {Antigelo }}-\left(\dot{B}_{Q, \text { Bordas_de_Ataque }}\right) \\
\dot{B}_{\text {Dest,Cabine }}=\dot{B}_{U C A, s}+\dot{W}_{\text {Cabine }}-\left(\dot{B}_{Q, \text { Cabine }}\right) \\
\dot{B}_{\text {Dest,Sistema_Elétrico }}=\dot{W}_{\text {Elétrico }}-\left(\dot{W}_{S E P}+\dot{W}_{U C A}+\dot{W}_{\text {Cabine }}+\dot{W}_{\text {Hidráulico }}+\dot{W}_{\text {Antigelo }}\right)
\end{gathered}
$$

As equações (26) a (30) apresentam as expressões da eficiência exergética dos sistemas analisados, considerando-se a razão entre o efeito exergético útil e a exergia utilizada em cada sistema. Pelo fato dos sistemas hidráulico e elétrico serem conversores essencialmente de potência em potência, não se considerou a eficiência exergética dos mesmos.

$$
\begin{gathered}
\eta_{\text {Motor }}=\left(\frac{\dot{B}_{\text {Tração }}+\dot{B}_{S E P, \text { Comp }}+\dot{B}_{S E P, \text { Vent }}+\dot{W}_{\text {Elétrico }}+\dot{W}_{\text {Mec,Hidráulico }}}{\dot{B}_{\text {Comb }}+\dot{B}_{\text {Ar }}}\right) \\
\eta_{S E P}=\left(\frac{\dot{B}_{U C A, e}+\dot{B}_{\text {Antigelo,e }}}{\dot{B}_{S E P, C o m p}+\dot{B}_{S E P, V e n t}+\dot{W}_{S E P}}\right) \\
\eta_{U C A}=\left(\frac{\dot{B}_{U C A, s}}{\dot{B}_{U C A, e}+\dot{B}_{T C, e}+\dot{W}_{U C A}}\right)
\end{gathered}
$$




$$
\begin{gathered}
\eta_{\text {Antigelo }}=\left(\frac{\dot{B}_{Q, \text { Bordas_de_Ataque }}}{\dot{B}_{\text {Antigelo,e }}+\dot{W}_{\text {Antigelo }}}\right) \\
\eta_{\text {Cabine }}=\left(\frac{\dot{B}_{Q, \text { Cabine }}}{\dot{B}_{U C A, s}+\dot{W}_{\text {Cabine }}}\right)
\end{gathered}
$$

O impacto da utilização da exergia em cada sistema no consumo de exergia associada ao combustível é determinado pelo cálculo do consumo específico de exergia (CEE). A utilidade dessa informação reside no fato de que se para um dado sistema o consumo específico de exergia é baixo, mesmo com um significativo aumento de seu rendimento exergético, o impacto no consumo de combustível será pequeno. As equações (31) a (36) mostram as expressões do CEE para os sistemas estudados.

$$
\begin{gathered}
C E E_{S E P}=\left(\dot{B}_{S E P, \text { Comp }}+\dot{B}_{S E P, \text { Vent }}+\dot{W}_{\text {Ext }}\right) / \dot{B}_{\text {Comb }} \\
C E E_{U C A}=\left(\dot{B}_{U C A, e}+\dot{B}_{T C, e}+\dot{W}_{U C A}\right) / \dot{B}_{\text {Comb }} \\
C E E_{\text {Antigelo }}=\left(\dot{B}_{\text {Antigelo,e }}+\dot{W}_{\text {Antigelo }}\right) / \dot{B}_{\text {Comb }} \\
C E E_{\text {Elétrico }}=\left(\dot{W}_{\text {Elétrico }}\right) / \dot{B}_{\text {Comb }} \\
C E E_{\text {Hidrúulico }}=\left(\dot{W}_{\text {Hidráulico }}+\dot{W}_{\text {Mec,Hidráulico }}\right) / \dot{B}_{\text {Comb }} \\
C E E_{\text {Cabine }}=\left(\dot{B}_{U C A, s}+\dot{W}_{\text {Cabine }}\right) / \dot{B}_{\text {Comb }} \\
C E E_{\text {Estrutura }}=\left(\dot{B}_{\text {Trą̧ão }}\right) / \dot{B}_{\text {Comb }}
\end{gathered}
$$


Apesar da estrutura não ser considerada parte dos sistemas, é importante calcular o CEE da mesma visto que a exergia relacionada à tração $B_{\text {Tração }}$ é um importante produto do motor.

A partir das taxas de destruição de exergia dos sistemas e duração de cada fase do voo, pode-se obter a exergia total destruída ao longo da missão.

$$
B_{\text {dest }, \text { missão }}=\sum_{\text {fases }}\left(\sum_{\text {sistema }} \dot{B}_{\text {dest, sistema }}\right) \cdot \Delta t_{\text {fase }}
$$

Uma vez determinada a exergia total destruída ao longo da missão, exergias totais relacionadas ao combustível e ao ar de admissão no motor, chega-se à eficiência exergética da missão.

$$
\eta_{\text {missão }}=1-\frac{B_{\text {dest }, \text { missão }}}{B_{\text {comb }}+B_{\text {entrada }}}
$$

\subsection{Abordagem para o avião mais elétrico}

O método aplicado ao avião mais elétrico é análogo ao avião convencional. Neste trabalho, a versão mais elétrica da aeronave é caracterizada pela eliminação do sistema de extração pneumática do motor e pelo sistema de antigelo evaporativo a ar quente. Tais sistemas são substituídos por sistema de ar condicionado mais elétrico com ciclo a ar; este com a instalação de compressores que direcionam o ar para a UCA; e sistema eletro-térmicos para degelo, conforme visualizado na Figura 6.3. Esta versão de um avião mais elétrico foi escolhida devido à alta demanda de potência do sistema de ar condicionado e do sistema de proteção contra gelo, sendo estes os maiores consumidores dentre os sistemas de aviões de transporte de passageiros. Analogamente ao avião convencional, as setas azuis representam fluxos de alimentação e efeitos úteis em cada sistema, as setas vermelhas indicam fluxos de exergia perdida e a destruição de exergia é identificada dentro da respectiva caixa que representa cada sistema. 


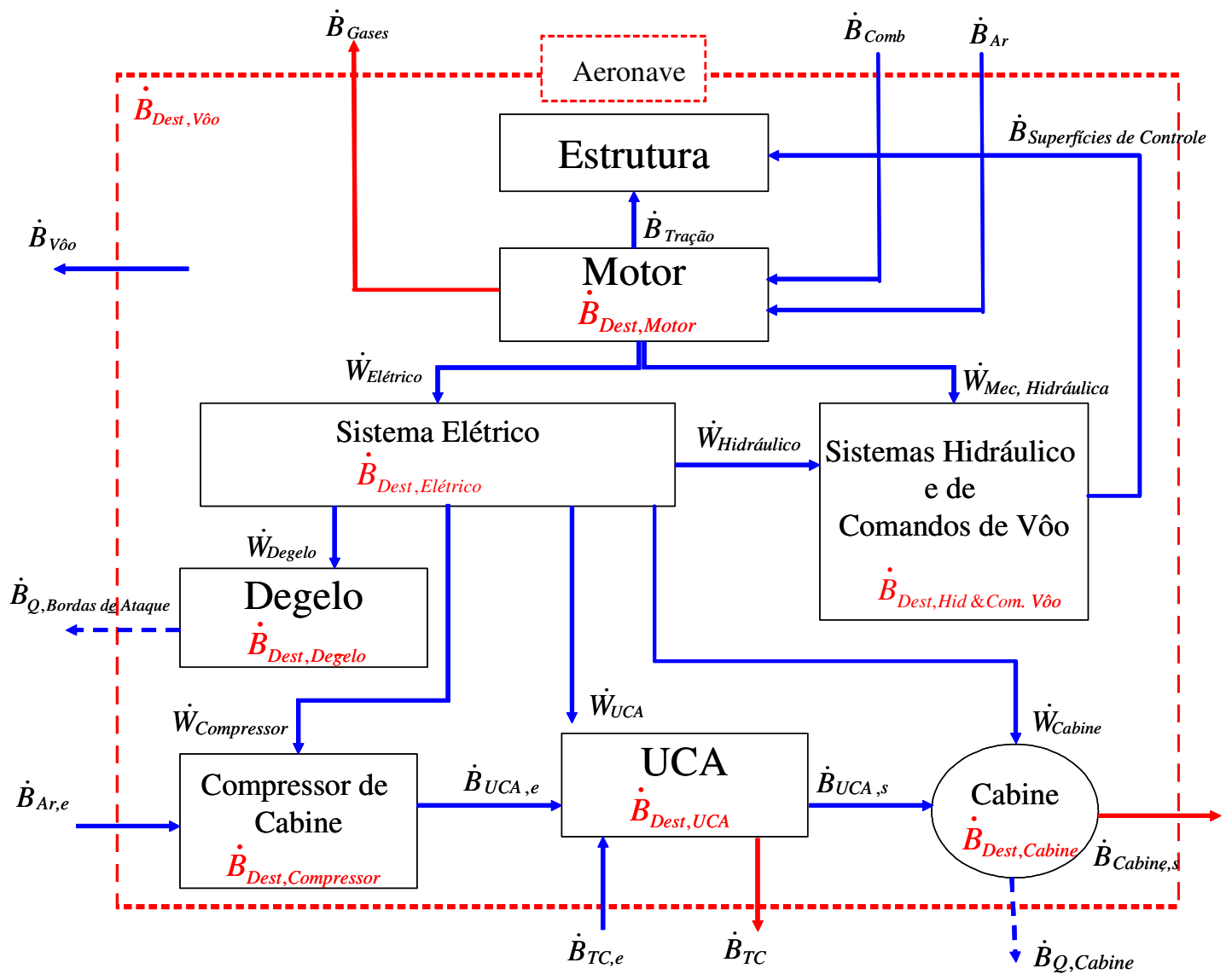

Figura 6.3: Demandas e penalidades impostas ao motor e à estrutura para uma aeronave mais elétrica.

As expressões de destruição de exergia para a UCA e cabine do avião mais elétrico são as mesmas consideradas para o avião convencional: equações (22) e (24), respectivamente. As taxas de destruição de exergia para o restante dos sistemas mais elétricos analisados são mostradas nas expressões a seguir:

$$
\begin{gathered}
\dot{B}_{\text {Dest,Motor }}=\dot{B}_{\text {Comb }}+\dot{B}_{A r}-\left(\dot{B}_{\text {Tração }}+\dot{W}_{\text {Elétrico }}+\dot{W}_{\text {Mec,Hidráulico }}\right) \\
\dot{B}_{\text {Dest,Compressor }}=\dot{B}_{\text {Ar,e }}+\dot{W}_{\text {compressor }}-\left(\dot{B}_{U C A, e}\right) \\
\dot{B}_{\text {Dest,_Degelo }}=\dot{W}_{\text {Degelo }}-\left(\dot{B}_{Q, \text { Bordas_de_Ataque }}\right) \\
\dot{B}_{\text {Dest,_Sistema_Elétrico }}=\dot{W}_{\text {Elétrico }}-\left(\dot{W}_{\text {Compressor }}+\dot{W}_{\text {UCA }}+\dot{W}_{\text {Cabine }}+\dot{W}_{\text {Hidráulico }}+\dot{W}_{\text {Degelo }}\right)
\end{gathered}
$$


As expressões de rendimento exergético para a UCA e cabine do avião mais elétrico são as mesmas consideradas para o avião convencional: equações (28) e (30), respectivamente. Os rendimentos exergéticos do motor, compressor e sistema de degelo são calculados por meio das seguintes expressões:

$$
\begin{gathered}
\eta_{\text {Motor }}=\left(\frac{\dot{B}_{\text {Trạ̧a } \tilde{o} o}+\dot{W}_{\text {Elétrico }}+\dot{W}_{\text {Mec }, \text { Hidráulico }}}{\dot{B}_{\text {Comb }}+\dot{B}_{\text {Ar }}}\right) \\
\eta_{\text {Compressor }}=\left(\frac{\dot{B}_{U C A, e}}{\dot{B}_{\text {Ar,e }}+\dot{W}_{\text {Compressor }}}\right) \\
\eta_{\text {Degelo }}=\left(\frac{\dot{B}_{Q, \text { Bordas_de_Ataque }}}{\dot{W}_{\text {Degelo }}}\right)
\end{gathered}
$$

As expressões de consumo específico de exergia para a UCA, sistema elétrico, hidráulico e cabine são as mesmas consideradas para o avião convencional: equações (32), (34), (35) e (36), respectivamente. Os consumos específicos de exergia para o compressor e sistema de degelo são calculados pelas seguintes expressões:

$$
\begin{gathered}
C E E_{\text {Compressor }}=\left(\dot{B}_{A r, e}+\dot{W}_{\text {Compressor }}\right) / \dot{B}_{\text {Comb }} \\
C E E_{\text {Degelo }}=\left(\dot{W}_{\text {Degelo }}\right) / \dot{B}_{\text {Comb }}
\end{gathered}
$$

As expressões de exergia destruída ao longo da missão e eficiência exergética da missão para o avião mais elétrico são as mesmas que foram consideradas para o avião convencional: equações (38) e (39), respectivamente. 


\section{Modelagem do Desempenho do Avião}

O desempenho de um avião está intimamente ligado com o movimento que o mesmo faz na atmosfera durante o voo. Este movimento é caracterizado pelo balanço de forças que agem no avião desde a decolagem, subida, voo nivelado e estabilizado (cruzeiro), descida e pouso. Detalhes muito específicos de aerodinâmica não são considerados, mas a mesma é representada pela polar de arrasto que condensa o balanço de forças que agem numa aeronave e que é utilizada para calcular os requisitos de tração em cada fase de voo.

Esta seção aborda os conceitos envolvidos na modelagem do desempenho e que resulta nos requisitos de tração para aeronaves. Os requisitos de tração são utilizados na confecção dos modelos de motor e no cálculo da exergia associada à tração.

\subsection{Equações gerais do movimento}

Um avião em movimento na atmosfera responde a quatro forças básicas do voo: sustentação, arrasto, tração e peso. A Figura 7.1 mostra duas situações típicas da configuração das forças durante um voo. Durante o voo nivelado, a força de sustentação (L) é igual à força peso (W) assim como a força arrasto (D) é igual à tração (T). Nesse mesmo caso o fluxo de ar move-se horizontalmente e é sempre na direção do voo $\left(V_{\infty}\right)$. A tração produzida pelo motor nem sempre aparece na mesma direção do fluxo de ar (vide ângulo $\varepsilon$ do lado esquerdo da Figura 7.1). Entretanto, durante um voo nivelado, pode-se considerar como simplificação que tração e arrasto estão na mesma direção. Uma outra situação típica é caracterizada por movimento de arfagem, ou seja, movimento sobre o eixo lateral da aeronave (linha imaginária que cruza o avião de uma extremidade à outra da asa), representado pelo ângulo $\theta$ na Figura 7.1. Outro movimento típico é o de rolagem, que é referente ao eixo longitudinal da aeronave (linha imaginária que cruza o avião de sua cauda à seu nariz), representado pelo ângulo $\varphi$ na mesma figura. $\mathrm{O}$ arrasto é paralelo e o peso é perpendicular à velocidade de voo $V_{\infty}$. 


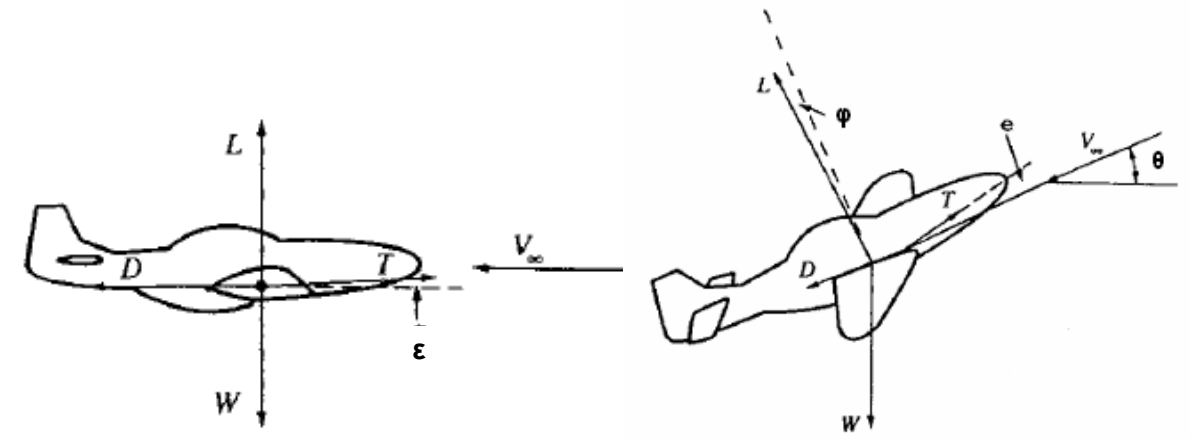

Figura 7.1: As quatro forças do voo, voo nivelado horizontal (esquerda) e voo em subida com rolagem (direita) (ANDERSON, 1999).

As equações de movimento para um avião podem ser demonstradas a partir da segunda Lei de Newton:

$$
F=m a
$$

Como simplificação e para efeito de estudo, não são considerados efeitos de curvatura da Terra e variações da gravidade. As equações do movimento são (ANDERSON, 1999):

- na direção do voo:

$$
m \frac{d V_{\infty}}{d t}=T \cos (\varepsilon)-D-W \operatorname{sen}(\theta)
$$

- na direção perpendicular ao voo, em relação ao plano vertical:

$$
m \frac{V_{\infty}{ }^{2}}{r_{1}}=L \cos (\varphi)+T \operatorname{sen}(\varepsilon) \cos (\varphi)-W \cos (\theta)
$$

- na direção perpendicular ao voo, em relação ao plano horizontal:

$$
m \frac{\left(V_{\infty} \cos (\theta)\right)^{2}}{r_{2}}=L \operatorname{sen}(\varphi)+T \operatorname{sen}(\varepsilon) \operatorname{sen}(\varphi)
$$


As Equações (50) a (52) descrevem o movimento translacional de uma aeronave através do espaço tridimensional sobre a Terra sem efeitos de curvatura e sem considerar efeitos de derrapagem da aeronave (i.e., a velocidade $V_{\infty}$ é considerada sempre paralela ao eixo de simetria do avião). Tais considerações são suficientes para este trabalho.

\subsection{Polar de arrasto}

Conforme já conhecido da Mecânica dos Fluidos, as características aerodinâmicas de um corpo podem ser descritas pelos seus coeficientes aerodinâmicos de sustentação $\left(C_{L}\right)$, arrasto $\left(C_{D}\right)$ e momento $\left(C_{M}\right)$ conforme abaixo:

$$
\begin{gathered}
C_{L}=\frac{L}{q_{\infty} S} \\
C_{D}=\frac{D}{q_{\infty} S} \\
C_{M}=\frac{M}{q_{\infty} S c}
\end{gathered}
$$

Sendo $q_{\infty}$ a pressão dinâmica definida como $q_{\infty}=\frac{1}{2} \rho V_{\infty}{ }^{2}, S$ é uma área de referência arbitrária (para uma aeronave é conveniente definir como sendo a área de referência da asa, ou área "planificada" da asa por ser de mais fácil cálculo) e c é uma característica de comprimento do corpo (ex.: para um aerofólio $c$ é definido como o comprimento da corda).

Os coeficientes aerodinâmicos são levantados em ensaios de túnel de vento utilizando um modelo em menor escala do corpo envolvido. Os ensaios são realizados variando a velocidade do fluxo (número de Mach) e o ângulo de ataque do modelo. Os coeficientes levantados em túnel representam as características aerodinâmicas do corpo de grande escala. 
Há apenas duas fontes para as forças resultantes num corpo imerso num fluido: a distribuição de pressão e tensões de cisalhamento do fluido que atua sobre o corpo. Conseqüentemente, com relação ao arrasto, há apenas duas formas básicas de arrasto que agem num corpo (ANDERSON, 1999): arrasto de pressão (componente de força resultante da distribuição de pressão atuando na superfície do corpo) e arrasto de atrito (componente de força devido aos efeitos viscosos do fluido).

Considerando o regime de voo subsônico, que é o regime abordado neste trabalho, o arrasto sobre um corpo é resultante da soma entre o arrasto de atrito $\left(C_{F}\right)$ e o arrasto de pressão $\left(C_{P}\right)$. O arrasto de atrito é a parcela resultante da viscosidade do ar que atua na superfície de um corpo. $\mathrm{O}$ arrasto de pressão (ou arrasto de forma) é causado pela diferença da distribuição de pressão sobre um corpo na direção do arrasto, quando há separação da camada limite.

$$
C_{D}=C_{F}+C_{P}
$$

$\mathrm{O}$ arrasto pode ser dividido em algumas categorias para todo o avião que contribuem para identificar o arrasto total:

- Arrasto de atrito: arrasto devido aos efeitos viscosos integrado em toda a superfície de um corpo;

- Arrasto de pressão: arrasto devido à diferença da distribuição de pressão sobre um corpo na direção do arrasto, devido à descolamento da camada limite;

- Arrasto de forma: soma do arrasto de atrito e do arrasto de pressão para um corpo (termo geralmente usado para aerofólios);

- Arrasto de interferência: arrasto de pressão causado devido à interação mútua dos escoamentos ao redor de todos os componentes do avião. $\mathrm{O}$ arrasto total do avião é geralmente maior do que a soma do arrasto dos diversos componentes (asa, fuselagem, empenagens, antenas, motor, etc.). A diferença é o arrasto de interferência;

- Arrasto parasita: termo usado para o arrasto de forma integrado à toda superfície da aeronave, incluindo o arrasto de interferência;

- Arrasto induzido: arrasto de pressão devido ao fluxo induzido pelos vórtices criados nas pontas das asas finitas; 
- Arrasto referente à sustentação zero: é o arrasto parasita quando a aeronave não possui sustentação;

- Arrasto devido à sustentação: mudança no arrasto parasita quando a aeronave está numa configuração de ângulo de ataque diferente de quando ela não possui sustentação, somado ao arrasto induzido das asas e de outros componentes de sustentação;

- Arrasto de onda: aparece quando há aparecimento de ondas de choque em escoamentos supersônicos. A presença de ondas de choque criam uma configuração de distribuição de pressão ao redor do corpo que causam fortes diferenças de pressão na direção do arrasto. A integração dessa distribuição de pressão dá origem ao arrasto de onda.

Para qualquer corpo aerodinâmico, a relação entre o coeficiente de arrasto $\left(C_{D}\right)$ e o coeficiente de sustentação $\left(C_{L}\right)$ pode ser expressa por uma equação e/ou mostrada num gráfico. Esta relação entre os dois coeficientes é denominada polar de arrasto, que resume toda a aerodinâmica da aeronave. Sendo assim, toda a informação necessária para realizar uma análise de desempenho de uma aeronave está contida na polar de arrasto, visto que a mesma relaciona sustentação com arrasto.

Utilizando os conceitos apresentados anteriormente, pode-se escrever que o coeficiente de arrasto resulta (ANDERSON, 1999):

$$
C_{D}=C_{D, e}+C_{D, w}+k_{1} C_{L}^{2}
$$

Sendo $C_{D, e}$ a parcela do arrasto parasita, que é a soma entre o arrasto referente à sustentação zero $C_{D, e, 0} \mathrm{e}$ o incremento parasita devido à sustentação $\Delta C_{D, e}$. Quando há variação no ângulo de ataque para gerar a sustentação, ocorrem alterações nos arrastos de atrito e pressão, cuja soma é refletida no termo $\Delta C_{D, e}$. O termo $C_{D, w}$ representa a parcela referente ao arrasto de onda, que pode ser analisada conforme os mesmos princípios da parcela do arrasto parasita. $\mathrm{O}$ termo $k C_{L}^{2}$ refere-se ao coeficiente de sustentação, que reflete a 
relação quadrática entre $C_{D}$ e $C_{L}$ conforme é observado nos comportamentos aerodinâmicos de aerofólios (ANDERSON, 1999). Pode-se escrever então:

$$
\begin{gathered}
C_{D, e}=C_{D, e, 0}+\Delta C_{D, e}=C_{D, e, 0}+k_{2} C_{L}^{2} \\
C_{D, w}=C_{D, w, 0}+\Delta C_{D, w}=C_{D, w, 0}+k_{3} C_{L}^{2}
\end{gathered}
$$

Utilizando as equações (57), (58) e (59), pode-se escrever as seguintes relações:

$$
\begin{gathered}
C_{D}=C_{D, e, 0}+C_{D, w, 0}+k_{1} C_{L}^{2}+k_{2} C_{L}^{2}+k_{3} C_{L}^{2} \\
C_{D, 0}=C_{D, e, 0}+C_{D, w, 0} \\
K=k_{1}+k_{2}+k_{3}
\end{gathered}
$$

Que resulta na polar de arrasto do avião:

$$
C_{D}=C_{D, 0}+K C_{L}^{2}
$$

7.3. Voo nivelado e estabilizado

O voo nivelado e estabilizado (Figura 7.2) é uma condição particular das equações gerais de movimento de um avião. O voo nivelado é caracterizado pelos ângulos de arfagem $(\theta)$ e rolagem $(\varphi)$ iguais a zero e sem acelerações. A partir das equações (50) e (51), colocamse os termos $\theta, \varphi, \frac{d V_{\infty}}{d t}, \frac{V_{\infty}^{2}}{r_{1}}$ iguais a zero (sendo o raio $\mathrm{r}_{1}$ infinitamente grande para o voo 
em uma linha reta). Isto resulta no seguinte balanço de forças para o voo nivelado e estabilizado, desconsiderando o ângulo $\varepsilon$ (i.e., tração alinhada com arrasto):

$$
T=D
$$

$$
L=W
$$

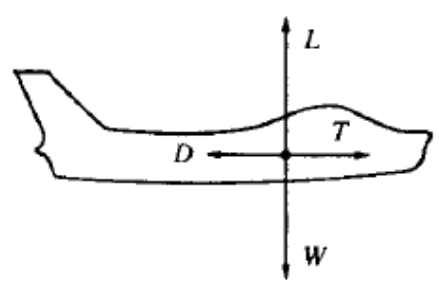

Figura 7.2: Diagrama de forças para o voo nivelado e estabilizado (ANDERSON, 1999).

Neste trabalho, considerou-se voo nivelado e estabilizado nas situações de cruzeiro espera (situação de espera para pouso, i.e., cruzeiro a uma altitude adequada acima do aeroporto).

\subsection{Decolagem e pouso}

A decolagem é um processo no qual a velocidade do avião varia a cada instante. A decolagem pode ser dividida em algumas etapas de acordo com a velocidade atingida, em ordem crescente:

- velocidade de "stall”: velocidade que o avião obtém a mínima sustentação;

- velocidade mínima de controle no solo: velocidade que a empenagem vertical consegue controlar o avião caso haja uma falha de motor durante a decolagem;

- velocidade mínima de controle no ar: velocidade ligeiramente maior que a velocidade mínima de controle no solo;

- velocidade de decisão: velocidade em que se pode continuar a decolagem mesmo com uma falha de motor. Este é o ponto máximo em que o piloto ainda pode abortar a decolagem. Se uma falha de motor ocorrer quando o avião 
atingir uma velocidade maior que a velocidade de decisão, a decolagem deve ser continuada;

- velocidade de decolagem: velocidade que o piloto pode acionar a empenagem horizontal e obter taxa de subida suficiente para a decolagem.

A Figura 7.3 apresenta as forças que agem no avião durante os processos de decolagem e pouso:

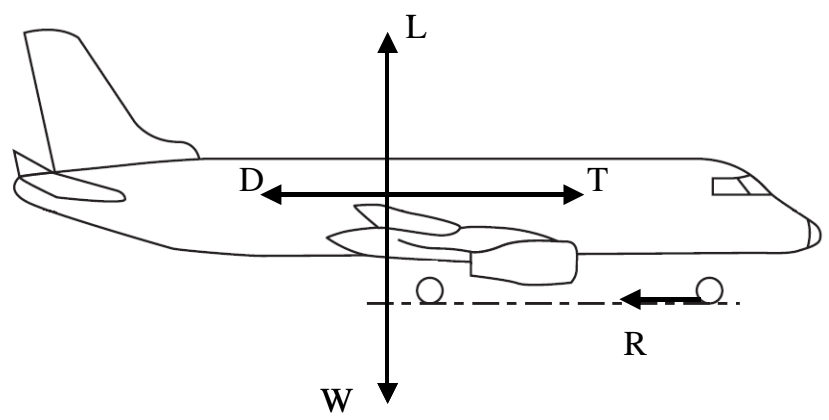

Figura 7.3: Forças que agem num avião durante o pouso e a decolagem.

O balanço de forças durante as operações de pouso e decolagem pode ser escrito conforme segue:

$$
m \frac{d V_{\infty}}{d t}=T-D-R
$$

Sendo a força $R$ igual à somatória das forças de atrito que agem nos pneus, dada por:

$$
R=\mu_{R}(W-L)
$$

$\mu_{R} \quad$ : coeficiente de atrito entre pneus e solo

$W-L$ : força normal entre pneus e solo 
Durante os processos de pouso e decolagem, a polar de arrasto deve contabilizar os efeitos das superfícies aerodinâmicas que são defletidas para aumento de sustentação ("flaps" e "slats") e freios aerodinâmicos para o pouso ("ground spoilers"). A extensão do trem de pouso também causa modificações no arrasto e também deve ser contabilizada na polar de arrasto. Devido à proximidade com o solo, o arrasto induzido sofre modificações que são denominadas de efeito solo. Nesse caso, a sustentação da asa é modificada junto com o arrasto induzido causado pela mesma.

\subsection{Subida e descida estabilizadas}

A subida e descida estabilizadas são casos particulares das equações gerais de movimento de um avião, conforme estabelecidas na seção 7.1. O diagrama de forças para o caso de subida estabilizada pode ser visualizado na Figura 7.4.

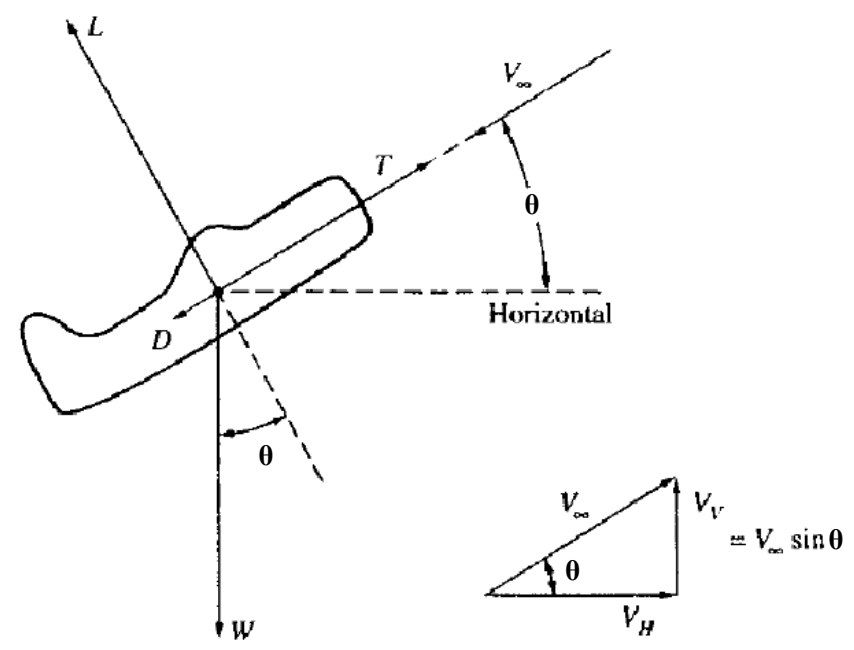

Figura 7.4: Diagrama de forças e velocidade para subida estabilizada (ANDERSON, 1999).

Como não há variações de velocidade e considerando os raios $r_{1} \mathrm{e} r_{2}$ infinitamente grandes para o voo em uma linha reta, colocam-se os termos $\frac{d V_{\infty}}{d t}, \frac{V_{\infty}{ }^{2}}{r_{1}}$ e $\frac{\left(V_{\infty} \cos \theta\right)^{2}}{r_{2}}$ iguais a zero nas equações (50), (51) e (52). Consideram-se também os ângulos $\varphi$ e $\varepsilon$ iguais a zero, visto que não há rolagem e a tração está alinhada com arrasto. Isto resulta no seguinte balanço de forças: 


$$
T-D-W \operatorname{sen}(\theta)=0
$$

$$
L-W \cos (\theta)=0
$$

A partir do diagrama de velocidades, pode-se obter a taxa de subida pela composição da velocidade de voo $V_{\infty}$ na direção vertical:

$$
\operatorname{Taxa}_{\text {Subida }}=V_{\infty} \operatorname{sen}(\theta)
$$

Multiplicando a equação (68) por $V_{\infty} / W$, tem-se:

$$
\operatorname{Taxa}_{\text {Subida }}=V_{\infty} \operatorname{sen}(\theta)=\frac{T V_{\infty}-D V_{\infty}}{W}
$$

Na qual $T V_{\infty}$ é a potência disponível e $D V_{\infty}$ é a potência de arrasto, sendo assim podese definir que:

$$
\begin{gathered}
\text { Excesso }_{\text {Potência }}=T V_{\infty}-D V_{\infty} \\
\text { Taxa }_{\text {Subida }}=\frac{\text { Excesso }_{\text {Potência }}}{W}
\end{gathered}
$$

Durante uma subida ou descida estabilizadas, há impacto no arrasto do avião devido ao impacto na força de sustentação (equação (69)) se comparado com o balanço de forças do voo nivelado e estabilizado. Este impacto é estabelecido pela polar de arrasto.

As equações e considerações para a descida estabilizada são similares, entretanto, o ângulo $\theta$ é negativo a força de tração deve ser menor em módulo que a força de arrasto, visto 
que uma parcela do peso compensa essa diferença para que a descida estabilizada seja possível. No caso da descida estabilizada não faz sentido o conceito de excesso de potência.

\subsection{Caracterização do avião}

A aeronave analisada neste trabalho é do tipo comercial de transporte de passageiros e de utilização regional, com objetivo de certificação conforme os requisitos dos principais órgãos homologadores: FAA (ESTADOS UNIDOS DA AMÉRICA, 2010), EASA (EUROPA, 2007) e ANAC (BRASIL, 2009). As principais características são:

- Alcance: 2200 km, com ocupação total e reserva de combustível igual a 10\% do combustível da missão;

- Carga paga: 52 passageiros

- Velocidade de cruzeiro: 0,78 Mach

- Altitude máxima operacional: $12500 \mathrm{~m}$;

- Distância de decolagem: 1500 m em nível do mar, em condições ambientes padrão (“International Organization for Standardization”, 1975) com máximo peso de decolagem;

- Distância de pouso: 1350 m em nível do mar, com máximo peso de pouso;

- Tripulação: dois pilotos e um atendente de bordo.

As três vistas e principais dimensões da aeronave podem ser visualizadas na Figura 7.5 . 

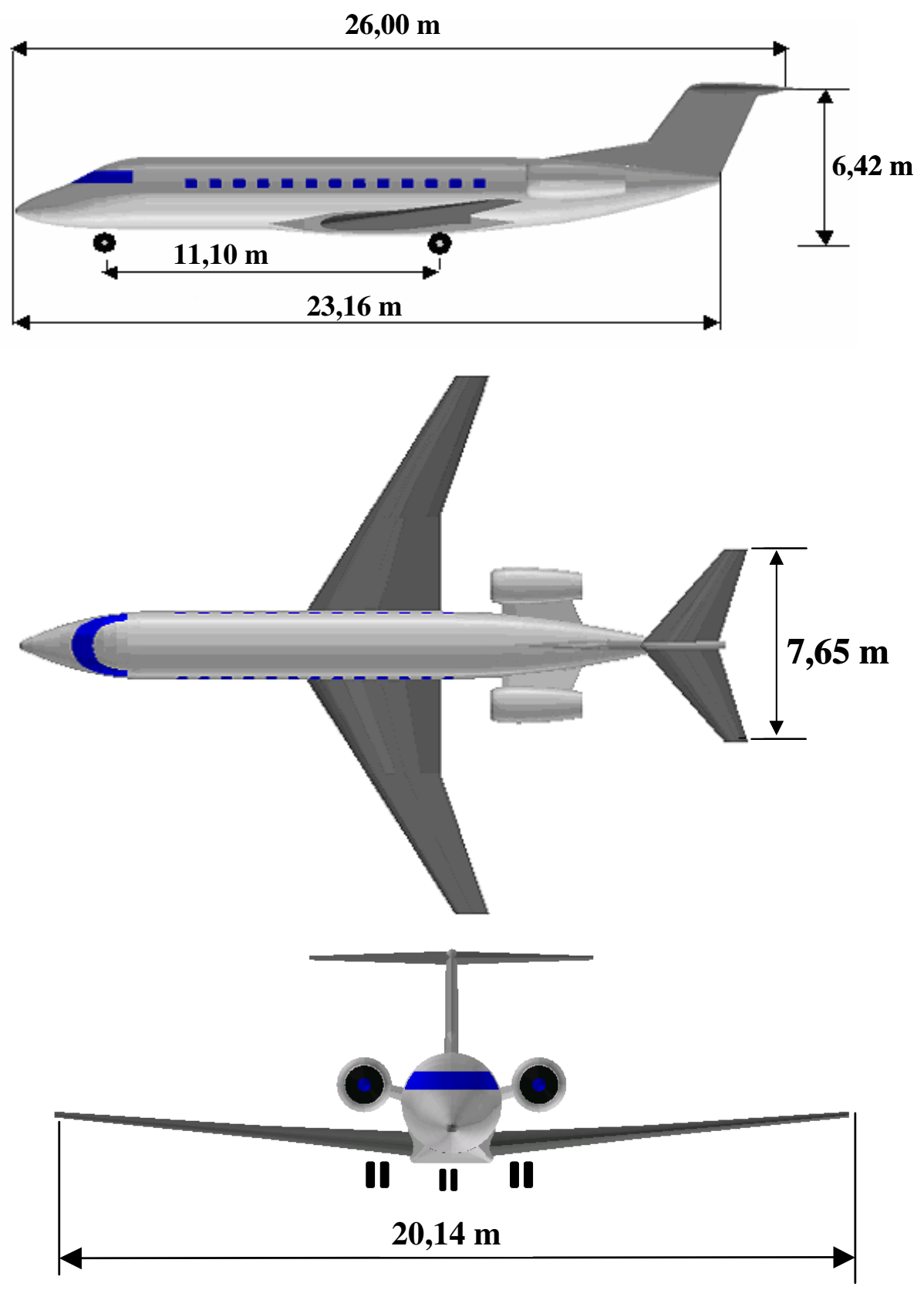

Figura 7.5: Três vistas e principais dimensões.

A missão típica considerada é caracterizada pelas Figura 7.6 e Figura 7.7. Esta missão foi considerada para ambas as versões da aeronave: com sistemas convencionais e com sistemas mais elétricos. 
Missão Típica - Altitude vs. Tempo

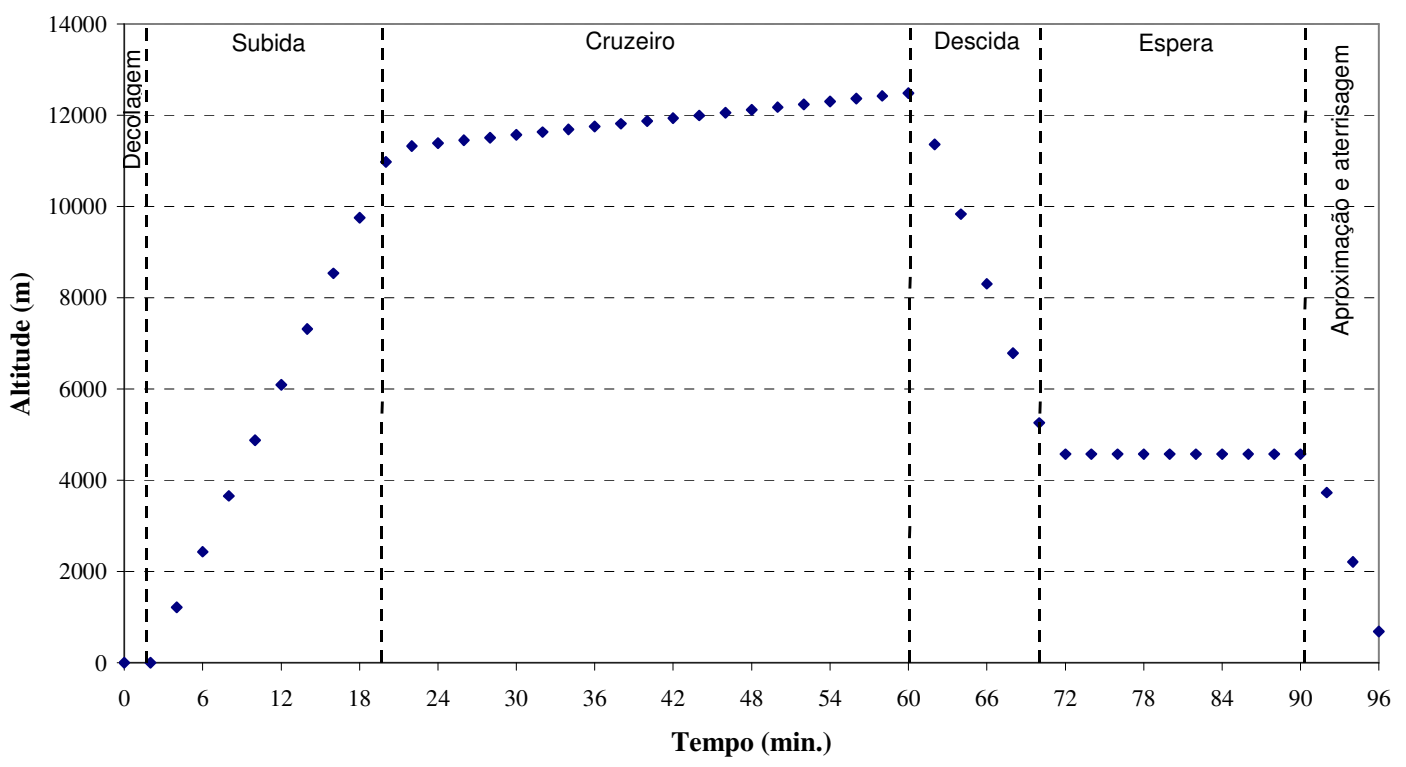

Figura 7.6: Missão típica - altitude vs. tempo.

Missão Típica - Velocidade vs. Tempo

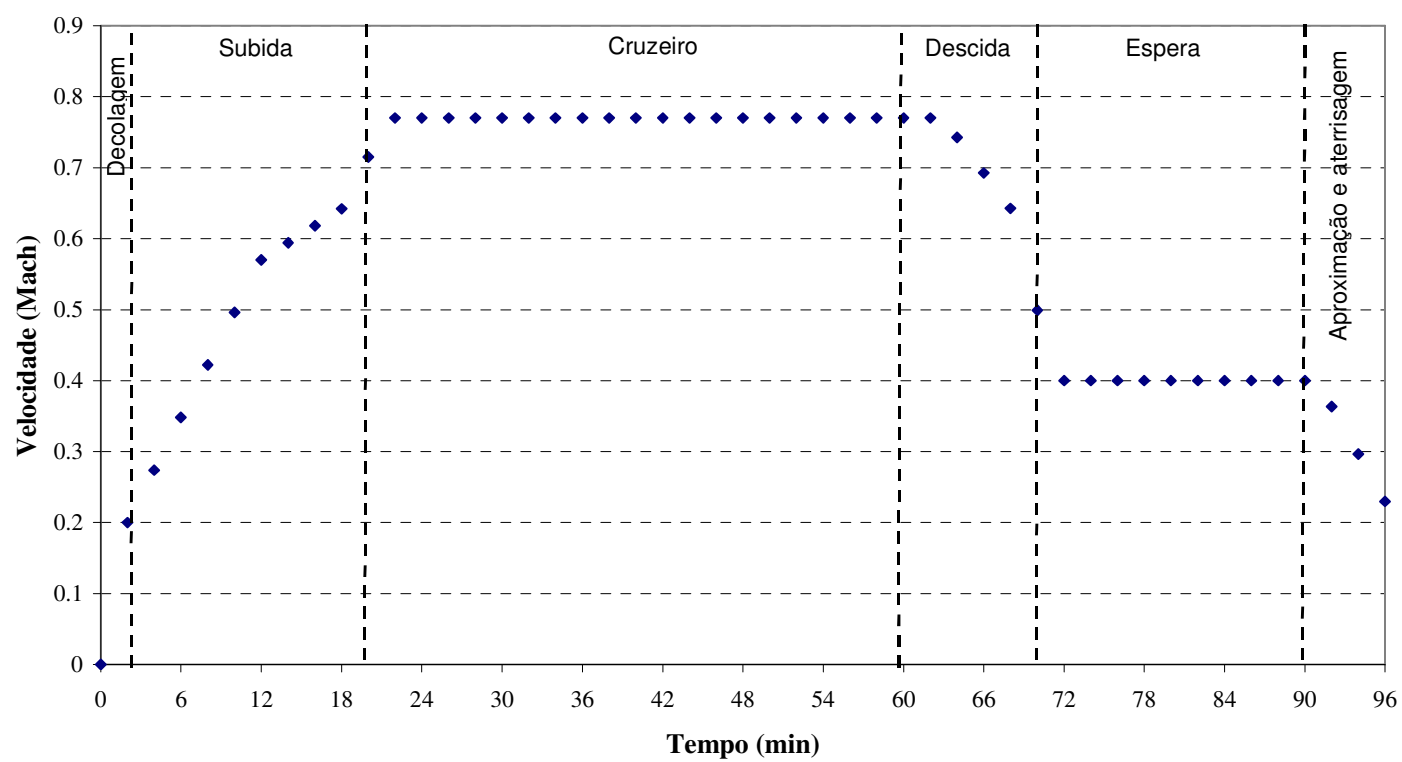

Figura 7.7: Missão típica - velocidade vs. tempo. 


\section{$8 \quad$ Modelagem de Sistemas Aeronáuticos}

Todo sistema aeronáutico deve ser dimensionado para condições extremas de operação a partir do envelope de operação da aeronave, garantindo assim sua operação em qualquer condição de voo prevista. Primeiramente, calculam-se o consumo de potência para dimensionamento dos sistemas nas condições críticas de operação e, em seguida, o consumo para cada fase do voo simulado e que não necessariamente é feito nas condições críticas.

Apresentam-se assim nessa seção as principais considerações e resultados no cálculo dos requisitos de dimensionamento dos sistemas de gerenciamento de ar (sistema de controle ambiental e proteção contra gelo) e as considerações de modelagem para os sistemas convencionais e para os sistemas mais elétricos para a simulação da missão típica ilustrada na seção 7.6.

8.1. Requisitos de dimensionamento dos sistemas de gerenciamento de ar

Os requisitos de dimensionamento dos sistemas de gerenciamento de ar devem ser calculados para garantir o adequado cumprimento da missão e segurança de voo. Tais requisitos são refletidos em requisitos de certificação de aeronaves de transporte de passageiros conforme publicações dos principais órgãos homologadores (ESTADOS UNIDOS DA AMÉRICA, 2010; EUROPA, 2007; BRASIL, 2009).

\subsubsection{Requisitos de ar para o sistema de controle ambiental}

Os requisitos de vazão de ar para o sistema de controle ambiental devem atender simultaneamente aos seguintes requisitos específicos: fornecimento de ar de renovação, o fornecimento de ar para aquecimento de resfriamento de cabine e fornecimento de ar para pressurização. Tais requisitos são resultados do cumprimento dos requisitos de certificação de ventilação de cabine, concentração de ozônio e pressurização de cabines (ESTADOS UNIDOS DA AMÉRICA, 2010; EUROPA, 2007; BRASIL, 2009).

Os requisitos gerais de ar para o sistema de controle ambiental da aeronave avaliada encontram-se na tabela Tabela 8.1. As próximas seções mostram o cálculo e resultados 
individuais de cada requisito específico (ar de renovação, aquecimento/resfriamento e pressurização).

Tabela 8.1: Requisitos de insuflamento de ar para o sistema de controle ambiental.

\begin{tabular}{ccc}
\hline Fase de Voo & Altitude (m) & $\begin{array}{c}\text { Vazão de ar total para sistema } \\
\text { de controle ambiental [kg/s] }\end{array}$ \\
\hline Taxi & 0 & 0,378 \\
Decolagem & 0 & 0,447 \\
Subida & 1250 & 0,404 \\
Subida & 2499 & 0,365 \\
Subida & 3749 & 0,344 \\
Subida & 4999 & 0,308 \\
Subida & 6248 & 0,275 \\
Subida & 7498 & 0,275 \\
Subida & 8748 & 0,304 \\
Subida & 9997 & 0,346 \\
Subida & 11247 & 0,380 \\
Cruzeiro & 12497 & 0,363 \\
Descida & 11247 & 0,375 \\
Descida & 9997 & 0,341 \\
Descida & 8748 & 0,304 \\
Descida & 7498 & 0,275 \\
Descida & 6248 & 0,275 \\
Descida & 4999 & 0,308 \\
Descida & 3749 & 0,344 \\
Descida & 2499 & 0,365 \\
Descida & 1250 & 0,404 \\
Aproximação e Pouso & 0 & 0,447 \\
Taxi & 0 & 0,378 \\
\hline & &
\end{tabular}

8.1.1.1. Fornecimento de ar de renovação

Para garantir o cumprimento de requisitos operacionais, os compartimentos ocupados devem ser ventilados sempre que o avião estiver em operação. Para satisfazer este requisito o sistema deve operar normalmente com a fonte de ar embarcada (motores ou unidade auxiliar de potência), podendo ser também operado em solo a partir de fontes externas. No caso de falha do sistema principal, a ventilação deve ser suprida por um sistema alternativo.

A qualidade do ar da cabine depende da quantidade de ar renovação fornecido e da taxa de geração de contaminantes no interior da cabine. A taxa de ar externo admitido deve ser suficiente para diluição dos contaminantes em níveis que não causem desconforto e prejuízos à saúde. Parte do ar externo pode ser substituída por ar recirculado, desde que este seja tratado para remoção de aerossóis e gases contaminantes. Os sistemas de ventilação da 
cabine dos aviões podem usar somente ar sangrado ou uma mistura de ar sangrado com ar recirculado. Um sistema de ar condicionado típico deve fornecer uma quantidade suficiente de ar para satisfazer os requisitos mínimos de ventilação $(0,0042 \mathrm{~kg} / \mathrm{s}$ por ocupante), diluição das concentrações de dióxido e monóxido de carbono e controle de odores. $\mathrm{O}$ ar recirculado passa por filtros de particulados, que devem ser do tipo HEPA ("High Efficiency Particulate Air"). Alguns aviões que operam em ambientes onde altos níveis de ozônio são esperados necessitam de conversores catalíticos, para transformar o ozônio em oxigênio.

O fornecimento mínimo de ar para o avião analisado para cumprir com os requisitos mínimos de ventilação é de $0,2287 \mathrm{~kg} / \mathrm{s}$, conforme número de ocupantes especificado na seção 7.6.

\subsubsection{Fornecimento de ar para resfriamento e aquecimento de cabine}

O objetivo desta seção é apresentar um método para determinar a quantidade de ar a ser insuflada na cabine para resfriamento e aquecimento das cargas térmicas envolvidas durante as duas principais operações da aeronave: voo e operação em solo. O cálculo da carga térmica de uma aeronave envolve diversas considerações sobre transferência de calor e modelagem da cabine: a parede da cabine é modelada por meio de camadas de materiais com diferentes propriedades térmicas, a transferência de calor por convecção é aproximada por um escoamento paralelo a uma placa plana, sendo desconsiderados efeitos de curvatura da fuselagem, o regime considerado na análise é permanente, ou seja, os fluxos de calor não variam com o tempo. A troca de calor é modelada pelos seguintes processos, conforme mostra a Figura 8.1:

- convecção entre camada limite e parede externa da fuselagem;

- radiação entre a parede externa da fuselagem e o ambiente externo à cabine;

- radiação solar diretamente no interior da cabine através das áreas transparentes, sobre pessoas, equipamentos, poltronas, etc;

- condução através da parede da fuselagem;

- convecção entre o ar da cabine e a superfície interna da cabine (acabamento interno);

- convecção entre o ar da cabine e pessoas;

- convecção e radiação de equipamentos elétricos. 


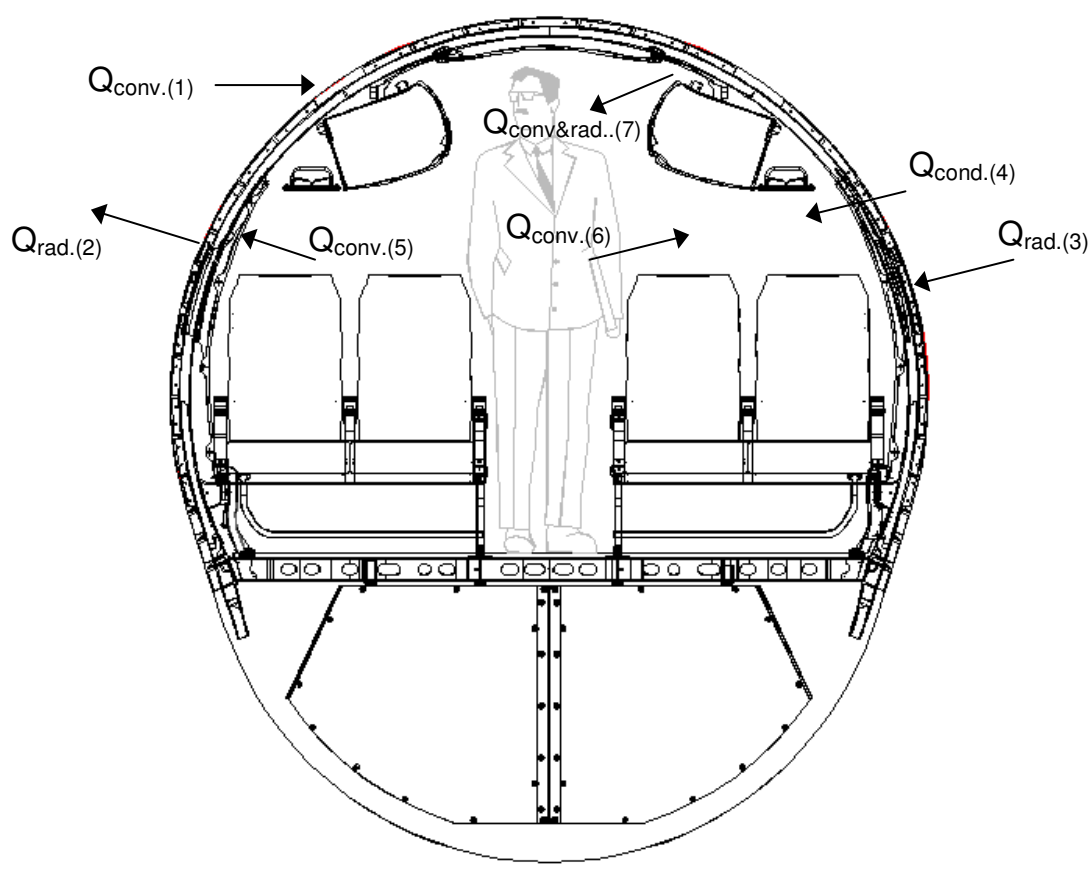

Figura 8.1: Efeitos considerados na troca de calor da cabine (GANDOLFI, 2004).

\subsection{Transferência de calor entre ar e fuselagem}

Existem duas situações que devem ser consideradas e são distintas: transferência de calor em voo e em solo.

A transferência de calor $\left(\dot{Q}_{\text {ext }}\right)$ entre ar e a fuselagem em voos abaixo de Mach igual a 2 é determinada pela equação (74).

$$
\dot{Q}_{e x t}=h_{e} A\left(T_{r}-T_{w}\right)
$$

Onde:

$A$ : área;

$h_{e}$ : coeficiente externo de transferência de calor;

$T_{w}$ : temperatura da superfície externa da fuselagem;

$T_{r}$ : temperatura de recuperação; 


$$
T_{r}=T_{s}\left(1+R \frac{\gamma-1}{2} M^{2}{ }^{2}\right)
$$

Onde fator de recuperação R é definido:

- para escoamento laminar:

$$
R=\sqrt{N_{\operatorname{Pr}}}
$$

- para escoamento turbulento:

$$
R=\sqrt[3]{N_{\operatorname{Pr}}}
$$

Sendo:

$\mathrm{N}_{\mathrm{Pr}}=0,71$ (número de Prandtl);

$\gamma$ : razão de calores específicos para o ar $(1,4)$;

Mach: número de Mach (razão entre velocidades do avião e do som no ar).

Em voos subsônicos e supersônicos a velocidades com números de Mach baixos, o coeficiente de transferência de calor $h_{e}$ é grande em comparação com os demais coeficientes da parede da fuselagem e, além disso, os efeitos de radiação da fuselagem para o meio e do meio para a fuselagem podem ser desprezados. Sendo assim, a temperatura da parede externa da fuselagem pode ser considerada igual à temperatura de recuperação $\left(T_{r}\right)$.

\subsection{Condução pela parede da fuselagem}

A transferência de calor entre a parede externa da fuselagem e as áreas ocupadas ocorre principalmente por condução. Entretanto, existem alguns fatores que devem ser levados em conta no cálculo da transferência de calor:

- a parede da cabine é composta por várias camadas de diferentes materiais; 
- a construção não é homogênea, isso acaba criando fluxos de calor paralelos;

- há espaços vazios preenchidos por ar nos quais há uma combinação de condução, convecção natural e radiação;

- os componentes estruturais como cavernas, cavernas de pressão e piso geralmente agem como aletas, o que torna o isolamento mais crítico;

- a transferência de calor na parede interna da fuselagem (acabamento interno) é por convecção;

- a transferência de calor pode ocorrer para ou de compartimentos adjacentes não condicionados nos quais a temperatura é desconhecida e difícil de se determinar.

Para simplificar os cálculos, foi considerado que o fluxo de calor é unidimensional e flui por linhas radiais sem fluxo de calor circunferencial ou longitudinal. Uma parede composta de diversas camadas pode ser visualizada na Figura 8.2.

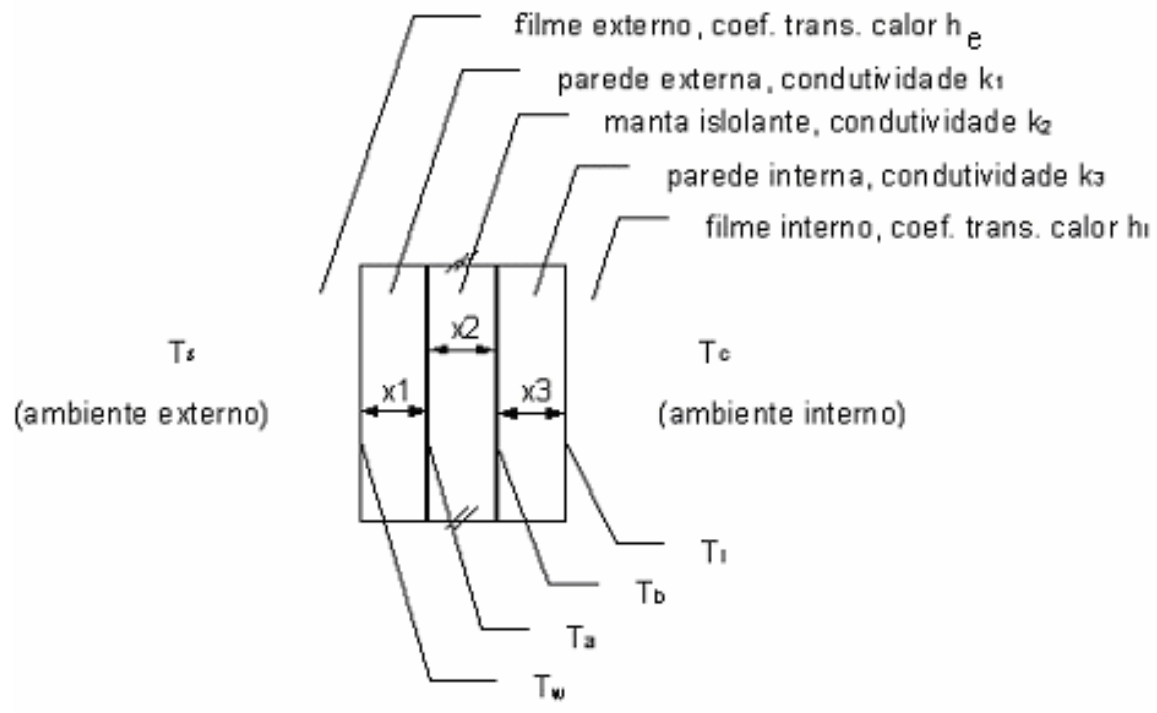

Figura 8.2: Parede composta da fuselagem (GANDOLFI, 2004).

Num processo em regime permanente, a transferência de calor é igual em todas as camadas. $\mathrm{O}$ equacionamento da transferência de calor através da parede composta mostrada na Figura 8.2 em regime permanente é dado como se segue:

$$
\dot{Q}=h_{e} A\left(T_{s}-T_{w}\right)
$$




$$
\begin{gathered}
\dot{Q}=\frac{k_{1}}{x_{1}} A\left(T_{w}-T_{a}\right) \\
\dot{Q}=\frac{k_{2}}{x_{2}} A\left(T_{a}-T_{b}\right) \\
\dot{Q}=\frac{k_{3}}{x_{3}} A\left(T_{b}-T_{i}\right) \\
\dot{Q}=h_{i} A\left(T_{i}-T_{c}\right)
\end{gathered}
$$

Onde:

$k_{i}$ : condutividade;

$x_{i}$ : espessura de parede;

$T_{a}, T_{b}$ : temperaturas superficiais das camadas a e b da fuselagem;

$T_{i}$ : temperatura da superfície interna da cabine;

$h_{i}$ : coeficiente interno de transferência de calor por convecção.

Ainda para regime permanente, a transferência de calor por condução é igual em cada seção da parede. Somando as equações (78) a (82) e isolando Q vem:

$$
\dot{Q}_{\text {cond }}=U A\left(T_{s}-T_{c}\right)
$$

Onde U é o coeficiente global de transferência de calor na parede dado por:

$$
U=\frac{1}{\frac{1}{h_{e}}+\sum_{i=1}^{3} \frac{x_{i}}{k_{i}}+\frac{1}{h_{i}}}
$$


para a parede da Figura 8.2.

Quando se considera um circuito térmico reduzido, desde a temperatura da cabine até a temperatura da superfície externa da fuselagem, esta considerada igual à temperatura de recuperação como hipótese simplificadora, o coeficiente de transferência de calor externo por convecção entre ar e fuselagem $h_{e}$ não deve ser incluído no cálculo do coeficiente global de transferência de calor da parede da fuselagem $(U)$. Nesse caso a equação (83) fica:

$$
\dot{Q}_{\text {cond }}=U A\left(T_{r}-T_{c}\right)
$$

\subsection{Coeficiente interno de transferência de calor por convecção}

A transferência de calor entre as paredes internas da fuselagem e o ar dos compartimentos pode ocorrer por convecção forçada, devido à ventilação da cabine, ou por convecção livre, em compartimentos não ventilados. Experimentos conduzidos para aplicações em aeronaves comerciais indicam valores esperados para o coeficiente de convecção. A equação que se ajusta a esses dados experimentais para este coeficiente é, em unidades inglesas (SAE, 1990a):

$$
h_{i}=5,6779\left(2+1,03 V_{a r}\right)
$$

Onde,

$V_{a r}$ : velocidade do fluxo de ar sobre a superfície interna da fuselagem.

Geralmente as velocidades do ar nos compartimentos ocupados variam de 0 a $1 \mathrm{~m} / \mathrm{s}$. A equação anterior também pode ser usada para estimar coeficientes de transferência de calor externo para operações estáticas em solo. Neste caso, podem-se usar velocidades em torno de $7 \mathrm{~m} / \mathrm{s}$

\subsection{Radiação solar através das janelas}


A radiação solar, que possui baixo comprimento de onda, é transmitida diretamente através das áreas transparentes para o interior da cabine incidindo sobre pessoas, poltronas, equipamentos, etc. Entretanto, a energia irradiada pelo interior da cabine não passa pelas áreas transparentes porque essas áreas são opacas às ondas de grande comprimento, emitidas por superfícies a temperaturas relativamente baixas no interior da cabine. Portanto, a energia irradiada pelo Sol que passa através das áreas transparentes deve ser incluída no cálculo da carga térmica em sua totalidade. Pára-brisas, janelas laterais da cabine de comando e janelas de passageiros possuem várias camadas compostas por materiais diferentes, com transmissividades diferentes $(\tau)$. A carga térmica proveniente da radiação solar que atinge o interior do avião através de uma área transparente é dada a seguir:

$$
\dot{Q}_{\text {rad }}=G_{s} \frac{A_{p}}{2} \prod_{i=1}^{n} \tau_{i}
$$

\subsection{Fluxo de calor transferido por ocupantes}

Em áreas com grande densidade de pessoas, o fluxo de calor transferido pelos ocupantes pode ser um fator importante no cálculo da carga térmica total. A Figura 8.3 mostra o fluxo de calor transferido da radiação e convecção de seres humanos em diversas atividades versus a temperatura de bulbo seco. A Figura 8.4 mostra o fluxo de entalpia relacionado à perda de água por seres humanos nas mesmas situações:

- Curva A, pessoas trabalhando, taxa metabólica de $384 \mathrm{~W}$;

- Curva B, pessoas trabalhando, taxa metabólica de 249 W;

- Curva C, pessoas trabalhando, taxa metabólica de 193 W;

- Curva D, pessoas sentadas e descansando, taxa metabólica de $117 \mathrm{~W}$. 

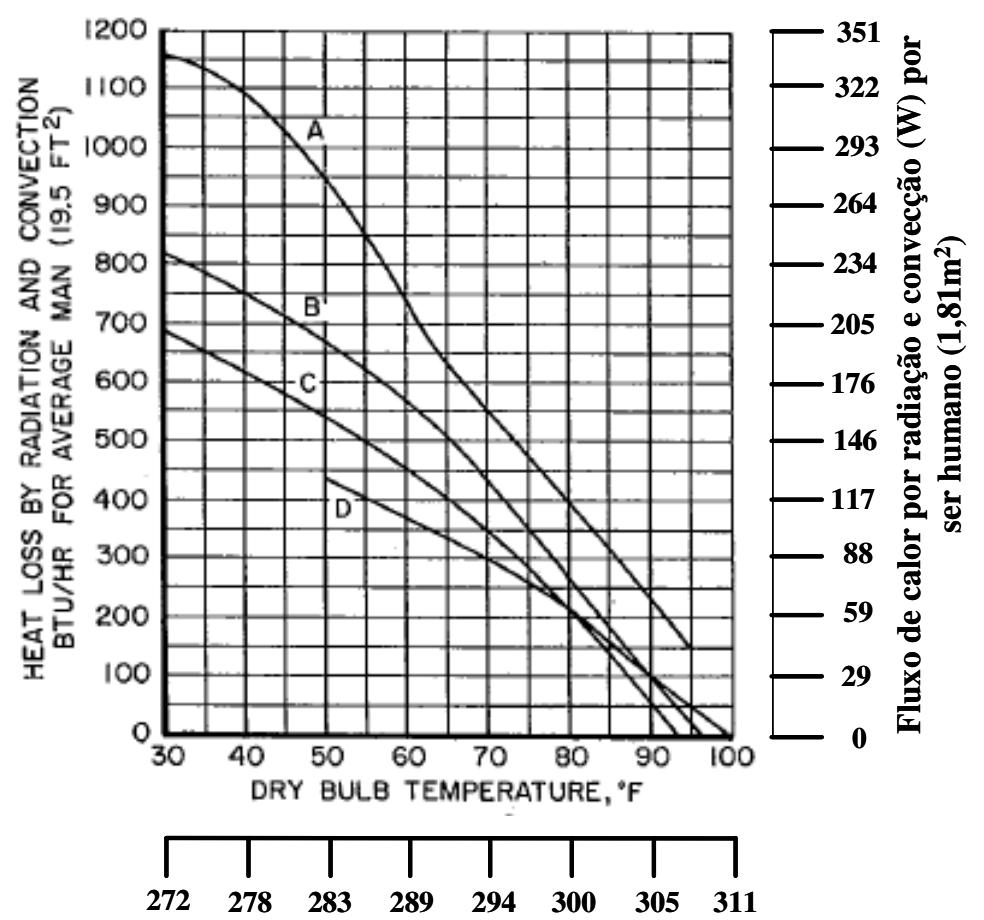

Temperatura de bulbo seco (K)

Figura 8.3: Relação entre fluxo de calor por radiação e convecção do corpo humano versus temperatura de bulbo seco para ar estagnado. (SAE, 1990a)
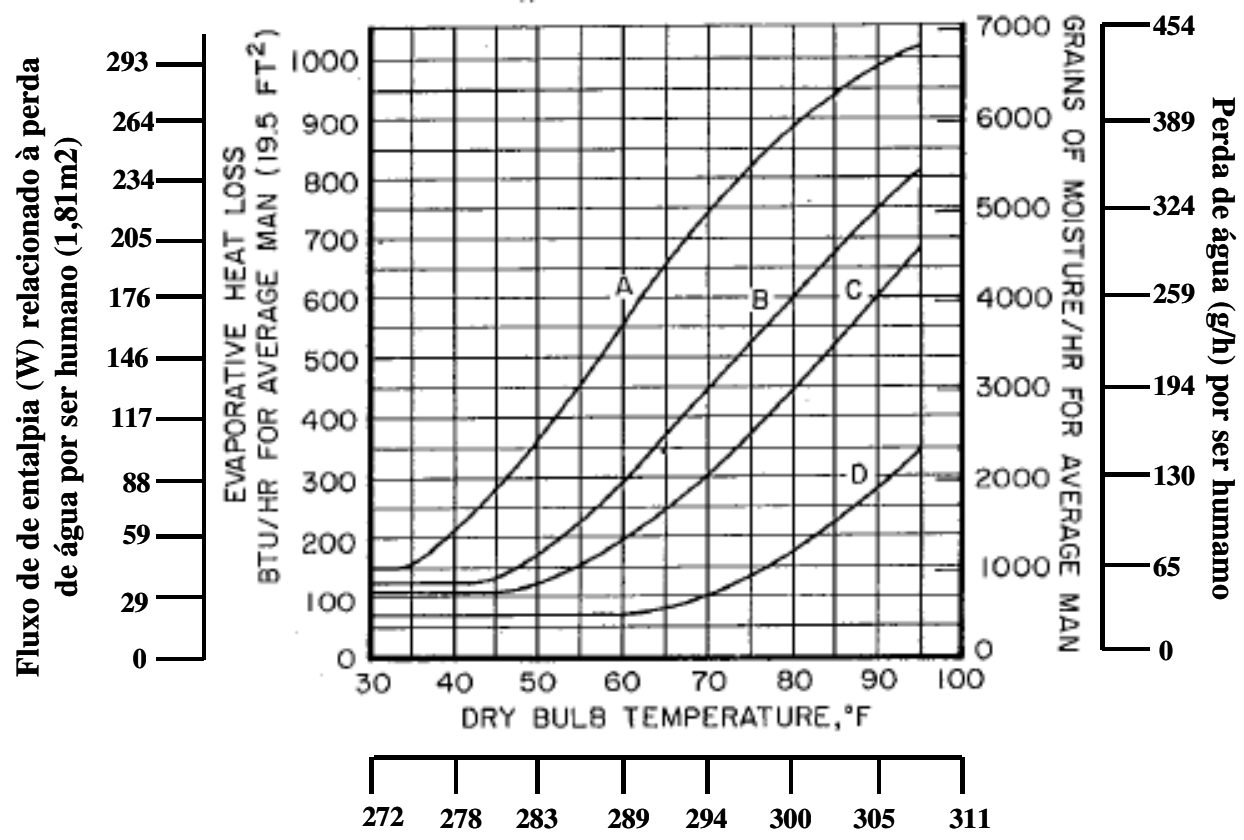

Temperatura de bulbo seco (K)

Figura 8.4: Relação entre fluxo de entalpia relacionado à perda de água do corpo humano versus temperatura de bulbo seco para ar estagnado. (SAE, 1990a) 
O fluxo de calor evaporativo é na forma de transpiração, ou seja, mistura evaporativa, e não tem efeito na temperatura de bulbo seco do ambiente. Para um sistema que usa $100 \%$ de ar de renovação (sem recirculação), o fluxo de calor evaporativo dos ocupantes não entra no cálculo da carga térmica de resfriamento, mas entra no cálculo da umidade relativa do ar da cabine (SAE, 1990a). Se uma parte do ar for circulada, então o fluxo de calor evaporativo também deve ser incluído no cálculo da carga térmica total de cabine.

\subsection{Carga elétrica}

A quantidade de equipamentos elétrico/eletrônicos nos aviões hoje em dia é alta. Um cálculo conservativo estima que a carga térmica produzida por esses equipamentos pode ser obtida assumindo que todo equipamento elétrico converte toda sua potência elétrica em fluxo de calor, o qual é lançado na cabine.

Geralmente os equipamentos elétricos podem operar em ambientes com temperaturas maiores que a temperatura da cabine. Se for possível enclausurar esses equipamentos em compartimentos isolados da cabine e passar uma parte do ar da cabine através desse compartimento, antes de exauri-lo, a carga térmica de resfriamento da cabine pode ser reduzida.

Devido à fase preliminar de concepção que se encontra o avião analisado neste trabalho, considerou-se $100 \%$ da potência elétrica dos equipamentos elétrico/eletrônicos em fluxo de calor no cálculo dos requisitos de ar para resfriamento e aquecimento de cabine.

\subsection{Insuflamento de ar para aquecimento e resfriamento de cabine}

A quantidade de ar mínima insuflada na cabine para resfriamento ou aquecimento em regime permanente, de acordo com a carga térmica, depende da temperatura de entrada desse ar na cabine, como segue: 


$$
\dot{m}_{a r}=\frac{\dot{Q}_{\text {total }}}{C_{p}\left(T_{c}-T_{a r}\right)}
$$

Onde,

$\dot{m}_{a r}$ : massa de ar insuflada na cabine;

$C_{p}:$ calor específico do ar;

$T_{a r}$ : temperatura do ar insuflado na cabine;

$Q_{\text {total }}$ : resultante de transferência de calor.

Sendo assim, no cálculo da massa de ar mínima insuflada, a temperatura de entrada desse ar deve ser fornecida de acordo com o funcionamento das máquinas de ar condicionado. A vazão de ar é calculada para manter a cabine em determinada condição de temperatura (22 $\left.{ }^{\circ} \mathrm{C}\right)$. A Tabela 8.2 mostra os principais resultados referentes à análise de carga térmica e requisitos de ar do sistema de controle ambiental para dimensionamento em condições extremas de aquecimento de cabine do avião analisado. A Tabela 8.3 mostra os principais resultados referentes à análise de carga térmica e requisitos de ar do sistema de controle ambiental para dimensionamento em condições extremas de resfriamento de cabine do avião analisado. 
Tabela 8.2: Cargas térmicas e requisitos de insuflamento de ar para dimensionamento em condições extremas de aquecimento de cabine.

\begin{tabular}{|c|c|c|c|c|c|c|c|c|c|c|c|}
\hline Fase de Voo & $\begin{array}{l}\text { Altitude } \\
\quad(\mathbf{m})\end{array}$ & $\begin{array}{c}\text { Temperatura do ar } \\
\text { de } \\
\text { insuflamento de } \\
\text { cabine - } \mathbf{T}_{\text {ar }}[\mathrm{K}] \\
\end{array}$ & Mach & $\begin{array}{c}\text { Temperatura } \\
\text { da } \\
\text { fuselagem }-\mathbf{T}_{\mathbf{r}} \\
{[\mathrm{K}]} \\
\end{array}$ & $\begin{array}{c}\text { Temperatura } \\
\text { do } \\
\text { ambiente externo - } \\
\mathbf{T}_{\mathrm{s}}[\mathrm{K}] \\
\end{array}$ & $\begin{array}{l}\mathbf{Q}_{\text {hum }} \\
{[\mathbf{k W}]}\end{array}$ & $\begin{array}{c}\mathbf{Q}_{\text {ele }} \\
{[\mathbf{k W}]}\end{array}$ & $\begin{array}{l}\mathbf{Q}_{\text {cond }} \\
{[\mathbf{k W}]}\end{array}$ & $\begin{array}{c}\mathbf{Q}_{\mathrm{rad}} \\
{[\mathbf{k W}]}\end{array}$ & $\begin{array}{l}Q_{\text {total }} \\
{[\mathbf{k W}]}\end{array}$ & $\begin{array}{c}\text { Vazão para aquecimento } \\
-\mathrm{m}_{\mathrm{ar}}[\mathrm{kg} / \mathrm{s}]\end{array}$ \\
\hline Taxi & 0 & 343 & 0,00 & 253 & 253 & 1,19 & 3,00 & $-10,44$ & 0,00 & $-6,25$ & 0,125 \\
\hline Decolagem & 0 & 343 & 0,38 & 260 & 253 & 1,19 & 3,00 & $-8,91$ & 0,00 & $-4,71$ & 0,095 \\
\hline Subida & 1250 & 343 & 0,41 & 252 & 245 & 1,19 & 3,00 & $-10,66$ & 0,00 & $-6,47$ & 0,130 \\
\hline Subida & 2499 & 343 & 0,44 & 245 & 237 & 1,19 & 3,00 & $-12,39$ & 0,00 & $-8,19$ & 0,164 \\
\hline Subida & 3749 & 343 & 0,55 & 241 & 229 & 1,19 & 3,00 & $-13,35$ & 0,00 & $-9,16$ & 0,184 \\
\hline Subida & 4999 & 343 & 0,59 & 234 & 221 & 1,19 & 3,00 & $-14,93$ & 0,00 & $-10,74$ & 0,215 \\
\hline Subida & 6248 & 343 & 0,64 & 228 & 213 & 1,19 & 3,00 & $-16,46$ & 0,00 & $-12,26$ & 0,246 \\
\hline Subida & 7498 & 343 & 0,69 & 222 & 204 & 1,19 & 3,00 & $-17,93$ & 0,00 & $-13,73$ & 0,275 \\
\hline Subida & 8748 & 343 & 0,75 & 216 & 196 & 1,19 & 3,00 & $-19,33$ & 0,00 & $-15,14$ & 0,304 \\
\hline Subida & 9997 & 343 & 0,75 & 207 & 188 & 1,19 & 3,00 & $-21,42$ & 0,00 & $-17,23$ & 0,346 \\
\hline Subida & 11247 & 343 & 0,75 & 200 & 182 & 1,19 & 3,00 & $-23,13$ & 0,00 & $-18,94$ & 0,380 \\
\hline Cruzeiro & 12497 & 343 & 0,82 & 203 & 182 & 1,19 & 3,00 & $-22,28$ & 0,00 & $-18,09$ & 0,363 \\
\hline Descida & 11247 & 343 & 0,77 & 201 & 182 & 1,19 & 3,00 & $-22,90$ & 0,00 & $-18,70$ & 0,375 \\
\hline Descida & 9997 & 343 & 0,77 & 208 & 188 & 1,19 & 3,00 & $-21,18$ & 0,00 & $-16,99$ & 0,341 \\
\hline Descida & 8748 & 343 & 0,75 & 216 & 196 & 1,19 & 3,00 & $-19,33$ & 0,00 & $-15,14$ & 0,304 \\
\hline Descida & 7498 & 343 & 0,69 & 222 & 204 & 1,19 & 3,00 & $-17,93$ & 0,00 & $-13,73$ & 0,275 \\
\hline Descida & 6248 & 343 & 0,64 & 228 & 213 & 1,19 & 3,00 & $-16,46$ & 0,00 & $-12,26$ & 0,246 \\
\hline Descida & 4999 & 343 & 0,59 & 234 & 221 & 1,19 & 3,00 & $-14,93$ & 0,00 & $-10,74$ & 0,215 \\
\hline Descida & 3749 & 343 & 0,55 & 241 & 229 & 1,19 & 3,00 & $-13,35$ & 0,00 & $-9,16$ & 0,184 \\
\hline Descida & 2499 & 343 & 0,44 & 245 & 237 & 1,19 & 3,00 & $-12,39$ & 0,00 & $-8,19$ & 0,164 \\
\hline Descida & 1250 & 343 & 0,41 & 252 & 245 & 1,19 & 3,00 & $-10,66$ & 0,00 & $-6,47$ & 0,130 \\
\hline $\begin{array}{l}\text { Aproximação e } \\
\text { Pouso }\end{array}$ & 0 & 343 & 0,38 & 260 & 253 & 1,19 & 3,00 & $-8,91$ & 0,00 & $-4,71$ & 0,095 \\
\hline Taxi & 0 & 343 & 0,00 & 253 & 253 & 1,19 & 3,00 & $-10,44$ & 0,00 & $-6,25$ & 0,125 \\
\hline
\end{tabular}


Tabela 8.3: Cargas térmicas e requisitos de insuflamento de ar para dimensionamento em condições extremas de resfriamento de cabine.

\begin{tabular}{|c|c|c|c|c|c|c|c|c|c|c|c|}
\hline Fase de Voo & $\begin{array}{l}\text { Altitude } \\
\text { (m) }\end{array}$ & $\begin{array}{c}\text { Temperatura do ar } \\
\text { de } \\
\text { insuflamento de } \\
\text { cabine }-\mathrm{T}_{\text {ar }}[\mathrm{K}] \\
\end{array}$ & Mach & $\begin{array}{c}\text { Temperatura } \\
\text { da } \\
\text { fuselagem }-T_{\mathbf{r}} \\
{[\mathrm{K}]} \\
\end{array}$ & $\begin{array}{c}\text { Temperatura } \\
\text { do } \\
\text { ambiente externo - } \\
\mathrm{T}_{\mathrm{s}}[\mathrm{K}] \\
\end{array}$ & $\begin{array}{c}\mathbf{Q}_{\text {hum }} \\
{[\mathbf{k W}]}\end{array}$ & $\begin{array}{c}\mathbf{Q}_{\text {ele }} \\
{[\mathbf{k W}]}\end{array}$ & $\begin{array}{l}Q_{\text {cond }} \\
{[k W]}\end{array}$ & $\begin{array}{c}\mathbf{Q}_{\mathrm{rad}} \\
{[\mathbf{k W}]}\end{array}$ & $\begin{array}{l}\mathbf{Q}_{\text {total }} \\
{[\mathbf{k W}]}\end{array}$ & $\begin{array}{l}\text { Vazão para } \\
\text { resfriamento - } \\
\text { mar }_{\text {arg }}[\mathrm{kg}]\end{array}$ \\
\hline Taxi & 0 & 263 & 0,00 & 313 & 313 & 4,08 & 3,00 & 3,85 & 3,08 & 14,00 & 0,38 \\
\hline Decolagem & 0 & 263 & 0,44 & 324 & 313 & 4,08 & 3,00 & 6,40 & 3,08 & 16,56 & 0,45 \\
\hline Subida & 1250 & 263 & 0,47 & 317 & 305 & 4,08 & 3,00 & 4,79 & 3,12 & 14,98 & 0,40 \\
\hline Subida & 2499 & 263 & 0,51 & 311 & 297 & 4,08 & 3,00 & 3,28 & 3,16 & 13,52 & 0,36 \\
\hline Subida & 3749 & 263 & 0,60 & 307 & 289 & 4,08 & 3,00 & 2,47 & 3,20 & 12,75 & 0,34 \\
\hline Subida & 4999 & 263 & 0,65 & 302 & 281 & 4,08 & 3,00 & 1,11 & 3,24 & 11,43 & 0,31 \\
\hline Subida & 6248 & 263 & 0,70 & 296 & 273 & 4,08 & 3,00 & $-0,17$ & 3,29 & 10,19 & 0,27 \\
\hline Subida & 7498 & 263 & 0,76 & 291 & 264 & 4,08 & 3,00 & $-1,35$ & 3,33 & 9,05 & 0,24 \\
\hline Subida & 8748 & 263 & 0,82 & 287 & 256 & 4,08 & 3,00 & $-2,42$ & 3,37 & 8,03 & 0,22 \\
\hline Subida & 9997 & 263 & 0,82 & 278 & 248 & 4,08 & 3,00 & $-4,54$ & 3,41 & 5,95 & 0,16 \\
\hline Subida & 11247 & 263 & 0,82 & 271 & 242 & 4,08 & 3,00 & $-6,28$ & 3,45 & 4,25 & 0,11 \\
\hline Cruzeiro & 12497 & 263 & 0,82 & 271 & 242 & 4,08 & 3,00 & $-6,28$ & 3,49 & 4,29 & 0,12 \\
\hline Descida & 11247 & 263 & 0,82 & 271 & 242 & 4,08 & 3,00 & $-6,28$ & 3,45 & 4,25 & 0,11 \\
\hline Descida & 9997 & 263 & 0,82 & 278 & 248 & 4,08 & 3,00 & $-4,54$ & 3,41 & 5,95 & 0,16 \\
\hline Descida & 8748 & 263 & 0,82 & 287 & 256 & 4,08 & 3,00 & $-2,42$ & 3,37 & 8,03 & 0,22 \\
\hline Descida & 7498 & 263 & 0,76 & 291 & 264 & 4,08 & 3,00 & $-1,35$ & 3,33 & 9,05 & 0,24 \\
\hline Descida & 6248 & 263 & 0,70 & 296 & 273 & 4,08 & 3,00 & $-0,17$ & 3,29 & 10,19 & 0,27 \\
\hline Descida & 4999 & 263 & 0,65 & 302 & 281 & 4,08 & 3,00 & 1,11 & 3,24 & 11,43 & 0,31 \\
\hline Descida & 3749 & 263 & 0,60 & 307 & 289 & 4,08 & 3,00 & 2,47 & 3,20 & 12,75 & 0,34 \\
\hline Descida & 2499 & 263 & 0,51 & 311 & 297 & 4,08 & 3,00 & 3,28 & 3,16 & 13,52 & 0,36 \\
\hline Descida & 1250 & 263 & 0,47 & 317 & 305 & 4,08 & 3,00 & 4,79 & 3,12 & 14,98 & 0,40 \\
\hline $\begin{array}{c}\text { Aproximação e } \\
\text { Pouso }\end{array}$ & 0 & 263 & 0,44 & 324 & 313 & 4,08 & 3,00 & 6,40 & 3,08 & 16,56 & 0,45 \\
\hline Taxi & 0 & 263 & 0,00 & 313 & 313 & 4,08 & 3,00 & 3,85 & 3,08 & 14,00 & 0,38 \\
\hline
\end{tabular}




\subsubsection{Sistema de pressurização}

Deve-se garantir a quantidade de ar mínima a ser insuflada na cabine para manter a pressurização em níveis adequados para a saúde humana. Para tanto, apresenta-se aqui um método comumente utilizado na indústria aeronáutica para cálculo desses requisitos de insuflamento de ar.

A arquitetura do sistema de pressurização de uma aeronave deve estar de acordo com requisitos de certificação (ESTADOS UNIDOS DA AMÉRICA, 2010; EUROPA, 2007; BRASIL, 2009). Os requisitos limitam a pressão de cabine até a uma pressão referente a 2439 metros de altitude nas categorias de transporte civil. A principal função do sistema de pressurização é manter níveis de pressão na cabine favorável às necessidades fisiológicas de passageiros e tripulação. Além disso, o sistema controla as taxas de mudança de pressão na cabine de acordo com a altitude do avião de modo a minimizar o desconforto dos passageiros e garantir a integridade estrutural da aeronave.

O controle de pressão da cabine é realizado por meio das válvulas de exaustão. Este controle pode ser feito pneumaticamente e/ou eletricamente das seguintes maneiras:

- Controle isobárico: o sistema mantém constante a pressão de cabine;

- Controle diferencial: o sistema mantém uma diferença constante entre a pressão na cabine e a pressão ambiente;

- Controle por taxa: são especificadas para o sistema taxas de subida e descida geralmente entre 90 e 150 metros por minuto;

- Controle híbrido: nesse caso o controlador especifica taxas de mudança de pressão que maximizem o conforto dos passageiros, de acordo com a fase do voo, respeitando o limite estrutural da aeronave e máxima altitude de cabine.

As válvulas de exaustão podem ser controladas pneumaticamente ou eletricamente, ou seja, no primeiro caso um mecanismo pneumático é responsável pela abertura e fechamento das válvulas, e, no segundo caso, o acionamento ocorre por meio de um motor elétrico. Válvulas de segurança também são instaladas e são independentes das válvulas de exaustão. Nesse caso, as válvulas de alívio de pressão positiva têm função de limitar a diferença entre a 
pressão na cabine e a pressão externa, de modo a garantir a integridade estrutural da aeronave em caso de uma pane no sistema de pressurização. As válvulas de alívio de pressão negativa impossibilitam que a pressão interna da cabine se torne menor que a pressão externa.

\subsection{Vazamentos de cabine}

Os requisitos de insuflamento de ar para manter a pressurização adequada são obtidos por estimativas dos vazamentos de ar que ocorrem durante o voo. Os vazamentos de ar da cabine devem ser mantidos em níveis baixos de modo que essa vazão possa ser usada para resfriamento de equipamentos, por meio de drenos localizados nas baias de equipamentos eletrônicos, e remoção de odores, por meio de drenos localizados nos lavatórios ou toaletes. Desse modo, se houver perda da fonte de vazão de ar para pressurização da cabine haverá mais tempo para a aeronave descer e atingir uma altitude segura. Os vazamentos de cabine são causados por:

- exaustão de ar em toalete;

- drenos de água;

- aberturas diversas: drenos para remoção de ar da baia de equipamentos eletrônicos, drenos em regiões de instalação de cilindros de oxigênio;

- aberturas causadas problemas no projeto estrutural e problemas de controle de qualidade na fabricação (aberturas não intencionais);

A vazão máxima que pode ser tolerada é aquela que, somada com a vazão essencial de exaustão, totaliza um fluxo menor que o fluxo resultado da perda inadvertida de uma porção razoável da fonte de pressurização da cabine, no máximo diferencial de pressão permitido. A modelagem do vazamento de cabine é feita com o cálculo do fluxo de ar através de um orifício equivalente à soma da área de todos os orifícios (aberturas intencionais e não intencionais) e, de acordo com uma pressão de cabine especificada, temperatura do ar na cabine e altitude de voo. A área do orifício equivalente (SAE, 1991) pode ser calculada pela seguinte equação de escoamento compressível:

$$
C A=(6,4194 E-5) \frac{D \sqrt{T_{c_{-} \max H}}}{P_{c_{-} \max H} Z}
$$


Onde $\mathrm{Z}$ é o fator de razão de pressão, para razões entre 1 e 0,53 .

$$
Z=\sqrt{\left[\frac{P_{a}}{P_{c}}\right]^{2 / \gamma}-\left[\frac{P_{a}}{P_{c}}\right]^{(\gamma+1) / \gamma}}
$$

$P_{a}$ : pressão ambiente

$P_{c}$ : pressão na cabine

$P_{c_{-} \max H}:$ pressão da cabine em máxima altitude de cabine

$T_{c_{-} \max H}$ : temperatura do ar na cabine em máxima altitude de cabine

$D$ : vazamento de ar não controlado

Para razões iguais ou menores que 0,53 há o surgimento de escoamento com velocidade sônica no orifício, sendo assim, nessas condições $Z=0,256$ e a equação (90) não é mais usada. Forças aerodinâmicas e vibrações podem ter um pequeno efeito sobre a área de vazamento, mas assume-se que este efeito seja irrisório. A área de vazamento considerada é 9,518E-4 $\mathrm{m}^{2}$. A Tabela 8.4 mostra os requisitos de ar para pressurização conforme perfil de pressurização do avião analisado.

Tabela 8.4: Requisitos de insuflamento de ar para pressurização.

\begin{tabular}{ccccc}
\hline Fase de Voo & $\begin{array}{c}\text { Altitude } \\
{[\mathbf{m}]}\end{array}$ & $\begin{array}{c}\text { Pressão ambiente } \mathbf{P}_{\mathbf{a}} \\
\text { [bar] }\end{array}$ & $\begin{array}{c}\text { Pressão de cabine }-\mathbf{P}_{\mathbf{c}} \text { Vazão para pressurização - D } \\
{[\mathbf{b a r}]}\end{array}$ \\
\hline Taxi & 0 & 1,01 & 1,01 & 0,000 \\
Decolagem & 0 & 1,01 & 1,01 & 0,000 \\
Subida & 1250 & 0,87 & 0,98 & 0,143 \\
Subida & 2499 & 0,75 & 0,96 & 0,180 \\
Subida & 3749 & 0,64 & 0,93 & 0,195 \\
Subida & 4999 & 0,54 & 0,90 & 0,198 \\
Subida & 6248 & 0,46 & 0,88 & 0,193 \\
Subida & 7498 & 0,38 & 0,85 & 0,187 \\
Subida & 8748 & 0,32 & 0,82 & 0,182 \\
Subida & 9997 & 0,26 & 0,80 & 0,176 \\
Subida & 11247 & 0,22 & 0,78 & 0,171 \\
Cruzeiro & 12497 & 0,18 & 0,75 & 0,166 \\
Descida & 11247 & 0,22 & 0,78 & 0,171 \\
Descida & 9997 & 0,26 & 0,80 & 0,176 \\
Descida & 8748 & 0,32 & 0,82 & 0,182 \\
Descida & 7498 & 0,38 & 0,85 & 0,187 \\
Descida & 6248 & 0,46 & 0,88 & 0,193
\end{tabular}




\begin{tabular}{ccccc}
\hline Fase de Voo & $\begin{array}{c}\text { Altitude } \\
{[\mathbf{m}]}\end{array}$ & $\begin{array}{c}\text { Pressão ambiente } \mathbf{P}_{\mathbf{a}} \\
{[\mathbf{b a r}]}\end{array}$ & $\begin{array}{c}\text { Pressão de cabine }-\mathbf{P}_{\mathbf{c}} \text { Vazão para pressurização - D } \\
{[\mathbf{b a r}]}\end{array}$ \\
\hline Descida & 4999 & 0,54 & 0,90 & 0,198 \\
Descida & 3749 & 0,64 & 0,93 & 0,195 \\
Descida & 2499 & 0,75 & 0,96 & 0,180 \\
Descida & 1250 & 0,87 & 0,98 & 0,143 \\
Aproximação e & 0 & 1,01 & 1,01 & 0,000 \\
Pouso & 0 & 1,01 & 1,01 & 0,000 \\
Taxi & 0 & &
\end{tabular}

8.1.2. Requisitos de ar para o dimensionamento do sistema de antigelo

Os requisitos de ar para o sistema de proteção contra gelo devem levar em consideração a formação de gelo e a carga térmica para as regiões protegidas durante a pior condição de formação de gelo (ESTADOS UNIDOS DA AMÉRICA, 2010; EUROPA, 2007; BRASIL, 2009).

\subsubsection{Fatores externos que afetam os requisitos térmicos}

\subsection{Captura de água e limites de incidência}

Os parâmetros mais relevantes relacionados com o crescimento de gelo nas superfícies das aeronaves são o conteúdo de água na fase líquida LWC $\left(\mathrm{mg} / \mathrm{m}^{3}\right)$ e a eficiência de coleta local $\beta$ definida como:

$$
\beta=\frac{d y}{d s}
$$

Onde,

$d y$ : elemento de distância no escoamento sobre o aerofólio

$d s$ : elemento de distância na superfície do aerofólio

mostrados na Figura 8.5.

Neste caso $\beta$ é uma função do: 
- tamanho da gota;

- densidade do ar;

- velocidade do ar;

- forma da gota.

Os limites de incidência de água são dados pelas variáveis $S_{U}$ e $S_{L}$ mostradas na Figura 8.5. A variável $S_{U}$ é definida pela distância do ponto de estagnação do escoamento até o limite superior de impacto das gotas com o aerofólio. Por outro lado, a variável $\mathrm{S}_{\mathrm{L}}$ define a distância do ponto de estagnação até o limite inferior do aerofólio que apresenta impacto com gotas. A Figura 8.6 mostra uma distribuição típica da eficiência de coleta local para um aerofólio.

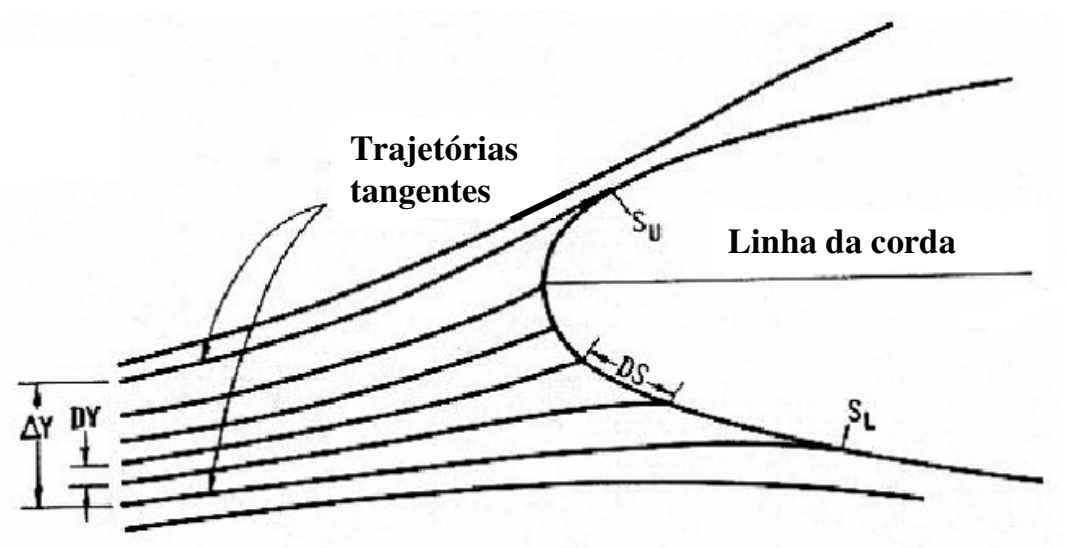

Figura 8.5: Definição dos parâmetros usados na análise do problema. 


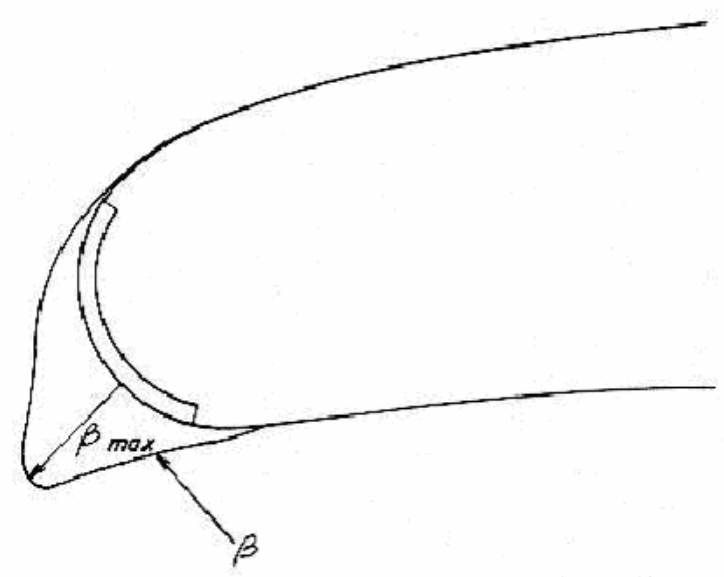

Figura 8.6: Distribuição típica da eficiência de coleta local $\beta$ sobre a borda de ataque de um perfil de asa.

A equação para o cálculo da quantidade total de água capturada é:

$$
M=L W C * V_{\infty} * E^{*} \psi
$$

Onde,

$L W C$ : conteúdo de água na nuvem

$\psi$ : eficiência total de coleta de água

$E$ : espessura máxima do aerofólio

$V_{\infty}$ : velocidade do avião com relação ao ar

$S l$ : distância do ponto de estagnação até o limite de impacto inferior do aerofólio

$S u$ : distância do ponto de estagnação até o limite de impacto superior do aerofólio

$$
\psi=\frac{1}{(S u+S l)} \int_{-S_{l}}^{S_{u}} \beta d s
$$


Para um determinado tamanho mediano de gotas, temperatura ambiente e altitude, a eficiência de coleta de água é uma função da velocidade, forma do aerofólio e espessura.

Os parâmetros de captura de água de um corpo podem ser determinados experimentalmente num túnel de vento ou teoricamente utilizando programas computacionais específicos, como os desenvolvidos pelo ONERA ou NASA, que avaliam o acúmulo de gelo sobre o perfil do avião para determinada condição atmosférica. A análise pode ser bidimensional ou tridimensional e tem como saídas os limites de incidência de água, eficiência de coleta de água, distribuição de pressão no aerofólio, perfil do aerofólio após incidência de água com a respectiva formação de gelo.

\subsection{Coeficiente externo de transferência de calor}

Outro fator que afeta os requisitos térmicos é o coeficiente externo de transferência de calor. O cálculo dos coeficientes de transferência de calor locais requer conhecimento das distribuições de velocidade, pressão estática e temperatura ao redor do aerofólio. Os coeficientes de transferência de calor são avaliados assumindo que os coeficientes laminares locais de um aerofólio são os mesmos que encontrados numa cunha à mesma distância do ponto de estagnação, considerando os mesmos gradientes de velocidade ao longo dos corpos. Os coeficientes de transferência de calor para escoamento turbulento são avaliados pela teoria da placa plana, usando velocidades locais. Considerando ar a temperatura normal, tem-se (SAE, 1990b), em unidades do sistema internacional:

$$
h=0,1234\left(T_{m}\right)^{0,3} \frac{\left[(\rho g)_{a r} V_{\infty}\right]^{0,8}}{d^{0,2}}
$$


Onde,

$h$ : coeficiente turbulento de transferência de calor local

$T_{m}$ : temperatura média entre parede e fluido

$(\rho g)_{a r}:$ peso específico do ar

$d$ : distância superficial até o ponto de estagnação.

A transição do escoamento laminar para o escoamento turbulento depende de gradientes de pressão locais e número de Reynolds local. Na ausência de altos gradientes de pressão, a transição começa quando o número de Reynolds local vale $0,5.10^{6}$ e termina em 2,0.10 ${ }^{6}$ (SAE, 1990b). Um forte gradiente de pressão favorável (pressão estática decrescente com aumento da distância da borda de ataque) atrasa a transição. De modo oposto, um gradiente de pressão desfavorável (pressão estática crescente com aumento da distância da borda de ataque) promove a transição. Os limites de incidência aparentemente não possuem efeitos na transição numa superfície protegida contra gelo. Uma superfície com gelo sempre vai apresentar regime turbulento desde o ponto de estagnação devido às protuberâncias da formação do gelo.

Por outro lado, em termos práticos o coeficiente médio de transferência de calor é mais útil para a análise em questão. As curvas médias de transferência de calor são baseadas no escoamento totalmente turbulento sobre uma placa plana. Tratando este assunto por meio dessa analogia, não é possível levar em consideração o efeito da curvatura do aerofólio ou ângulo de ataque. Entretanto, é provável que estes efeitos estejam dentro dos limites de precisão da fórmula usada. A equação para o coeficiente médio de transferência de calor a uma distância d da borda de ataque é, em unidades do sistema internacional: 


$$
h_{m}=0,1549\left(T_{m}\right)^{0,3} \frac{\left[(\rho g)_{a r} V_{\infty}\right]^{0,8}}{d^{0,2}}
$$

Obs: 1) usualmente d equivale a $19 \%$ da corda, que é a distância a ser protegida do aerofólio. 2) faz-se o cálculo usando d (1) = S, o que resulta num cálculo de potência por área pois é considerada uma distância linear de envergadura.

\subsubsection{2. $\quad$ Fator de molhabilidade}

Este fator (F) é uma medida da área superficial na qual ocorre a evaporação, e está

relacionado ao limite de incidência. À frente do limite de incidência, a água (sobre uma superfície aquecida) tende a formar uns filmes sólidos, cujo fator de molhabilidade é unitário. À jusante do limite de incidência a água escorre em pequenas vazões e o fator nesse caso $\mathrm{F}=$ 0,2. Conseqüentemente, o fator $\mathrm{F}$ pode variar de 0,2 a 1,0 de uma maneira geral, dependendo dos limites de incidência. Entretanto, o valor F igual a 0,6 será utilizado para a análise (SAE, 1990b).

\subsubsection{Taxa de evaporação}

Para o sistema de proteção evaporativo, a taxa de evaporação deve ser igual à captura total de água, em unidades do sistema internacional (SAE, 1990b):

$$
M=\frac{0,693 h_{m} S F\left(p_{s k}-p_{\text {agua }}\right)}{\left(p_{\text {amb }}-p_{s k}\right)}
$$

$M$ : captura total de água por unidade de envergadura

$S$ : área de transferência de calor da borda de ataque por unidade de envergadura 
$T_{s k}:$ temperatura externa da borda de ataque da asa

$T_{\text {agua }}:$ temperatura da água na atmosfera

$p_{a m b}:$ pressão estática ambiente

$p_{s k}:$ pressão de saturação do vapor em $T_{s k}$

$p_{\text {agua }}:$ pressão de saturação do vapor em $T_{\text {água }}$

Para $F=0,6$ e reorganizando os termos vem,

$$
\frac{M}{h S}=0,4158 \frac{\left(p_{\text {sk }}-p_{\text {agиa }}\right)}{\left(p_{\text {amb }}-p_{\text {sk }}\right)}
$$

\subsubsection{Carga térmica para antigelo}

Os requisitos térmicos de um sistema de antigelo evaporativo são determinados pela taxa na qual o calor deve ser fornecido para balancear as perdas térmicas na superfície protegida, o que resulta de três processos coexistentes: troca de calor por convecção, evaporação e aquecimento da temperatura da água que atinge o aerofólio $\left(T_{\text {agua }}\right)$ até a temperatura de parede do aerofólio $\left(T_{s k}\right)$. A equação para determinar a carga térmica para o antigelo é dada por:

$$
\frac{q_{\text {gelo }}}{h S}=\left(T_{s k}-T_{\text {aw }}\right)+\left[\frac{M}{h S} C_{\text {ăgиа }}\left(T_{s k}-T_{\text {ăgua }}\right)\right]+\left(\frac{M}{h S} L_{e}\right)
$$

$q_{\text {gelo }}:$ carga térmica para o antigelo

$T_{a w}$ : temperatura adiabática de parede

$T_{s k}:$ temperatura de parede 


$$
\begin{aligned}
& L_{e} \text { : entalpia de vaporização da água } \\
& C_{a g u a} \text { : calor específico da água }
\end{aligned}
$$

Pode-se utilizar um valor constante igual a 2465,6 kJ/kg (SAE, 1990b) para a entalpia de vaporização da água.

\subsubsection{Requisitos de vazão de ar para antigelo}

Para o cálculo da massa de ar insuflada no duto injetor introduz-se um fator de rendimento $(\eta)$ da transferência de calor interna da borda de ataque. Este rendimento pode ser definido como:

$$
\eta=\frac{T_{\text {injetor }}-T_{\text {saida }}}{T_{\text {injetor }}-T_{a w}}
$$

\footnotetext{
Onde,

$T_{\text {injetor }}$ : temperatura do ar na saída do duto injetor de ar

$T_{\text {saida }}:$ temperatura do ar na saída da borda de ataque
}

A diferença de temperatura entre o ar na saída do duto injetor e a temperatura média de exaustão é uma medida do calor transferido à borda de ataque para a proteção contra gelo. Teoricamente, a máxima queda de temperatura do ar no duto injetor é representada pela diferença entre a temperatura do ar na saída do duto e a temperatura de parede adiabática do aerofólio. 
Os valores de rendimento definidos acima foram obtidos por meio de dados experimentais de ensaios em voo (GANDOLFI, 2004). Foram tomadas medidas de temperatura de ar na saída do duto injetor, na entrada da canaleta interna da asa (exaustão do ar da borda de ataque) e temperaturas de parede adiabáticas. A média dos valores calculados indica um rendimento aproximado de 54\%, que foi adotado nos cálculos.

A massa de ar insuflada no duto injetor para proteção do aerofólio é calculada levando em conta o rendimento anterior:

$$
\dot{m}_{\text {injetor }}=\frac{\dot{Q}_{\text {gelo }}}{\eta C_{p}\left(T_{\text {injetor }}-T_{a w}\right)}
$$

$$
\begin{aligned}
& \text { Onde, } \\
& C_{p} \text { : calor específico do ar } \\
& \dot{m}_{\text {injetor }}: \text { massa de ar insuflada no duto injetor por unidade de envergadura }
\end{aligned}
$$

A simulação foi feita tomando três perfis da asa e três perfis da empenagem horizontal, calculando a massa de ar insuflada para cada perfil e por fim obtendo um valor médio do ar insuflado dos perfis. Em seguida, multiplica-se o valor obtido por meia envergadura da asa e por meia envergadura da empenagem horizontal, obtendo-se assim a quantidade de ar requerida pelo sistema de antigelo para meia asa e meia empenagem horizontal. O mesmo procedimento foi realizado para a entrada de ar do motor que também é protegido, entretanto, nesse caso usaram-se dados de um perfil médio representativo para toda a entrada de ar. A Tabela 8.5 mostra os principais resultados da análise dos requisitos de 
antigelo da asa, estabilizador e entrada do motor na condição crítica de formação de gelo conforme procedimento exposto na seção 8.1.2. 
Tabela 8.5: Resultados para cálculo dos requisitos de antigelo da asa, empenagem e entrada do motor na condição crítica de formação de gelo.

\begin{tabular}{|c|c|c|c|c|c|c|c|}
\hline \multirow[t]{2}{*}{ Dados de entrada } & \multicolumn{3}{|c|}{ Asa } & \multicolumn{3}{|c|}{ Empenagem } & \multirow{2}{*}{$\frac{\text { Entrada de ar do motor }}{\text { Seção }}$} \\
\hline & \multicolumn{6}{|c|}{ Seção 1 Seção 2 Seção 3 Seção 1 Seção 2 Seção 3} & \\
\hline Altitude de voo $[\mathrm{m}]$ & 4572 & 4572 & 4572 & 4572 & 4572 & 4572 & 4572 \\
\hline delta ISA & 10 & 10 & 10 & 10 & 10 & 10 & 10 \\
\hline Velocidade de voo $-V_{\infty}[\mathrm{m} / \mathrm{s}]$ & 131,2 & 131,2 & 131,2 & 131,2 & 131,2 & 131,2 & 131,2 \\
\hline Espessura máxima do aerofólio - E [m] & 0,522 & 0,256 & 0,106 & 0,178 & 0,136 & 0,093 & 0,331 \\
\hline Conteúdo de água na nuvem - LWC [g/m3] & 0,49 & 0,49 & 0,49 & 0,49 & 0,49 & 0,49 & 0,49 \\
\hline Diâmetro médio da gota na nuvem [mícron] & 20 & 20 & 20 & 20 & 20 & 20 & 20 \\
\hline Corda média do aerofólio $-\mathrm{c}_{\mathrm{m}}[\mathrm{m}]$ & 3,959 & 2,204 & 1,098 & 1,790 & 1,467 & 1,142 & 0,905 \\
\hline Eficiência total de coleta de água - $\psi$ & 0,06 & 0,06 & 0,06 & 0,09 & 0,09 & 0,09 & 0,05 \\
\hline $19 \%$ da corda $-\mathrm{d}[\mathrm{m}]$ & 0,752 & 0,419 & 0,209 & 0,340 & 0,279 & 0,217 & 0,172 \\
\hline Fator de Molhabilidade - F & 0,6 & 0,6 & 0,6 & 0,6 & 0,6 & 0,6 & 0,6 \\
\hline Temperatura do ar no saída do duto injetor $-\mathrm{T}_{\text {injetor }}[\mathrm{K}]$ & 493,0 & 493,0 & 493,0 & 493,0 & 493,0 & 493,0 & 533,0 \\
\hline Rendimento da transferência de calor interna da borda de ataque - $\eta$ & 0,54 & 0,54 & 0,54 & 0,54 & 0,54 & 0,54 & 0,54 \\
\hline \multirow[t]{2}{*}{ Dados calculados } & \multicolumn{3}{|c|}{ Asa } & \multicolumn{3}{|c|}{ Empenagem } & Entrada de ar do motor \\
\hline & \multicolumn{6}{|c|}{ Seção 1 Seção 2 Seção 3 Seção 1 Seção 2 Seção 3} & Seção \\
\hline Peso específico do ar - $(\rho g)_{a r}[\mathrm{~N} / \mathrm{m} 3]$ & 7,28 & 7,28 & 7,28 & 7,28 & 7,28 & 7,28 & 7,28 \\
\hline Captura total de água - M [g/s.m de envergadura $]$ & 2,02 & 0,99 & 0,41 & 1,03 & 0,79 & 0,54 & 1,07 \\
\hline Temperatura externa da borda de ataque da asa $-\mathrm{T}_{\mathrm{sk}}[\mathrm{K}]$ & 291,1 & 288,2 & 284,7 & 290,7 & 289,4 & 287,3 & 298,2 \\
\hline Temperatura da água na atmosfera $-\mathrm{T}_{\text {água }}[\mathrm{K}]$ & 268,4 & 268,4 & 268,4 & 268,4 & 268,4 & 268,4 & 268,4 \\
\hline Mach & 0,40 & 0,40 & 0,40 & 0,40 & 0,40 & 0,40 & 0,40 \\
\hline Temperatura adiabática de parede $-\mathrm{T}_{\mathrm{aw}}[\mathrm{K}]$ & 276,1 & 276,1 & 276,1 & 276,1 & 276,1 & 276,1 & 276,1 \\
\hline Coeficiente médio de transferência de calor $-\mathrm{h}_{\mathrm{m}}\left[\mathrm{W} / \mathrm{m}^{2} \mathrm{~K}\right]$ & 215,5 & 241,9 & 277,6 & 252,6 & 262,6 & 275,8 & 290,6 \\
\hline Temperatura média entre parede e fluido $-\mathrm{T}_{\mathrm{m}}[\mathrm{K}]$ & 281,5 & 280,0 & 278,2 & 281,3 & 280,6 & 279,6 & 285,0 \\
\hline Pressão de saturação do vapor a $\mathrm{T}_{\mathrm{sk}}-\mathrm{p}_{\mathrm{sk}}[\mathrm{bar}]$ & 0,0206 & 0,0171 & 0,0136 & 0,0201 & 0,0185 & 0,0162 & 0,0318 \\
\hline Pressão de saturação do vapor a $\mathrm{T}_{\mathrm{w}}-\mathrm{p}_{\mathrm{w}}[\mathrm{b} a r]$ & 0,0041 & 0,0041 & 0,0041 & 0,0041 & 0,0041 & 0,0041 & 0,0041 \\
\hline Pressão estática ambiente - $\mathrm{p}_{\mathrm{amb}}$ [bar] & 0,5718 & 0,5718 & 0,5718 & 0,5718 & 0,5718 & 0,5718 & 0,5718 \\
\hline Carga térmica para o antigelo por unidade de envergadura - Q $[\mathrm{W} /(\mathrm{m})]$ & 7600 & 3750 & 1536 & 3894 & 2985 & 2043 & 3868 \\
\hline Vazão de ar por unidade de envergadura - $\mathrm{m}_{\text {injetor }}[\mathrm{kg} /(\mathrm{s} . \mathrm{m})]$ & 0,064 & 0,032 & 0,013 & 0,033 & 0,025 & 0,017 & 0,028 \\
\hline Densidade de potência $\left[\mathrm{W} / \mathrm{cm}^{2}\right]$ & 1,010 & 0,895 & 0,736 & 1,145 & 1,071 & 0,942 & 2,249 \\
\hline Envergadura/tamanho linear da entrada do motor $[\mathrm{m}]$ & & 8,880 & & & 3,775 & & 3,386 \\
\hline Vazão de ar média por semi asa, semi empenagem e um motor $-\mathrm{m}_{\text {injetor_m }}[\mathrm{kg} / \mathrm{s}]$ & & 0,322 & & & 0,095 & & 0,093 \\
\hline
\end{tabular}




\subsection{Sistemas Convencionais}

Após o cálculo dos requisitos de potência que dimensionam os sistemas, devem-se calcular os principais parâmetros termodinâmicos dos sistemas na condição de voo típica para realizar a análise exergética. Sendo assim, descreve-se nesta seção as considerações e abordagens envolvidas na modelagem dos sistemas convencionais.

\subsubsection{Motor}

O modelo do motor foi confeccionado com o auxílio do simulador GSP - "Gas Turbine Simulation Program" (NRL, 2005). Este simulador foi criado pelo departamento aeroespacial da TUDelft - "Delft University of Technology" em 1986, mas seu desenvolvimento continuou no NRL - "National Aerospace Laboratory" na Holanda.

GSP é implementado em Borland Delphi ${ }^{\mathrm{TM}}$ em um ambiente orientado a objeto. Podem-se realizar simulações em regime permanente ou transitório de qualquer configuração de turbina a gás, pelo estabelecimento de um arranjo específico dos componentes da turbina. GSP é usado para a análise de sensibilidade de variáveis como condições ambientais do voo, perdas de instalação, algum defeito do motor (incluindo mau funcionamento do sistema de controle), deterioração de componentes e emissões de gases de escape.

A simulação de uma turbina a gás com GSP se baseia na modelagem adimensional dos processos nos vários componentes da turbina por meio de expressões aerotermodinâmicas e da caracterização do estado estacionário (mapas dos componentes).

Com a modelagem adimensional, nos procedimentos de cálculo são utilizadas as propriedades médias termodinâmicas do ar e do gás na seção de passagem dos fluxos (de entrada e saída de cada componente).

O modelo do motor é criado colocando diferentes componentes predefinidos (como coletores, compressores, câmaras de combustão, turbinas e bocais de descarga) na 
configuração correspondente do motor específico que se quer simular. As condições do gás que sai de um componente representam as condições de entrada do componente seguinte.

Os vários equipamentos se encontram em bibliotecas: a biblioteca de componentes padrão ("gas path standard component library") que permite montar os modelos e a biblioteca padrão de componentes de controle ("standard control component library") que contém sistemas de controle genéricos (vide Figura 8.7).

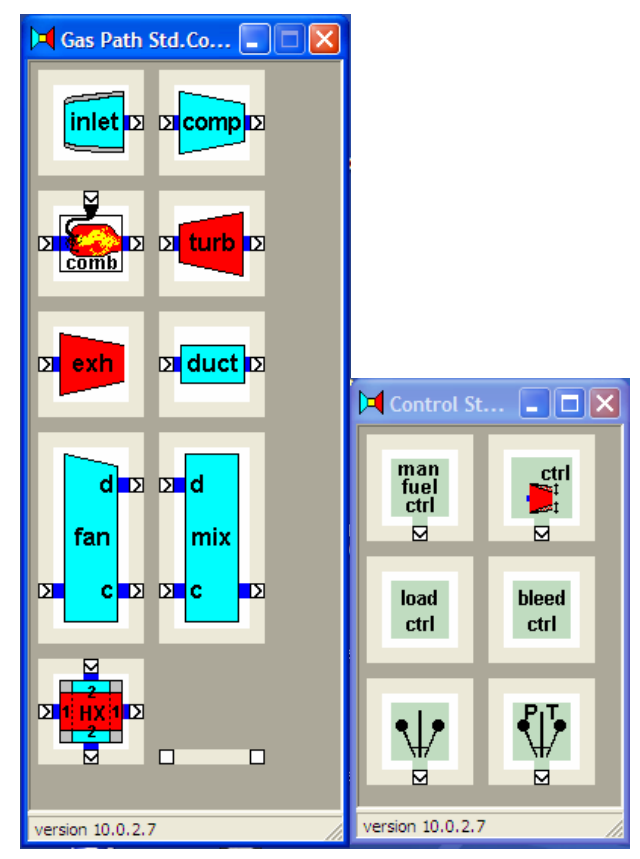

Figura 8.7: "Gas path standard component library"e "Standard control component library" do simulador GSP.

Os processos em cada componente da turbina são determinados por meio de relações entre certos parâmetros definidos mediante os mapas dos componentes e equações termodinâmicas. Estes parâmetros são as propriedades do ar, do gás, as rotações, as eficiências, e outros que determinam a condição de funcionamento dos componentes.

Para utilizar o GSP, primeiramente é preciso definir um ponto de projeto por meio dos dados especificados pelo usuário. Os pontos fora de projeto são calculados resolvendo um conjunto de equações diferenciais não lineares. As equações utilizadas pelo programa para definir o desempenho do motor e as variações das condições do gás que passa pelos vários componentes são: 
- equações de conservação da massa;

- equações de conservação da energia;

- equações dos gases perfeitos;

- equações do fluxo isentrópico;

- equações de conservação do momento do fluxo do gás;

- equações do efeito da inércia do rotor;

- equações de transferência do calor entre o gás e as paredes do motor.

A maior parte dos equipamentos utiliza mapas para representar as características dos componentes multidimensionais e não lineares. Estes mapas são salvos em arquivos de texto e precisam ser importados em cada componente na fase de construção do modelo. Mapas fora de projeto devem ser utilizados para a modelagem do ventilador, do compressor, dos trocadores de calor das turbinas, do bocal de descarga, do coletor dinâmico e da câmara de combustão.

A modelagem do motor seguiu as seguintes fases conceituais (como esquematizado na Figura 8.8):

1. Construção do motor utilizando a biblioteca de componentes padrão;

2. Colocação dos sistemas de controle do combustível, das extrações de ar do ventilador e do compressor e das extrações de potência dos eixos utilizando a biblioteca padrão de componentes de controle;

3. Estabelecimento das condições atmosféricas e de voo no ponto de projeto (velocidade, altitude, temperatura ambiente);

4. Simulação do ponto de projeto;

5. Estabelecimento de uma tabela com as condições atmosféricas e de voo nos pontos fora de projeto (velocidade, altitude, temperatura ambiente, tempo de voo);

6. Simulação das condições fora do ponto de projeto; 


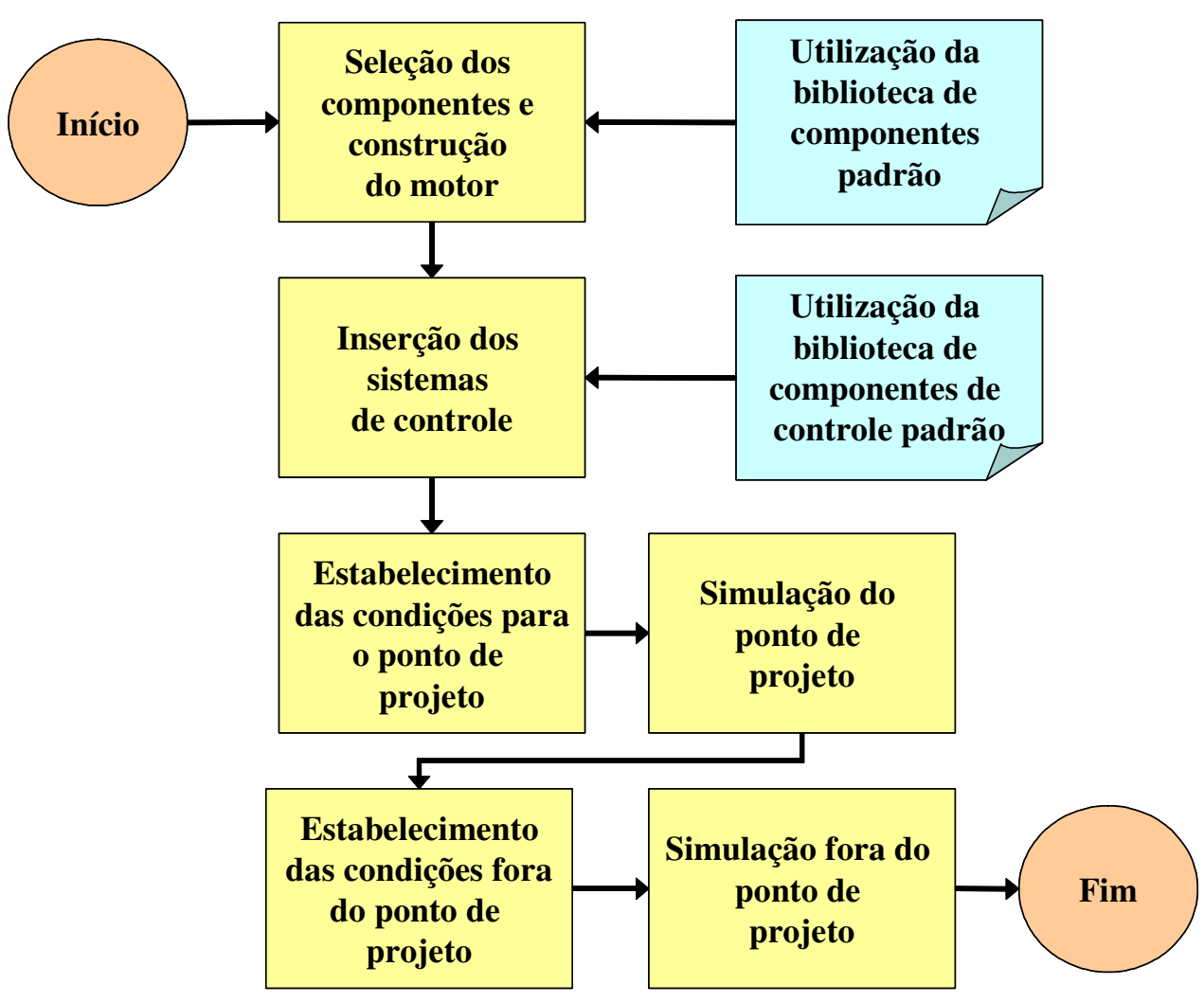

Figura 8.8: Esquema das fases conceituais da modelagem do motor.

Como se pode ver na Figura 8.9 o modelo foi criado colocando um coletor dinâmico e em seguida um ventilador. O motor é um turbo jato com fluxos misturados e grande taxa de derivação, com duto do fluxo secundário extenso até o bocal de descarga. O motor possui um fluxo externo que passa por um duto cuja representação é um componente chamado "duct", utilizado para modelar as perdas de pressão e depois é misturado ao fluxo interno no misturador ("mixer"). O fluxo interno é comprimido novamente no compressor e depois passa pela câmara de combustão que simula todos os processos de combustão primária e geração de gás (processos químicos, perdas de pressão, transferência de calor, emissões poluentes). $\mathrm{Na}$ saída da câmara de combustão é inserida uma turbina de alta pressão e, em seguida, uma de baixa pressão, modeladas por meio de dois diferentes componentes. $\mathrm{O}$ componente turbina ("turbine component") é utilizado para obter potência mecânica dos gases de descarga e movimentar um eixo. São inseridos dois eixos, um para a turbina de alta pressão ligado ao compressor e outro para a turbina de baixa pressão ligado ao ventilador. Depois da turbina de baixa pressão é utilizando outro duto para simular perdas de pressão, e o fluxo em seguida é misturado ao secundário no misturador. 


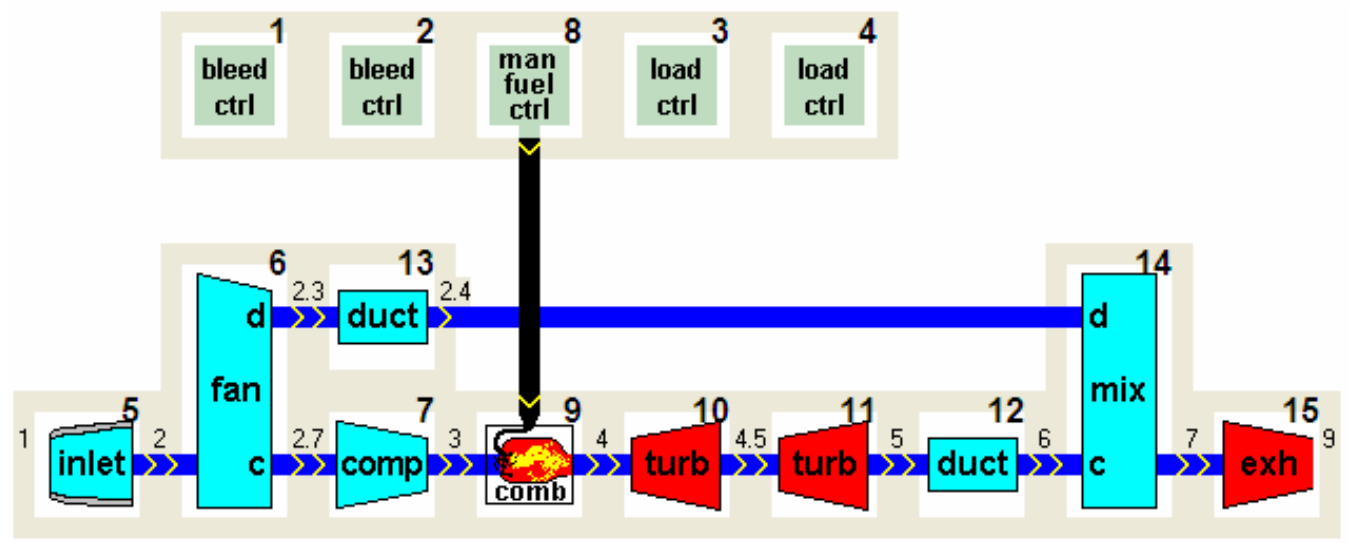

Figura 8.9: Modelo completo do motor para o avião com sistemas convencionais.

Neste modelo não são inseridos controles das forças aplicadas aos eixos, mas é previsto o controle manual de injeção de combustível, permitindo definir o fluxo na entrada da câmara de combustão nas condições fora do ponto de projeto. Com o controle manual o fluxo de combustível pode ser especificado numa condição de fora do ponto de projeto com dados especificados pelo usuário.

Em um motor aeronáutico normalmente estão presentes numerosas extrações de ar como:

- extrações do ventilador para os sistemas de gerenciamento de ar;

- extrações do compressor para os sistemas de gerenciamento de ar;

- extrações do compressor para o resfriamento da turbina.

O modelo criado simula extrações variáveis no ventilador e no compressor nas diferentes fases de voo, por este motivo são incluídos dois controles de sangria ("bleed control"): um para o compressor e outro para o ventilador. Em particular, no compressor podem-se distinguir diferentes condições de extração devido aos requisitos dos consumidores do sistema de gerenciamento de ar:

- ar condicionado e antigelo ligados : extração no estágio final do compressor, quando o motor está em regime de baixa tração; extração em estágio intermediário do compressor, quando o motor está em regime de alta tração;

- ar condicionado ligado e antigelo desligado : extração no estágio final do compressor, quando o motor está em regime de baixa tração; extração em estágio intermediário do compressor, quando o motor está em regime de alta tração; 
O controle das extrações de ar do compressor permite uma regulagem das mesmas, seja em condições de projeto ou não. Os parâmetros que precisam ser definidos para a modelagem do controle de extrações são:

- Vazões de ar extraído do compressor e do ventilador na condição de ponto de projeto ;

- Vazões de ar extraído do compressor e do ventilador nas condições fora de ponto de projeto;

- Fração de entalpia extraída (variável FracH).

O parâmetro FracH indica quanto do aumento de entalpia fornecido pelo compressor ao ar é fornecido também ao ar extraído. Em outras palavras o FracH representa em qual ponto do compressor entre a saída $(\mathrm{FracH}=1)$ e a entrada $(\mathrm{FracH}=0)$ é extraído o ar.

Além das extrações de ar, o motor possui também extrações de potência mecânica do eixo. No modelo são incluídos dois sistemas de controle da potência extraída ("load control") para poder definir a potência necessária para a alimentação da bomba hidráulica e do gerador elétrico. As duas extrações mecânicas são realizadas no eixo de menor rotação.

Além disso, precisam ser definidas as condições de projeto (por meio do número de Mach, da velocidade real ou calibrada), a densidade e eventualmente a umidade do ar.

\subsubsection{Definição do ponto de projeto}

No cálculo do ponto de projeto não se utilizam os mapas dos componentes, mas são calculados os fatores de escala necessários para obter os mapas corretos em relação aos fornecidos pelo programa. O cálculo do ponto de projeto é sempre necessário antes de calcular outros pontos em regime permanente ou transiente, visto que o ponto de projeto é usado como referência para os cálculos dos outros pontos.

Detalhes do ponto de projeto:

- Condição de voo cruzeiro com antigelo desligado;

- Altitude: 11277 m;

- Mach: 0,77; 
- Empuxo: $9000 \mathrm{~N}$;

- Vazão de ar extraída do ventilador: 0,084 kg/s;

- Pressão de extração do ventilador: 0,45 bar;

- Temperatura de extração do ventilador: $269,9 \mathrm{~K}$;

- Vazão de ar extraída do compressor: 0,190 kg/s;

- Estágio de extração do compressor: intermediário

- Pressão de extração do compressor: 3,35 bar;

- Temperatura de extração do compressor: 478,6 K;

- Potência extraída do eixo de menor rotação: 15 kW;

- Rotação do compressor: 14600 rpm;

- Rotação do ventilador: 8000 rpm;

- Temperatura dos gases entre as turbinas de alta e de baixa pressão: 1036,1 K;

- Consumo de combustível: $0,1695 \mathrm{~kg} / \mathrm{s}$.

\subsubsection{Modelagem das condições fora do ponto de projeto}

Depois ter definido o ponto de projeto, podem ser realizadas simulações em outros pontos, tanto estacionárias quanto transitórias. O modelo criado considera a condição de cruzeiro como ponto de projeto e modela as condições de decolagem, subida, descida e pouso como estados estacionários fora do ponto de projeto. Os detalhes das configurações fora de projeto podem ser definidos mudando as condições de voo (velocidade, altitude e extrações) considerando a real pressão na altitude de voo.

O desempenho fora de projeto é calculado por meio de equações (como as simples equações das perdas de pressão) e utiliza as características dos componentes que em certos casos são representadas por meio de mapas (ventilador, compressor e da turbina).

\subsubsection{Sistemas de extração pneumática e sistema de controle ambiental}

No avião convencional, o controle de temperatura e pressão do ar distribuído aos consumidores é realizado pelo sistema pneumático, que é formado pelos pórticos de extração de ar do motor (dois estágios no compressor e um estágio no ventilador), válvulas reguladoras de pressão e de corte a jusante dos pórticos, pré-resfriador, válvulas reguladoras de pressão 
localizadas a montante da UCA e dos sistemas de antigelo das asas e estabilizadores (Figura $8.10)$.

O principal componente do sistema de controle ambiental é a UCA, que é uma máquina de ar condicionado ciclo ar. Nesse caso, o ar é expandido na turbina e a potência de eixo gerada alimenta um compressor e um ventilador, convertendo entalpia em trabalho. O fluido de trabalho (o próprio ar) é quem promove simultaneamente o resfriamento, ventilação e a pressurização da cabine. Quanto maior a razão de pressão na turbina de expansão da unidade de controle ambiental, maior é o efeito de resfriamento obtido. Em contrapartida, maior deve ser a entalpia do ar sangrado dos motores e assim maior os impactos em consumo de combustível. O desempenho padrão de uma UCA com três rodas foi considerado idêntico nas análises dos aviões convencional e mais elétrico.

\subsubsection{Sistema de extração pneumática}

As pressões consideradas na entrada do sistema pneumático, estado "1C", variam com o regime do motor e seleção do pórtico de extração, conforme mencionado na seção 8.2.1. Considera-se que a temperatura do estado " $2 \mathrm{C}$ " é a mesma da temperatura do estado " $1 \mathrm{C}$ ", utilizando a hipótese que as válvulas reguladoras de pressão a jusante dos pórticos são perfeitamente isoladas. Como o encaminhamento dos dutos da tubulação de sistemas de antigelo geralmente é feito em regiões próximas ao tanque de combustível, deve-se regular a temperatura do ar do sistema de extração pneumática em níveis seguros e assim evitar a auto ignição do combustível. A temperatura regulada no pré-resfriador " $\mathrm{T}_{3 \mathrm{C}}$ " é considerada $220^{\circ} \mathrm{C}$ em todas as fases de voo; com exceção do regime do motor de aproximação e pouso no qual a temperatura do ar extraído do compressor já está abaixo daquele valor. Essa temperatura é adequada para cumprir com o requisito de flamabilidade de combustível conforme especificado na AC 25.981-1B, e assim eliminar o risco de explosão nos tanques de combustível.

O cálculo do calor rejeitado no pré-resfriador é dado pela equação (101).

$$
\dot{Q}_{P R}=\dot{m}_{\text {ar_compressor }} C_{P}\left(T_{2 C}-T_{3 C}\right)=\dot{m}_{\text {ar_ventilador }} C_{P}\left(T_{2 V}-T_{1 V}\right)
$$


Sabendo-se que no pré-resfriador a capacidade térmica do lado quente é menor ou igual à capacidade térmica do lado frio (CONCEIÇÃO, 2006), a efetividade na qual o préresfriador opera é obtida pela equação (102).

$$
\varepsilon_{P R}=\frac{\left(T_{2 C}-T_{3 C}\right)}{\left(T_{2 C}-T_{1 V}\right)}
$$

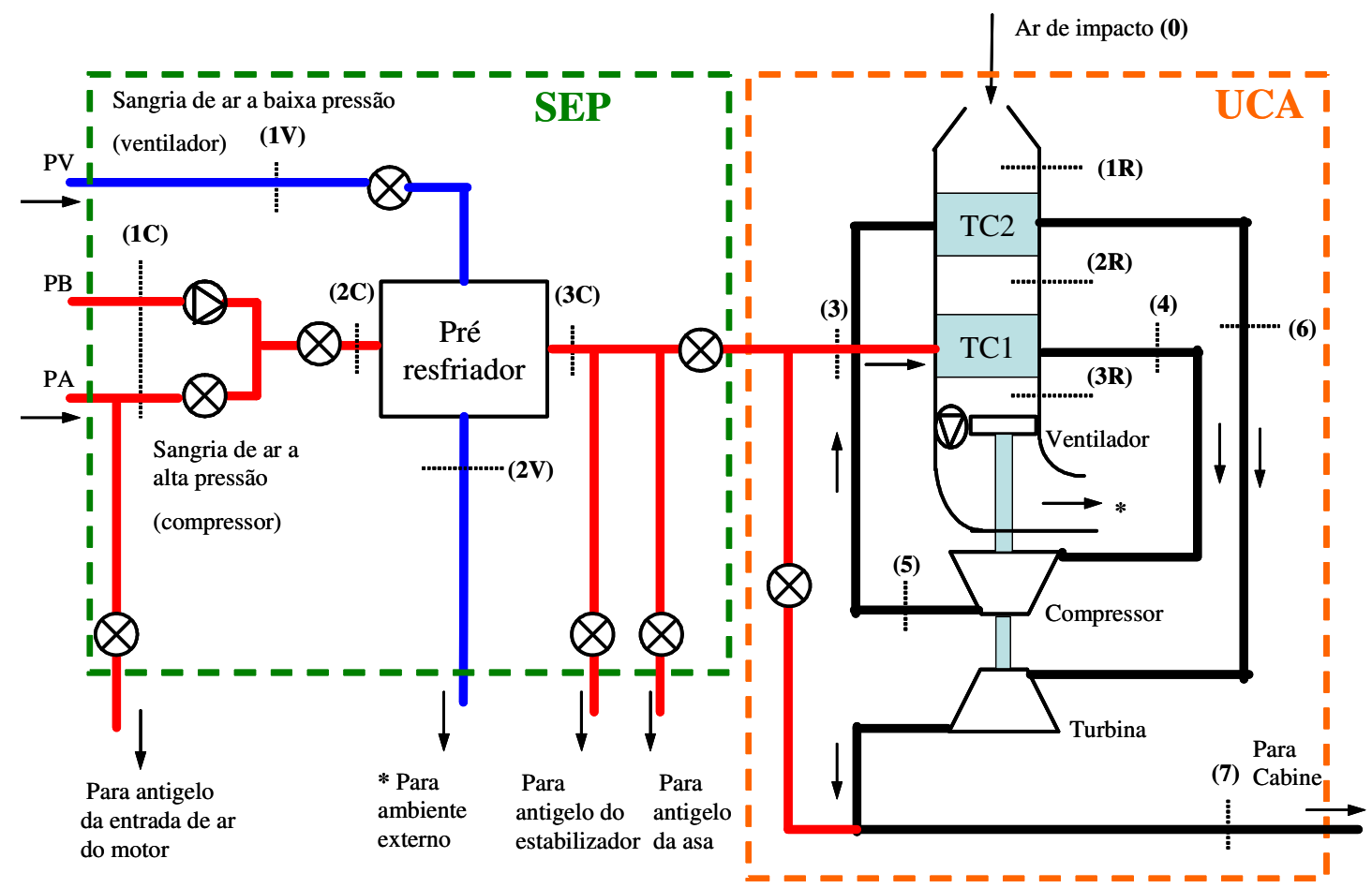

Figura 8.10: Esquema do sistema de extração pneumática (SEP) e unidade de controle ambiental (UCA).

\subsubsection{Unidade de controle ambiental}

A unidade de controle ambiental é dividida em trocador de calor primário (TC1), trocador de calor secundário (TC2), compressor, turbina e ventilador. O objetivo desta seção é descrever os processos e as hipóteses consideradas em cada equipamento da UCA. 


\subsection{Trocadores de calor primário e secundário}

Para calcular as trocas térmicas nos trocadores de calor primário e secundário é preciso conhecer as vazões mássicas que atravessam estes trocadores. Conceição (2006) define o número adimensional $\mathrm{R}$ que é a razão entre a vazão mássica do ar de impacto com a vazão mássica do ar sangrado dos motores que passa pela UCA:

$$
R=\frac{\dot{m}_{a r_{-} i m p a c t o}}{\dot{m}_{a r_{-} U C A}}
$$

O mesmo autor fez um estudo paramétrico sobre a influência desse parâmetro na quantidade de calor trocada nos dois trocadores de calor, além de observar a variação no coeficiente de eficácia da unidade de controle ambiental. Concluiu que, para não violar a Primeira Lei da Termodinâmica, o valor de $\mathrm{R}$ deve ser maior que 1 e, quando o parâmetro atinge o valor 2, a quantidade de calor trocada nos dois trocadores de calor e o coeficiente de eficácia da UCA tornam-se máximos. Sendo assim, considerou-se o valor de R igual a 2 para todos as situações de voo.

As trocas de calor nos trocadores primário e secundário podem ser obtidas por, respectivamente:

$$
\begin{aligned}
& \dot{Q}_{T C 1}=\dot{m}_{a r_{-} U C A} C_{P}\left(T_{3}-T_{4}\right)=\dot{m}_{\text {ar_ } r_{-} \text {impacto }} C_{P}\left(T_{3 R}-T_{2 R}\right) \\
& \dot{Q}_{T C 2}=\dot{m}_{a r_{-} U C A} C_{P}\left(T_{5}-T_{6}\right)=\dot{m}_{\text {ar_impacto }} C_{P}\left(T_{2 R}-T_{1 R}\right)
\end{aligned}
$$

Substituindo a relação (103) nas equações (104) e (105), tem-se as seguintes equações:

$$
C_{P}\left(T_{3}-T_{4}\right)=R \cdot C_{P}\left(T_{3 R}-T_{2 R}\right)
$$




$$
C_{P}\left(T_{5}-T_{6}\right)=R \cdot C_{P}\left(T_{2 R}-T_{1 R}\right)
$$

As temperaturas de saída $\mathrm{T}_{4}$ e $\mathrm{T}_{6}$ dos trocadores podem ser obtidas pelas suas respectivas efetividades. Considerou-se então que as efetividades dos trocadores de calor primário e secundário são iguais a 0,8 (CONCEIÇÃO, 2006), que podem ser definidas pelas equações seguintes pois a vazão mássica da fonte quente é menor que a vazão mássica da fonte fria:

$$
\begin{gathered}
\varepsilon_{T C 1}=\frac{\left(T_{3}-T_{4}\right)}{\left(T_{3}-T_{2 R}\right)} \\
\varepsilon_{T C 2}=\frac{\left(T_{5}-T_{6}\right)}{\left(T_{5}-T_{1 R}\right)}
\end{gathered}
$$

Considerou-se também que as perdas por atrito no interior dos trocadores de calor primário e secundário são nulas (CONCEIÇÃO, 2006). Sendo assim, $\mathrm{P}_{3}$ é igual a $\mathrm{P}_{4}$, e $\mathrm{P}_{5}$ igual a $\mathrm{P}_{6}$.

\subsection{Compressor}

Considerou-se compressão isentrópica com eficiência de 0,82 (CONCEIÇÃO, 2006) constante em todas as fases de voo. A temperatura de saída isentrópica $\mathrm{T}_{5 \mathrm{i}}$ pode ser obtida pela seguinte relação:

$$
\frac{T_{5 i}}{T_{4}}=\left(\frac{p_{5}}{p_{4}}\right)^{\frac{\gamma-1}{\gamma}}
$$

Utilizando-se a eficiência isentrópica do compressor ( $\left.\eta_{\text {comp_UCA }}\right)$, pode-se obter temperatura de saída $\left(\mathrm{T}_{5}\right)$ e trabalho do compressor $\left(\mathrm{W}_{\text {comp_UCA }}\right)$ pelas equações abaixo. 


$$
\begin{gathered}
\eta_{\text {comp_UCA }_{-}}=\frac{T_{5 i}-T_{4}}{T_{5}-T_{4}} \\
\dot{W}_{c o m p_{-} U C A}=\dot{m}_{a r_{-} U C A} C_{P}\left(T_{5}-T_{4}\right)
\end{gathered}
$$

\subsection{Turbina}

Semelhante à abordagem da compressão, considerou-se compressão isentrópica com eficiência de 0,77 (CONCEIÇÃO, 2006) constante em todas as fases de voo. A pressão $\mathrm{P}_{7}$ é ligeiramente maior que a pressão no interior da cabine devido às perdas inerentes do sistema de distribuição de ar de baixa pressão. Desprezaram-se tais perdas considerando a pressão $\mathrm{P}_{7}$ igual à pressão de cabine. A temperatura de saída isentrópica $\mathrm{T}_{7 \mathrm{i}}$ pode ser obtida pela seguinte relação:

$$
\frac{T_{7 i}}{T_{6}}=\left(\frac{p_{7}}{p_{6}}\right)^{\frac{\gamma-1}{\gamma}}
$$

Utilizando-se a eficiência isentrópica da turbina ( $\left.\eta_{\text {turb_UCA }}\right)$, pode-se obter temperatura de saída $\left(\mathrm{T}_{7}\right)$ e trabalho da turbina ( $\left.\mathrm{W}_{\text {turb_UCA }}\right)$.

$$
\begin{gathered}
\eta_{\text {turb_UCA }}=\frac{T_{6}-T_{7}}{T_{6}-T_{7 i}} \\
\dot{W}_{\text {turb_UCA }}=\dot{m}_{a r_{-} U C A} C_{P}\left(T_{6}-T_{7}\right)
\end{gathered}
$$

A pressão na saída do compressor $\left(\mathrm{P}_{5}\right)$ é obtida por meio do balanço de energia da UCA: o trabalho produzido na turbina é igual à soma da potência consumida no compressor e ventilador, desprezando-se as perdas, dado por:

$$
\dot{W}_{\text {turb_UCA }}=\dot{W}_{\text {comp_UCA }}+\dot{W}_{\text {vent_ } U C A}
$$


O uso do ventilador da UCA é restrito a condições em que o avião está parado ou possui baixa velocidade em solo. Em tais condições, o ar externo é direcionado aos trocadores de calor por meio do ventilador pois não há gradiente de pressão favorável na tomada de ar de impacto (Figura 8.10). Em voo, o gradiente de pressão é favorável e o uso do ventilador não é mais necessário, entretanto, o mesmo causa penalidade para a máquina de ar condicionado pois está conectado à turbina. Como simplificação, adotou-se que a potência do ventilador ( $\left.\mathrm{W}_{\text {vent_UCA }}\right)$ é zero nas condições simuladas da missão típica (Figura 7.6 e 7.7).

Os principais resultados do sistema de extração pneumática e UCA são observados na Tabela 8.6 à Tabela 8.11 . 
Tabela 8.6: Vazões mássicas e pressões do SEP e UCA - sistema de antigelo desligado.

\begin{tabular}{|c|c|c|c|c|c|c|c|c|c|}
\hline Fase de Voo & Altitude [m] & $\begin{array}{c}\mathbf{m}_{\text {ar_compressor }} \\
{[\mathrm{kg} / \mathrm{s}]}\end{array}$ & $\begin{array}{c}\mathbf{m}_{\text {ar_ventilador }} \\
{[\mathrm{kg} / \mathrm{s}]}\end{array}$ & $\begin{array}{c}\mathbf{m}_{\mathrm{ar} \_ \text {UCA }} \\
{[\mathrm{kg} / \mathrm{s}]} \\
\end{array}$ & $\begin{array}{c}\mathbf{m}_{\text {ar_impacto }} \\
{[\mathrm{kg} / \mathrm{s}]}\end{array}$ & $\begin{array}{c}\mathbf{p}_{2 \mathrm{C}}=\mathbf{p}_{3 \mathrm{C}} \\
{[\mathrm{bar}]}\end{array}$ & $\begin{array}{l}p_{3}=p_{4} \\
{[b a r]}\end{array}$ & $\begin{array}{l}\mathbf{p}_{5}=\mathbf{p}_{6} \\
{[\mathrm{bar}]}\end{array}$ & $\begin{array}{c}\mathbf{p}_{7} \\
{[\text { bar] }}\end{array}$ \\
\hline 1 - Decolagem & 0 & 0,223 & 0,172 & 0,223 & 0,447 & 7,84 & 3,12 & 6,23 & 1,04 \\
\hline 2 - Subida & 6096 & 0,140 & 0,083 & 0,140 & 0,279 & 4,65 & 2,17 & 3,90 & 0,91 \\
\hline 3 - Subida & 10668 & 0,182 & 0,081 & 0,182 & 0,364 & 2,80 & 1,77 & 3,01 & 0,80 \\
\hline 4 - Cruzeiro & 11277,6 & 0,190 & 0,084 & 0,190 & 0,379 & 2,68 & 1,73 & 2,95 & 0,78 \\
\hline 5 - Cruzeiro & 12496,8 & 0,181 & 0,079 & 0,181 & 0,363 & 2,14 & 1,67 & 2,84 & 0,73 \\
\hline 6 - Descida & 10668 & 0,182 & 0,025 & 0,182 & 0,364 & 3,42 & 1,77 & 3,10 & 0,75 \\
\hline 7 - Descida & 6096 & 0,140 & 0,015 & 0,140 & 0,279 & 4,49 & 2,17 & 4,07 & 0,82 \\
\hline 8 - Espera & 4572 & 0,160 & 0,085 & 0,160 & 0,320 & 4,49 & 2,35 & 4,28 & 0,96 \\
\hline 9 - Aproximação e aterrissagem & 0 & 0,223 & 0,000 & 0,223 & 0,447 & 3,92 & 3,12 & 6,23 & 1,04 \\
\hline
\end{tabular}

Tabela 8.7: Vazões mássicas e pressões do SEP e UCA - sistema de antigelo ligado.

\begin{tabular}{|c|c|c|c|c|c|c|c|c|c|}
\hline Fase de Voo & Altitude [m] & $\begin{array}{c}\mathbf{m}_{\text {ar_compressor }} \\
{[\mathrm{kg} / \mathrm{s}]}\end{array}$ & $\begin{array}{c}\mathbf{m}_{\text {ar_ventilador }} \\
{[\mathbf{k g} / \mathbf{s}]}\end{array}$ & $\begin{array}{c}\mathbf{m}_{\mathrm{ar} \_\mathrm{UCA}} \\
{[\mathrm{kg} / \mathrm{s}]} \\
\end{array}$ & $\begin{array}{c}\mathbf{m}_{\text {ar_impacto }} \\
{[\mathrm{kg} / \mathbf{s}]}\end{array}$ & $\begin{array}{c}\mathbf{p}_{2 \mathrm{C}}=\mathbf{p}_{3 \mathrm{C}} \\
{[\mathrm{bar}]}\end{array}$ & $\begin{array}{l}\mathbf{p}_{3}=\mathbf{p}_{4} \\
{[\mathrm{bar}]}\end{array}$ & $\begin{array}{l}p_{5}=p_{6} \\
{[\text { bar }]}\end{array}$ & $\begin{array}{c}\mathbf{p}_{7} \\
{[\text { bar] }}\end{array}$ \\
\hline 1 - Decolagem & 0 & 0,734 & 0,575 & 0,223 & 0,447 & 7,14 & 3,12 & 6,23 & 1,04 \\
\hline 2 - Subida & 6096 & 0,650 & 0,388 & 0,140 & 0,279 & 3,83 & 2,17 & 3,90 & 0,91 \\
\hline 3 - Subida & 10668 & 0,182 & 0,081 & 0,182 & 0,364 & 2,80 & 1,77 & 3,01 & 0,80 \\
\hline 4 - Cruzeiro & 11277,6 & 0,190 & 0,084 & 0,190 & 0,379 & 2,68 & 1,73 & 2,95 & 0,78 \\
\hline 5 - Cruzeiro & 12496,8 & 0,181 & 0,079 & 0,181 & 0,363 & 2,14 & 1,67 & 2,84 & 0,73 \\
\hline 6 - Descida & 10668 & 0,182 & 0,025 & 0,182 & 0,364 & 3,42 & 1,77 & 3,10 & 0,75 \\
\hline 7 - Descida & 6096 & 0,650 & 0,151 & 0,140 & 0,279 & 3,16 & 2,17 & 4,07 & 0,82 \\
\hline 8 - Espera & 4572 & 0,671 & 0,523 & 0,160 & 0,320 & 8,94 & 2,35 & 4,28 & 0,96 \\
\hline 9 - Aproximação e aterrissagem & 0 & 0,734 & 0,000 & 0,223 & 0,447 & 3,92 & 3,12 & 6,23 & 1,04 \\
\hline
\end{tabular}


Tabela 8.8: Temperaturas do SEP e UCA - sistema de antigelo desligado.

\begin{tabular}{|c|c|c|c|c|c|c|c|c|c|c|c|c|c|c|c|c|}
\hline Fase de Voo & $\begin{array}{c}\text { Altitude } \\
{[\mathrm{m}]}\end{array}$ & $\begin{array}{c}\mathbf{T}_{\mathbf{0}} \\
{[\mathbf{K}]}\end{array}$ & $\begin{array}{l}\mathbf{T}_{1 \mathbf{V}} \\
{[\mathrm{K}]}\end{array}$ & $\begin{array}{l}\mathbf{T}_{2 \mathbf{V}} \\
{[\mathbf{K}]}\end{array}$ & $\begin{array}{l}\mathbf{T}_{1 \mathrm{R}} \\
{[\mathrm{K}]}\end{array}$ & $\begin{array}{l}\mathbf{T}_{2 R} \\
{[\mathbf{K}]}\end{array}$ & $\begin{array}{l}\mathbf{T}_{3 \mathbf{R}} \\
{[\mathbf{K}]}\end{array}$ & $\begin{array}{l}\mathbf{T}_{2 \mathrm{C}} \\
{[\mathbf{K}]}\end{array}$ & $\begin{array}{l}\mathbf{T}_{3 \mathrm{C}} \\
{[\mathbf{K}]}\end{array}$ & $\begin{array}{c}\mathbf{T}_{3} \\
{[\mathbf{K}]}\end{array}$ & $\begin{array}{c}\mathbf{T}_{4} \\
{[\mathbf{K}]}\end{array}$ & $\begin{array}{c}\mathbf{T}_{\mathbf{5}} \\
{[\mathbf{K}]}\end{array}$ & $\begin{array}{r}\mathbf{T}_{5 \mathbf{i}} \\
{[\mathbf{K}]}\end{array}$ & $\begin{array}{l}T_{6} \\
{[K]}\end{array}$ & $\begin{array}{c}\mathbf{T}_{7} \\
{[\mathbf{K}]}\end{array}$ & $\begin{array}{r}\mathbf{T}_{7 \mathbf{i}} \\
{[\mathbf{K}]}\end{array}$ \\
\hline 1 - Decolagem & 0 & 288,2 & 335,4 & 489,7 & 290,2 & 376,9 & 423,4 & 607,0 & 493,0 & 493,0 & 400,1 & 507,0 & 487,8 & 333,6 & 226,0 & 193,9 \\
\hline 2 - Subida & 6096 & 248,5 & 309,9 & 445,7 & 262,9 & 338,4 & 400,3 & 571,0 & 493,0 & 493,0 & 369,3 & 451,7 & 436,9 & 300,7 & 217,9 & 193,2 \\
\hline 3 - Subida & 10668 & 218,8 & 286,5 & 391,4 & 235,8 & 306,4 & 381,0 & 538,2 & 493,0 & 493,0 & 343,7 & 412,3 & 400,0 & 271,1 & 202,2 & 181,6 \\
\hline 4 - Cruzeiro & 11277,6 & 216,7 & 288,5 & 394,2 & 239,5 & 310,0 & 383,2 & 538,3 & 493,0 & 493,0 & 346,6 & 415,8 & 403,4 & 274,8 & 205,3 & 184,5 \\
\hline 5 - Cruzeiro & 12496,8 & 216,7 & 287,7 & 390,1 & 239,5 & 310,0 & 383,2 & 536,0 & 493,0 & 493,0 & 346,6 & 415,8 & 403,4 & 274,8 & 205,3 & 184,5 \\
\hline 6 - Descida & 10668 & 218,8 & 264,9 & 287,3 & 241,9 & 315,1 & 386,2 & 496,0 & 493,0 & 493,0 & 350,6 & 424,8 & 411,4 & 278,5 & 204,0 & 181,8 \\
\hline 7 - Descida & 6096 & 248,5 & 282,0 & 328,6 & 265,5 & 345,5 & 404,5 & 498,0 & 493,0 & 493,0 & 375,0 & 465,3 & 449,1 & 305,5 & 214,6 & 187,5 \\
\hline 8 - Espera & 4572 & 258,4 & 305,9 & 418,8 & 265,8 & 342,4 & 402,6 & 550,7 & 493,0 & 493,0 & 372,5 & 457,3 & 442,0 & 304,1 & 218,9 & 193,4 \\
\hline 9 - Aproximação e aterrissagem & 0 & 288,2 & 296,8 & 296,8 & 290,2 & 371,6 & 407,8 & 462,0 & 462,0 & 462,0 & 389,7 & 493,8 & 475,1 & 330,9 & 226,3 & 195,0 \\
\hline
\end{tabular}

Tabela 8.9: Temperaturas do SEP e UCA - sistema de antigelo ligado.

\begin{tabular}{|c|c|c|c|c|c|c|c|c|c|c|c|c|c|c|c|c|}
\hline Fase de Voo & $\begin{array}{c}\text { Altitude } \\
{[\mathrm{m}]}\end{array}$ & $\begin{array}{c}\mathbf{T}_{\mathbf{0}} \\
{[\mathbf{K}]}\end{array}$ & $\begin{array}{l}\mathbf{T}_{1 \mathrm{~V}} \\
{[\mathrm{~K}]}\end{array}$ & $\begin{array}{l}\mathbf{T}_{2 \mathrm{~V}} \\
{[\mathrm{~K}]}\end{array}$ & $\begin{array}{l}\mathbf{T}_{1 \mathrm{R}} \\
{[\mathrm{K}]}\end{array}$ & $\begin{array}{l}\mathbf{T}_{2 \mathrm{R}} \\
{[\mathrm{K}]}\end{array}$ & $\begin{array}{l}\mathbf{T}_{3 \mathrm{R}} \\
{[\mathrm{K}]}\end{array}$ & $\begin{array}{l}\mathbf{T}_{2 \mathrm{C}} \\
{[\mathrm{K}]}\end{array}$ & $\begin{array}{l}\mathbf{T}_{3 \mathrm{C}} \\
{[\mathbf{K}]}\end{array}$ & $\begin{array}{c}\mathbf{T}_{3} \\
{[\mathbf{K}]}\end{array}$ & $\begin{array}{c}\mathbf{T}_{4} \\
{[\mathbf{K}]}\end{array}$ & $\begin{array}{c}\mathbf{T}_{5} \\
{[\mathbf{K}]}\end{array}$ & $\begin{array}{r}\mathbf{T}_{5 \mathbf{i}} \\
{[\mathbf{K}]}\end{array}$ & $\begin{array}{c}\mathbf{T}_{6} \\
{[\mathbf{K}]}\end{array}$ & $\begin{array}{c}\mathbf{T}_{7} \\
{[\mathbf{K}]}\end{array}$ & $\begin{array}{r}\mathbf{T}_{7 \mathrm{i}} \\
{[\mathbf{K}]}\end{array}$ \\
\hline 1 - Decolagem & 0 & 288,2 & 335,4 & 488,2 & 290,2 & 376,9 & 423,4 & 607,5 & 493,0 & 493,0 & 400,1 & 507,0 & 487,8 & 330,9 & 226,0 & 193,9 \\
\hline 2 - Subida & 6096 & 248,5 & 309,7 & 446,3 & 262,9 & 338,4 & 400,3 & 571,5 & 493,0 & 493,0 & 369,3 & 451,7 & 436,9 & 333,6 & 217,9 & 193,2 \\
\hline 3 - Subida & 10668 & 218,8 & 286,5 & 391,5 & 235,8 & 306,4 & 381,0 & 538,2 & 493,0 & 493,0 & 343,7 & 412,3 & 400,0 & 300,7 & 202,2 & 181,6 \\
\hline 4 - Cruzeiro & 11277,6 & 216,7 & 288,5 & 394,2 & 239,5 & 310,0 & 383,2 & 538,3 & 493,0 & 493,0 & 346,6 & 415,8 & 403,4 & 271,1 & 205,3 & 184,5 \\
\hline 5 - Cruzeiro & 12496,8 & 216,7 & 287,7 & 390,1 & 239,5 & 310,0 & 383,2 & 536,0 & 493,0 & 493,0 & 346,6 & 415,8 & 403,4 & 274,8 & 205,3 & 184,5 \\
\hline 6 - Descida & 10668 & 218,8 & 264,9 & 287,3 & 241,9 & 315,1 & 386,2 & 496,0 & 493,0 & 493,0 & 350,6 & 424,8 & 411,4 & 274,8 & 204,0 & 181,8 \\
\hline 7 - Descida & 6096 & 248,5 & 281,1 & 343,3 & 265,5 & 345,5 & 404,5 & 507,1 & 493,0 & 493,0 & 375,0 & 465,3 & 449,1 & 278,5 & 214,6 & 187,5 \\
\hline 8 - Espera & 4572 & 258,4 & 305,3 & 494,3 & 265,8 & 342,4 & 402,6 & 633,0 & 493,0 & 493,0 & 372,5 & 457,3 & 442,0 & 305,5 & 218,9 & 193,4 \\
\hline 9 - Aproximação e aterrissagem & 0 & 288,2 & 297,6 & 297,6 & 290,2 & 374,7 & 416,8 & 480,0 & 480,0 & 480,0 & 395,8 & 501,5 & 482,4 & 304,1 & 226,1 & 194,3 \\
\hline
\end{tabular}


Tabela 8.10: Potência na turbina da UCA, eficiência e fluxo de calor do pré-resfriador e fluxos de calor do trocador primário e secundário da UCA - sistema de antigelo desligado.

\begin{tabular}{|c|c|c|c|c|c|c|}
\hline Fase de Voo & $\begin{array}{c}\text { Altitude } \\
{[\mathrm{m}]}\end{array}$ & $\begin{array}{c}\mathbf{W}_{\text {turb_UCA }} \\
{[\mathrm{kW}]}\end{array}$ & $\boldsymbol{\varepsilon}_{\mathrm{PR}}$ & $\begin{array}{c}\mathbf{Q}_{\mathbf{P R}} \\
{[\mathrm{kW}]}\end{array}$ & $\begin{array}{l}\mathbf{Q}_{\mathrm{TC1}} \\
{[\mathrm{kW}]}\end{array}$ & $\begin{array}{l}\mathbf{Q}_{\mathrm{TC2}} \\
{[\mathrm{kW}]}\end{array}$ \\
\hline 1 - Decolagem & 0 & 24,18 & 0,42 & 26,79 & 21,32 & 39,92 \\
\hline 2 - Subida & 6096 & 11,60 & 0,30 & 11,36 & 17,73 & 21,51 \\
\hline 3 - Subida & 10668 & 12,58 & 0,18 & 8,53 & 27,93 & 26,09 \\
\hline 4 - Cruzeiro & 11277,6 & 13,23 & 0,18 & 8,91 & 28,54 & 27,17 \\
\hline 5 - Cruzeiro & 12496,8 & 12,65 & 0,17 & 8,09 & 27,29 & 25,98 \\
\hline 6 - Descida & 10668 & 13,60 & 0,01 & 0,56 & 26,63 & 27,07 \\
\hline 7 - Descida & 6096 & 12,74 & 0,02 & 0,72 & 16,93 & 22,81 \\
\hline 8 - Espera & 4572 & 13,72 & 0,24 & 9,61 & 19,84 & 25,07 \\
\hline $\begin{array}{l}9 \text { - Aproximação e } \\
\text { aterrissagem }\end{array}$ & 0 & 23,52 & 0,00 & 0,00 & 16,50 & 37,39 \\
\hline
\end{tabular}

Tabela 8.11: Potência na turbina da UCA, fluxo de calor e eficiência do pré-resfriador e fluxos de calor do trocador primário e secundário da UCA - sistema de antigelo ligado.

\begin{tabular}{|c|c|c|c|c|c|c|}
\hline Fase de Voo & $\begin{array}{c}\text { Altitude } \\
{[\mathrm{m}]}\end{array}$ & $\begin{array}{c}\mathbf{W}_{\text {turb_UCA }} \\
{[\mathbf{k W}]} \\
\end{array}$ & $\boldsymbol{\varepsilon}_{\mathrm{PR}}$ & $\begin{array}{c}\mathbf{Q}_{\mathrm{PR}} \\
{[\mathrm{kW}]}\end{array}$ & $\begin{array}{r}\mathbf{Q}_{\mathrm{TC1}} \\
{[\mathrm{kW}]} \\
\end{array}$ & $\begin{array}{c}\mathbf{Q}_{\mathrm{TC2}} \\
{[\mathrm{kW}]} \\
\end{array}$ \\
\hline 1 - Decolagem & 0 & 24,18 & 0,42 & 88,41 & 21,32 & 39,92 \\
\hline 2 - Subida & 6096 & 11,60 & 0,30 & 53,27 & 17,73 & 21,51 \\
\hline 3 - Subida & 10668 & 12,58 & 0,18 & 8,53 & 27,93 & 26,09 \\
\hline 4 - Cruzeiro & 11277,6 & 13,23 & 0,18 & 8,91 & 28,54 & 27,17 \\
\hline 5 - Cruzeiro & 12496,8 & 12,65 & 0,17 & 8,09 & 27,29 & 25,98 \\
\hline 6 - Descida & 10668 & 13,60 & 0,01 & 0,56 & 26,63 & 27,07 \\
\hline 7 - Descida & 6096 & 12,74 & 0,06 & 9,44 & 16,93 & 22,81 \\
\hline 8 - Espera & 4572 & 13,72 & 0,43 & 99,37 & 19,84 & 25,07 \\
\hline $\begin{array}{l}9 \text { - Aproximação e } \\
\text { aterrissagem }\end{array}$ & 0 & 23,52 & 0,00 & 0,00 & 16,50 & 37,39 \\
\hline
\end{tabular}




\subsubsection{Sistema de proteção contra gelo}

O dimensionamento da vazão mássica de ar sangrado nos motores é geralmente feito para a pior condição de formação de gelo conforme mostrado na seção 8.1.2. Esta vazão depende da temperatura de saída do pré-resfriador, que foi considerada $220{ }^{\circ} \mathrm{C}$ na entrada dos sistemas de antigelo da asa e estabilizador, e $260{ }^{\circ} \mathrm{C}$ na entrada do sistema de antigelo dos motores. Isto se deve ao fato de que a vazão de ar que é direcionada para a asa e estabilizador passa pelo pré-resfriador e tem a sua temperatura regulada, conforme critério estabelecido na seção 8.2.2.1. A extração de ar comprimido para o sistema de antigelo do motor é feita no pórtico de maior pressão do sistema de extração pneumática, entretanto, essa vazão não tem sua temperatura regulada no pré-resfriador pois o encaminhamento é feito à montante do mesmo (vide Figura 8.10).

A Figura 8.11 mostra um esquema do sistema de proteção antigelo. A pressão do ar na entrada do sistema é regulada conforme projeto específico de cada aeronave, pois depende da pressão de extração do compressor do motor e da perda de carga de dutos e válvulas, incluindo o duto injetor que direciona o ar comprimido para a região interna das bordas de ataque por meio de pequenos canais.

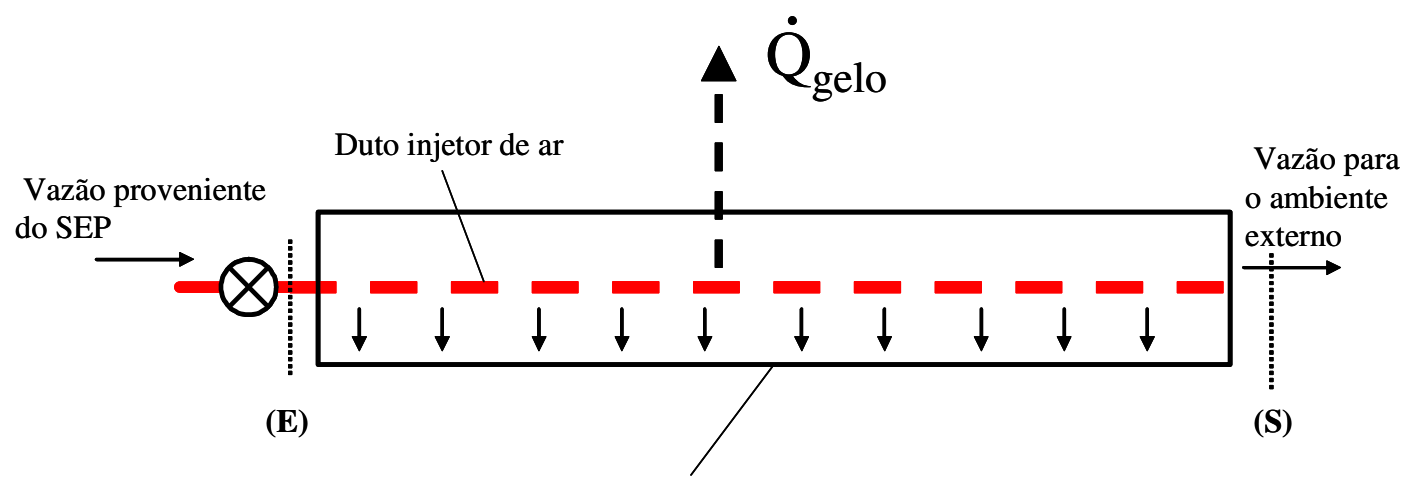

Borda de ataque

Figura 8.11: Esquema do sistema de proteção contra gelo para o avião com sistemas convencionais.

O cálculo da taxa de transferência de calor nas bordas de ataque $\left(\dot{Q}_{\text {gelo }}\right)$ para cada ponto do voo analisado foi confeccionado utilizando o rendimento da transferência de calor 
interna da borda de ataque estabelecido na seção 8.1.2.5. A Tabela 8.12 à Tabela 8.15 resumem os principais dados e resultados nos pontos do voo nos quais o sistema de proteção contra gelo permanece ligado.

Tabela 8.12: Vazões de ar estabelecidas para o sistema de antigelo (semi asa, semi empenagem e um motor).

\begin{tabular}{ccccc}
\hline Fase de Voo & $\begin{array}{c}\text { Altitude } \\
{[\mathbf{m}]}\end{array}$ & $\begin{array}{c}\text { Vazão } \\
{[\mathbf{k g} / \mathbf{s}]}\end{array}$ & $\begin{array}{c}\text { Vazão } \\
{[\mathbf{k g} / \mathbf{s}]}\end{array}$ & $\begin{array}{c}\text { Vazãagem }_{\text {entrada motor }} \\
{[\mathbf{k g} / \mathbf{s}]}\end{array}$ \\
\hline 1- Decolagem & 0 & 0,322 & 0,095 & 0,093 \\
2 - Subida & 6096 & 0,322 & 0,095 & 0,093 \\
7 - Descida & 6096 & 0,322 & 0,095 & 0,093 \\
8 - Espera & 4572 & 0,322 & 0,095 & 0,093 \\
9 - Aproximação e & 0 & 0,322 & 0,095 & 0,093 \\
aterrissagem & 0 & & \\
\hline
\end{tabular}

Tabela 8.13: Pressões e temperaturas para o sistema de antigelo da asa e empenagem.

\begin{tabular}{ccccccccc}
\hline Fase de Voo & Altitude [m] & $\begin{array}{c}\mathbf{p}_{\mathbf{a}} \\
{[\mathbf{b a r}]}\end{array}$ & $\begin{array}{c}\mathbf{T}_{\mathbf{a}} \\
{[\mathbf{K}]}\end{array}$ & $\begin{array}{c}\mathbf{T}_{\mathbf{a w}} \\
{[\mathbf{K}]}\end{array}$ & $\begin{array}{c}\mathbf{p}_{\mathbf{e}} \\
{[\mathbf{b a r}]}\end{array}$ & $\begin{array}{c}\mathbf{T}_{\mathbf{e}} \\
{[\mathbf{K}]}\end{array}$ & $\begin{array}{c}\mathbf{p}_{\mathbf{s}} \\
{[\mathbf{b a r}]}\end{array}$ & $\begin{array}{c}\mathbf{T}_{\mathbf{s}} \\
{[\mathbf{K}]}\end{array}$ \\
\hline 1- Decolagem & 0 & 1,01 & 288,2 & 290,2 & 2,25 & 493,0 & 1,01 & 383,6 \\
2 - Subida & 6096 & 0,47 & 248,5 & 262,9 & 1,71 & 493,0 & 0,47 & 368,8 \\
7 - Descida & 6096 & 0,47 & 248,5 & 265,6 & 1,71 & 493,0 & 0,47 & 370,3 \\
8 - Espera & 4572 & 0,57 & 258,4 & 265,8 & 1,81 & 493,0 & 0,57 & 370,4 \\
9 - Aproximação & 0 & 1,01 & 288,2 & 290,2 & 2,25 & 493,0 & 1,01 & 383,6 \\
aterrissagem & 0 & & & & & & &
\end{tabular}

Tabela 8.14: Pressões e temperaturas para o sistema de antigelo do motor.

\begin{tabular}{ccccccccc}
\hline Fase de Voo & Altitude [m] & $\begin{array}{c}\mathbf{p}_{\mathbf{a}} \\
{[\mathbf{b a r}]}\end{array}$ & $\begin{array}{c}\mathbf{T}_{\mathbf{a}} \\
{[\mathbf{K}]}\end{array}$ & $\begin{array}{c}\mathbf{T}_{\mathbf{a w}} \\
{[\mathbf{K}]}\end{array}$ & $\begin{array}{c}\mathbf{p}_{\mathbf{e}} \\
{[\mathbf{b a r}]}\end{array}$ & $\begin{array}{c}\mathbf{T}_{\mathbf{e}} \\
{[\mathbf{K}]}\end{array}$ & $\begin{array}{c}\mathbf{p}_{\mathbf{s}} \\
{[\mathbf{b a r}]}\end{array}$ & $\begin{array}{c}\mathbf{T}_{\mathbf{s}} \\
{[\mathbf{K}]}\end{array}$ \\
\hline 1- Decolagem & 0 & 1,01 & 288,2 & 290,2 & 2,25 & 533,0 & 1,01 & 401,9 \\
2 - Subida & 6096 & 0,47 & 248,5 & 262,9 & 1,71 & 533,0 & 0,47 & 387,2 \\
7 - Descida & 6096 & 0,47 & 248,5 & 265,6 & 1,71 & 533,0 & 0,47 & 388,6 \\
8 - Espera & 4572 & 0,57 & 258,4 & 265,8 & 1,81 & 533,0 & 0,57 & 388,7 \\
9 - Aproximação & 0 & 1,01 & 288,2 & 290,2 & 2,25 & 533,0 & 1,01 & 401,9 \\
aterrissagem & 0 & & & & & & &
\end{tabular}

Tabela 8.15: Taxas de transferência de calor do sistema de antigelo (semi asa, semi empenagem e um motor).

\begin{tabular}{ccccc}
\hline Fase de Voo & $\begin{array}{c}\text { Altitude } \\
{[\mathbf{m}]}\end{array}$ & $\begin{array}{c}\mathbf{Q}_{\text {gelo_asa }} \\
{[\mathbf{k W}]}\end{array}$ & $\begin{array}{c}\mathbf{Q}_{\text {gelo_estabilizador }} \\
{[\mathbf{k W}]}\end{array}$ & $\begin{array}{c}\mathbf{Q}_{\text {gelo_motor }} \\
{[\mathbf{k W}]}\end{array}$ \\
\hline 1- Decolagem & 0 & 35,24 & 10,40 & 12,19 \\
2 - Subida & 6096 & 39,98 & 11,80 & 13,56 \\
7 - Descida & 6096 & 39,52 & 11,66 & 13,43 \\
8 - Espera & 4572 & 39,48 & 11,65 & 13,42 \\
9 - Aproximação e & 0 & 35,24 & 10,40 & 12,19 \\
aterrissagem & 0 & & & 19 \\
\hline
\end{tabular}




\subsection{Sistemas mais elétricos}

Assim como a seção 8.2 abordou a modelagem envolvida para os sistemas convencionais, descreve-se nesta seção as considerações e abordagens envolvidas na modelagem dos sistemas mais elétricos.

\subsubsection{Motor}

O modelo do motor também foi confeccionado com o auxílio do simulador GSP. A modelagem do motor para a abordagem mais elétrica seguiu as mesmas fases conceituais (como esquematizado na Figura 8.8), entretanto com a diferença que se altera a extração de ar do compressor e se elimina a extração de ar do ventilador. No modelo desse motor (Figura 8.12), continua-se usando ar do compressor para realizar o antigelo da entrada de ar do motor conforme explicações dadas na seção 8.3.3.

Os mesmos componentes como coletor dinâmico, ventilador, dutos, compressor, câmara de combustão, turbinas, misturador, eixos, com os mesmos dados construtivos (diâmetro de bocais, taxa de derivação, eficiências e mapas de componentes, etc.) foram utilizados na construção do modelo do motor mais elétrico.

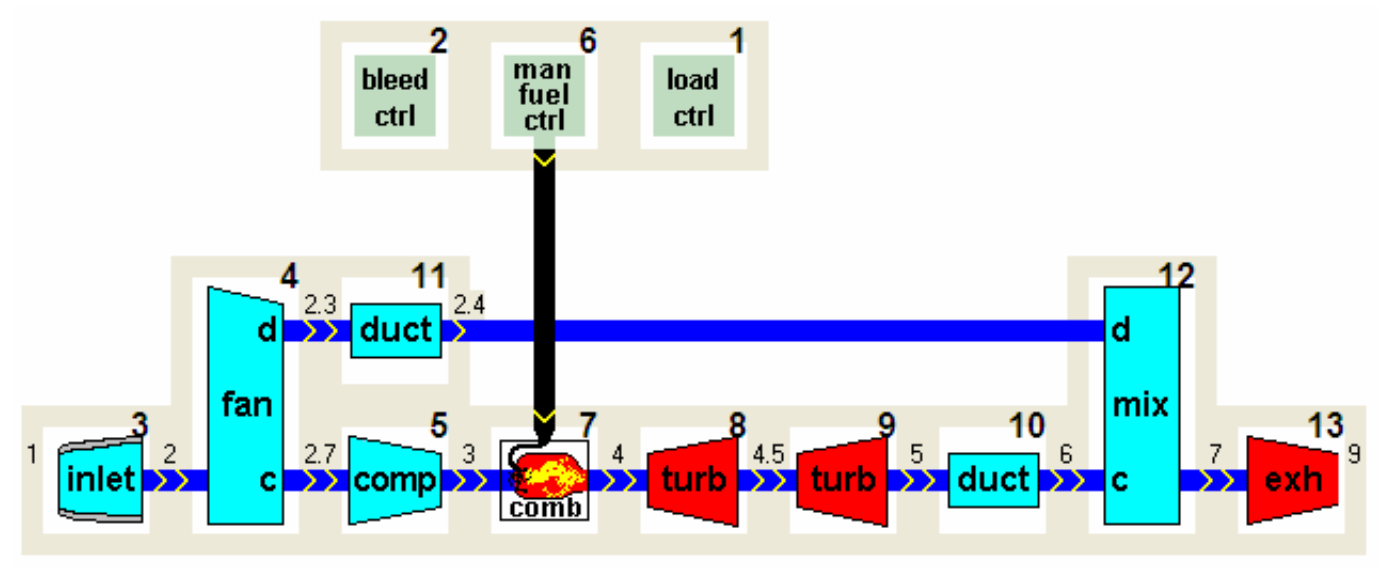

Figura 8.12: Modelo completo do motor para o avião com sistemas mais elétricos.

Nesse modelo não são inseridos controles das forças aplicadas aos eixos, mas é inserido o controle manual de injeção de combustível, semelhante ao motor para a abordagem 
convencional, permitindo definir o fluxo na entrada da câmara de combustão nas condições fora do ponto de projeto.

O modelo simula extrações no compressor e no eixo de menor rotação nas diferentes fases de voo, por este motivo são incluídos controle de sangria ("bleed control") e controle de extração de potência de eixo. A mesma condição de extração de ar do motor para a abordagem convencional é utilizada quando o antigelo do motor está ligado:

- antigelo ligado : extração no $14^{\circ}$ estágio do compressor, quando o motor está em regime de baixa tração; extração no $9^{\circ}$ estágio do compressor, quando o motor está em regime de alta tração (utlizando o fator FracH para estabelecimento da fração de entalpia fornecido pelo compressor).

O controle de extração de potência de eixo define a potência necessária para a alimentação da bomba hidráulica e do gerador elétrico, que nesse caso aumenta consideravelmente. Todas as extrações de potência de eixo foram contabilizadas em apenas um controle de extração.

\subsubsection{Definição do ponto de projeto}

O cálculo do ponto de projeto seguiu os mesmos passos que o modelo para a abordagem convencional, entretanto, utilizou-se o mesmo requisito de tração. Esta abordagem é simplificadora pois no avião com sistemas mais elétricos tem-se, além da variação de extração de potência, uma variação dos requisitos de tração do avião pois se modificam o peso e o arrasto da aeronave devido à instalação dos sistemas mais elétricos. $\mathrm{O}$ arrasto é modificado pois o compressor de cabine exige a instalação de novas tomadas de ar que aumentam o arrasto dessa aeronave. Este assunto será abordado com mais detalhes na seção 10. Os principais detalhes do ponto de projeto são:

- Condição de voo cruzeiro com antigelo desligado;

- Altitude: $11277 \mathrm{~m}$;

- Mach: 0,77;

- Empuxo: $9000 \mathrm{~N}$;

- Vazão de ar extraída do ventilador: 0 kg/s;

- Vazão de ar extraída do compressor: 0 kg/s; 
- Potência extraída do eixo de menor rotação: $62,12 \mathrm{~kW}$ (15 kW referentes a extrações convencionais e 47,12 kW referentes ao compressor de cabine);

- Rotação do compressor: 14600 rpm;

- Rotação do ventilador: 8000 rpm;

- Temperatura dos gases entre as turbinas de alta e de baixa pressão: 1012,6 K;

- Consumo de combustível: $0,1680 \mathrm{~kg} / \mathrm{s}$.

\subsubsection{Sistema de controle ambiental}

A aeronave mais elétrica não possui o SEP que controla pressão e temperatura do ar extraído do compressor do motor. Todavia, a arquitetura do sistema de controle ambiental para o avião mais elétrico abordado neste trabalho envolve a substituição da fonte pneumática por compressores de cabine (vide Figura 8.13), que comprimem o ar externo proveniente de uma tomada de ar de alta eficiência cujo fator de recuperação de pressão $\mathrm{R}$ foi considerado constante e igual a 0,90 para todos os pontos de operação. A temperatura e a pressão do ar direcionado ao compressor de cabine e aos trocadores de calor da UCA (estado 1R) são dadas por:

$$
\begin{gathered}
T_{1 R}=T_{0}\left(1+R\left(\frac{\gamma-1}{2} M^{2} a c h^{2}\right)\right) \\
p_{1 R}=p_{0}\left(1+R\left(\frac{\gamma-1}{2} M^{2} a c h^{2}\right)\right)^{\left(\frac{\gamma}{\gamma-1}\right)}
\end{gathered}
$$

Utilizou-se a hipótese que a UCA do avião mais elétrico é a mesma que a do avião convencional. Isto significa que as mesmas hipóteses e abordagens utilizadas na modelagem da UCA do avião convencional foram assumidas (mesma modelagem e eficiências). Assim sendo, a pressão do ar na saída do compressor de cabine foi assumida igual à pressão na entrada da UCA $\left(\mathrm{P}_{1 \mathrm{CE}}=\mathrm{P}_{3}\right)$. Esta hipótese é baseada no fato de o motor elétrico, que aciona o compressor de cabine, pode ter a sua rotação controlada por fase de voo (ou altitude) e assim obter pressões próximas às pressões requeridas na entrada da UCA. 
Para o compressor de cabine, considerou-se compressão isentrópica com eficiência constante de 0,75 , em todas as fases de voo. Conhecido o estado $1 \mathrm{R}$, a eficiência isentrópica do compressor ( $\eta_{\text {comp_cabine }}$ ) e a pressão do estado 1CE, o estado de saída 1CE pode ser obtido por:

$$
\eta_{\text {comp_cabine }}=\frac{H_{1 C E i}-H_{1 R}}{H_{1 C E}-H_{1 R}}
$$

Assumindo que a vazão de ar direcionada à UCA é a mesma usada para a configuração convencional ( $\left.\dot{m}_{a r_{-} U C A}\right)$, a potência de compressão pode ser obtida por:

$$
\dot{W}_{\text {comp_cabine }}=\dot{m}_{a r_{-} U C A}\left(H_{1 C E}-H_{1 R}\right)
$$

Para o cálculo da potência elétrica demandada ao gerador elétrico, assumiu-se eficiência de transmissão mecânica $\left(\eta_{\text {transmissão }}\right)$ entre compressor e motor elétrico de 0,97 e eficiência do motor elétrico $\left(\eta_{\text {motor_elétrico }}\right)$ de 0,85 , constantes em todas as fases de voo.

$$
\begin{gathered}
\eta_{\text {transmissão }}=\frac{\dot{W}_{\text {comp_cabine }}}{\dot{W}_{\text {eixo }}} \\
\dot{W}_{\text {demanda }}=\frac{\dot{W}_{\text {eixo }}}{\eta_{\text {motor_elétrico }}}
\end{gathered}
$$




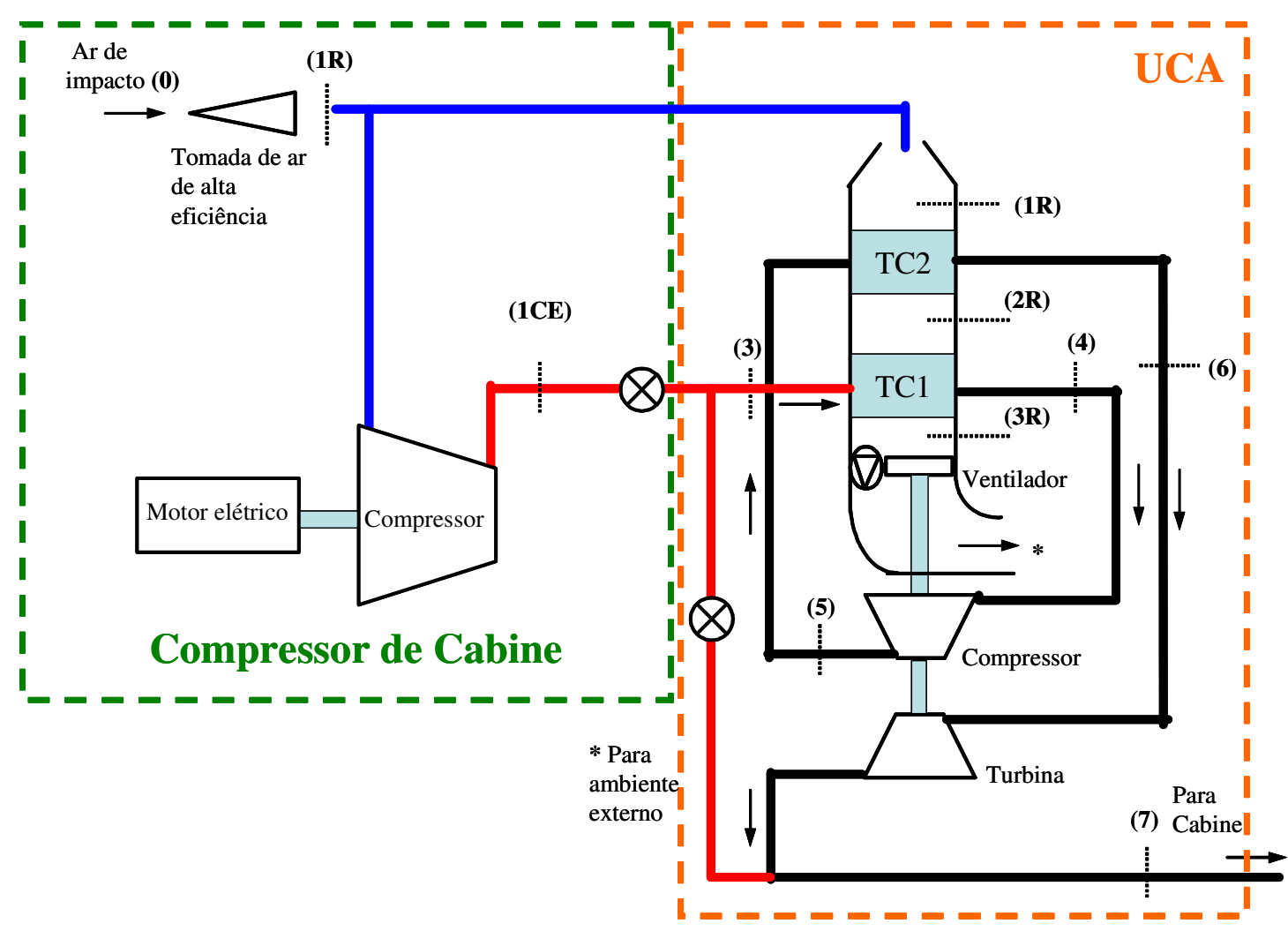

Figura 8.13: Esquema do sistema de controle ambiental para o avião com sistemas mais elétricos (compressor de cabine + UCA).

Os principais resultados para o sistema mais elétrico de controle ambiental são observados na Tabela 8.16 à Tabela 8.18 . 
Tabela 8.16: Vazões mássicas e pressões do sistema de controle ambiental mais elétrico.

\begin{tabular}{|c|c|c|c|c|c|c|c|c|c|}
\hline Fase de Voo & Altitude [m] & $\begin{array}{c}\mathbf{m}_{\text {ar_UCA }} \\
{[\mathrm{kg} / \mathrm{s}]} \\
\end{array}$ & $\begin{array}{c}\mathbf{m}_{\mathrm{ar} \_ \text {impacto }} \\
{[\mathrm{kg} / \mathrm{s}]}\end{array}$ & $\begin{array}{c}\mathbf{p}_{0} \\
\text { [bar] }\end{array}$ & $\begin{array}{c}\mathbf{p}_{1 \mathrm{R}} \\
{[\mathrm{bar}]}\end{array}$ & $\begin{array}{c}\mathbf{p}_{1 \mathrm{CE}} \\
{[\mathrm{bar}]}\end{array}$ & $\begin{array}{l}\mathbf{p}_{3}=\mathbf{p}_{4} \\
{[\mathrm{bar}]}\end{array}$ & $\begin{array}{l}p_{5}=p_{6} \\
{[\text { bar }]}\end{array}$ & $\begin{array}{c}\mathbf{p}_{7} \\
{[\mathrm{bar}]}\end{array}$ \\
\hline 1 - Decolagem & 0 & 0,223 & 0,447 & 1,01 & 1,04 & 3,12 & 3,12 & 6,23 & 1,04 \\
\hline 2 - Subida & 6096 & 0,140 & 0,279 & 0,47 & 0,57 & 2,17 & 2,17 & 3,90 & 0,91 \\
\hline 3 - Subida & 10668 & 0,182 & 0,364 & 0,24 & 0,31 & 1,77 & 1,77 & 3,01 & 0,80 \\
\hline 4 - Cruzeiro & 11277,6 & 0,190 & 0,379 & 0,22 & 0,31 & 1,73 & 1,73 & 2,95 & 0,78 \\
\hline 5 - Cruzeiro & 12496,8 & 0,181 & 0,363 & 0,18 & 0,25 & 1,67 & 1,67 & 2,84 & 0,73 \\
\hline 6 - Descida & 10668 & 0,182 & 0,364 & 0,24 & 0,34 & 1,77 & 1,77 & 3,10 & 0,75 \\
\hline 7 - Descida & 6096 & 0,140 & 0,279 & 0,47 & 0,59 & 2,17 & 2,17 & 4,07 & 0,82 \\
\hline 8 - Espera & 4572 & 0,160 & 0,320 & 0,57 & 0,63 & 2,35 & 2,35 & 4,28 & 0,96 \\
\hline 9 - Aproximação e aterrissagem & 0 & 0,223 & 0,447 & 1,01 & 1,04 & 3,12 & 3,12 & 6,23 & 1,04 \\
\hline
\end{tabular}

Tabela 8.17: Temperaturas do sistema de controle ambiental mais elétrico.

\begin{tabular}{|c|c|c|c|c|c|c|c|c|c|c|c|c|c|}
\hline Fase de Voo & $\begin{array}{c}\text { Altitude } \\
{[\mathrm{m}]}\end{array}$ & $\begin{array}{c}\mathbf{T}_{\mathbf{0}} \\
{[\mathbf{K}]}\end{array}$ & $\begin{array}{l}\mathbf{T}_{1 \mathrm{R}} \\
{[\mathrm{K}]}\end{array}$ & $\begin{array}{l}\mathbf{T}_{2 \mathbf{R}} \\
{[\mathbf{K}]}\end{array}$ & $\begin{array}{l}\mathbf{T}_{3 \mathbf{R}} \\
{[\mathbf{K}]}\end{array}$ & $\begin{array}{l}\mathbf{T}_{1 \mathrm{CE}} \\
{[\mathbf{K}]}\end{array}$ & $\begin{array}{c}\mathbf{T}_{3} \\
{[\mathbf{K}]}\end{array}$ & $\begin{array}{c}\mathbf{T}_{4} \\
{[\mathbf{K}]}\end{array}$ & $\begin{array}{c}\mathbf{T}_{\mathbf{5}} \\
{[\mathbf{K}]}\end{array}$ & $\begin{array}{r}\mathbf{T}_{5 \mathbf{i}} \\
{[\mathbf{K}]}\end{array}$ & $\begin{array}{c}\mathbf{T}_{6} \\
{[\mathbf{K}]}\end{array}$ & $\begin{array}{c}\mathbf{T}_{7} \\
{[\mathbf{K}]}\end{array}$ & $\begin{array}{c}\mathbf{T}_{7 \mathbf{i}} \\
{[\mathbf{K}]}\end{array}$ \\
\hline 1 - Decolagem & 0 & 288,2 & 290,2 & 366,6 & 392,8 & 432,2 & 432,2 & 379,7 & 481,1 & 462,8 & 328,4 & 227,1 & 196,8 \\
\hline 2 - Subida & 6096 & 248,5 & 262,9 & 327,6 & 366,9 & 425,9 & 425,9 & 347,3 & 424,7 & 410,8 & 295,3 & 217,9 & 194,8 \\
\hline 3 - Subida & 10668 & 218,8 & 235,8 & 297,9 & 354,0 & 438,2 & 438,2 & 325,9 & 391,0 & 379,3 & 266,8 & 201,8 & 182,4 \\
\hline 4 - Cruzeiro & 11277,6 & 216,7 & 239,5 & 302,2 & 358,4 & 442,8 & 442,8 & 330,3 & 396,3 & 384,4 & 270,9 & 205,0 & 185,3 \\
\hline 5 - Cruzeiro & 12496,8 & 216,7 & 239,5 & 305,8 & 369,8 & 465,8 & 465,8 & 337,8 & 405,3 & 393,1 & 272,7 & 205,2 & 185,1 \\
\hline 6 - Descida & 10668 & 218,8 & 241,9 & 306,1 & 358,1 & 436,2 & 436,2 & 332,1 & 402,3 & 389,7 & 274,0 & 203,8 & 182,9 \\
\hline 7 - Descida & 6096 & 248,5 & 265,5 & 334,3 & 370,6 & 425,0 & 425,0 & 352,4 & 437,4 & 422,1 & 299,9 & 215,0 & 189,7 \\
\hline 8 - Espera & 4572 & 258,4 & 265,8 & 331,7 & 369,7 & 426,8 & 426,8 & 350,7 & 430,5 & 416,2 & 298,7 & 219,0 & 195,2 \\
\hline 9 - Aproximação e aterrissagem & 0 & 288,2 & 290,2 & 366,6 & 392,8 & 432,2 & 432,2 & 379,7 & 481,1 & 462,8 & 328,4 & 227,1 & 196,8 \\
\hline
\end{tabular}


Tabela 8.18: Potência do compressor de cabine, potência demandada ao gerador, potência na turbina da UCA e fluxos de calor do trocador primário e secundário da UCA do sistema de controle ambiental mais elétrico.

\begin{tabular}{|c|c|c|c|c|c|c|}
\hline Fase de Voo & $\begin{array}{c}\text { Altitude } \\
{[\mathrm{m}]}\end{array}$ & $\begin{array}{c}\mathbf{W}_{\text {comp_cabine }} \\
{[\mathrm{kW}]}\end{array}$ & $\begin{array}{c}\mathbf{W}_{\text {demanda }} \\
{[\mathbf{k W}]}\end{array}$ & $\begin{array}{c}\mathbf{W}_{\text {turb_UCA }} \\
{[\mathrm{kW}]}\end{array}$ & $\begin{array}{l}\mathbf{Q}_{\mathrm{TC1}} \\
{[\mathrm{kW}]} \\
\end{array}$ & $\begin{array}{l}\mathbf{Q}_{\mathrm{TC} 2} \\
{[\mathrm{~kW}]}\end{array}$ \\
\hline 1 - Decolagem & 0 & 32,01 & 38,89 & 22,96 & 11,95 & 35,10 \\
\hline 2 - Subida & 6096 & 22,93 & 27,81 & 10,92 & 11,17 & 18,42 \\
\hline 3 - Subida & 10668 & 37,15 & 45,01 & 11,95 & 20,84 & 22,94 \\
\hline 4 - Cruzeiro & 11277,6 & 38,89 & 47,12 & 12,62 & 21,77 & 24,16 \\
\hline 5 - Cruzeiro & 12496,8 & 41,47 & 50,24 & 12,35 & 23,79 & 24,45 \\
\hline 6 - Descida & 10668 & 35,65 & 43,21 & 12,90 & 19,32 & 23,74 \\
\hline 7 - Descida & 6096 & 22,44 & 27,22 & 11,98 & 10,31 & 19,59 \\
\hline 8 - Espera & 4572 & 26,02 & 31,57 & 12,93 & 12,42 & 21,55 \\
\hline $\begin{array}{c}9 \text { - Aproximação e } \\
\text { aterrissagem }\end{array}$ & 0 & 32,01 & 38,89 & 22,96 & 11,95 & 35,10 \\
\hline
\end{tabular}




\subsubsection{Sistema de proteção contra gelo}

O sistema de proteção contra gelo mais elétrico adotado neste trabalho é o sistema de proteção cíclico eletro-térmico, conforme explicado na seção 1.2.3.1. A potência consumida por este sistema pode variar consideravelmente dependendo da estratégia e necessidade de proteção envolvida. Quanto maior a envergadura da asa e espessura, menor a penalidade imposta ao avião pela formação de gelo, entretanto, quanto menor a asa, maior é a penalidade imposta ao avião pelo gelo formado. Como resultado, o sistema de proteção eletro-térmico deve ser ajustado para cada caso, analisando a quantidade de mantas a serem instaladas, localização das mesmas, potência elétrica consumida individualmente por cada uma delas, tempo de aquecimento, etc.

Elangovan e Olsen (2008) apresentaram uma análise numérica da aplicação de um sistema de proteção eletro-térmico para a entrada de ar do motor. Como resultados, os requisitos de potência médios nas regiões protegidas variam de 3,1 a 7,8 kW/m², valores relativamente menores do que os obtidos para a proteção que utiliza ar quente (Tabela 8.5). Assim sendo, considerou-se neste trabalho o valor de $7,8 \mathrm{~kW} / \mathrm{m}^{2}$ como requisito de potência para as regiões protegidas da asa e empenagem horizontal que utilizam o sistema eletrotérmico. As potências totais médias consumidas pela semi asa e semi empenagem para o avião em estudo são, respectivamente, $15,1 \mathrm{~kW}$ e $6,2 \mathrm{~kW}$.

Por outro lado, manteve-se a proteção térmica com ar quente sangrado do compressor do motor para a entrada de ar do mesmo. Como critérios, a potência consumida na entrada do motor é menor do que a consumida nas superfícies de sustentação e os dutos de antigelo do motor são instalados na zona de proteção contra fogo do motor, caso ocorra algum vazamento não detectado, este é menos crítico do que vazamentos na borda de ataque da asa pois esta é feita de alumínio e a região é muito próxima ao tanque de combustível. Além disso, há uma relativa facilidade de utilizar ar do compressor do motor devido à proximidade da região a ser protegida, menor complexidade do sistema a ar quente (menos componentes) e a região de instalação do duto no motor é certificada para suportar vazamentos de ar comprimido. 


\section{Análise Exergética Comparativa Entre Avião Com Sistemas Convencionais e Avião Com Sistemas Mais Elétricos}

A determinação dos fluxos de exergia para cada fase da missão foi efetuada empregando-se as seguintes hipóteses:

- Em cada fase do voo foi considerada operação em regime permanente;

- Os fluxos de gases foram tratados como misturas ideais de gases perfeitos e suas propriedades determinadas com o programa EES - "Engineering Equation Solver" (KLEIN, 2007);

- A exergia do calor transferido pelo fluxo de ar usado no sistema de antigelo foi considerado como o efeito útil desse sistema;

- As demandas de potência elétrica e hidráulica foram estimadas a partir de dados operacionais de uma aeronave comercial;

- O estado de referência para cálculo dos fluxos e taxas de exergia foi fixado para cada pressão e temperatura de estagnação do ar externo em cada fase do voo, assim como a composição química do estado de referência;

- O modelo para realização da análise exergética foi implementado no programa EES;

- Utilizaram-se os mesmos requisitos de tração do avião com sistemas convencionais para o avião com sistemas mais elétricos. Isto significa que as duas versões possuem o mesmo modelo de mecânica de voo. A análise de sensibilidade desses requisitos foi feita em capítulo dedicado.

Considerou-se que o balanço de forças para o avião ocorre conforme considerações apresentadas no Capítulo 7. Para fins da realização da análise exergética, é necessário avaliar a mecânica do voo associada com o simulador do motor para calcular os valores de tração, velocidade do avião e o consumo de combustível. Como parte dessa avaliação, a variação do peso do avião ao longo do vôo devido ao consumo de combustível é refletida nos requisitos de tração.

Os requisitos de tração por motor do avião com sistemas convencionais para cumprir a missão especificada são encontrados na Figura 9.1. Na seção 10 é analisada a influência da variação dos requisitos de tração devido à variação do peso e arrasto da aeronave com 
sistemas mais elétricos e, conseqüentemente, na análise exergética. Sendo assim, os requisitos de tração são re-avaliados naquela seção.

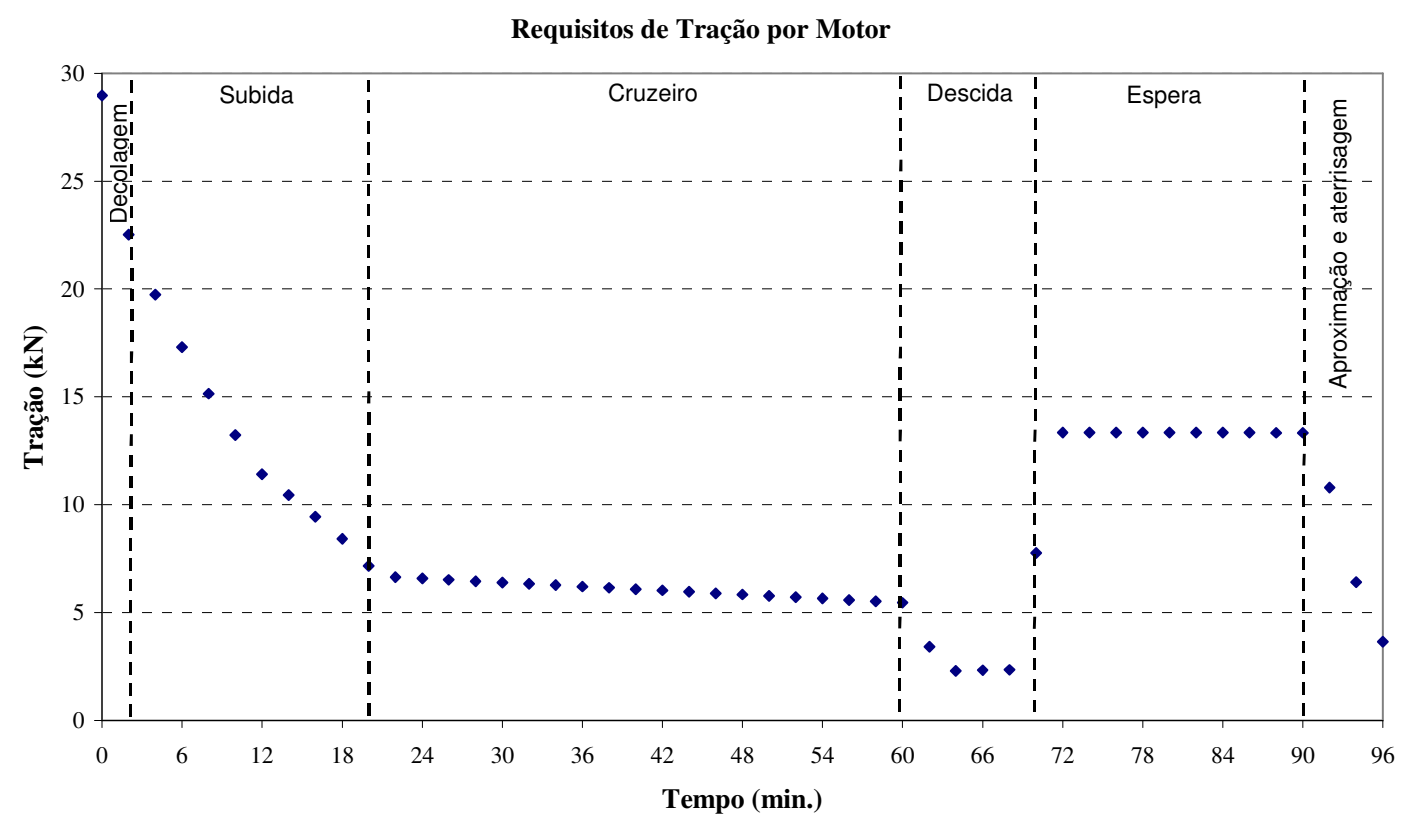

Figura 9.1: Requisitos de tração por motor.

O estudo também levou em conta condições em que o sistema de proteção contra gelo está em operação, porém, apenas em fases de voo nas quais a formação de gelo é suscetível de ocorrer: de 0 a 9000 metros de altitude.

\subsection{Considerações no cálculo da exergia}

Conforme indicado na seção 5.7, a exergia total de um sistema pode ser dividida em quatro componentes: exergia física, cinética, potencial e química. Aquela mesma seção aborda o equacionamento para um fluxo de uma mistura composta, mais adequada para a análise de sistemas aeronáuticos.

A análise exergética para sistemas aeronáuticos não deve levar em conta a parcela potencial da exergia porque o ambiente de referência usado nos cálculos acompanha a 
aeronave ao longo do voo. Um fluxo exergético potencial só faria sentido caso o ambiente de referência fosse fixo no solo.

A parcela cinética da exergia deve ser contabilizada para a vazão de ar na entrada do motor e para as vazões nas tomadas de ar dos trocadores de calor das UCA e dos compressores de cabine, nesse caso para o avião com sistemas mais elétricos. A parcela cinética é representativa para as vazões acima citadas visto que está relacionada com a velocidade absoluta do avião. As parcelas cinéticas dos outros fluxos de ar (extrações do motor, UCA, antigelo e cabine) podem ser desconsideradas.

A exergia química deve ser contabilizada para o combustível aeronáutico e para as vazões de ar dos sistemas. A constituição química do ambiente de referência é formada pelos gases presentes em abundância na atmosfera: $\mathrm{CO}_{2}, \mathrm{O}_{2}, \mathrm{~N}_{2}$ e Ar. Teoricamente, o valor da exergia química para as vazões de ar é zero. Entretanto, a fim de contabilizar pequenas variações da constituição química do modelo de atmosfera proveniente do simulador do motor com relação à referência adotada (KOTAS, 1985) para os valores de exergias químicas, calculou-se a parcela química da exergia das vazões de ar. A constituição química do modelo de atmosfera proveniente do simulador do motor é: $23,14 \%$ de $\mathrm{O}_{2}, 75,52 \%$ de $\mathrm{N}_{2}, 1,29 \%$ de Ar e $0,048 \%$ de $\mathrm{CO}_{2}$.

A exergia química do combustível aeronáutico foi considerada constante e igual a $45673 \mathrm{~kJ} / \mathrm{kg}$ (SZARGUT et al, 1988) em todas as condições de voo, mesmo com a mudança do ambiente de referência. Etele (2001) mostrou que a variação da exergia química do combustível para um ambiente de referência fixo em solo e um ambiente de referência fixo a 15000 metros é de apenas $0,6 \%$.

A parcela física da exergia deve ser contabilizada para todas as vazões de ar e pode ser desconsiderada para a vazão de combustível, devido à diferença na ordem de grandeza entre a parcela física e a parcela química para o mesmo.

Obs.: o Apêndice D apresenta resultados utilizando a abordagem de referencial fixo no solo para o avião com sistemas convencionais. Nesse caso, a parcela potencial é contabilizada para todos os fluxos envolvidos devido ao movimento do avião em relação ao ambiente de referência. A parcela cinética não é contabilizada apenas para os fluxos de entrada de ar no 
motor $\left(\dot{B}_{A r}\right)$ e entrada de ar no trocador de calor da UCA $\left(\dot{B}_{T C, e}\right)$, pois tais fluxos não se movem em relação ao ambiente de referência.

\subsection{Resultados do balanço exergético entre sistemas}

O método proposto no Capítulo 6 foi aplicado, o qual aborda os índices exergéticos de desempenho para os principais sistemas da aeronave convencional e na sua versão mais elétrica, como descritos nas seções 6.1 e 6.2, respectivamente. Calcularam-se as taxas de destruição de exergia dos sistemas para cada fase de voo analisada, a destruição de exergia total do avião na missão e a distribuição da destruição de exergia entre as fases de voo. As eficiências exergéticas de cada sistema também foram avaliadas em cada fase de voo e a eficiência exergética do avião para toda a missão. Com isso, tem-se a real figura de irreversibilidades e eficiências de cada sistema por fase de voo e do avião na missão como um todo. Por fim, o CEE foi calculado para cada sistema e para a estrutura, indicando a relação entre taxa de exergia consumida por cada sistema (ou estrutura) e taxa de exergia do combustível.

\subsubsection{Irreversibilidades}

A Figura 9.2 e a Figura 9.3 e mostram a distribuição das irreversibilidades entre os sistemas do avião com sistemas convencionais para duas fases do voo, cruzeiro (ponto de projeto do motor) e espera com o sistema de proteção contra gelo ligado, respectivamente. A exergia destruída no motor é a maior parcela, representando $96 \%$ do total da exergia destruída em espera e $98 \%$ em cruzeiro. Isto se deve ao fato que o motor possui processos altamente irreversíveis como a combustão (TONA et al., 2010), a mistura dos gases do fluxo interno com o ar do fluxo externo (derivação) e pela exergia física associada aos gases de escape, que é considerada exergia destruída. 


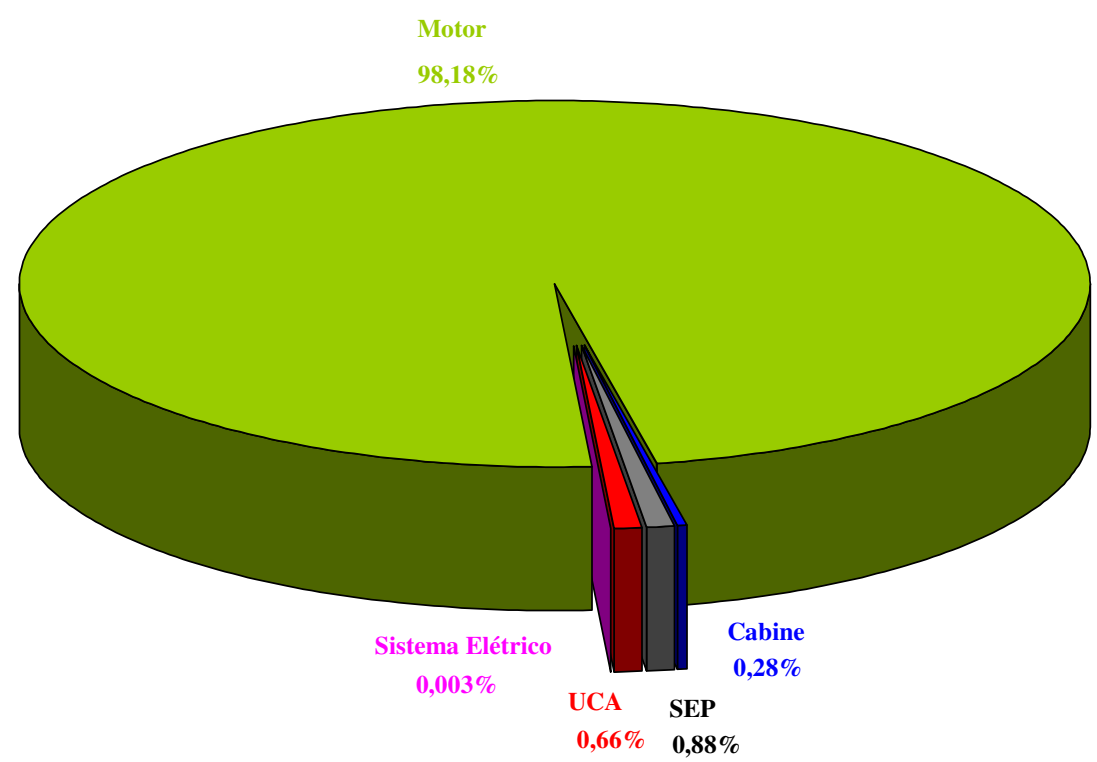

Figura 9.2: Distribuição das irreversibilidades do avião com sistemas convencionais durante a fase de cruzeiro a $11277 \mathrm{~m}$, com sistema de antigelo desligado.

O sistema de extração pneumática é o próximo sistema que apresenta maiores taxas de irreversibilidades, entretanto, muito menores que o motor. O sistema de extração pneumática é responsável por $0,9 \%$ da exergia destruída durante o cruzeiro e 3,0\% durante a fase de espera. Isto mostra que o aumento de irreversibilidades desse sistema é caracterizado pelo funcionamento do sistema de antigelo. O sistema de extração pneumática possui processos que são fontes de destruição de exergia como o controle de pressão em válvulas reguladoras e a troca térmica para realizar o controle de temperatura no pré-resfriador. Tais processos são necessários para atender aos requisitos dos sistemas clientes (UCA e antigelo). Os demais sistemas são responsáveis por menos de $1 \%$ do total de irreversibilidades. 


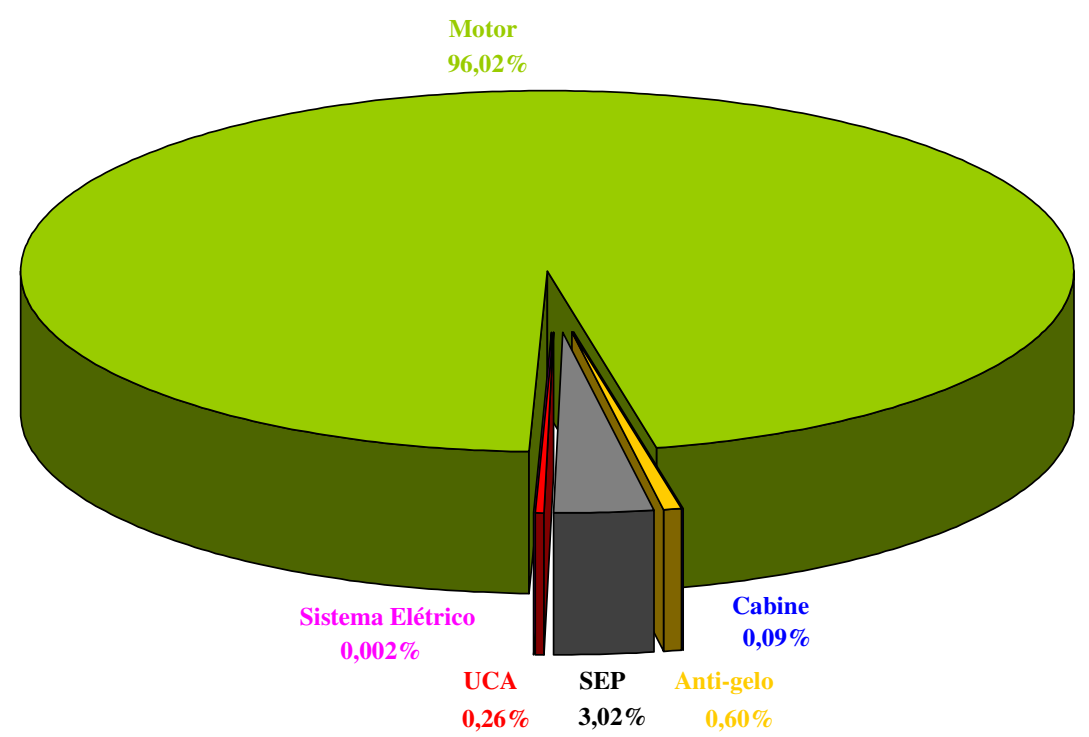

Figura 9.3: Distribuição das irreversibilidades do avião com sistemas convencionais durante a fase de espera a $4572 \mathrm{~m}$, com sistema de antigelo ligado.

O comportamento da versão mais elétrica é semelhante, sendo o motor responsável pela maior parte da exergia destruída nas mesmas fases de voo (Figura 9.4 e Figura 9.5). Entretanto, nota-se que a eliminação do sistema de extração pneumática diminui a parcela de irreversibilidades associadas aos sistemas, visto que o mesmo é a maior fonte de irreversibilidades dentre os sistemas do avião com sistemas convencionais.

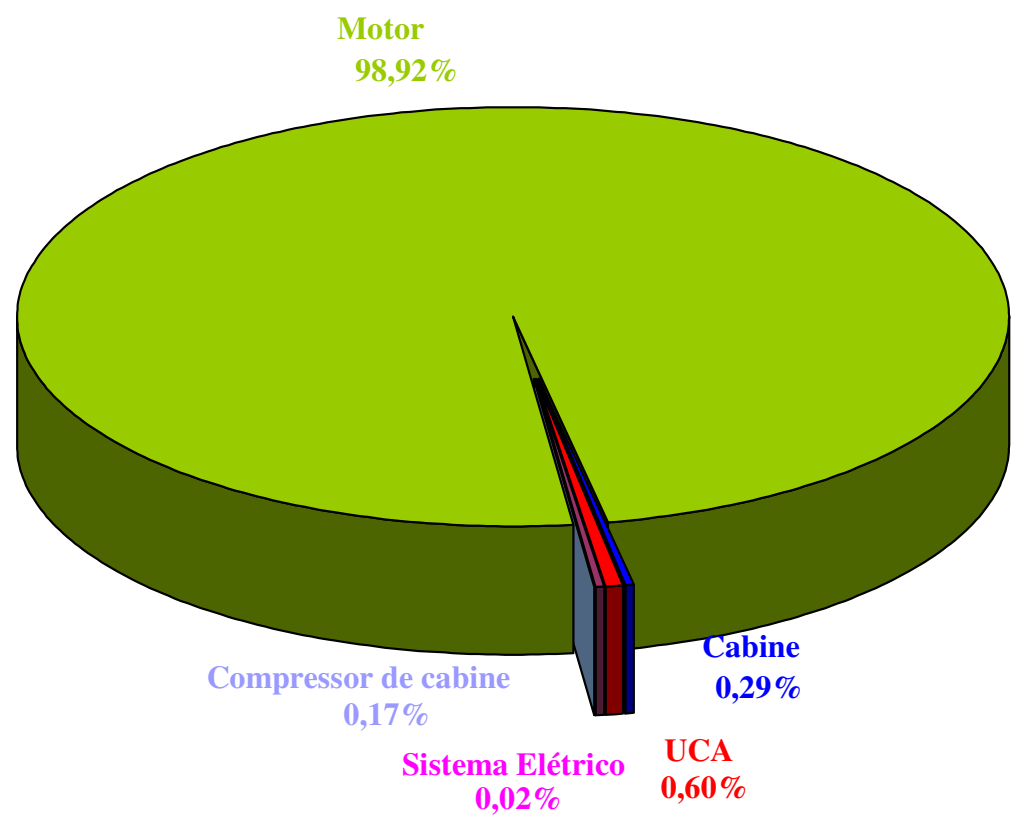

Figura 9.4: Distribuição das irreversibilidades o avião com sistemas mais elétricos durante a fase de cruzeiro a $11277 \mathrm{~m}$, com sistema de antigelo desligado. 
De uma maneira geral, observa-se que os sistemas mais elétricos são mais eficientes pois a soma das irreversibilidades associada aos sistemas exceto motor, caiu de 1,82\% para $1,08 \%$ em cruzeiro e, de $4,1 \%$ para $0,64 \%$ em espera. Isto se deve à substituição do sistema de extração pneumática por compressor de cabine e do sistema de antigelo a ar quente nas superfícies de controle (asa e empenagem) por aquecedores elétricos. Os valores absolutos de taxas de irreversibilidades obtidos são mostrados na Tabela 9.1 à Tabela 9.4.

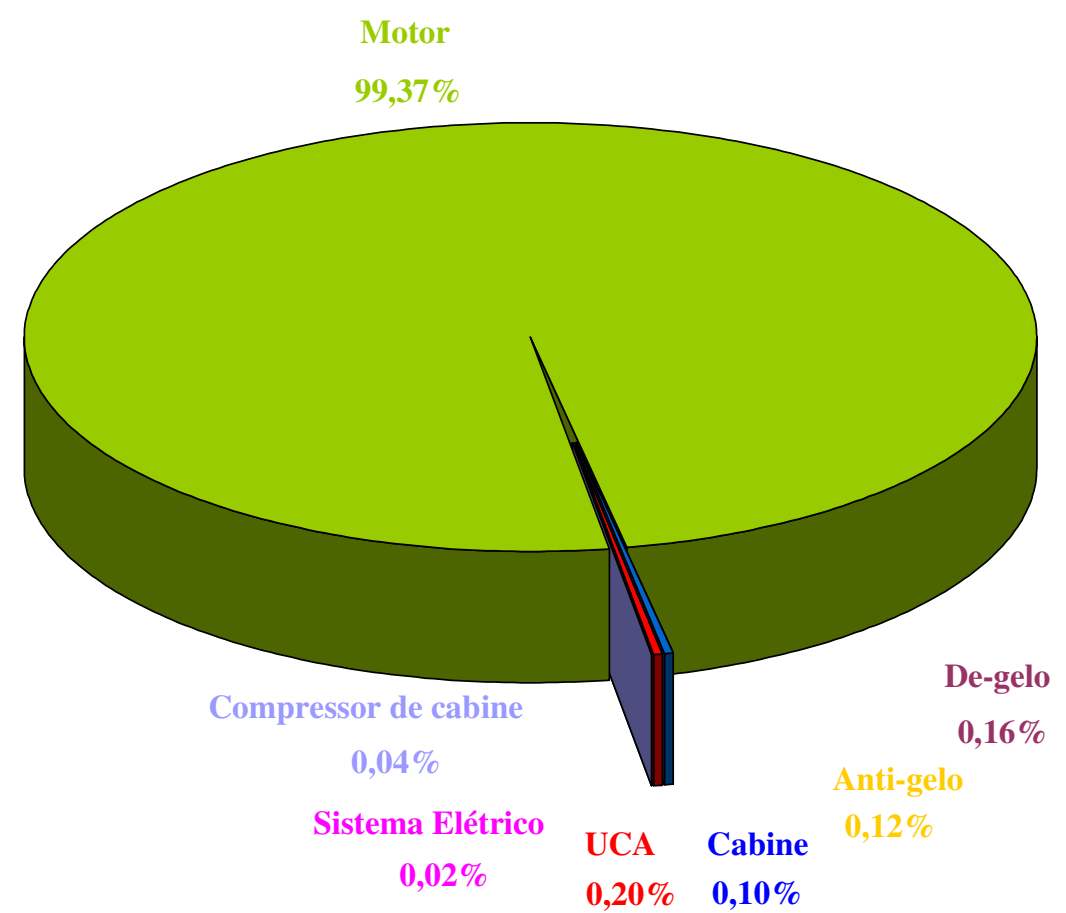

Figura 9.5: Distribuição das irreversibilidades do avião com sistemas mais elétricos durante a fase de espera a $4572 \mathrm{~m}$, com sistema de antigelo ligado.

A exergia destruída da missão pode ser analisada em cada fase de voo por meio de uma análise integral que considera as taxas de irreversibilidades totais dos sistemas multiplicadas pelo tempo de cada fase. Essa distribuição é influenciada pela taxa de destruição de exergia (irreversibilidades) e pela duração de cada fase de voo. Pode-se dizer que a fase que voo que possui a maior taxa de destruição de exergia (vide Tabela 9.1 à Tabela 9.4) é a decolagem, seguida por espera, subida, cruzeiro, descida e aproximação e pouso. A fase de cruzeiro tem duração de 40 minutos, a fase de subida tem duração de 18 minutos e espera tem duração de 22 minutos. Como resultado, a Figura 9.6 mostra que a fase de voo que 
mais destrói exergia é a fase de espera $(33,77 \%)$, seguida da fase de cruzeiro $(31,44 \%)$ e subida $(22,46 \%)$.

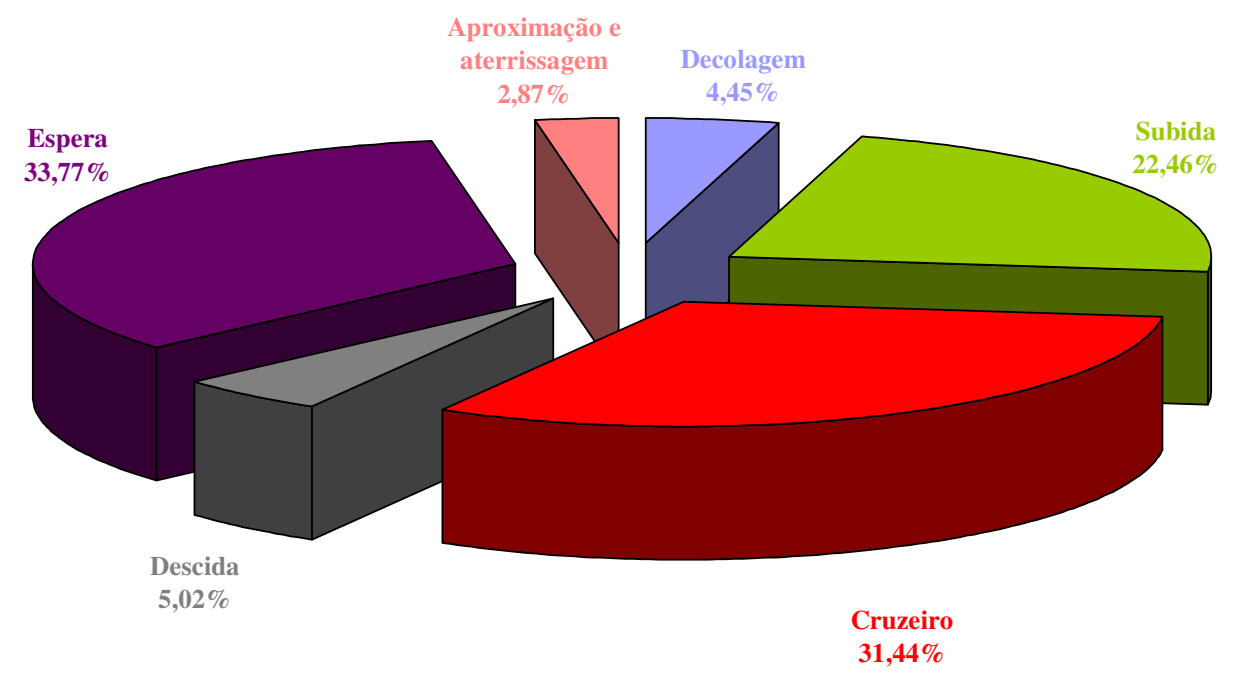

Figura 9.6: Distribuição da exergia destruída por fase de voo para o avião com sistemas convencionais.

A distribuição dos valores para o avião com sistemas mais elétricos é semelhante e está indicada na Figura 9.7. Deve-se destacar que a fase de espera varia com a missão, sendo influenciada pelo tráfego aéreo. Os gráficos mostram que sempre que possível deve-se evitar esta fase que apresenta altas irreversibilidades.e contribui significativamente para a ineficiência de uma missão.

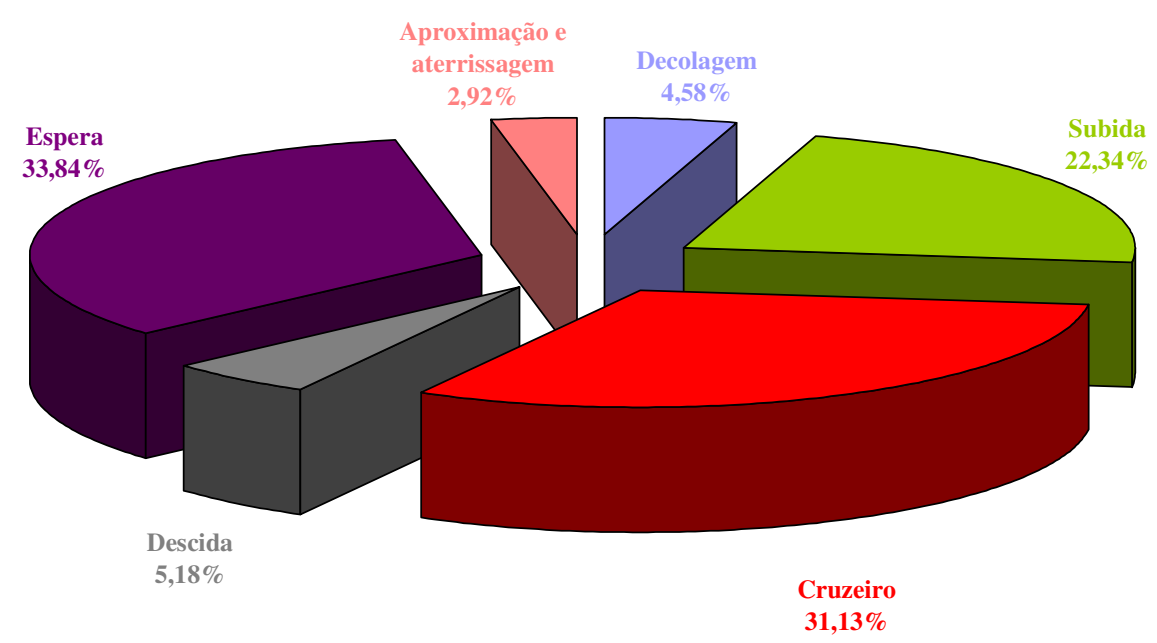

Figura 9.7: Distribuição da exergia destruída por fase de voo para o avião com sistemas mais elétricos. 
Tabela 9.1: Irreversibilidades associadas aos sistemas convencionais (sistema de proteção contra gelo desligado) ${ }^{1}$.

\begin{tabular}{|c|c|c|c|c|c|c|c|c|}
\hline \multirow{2}{*}{ Fase de voo } & \multirow{2}{*}{$\begin{array}{c}\text { Altitude } \\
\text { [m] }\end{array}$} & \multicolumn{7}{|c|}{ Irreversibilidades [kW] } \\
\hline & & SEP & UCA & Cabine & Sistema Elétrico & Antigelo & Motor & Total \\
\hline 1 - Decolagem & 0 & 105,90 & 35,62 & 6,23 & 0,20 & 0,00 & 14635,00 & 14782,95 \\
\hline 2 - Subida & 6096 & 53,90 & 26,12 & 9,13 & 0,20 & 0,00 & 9745,00 & 9834,35 \\
\hline 3 - Subida & 10668 & 54,38 & 38,82 & 17,02 & 0,20 & 0,00 & 6263,00 & 6373,42 \\
\hline 4 - Cruzeiro & 11277,6 & 54,86 & 41,16 & 17,35 & 0,20 & 0,00 & 6137,00 & 6250,57 \\
\hline 5 - Cruzeiro & 12496,8 & 48,04 & 39,53 & 18,15 & 0,20 & 0,00 & 5066,00 & 5171,92 \\
\hline 6 - Descida & 10668 & 14,97 & 36,66 & 13,76 & 0,20 & 0,00 & 3930,00 & 3995,59 \\
\hline 7 - Descida & 6096 & 13,26 & 29,07 & 8,50 & 0,20 & 0,00 & 4301,00 & 4352,03 \\
\hline 8 - Espera & 4572 & 49,97 & 27,44 & 9,65 & 0,20 & 0,00 & 10119,00 & 10206,26 \\
\hline $\begin{array}{l}9 \text { - Aproximação e } \\
\text { aterrissagem }\end{array}$ & 0 & 6,02 & 34,84 & 7,05 & 0,20 & 0,00 & 3129,00 & 3177,11 \\
\hline
\end{tabular}

Tabela 9.2: Irreversibilidades associadas aos sistemas convencionais (sistema de proteção contra gelo ligado) ${ }^{1}$.

\begin{tabular}{|c|c|c|c|c|c|c|c|c|}
\hline \multirow{2}{*}{ Fase de voo } & \multirow{2}{*}{$\begin{array}{c}\text { Altitude } \\
{[\mathrm{m}]}\end{array}$} & \multicolumn{7}{|c|}{ Irreversibilidades [kW] } \\
\hline & & SEP & UCA & Cabine & Sistema Elétrico & Antigelo & Motor & Total \\
\hline 1 - Decolagem & 0 & 341,60 & 35,62 & 6,23 & 0,20 & 52,55 & 14662,00 & 15098,20 \\
\hline 2 - Subida & 6096 & 234,00 & 26,12 & 9,13 & 0,20 & 64,30 & 9895,00 & 10228,75 \\
\hline 3 - Subida & 10668 & 54,38 & 38,82 & 17,02 & 0,20 & 0,00 & 6263,00 & 6373,42 \\
\hline 4 - Cruzeiro & 11277,6 & 54,86 & 41,16 & 17,35 & 0,20 & 0,00 & 6137,00 & 6250,57 \\
\hline 5 - Cruzeiro & 12496,8 & 48,04 & 39,53 & 18,15 & 0,20 & 0,00 & 5066,00 & 5171,92 \\
\hline 6 - Descida & 10668 & 14,97 & 36,66 & 13,76 & 0,20 & 0,00 & 3930,00 & 3995,59 \\
\hline 7 - Descida & 6096 & 63,26 & 29,07 & 8,50 & 0,20 & 65,78 & 4253,00 & 4419,81 \\
\hline 8 - Espera & 4572 & 318,30 & 27,44 & 9,65 & 0,20 & 62,94 & 10110,00 & 10528,53 \\
\hline $\begin{array}{l}9 \text { - Aproximação e } \\
\text { aterrissagem }\end{array}$ & 0 & 22,97 & 36,42 & 7,05 & 0,20 & 54,46 & 3179,00 & 3300,10 \\
\hline
\end{tabular}

${ }^{1}$ Valores relacionados ao funcionamento de um motor, durante operação usual com dois motores. 
Tabela 9.3: Irreversibilidades associadas aos sistemas mais elétricos (sistema de proteção contra gelo desligado) ${ }^{2}$.

\begin{tabular}{|c|c|c|c|c|c|c|c|c|c|}
\hline \multirow[b]{2}{*}{ Fase de voo } & \multirow[b]{2}{*}{ Altitude [m] } & \multicolumn{8}{|c|}{ Irreversibilidades [kW] } \\
\hline & & UCA & $\begin{array}{c}\text { Compressor de } \\
\text { Cabine }\end{array}$ & Cabine & $\begin{array}{l}\text { Sistema } \\
\text { Elétrico }\end{array}$ & $\begin{array}{c}\text { Antigelo } \\
\text { (motor) }\end{array}$ & $\begin{array}{c}\text { Degelo } \\
\text { (elétrico) }\end{array}$ & Motor & Total \\
\hline 1 - Decolagem & 0 & 29,60 & 6,12 & 5,68 & 1,19 & 0,00 & 0,00 & 16486,00 & 16528,58 \\
\hline 2 - Subida & 6096 & 22,54 & 5,98 & 9,37 & 0,91 & 0,00 & 0,00 & 9757,00 & 9795,79 \\
\hline 3 - Subida & 10668 & 34,63 & 9,35 & 17,36 & 1,34 & 0,00 & 0,00 & 6249,00 & 6311,68 \\
\hline 4 - Cruzeiro & 11277,6 & 37,22 & 10,46 & 17,82 & 1,39 & 0,00 & 0,00 & 6118,00 & 6184,89 \\
\hline 5 - Cruzeiro & 12496,8 & 38,03 & 10,34 & 18,73 & 1,47 & 0,00 & 0,00 & 5050,00 & 5118,57 \\
\hline 6 - Descida & 10668 & 35,19 & 9,74 & 15,65 & 1,30 & 0,00 & 0,00 & 4087,50 & 4149,38 \\
\hline 7 - Descida & 6096 & 24,36 & 6,50 & 8,04 & 0,90 & 0,00 & 0,00 & 4349,00 & 4388,79 \\
\hline 8 - Espera & 4572 & 23,11 & 5,58 & 9,85 & 1,01 & 0,00 & 0,00 & 10180,00 & 10219,54 \\
\hline $\begin{array}{l}9 \text { - Aproximação e } \\
\text { aterrissagem }\end{array}$ & 0 & 29,91 & 6,28 & 5,68 & 1,19 & 0,00 & 0,00 & 3194,00 & 3237,05 \\
\hline
\end{tabular}

Tabela 9.4: Irreversibilidades associadas aos sistemas mais elétricos (sistema de proteção contra gelo ligado)².

\begin{tabular}{|c|c|c|c|c|c|c|c|c|c|}
\hline \multirow[b]{2}{*}{ Fase de voo } & \multirow[b]{2}{*}{ Altitude [m] } & \multicolumn{8}{|c|}{ Irreversibilidades [kW] } \\
\hline & & UCA & $\begin{array}{c}\text { Compressor de } \\
\text { Cabine }\end{array}$ & Cabine & $\begin{array}{l}\text { Sistema } \\
\text { Elétrico }\end{array}$ & $\begin{array}{c}\text { Antigelo } \\
\text { (motor) }\end{array}$ & $\begin{array}{c}\text { Degelo } \\
\text { (elétrico) }\end{array}$ & Motor & Total \\
\hline 1 - Decolagem & 0 & 29,60 & 6,12 & 5,68 & 1,82 & 10,29 & 17,57 & 16476,00 & 16547,08 \\
\hline 2 - Subida & 6096 & 22,54 & 5,98 & 9,37 & 1,55 & 12,48 & 16,01 & 9786,00 & 9853,92 \\
\hline 3 - Subida & 10668 & 34,63 & 9,35 & 17,36 & 1,34 & 0,00 & 1,00 & 6273,00 & 6336,68 \\
\hline 4 - Cruzeiro & 11277,6 & 37,22 & 10,46 & 17,82 & 1,39 & 0,00 & 1,00 & 6137,00 & 6204,89 \\
\hline 5 - Cruzeiro & 12496,8 & 38,03 & 10,34 & 18,73 & 1,47 & 0,00 & 1,00 & 5077,00 & 5146,57 \\
\hline 6 - Descida & 10668 & 35,19 & 9,74 & 15,65 & 1,30 & 0,00 & 1,00 & 4092,50 & 4155,38 \\
\hline 7 - Descida & 6096 & 24,36 & 6,50 & 8,04 & 1,54 & 12,74 & 16,16 & 4384,00 & 4453,33 \\
\hline 8 - Espera & 4572 & 23,11 & 5,58 & 9,85 & 1,65 & 12,22 & 16,18 & 10194,00 & 10262,58 \\
\hline $\begin{array}{l}9 \text { - Aproximação e } \\
\text { aterrissagem }\end{array}$ & 0 & 29,91 & 6,28 & 5,68 & 1,82 & 10,64 & 17,57 & 3201,00 & 3272,90 \\
\hline
\end{tabular}

${ }^{2}$ Valores relacionados ao funcionamento de um motor, durante operação usual com dois motores. 


\subsubsection{Eficiências exergéticas}

A Figura 9.8 e a Figura 9.9 mostram, respectivamente, a eficiência exergética dos sistemas estudados durante o voo, com e sem a operação do sistema de proteção contra gelo. A eficiência exergética do motor é maior durante a fase de cruzeiro, evidenciando que, nessa fase, o motor opera próximo de sua condição de projeto. Comportamento semelhante é verificado para a UCA devido à menor temperatura do ar de impacto usado no trocador de calor em altitudes elevadas. Este resultado está de acordo com os obtidos por Conceição et al. (2007).

As mesmas figuras indicam que as eficiências do SEP são maiores nas fases de descida e aproximação pois nessas fases a aeronave está desacelerando e o motor está em baixa rotação ou marcha lenta, isto faz com que a temperatura e pressão do ar extraído do compressor e ventilador estejam mais próximas dos valores requeridos pelos consumidores.

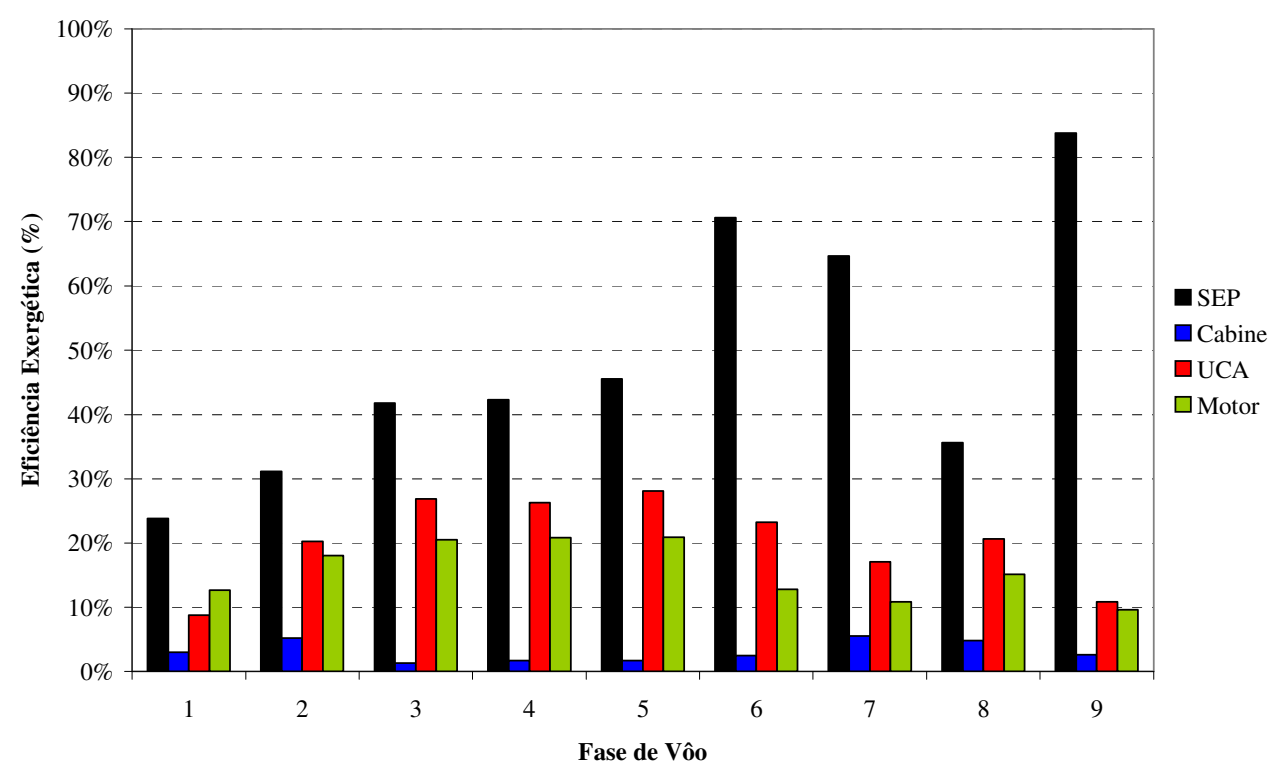

Figura 9.8: Eficiência exergética do avião com sistemas convencionais durante a missão com o sistema de antigelo desligado.

Por sua vez a eficiência exergética do sistema antigelo varia pouco nas fases em que está em operação. Este fato é conseqüência da não otimização da operação desse sistema para 
diferentes condições de formação de gelo e altitudes de voo. Ou seja, ele é dimensionado para as condições mais severas de operação.

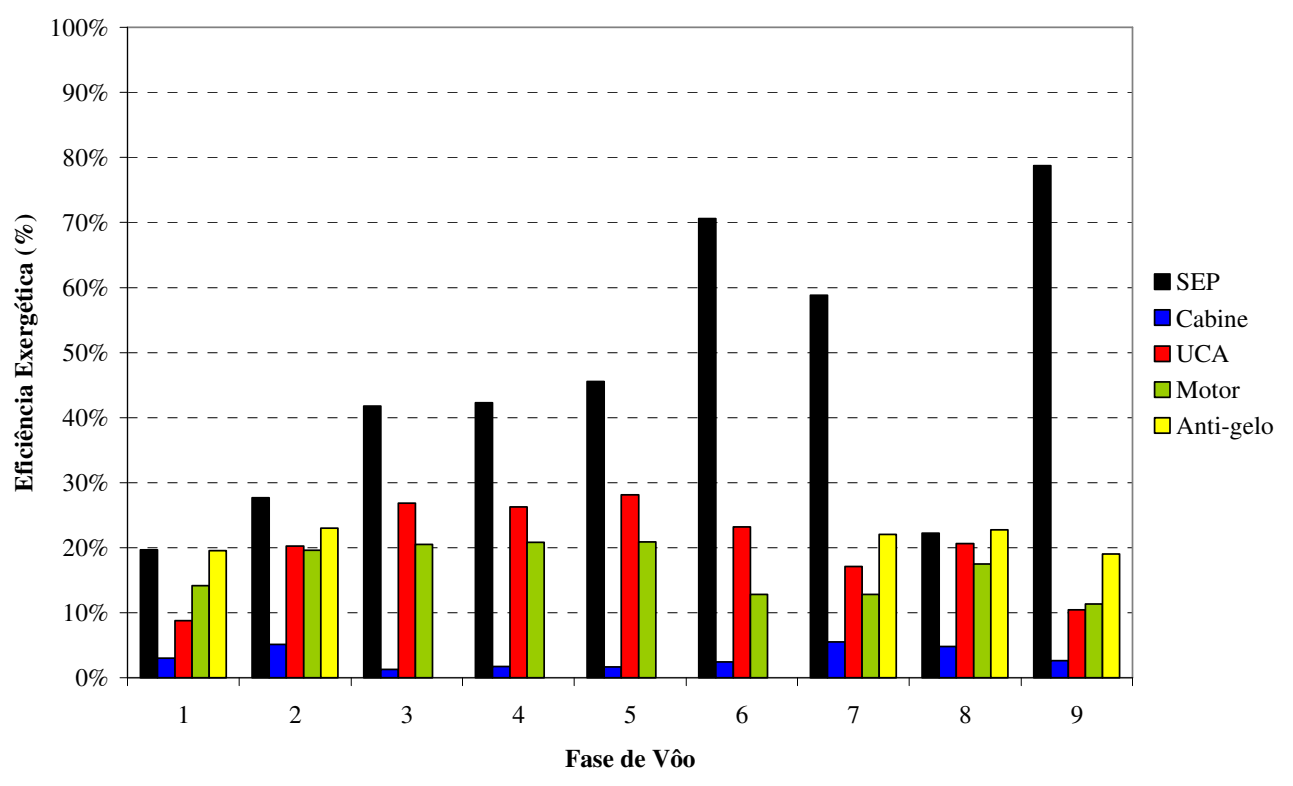

Figura 9.9: Eficiência exergética do avião com sistemas convencionais durante a missão com o sistema de antigelo ligado.

Os dados de rendimento para o avião com sistemas mais elétricos são observados na Figura 9.10 e na Figura 9.11, com sistema de proteção contra gelo desligado e ligado, respectivamente. A eficiência exergética do motor é maior em cruzeiro tornando-se máxima em pontos próximos ao ponto de projeto. Isto significa que o modelo de motor desse avião possui comportamento similar ao motor do avião com sistemas convencionais, o que vai ao encontro da abordagem utilizada na confecção dos modelos. A eficiência exergética da UCA também é máxima em cruzeiro e tem o mesmo comportamento que a UCA do avião com sistemas convencionais. Este resultado também reflete a hipótese de utilização da mesma abordagem na modelagem da UCA convencional e mais elétrica. 


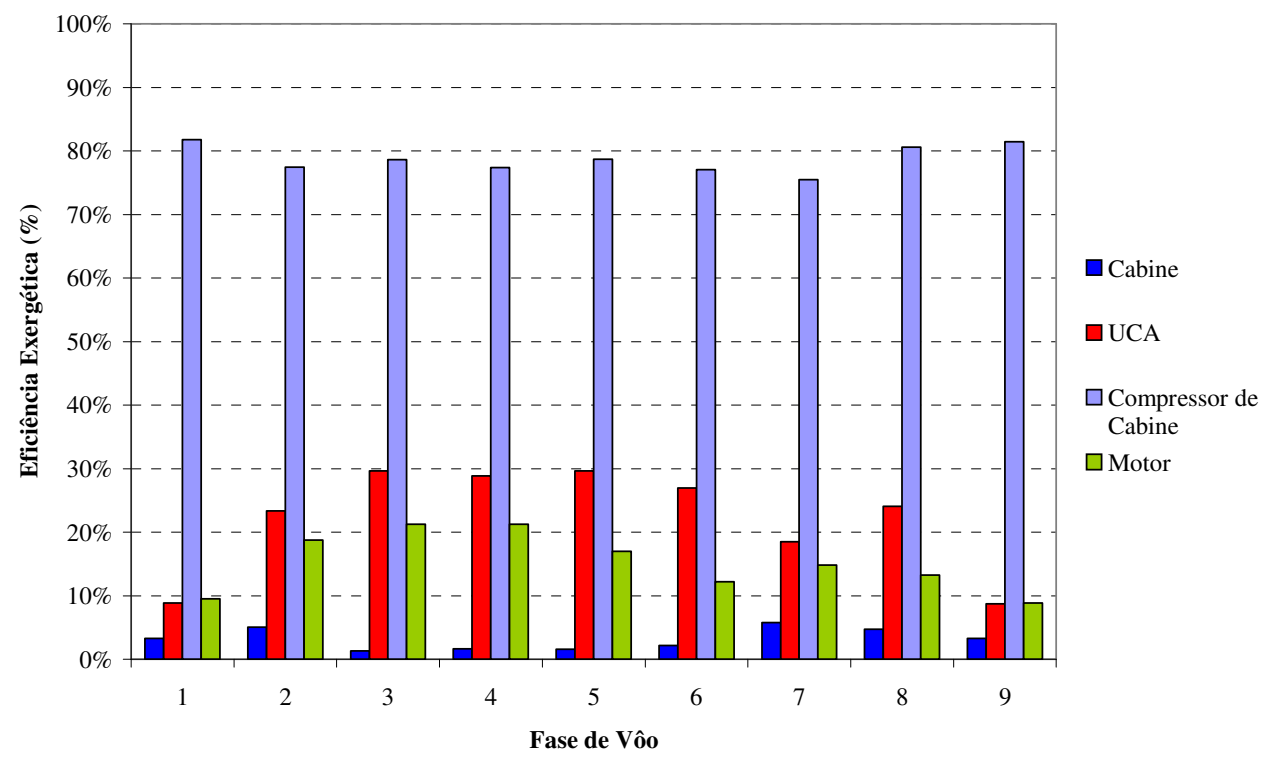

Figura 9.10: Eficiência exergética do avião com sistemas mais elétricos durante a missão com o sistema de antigelo desligado.

O compressor de cabine é o equipamento que possui os maiores rendimentos exergéticos entre os sistemas, ficando entre $76 \%$ e $82 \%$ durante todas as fases de voo. Este resultado evidencia a maior eficiência do sistema se comparado com o SEP, que possui eficiências significativamente menores devido aos processos com maiores irreversibilidades (ajuste de pressão e temperatura do fluxo de ar). A menor taxa de compressão do ar no compressor de cabine, se comparado com o compressor do motor, também contribui para melhorar a eficiência e é mais adequada para os requisitos de ar da UCA.

O sistema de degelo elétrico apresenta maiores eficiências exergéticas do que o sistema convencional a ar quente. $\mathrm{O}$ menor consumo exergético, devido à otimização da operação das mantas de aquecimento, possibilita ao sistema de degelo elétrico melhores rendimentos exergéticos. 


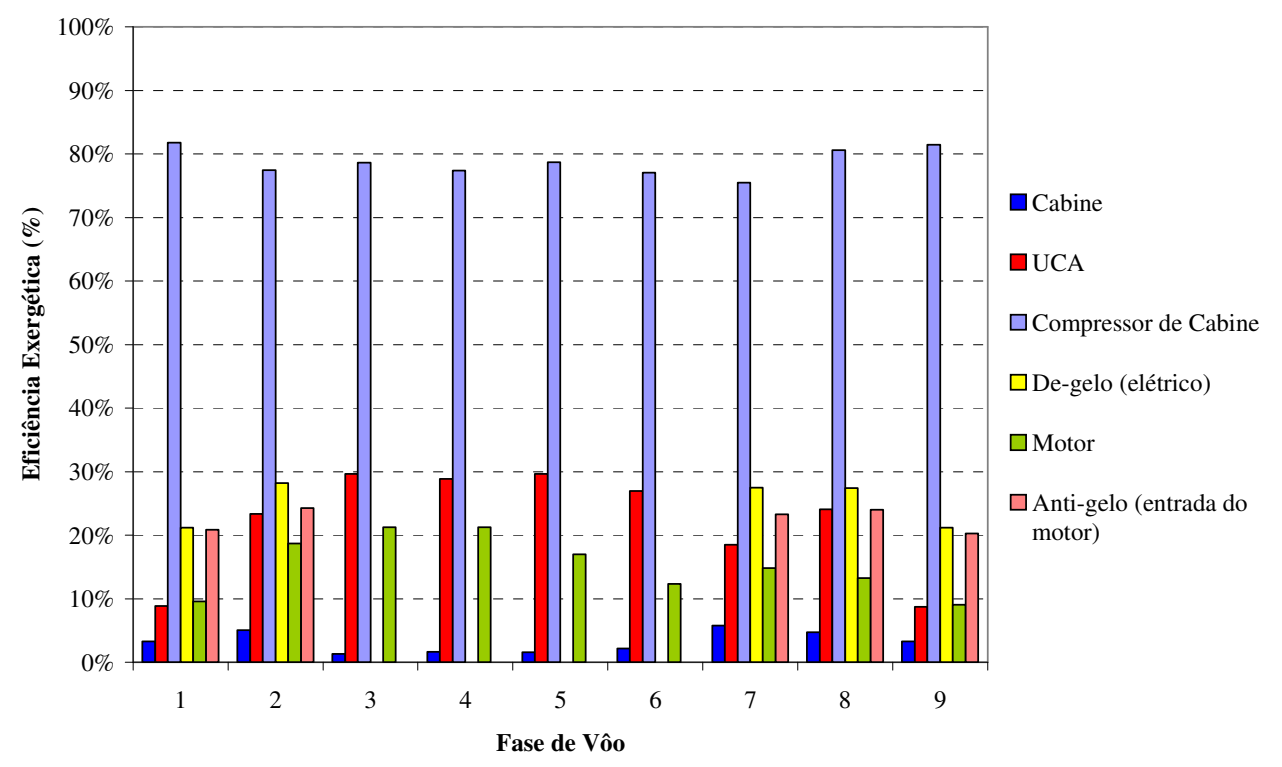

Figura 9.11: Eficiência exergética do avião com sistemas mais elétricos durante a missão com o sistema de antigelo ligado.

A eficiência exergética da missão é calculada por meio de uma análise integral de todos os pontos da missão computando a exergia total destruída ao longo do voo. Para o avião com sistemas convencionais, obteve-se $16,36 \%$ de eficiência para a missão com o sistema de proteção contra gelo desligado e $16,15 \%$ para a missão com a proteção ligada. Estes valores são coerentes com o fato do sistema de antigelo ligado aumentar as taxas de destruição de exergia do SEP e do próprio antigelo (vide Tabela 9.1 e Tabela 9.2). Entretanto, a maior parte da destruição de exergia da missão é proveniente do motor, e o fato de operar com o antigelo ligado ou desligado causa pouco impacto na eficiência exergética da missão.

A eficiência exergética para o avião com sistemas mais elétricos foi de $16,80 \%$ para a missão com o sistema de proteção contra gelo desligado e $16,61 \%$ para a missão com a proteção ligada. Como justificativa, pode-se utilizar os mesmos argumentos das eficiências do avião com sistemas convencionais. Entretanto, nota-se que as eficiências das respectivas missões do avião com sistemas mais elétricos foram maiores que os valores das missões da abordagem convencional. Isto mostra que os sistemas mais elétricos podem contribuir para a melhoria da eficiência do avião. 


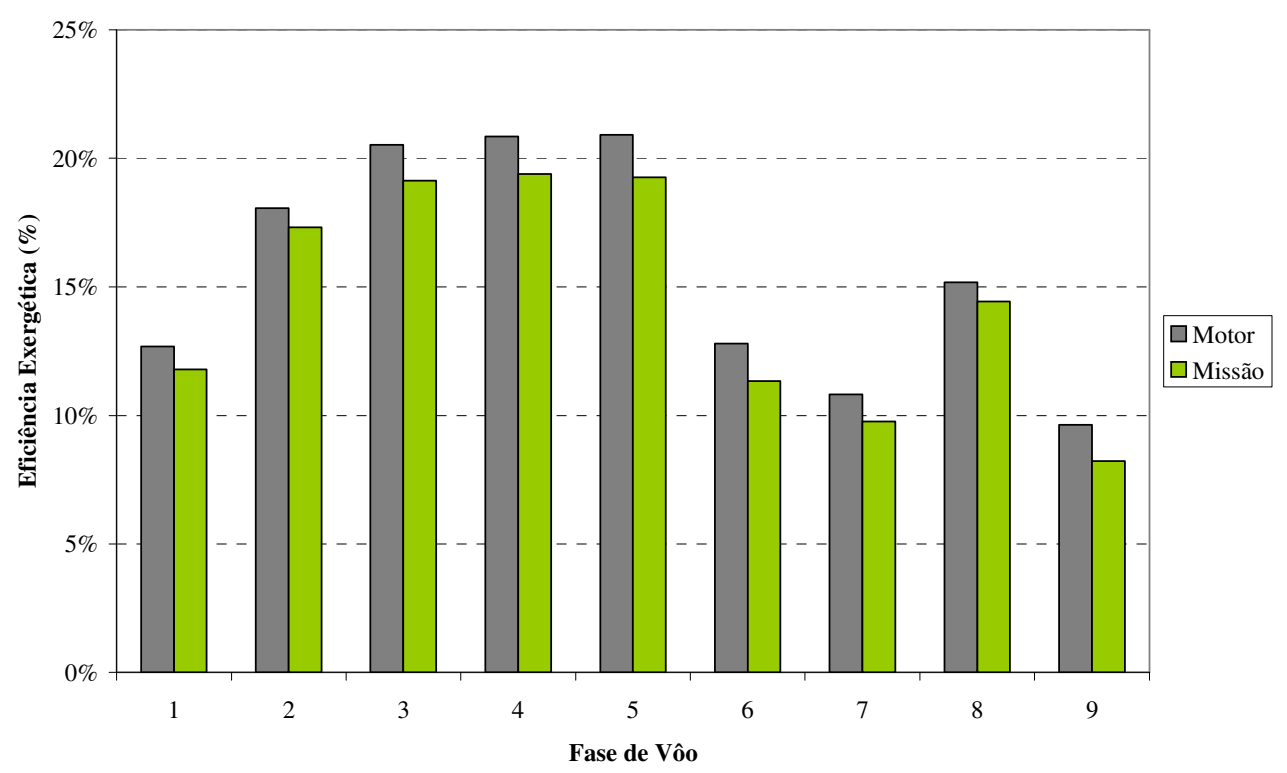

Figura 9.12: Comparação entre eficiência exergética da missão e do motor para o avião com sistemas convencionais (missão com o sistema de antigelo desligado).

A Figura 9.12 e a Figura 9.13 mostram uma comparação entre eficiência exergética do motor e da missão por fase de voo. O valor da eficiência exergética da missão é muito próximo com o valor da eficiência exergética do motor devido ao maior peso deste nas irreversibilidades presentes na missão (vide Tabela 9.1 à Tabela 9.4). Conforme mostrado anteriormente, o motor representa de $96 \%$ a $99 \%$ de toda a exergia destruída nas fases de voo e, conseqüentemente, na missão. Além disso, pode-se notar na Figura 9.6 e na Figura 9.7 que a fase de cruzeiro é a segunda maior em termos de destruição de exergia. Pretende-se então no próximo capítulo investigar mais a fundo o papel do motor na análise global da missão, principalmente durante a fase de cruzeiro que é a fase que pode apresentar maiores variações de tempo. 


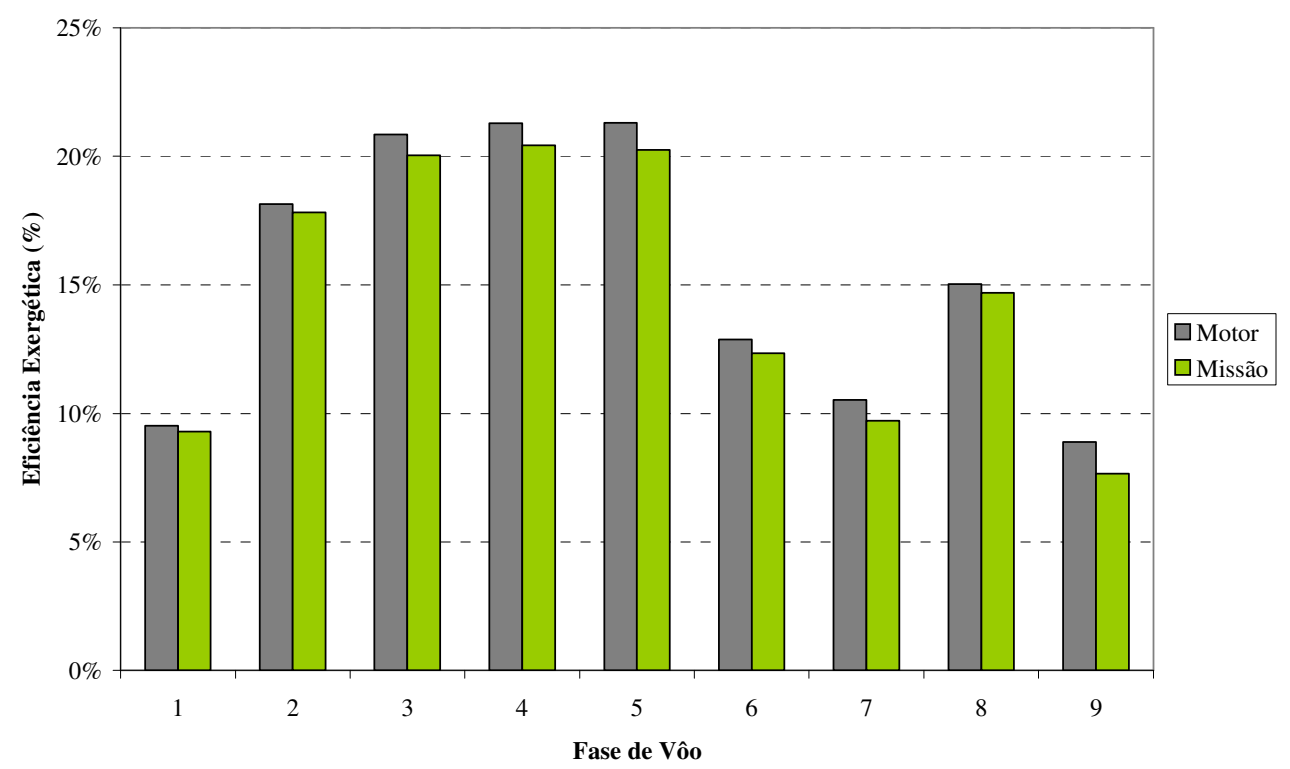

Figura 9.13: Comparação entre eficiência exergética da missão e do motor para o avião com sistemas mais elétricos (missão com o sistema de antigelo desligado).

\subsubsection{Consumo específico de exergia (CEE)}

O consumo específico de exergia indica o impacto da utilização da exergia em cada sistema no consumo de exergia associada ao combustível. A Figura 9.14 mostra, para o avião com sistemas convencionais, a operação com o antigelo desligado e indica que o maior consumidor de exergia, exceto motor, é o SEP, seguido pela UCA e cabine. Os sistemas elétrico e hidráulico são os menores consumidores de exergia nessa operação. A Figura 9.15 mostra, para o avião com sistemas covencionais, a operação com o antigelo ligado e indica que o maior consumidor de exergia, exceto o motor, é o SEP, seguido pelo antigelo, UCA e cabine. Os sistemas elétrico e hidráulico são os menores consumidores de exergia nessa operação.

Os gráficos evidenciam que os sistemas de gerenciamento de ar do avião com sistemas convencionais (SEP, UCA e antigelo) são os maiores consumidores de exergia do avião exceto motor. Além disso, como o SEP distribui ar comprimido para o antigelo e a UCA, o seu CEE varia de acordo com a operação de seus sistemas clientes. 


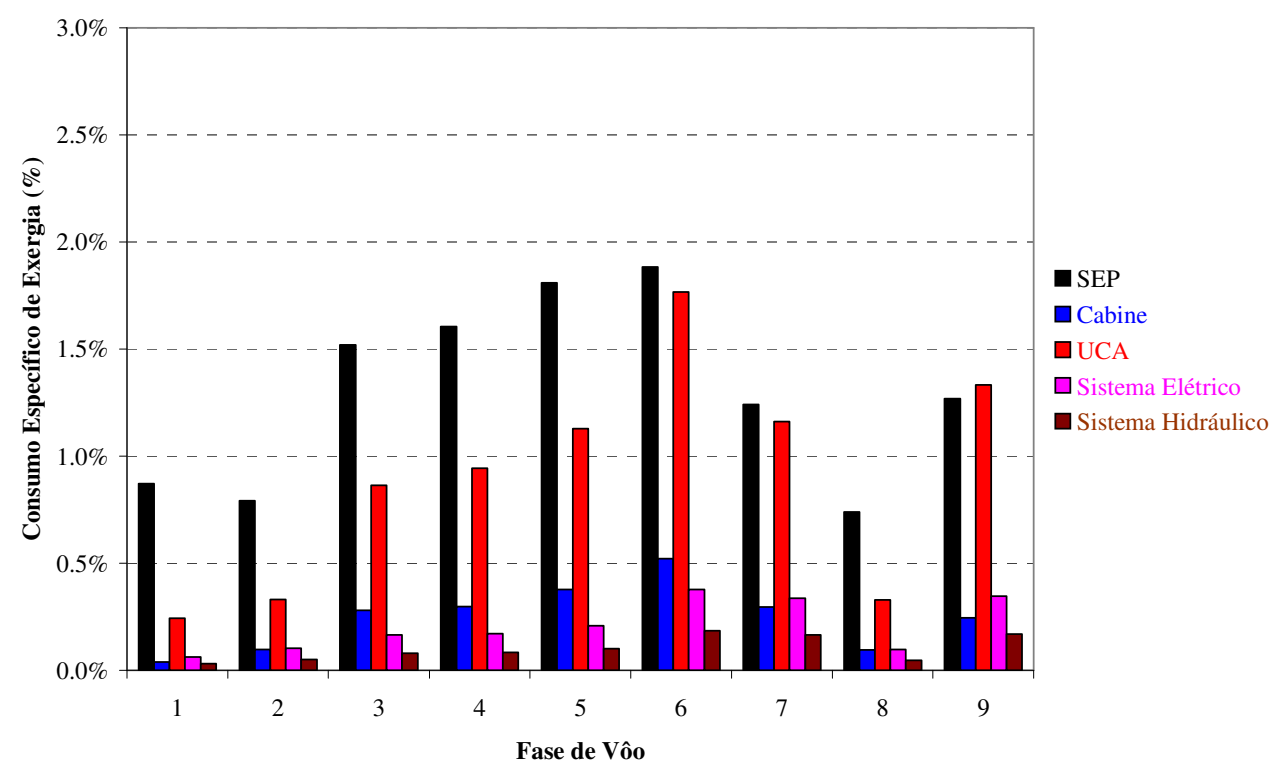

Figura 9.14: Consumo específico de exergia para o avião com sistemas convencionais durante a missão com o sistema de antigelo desligado.

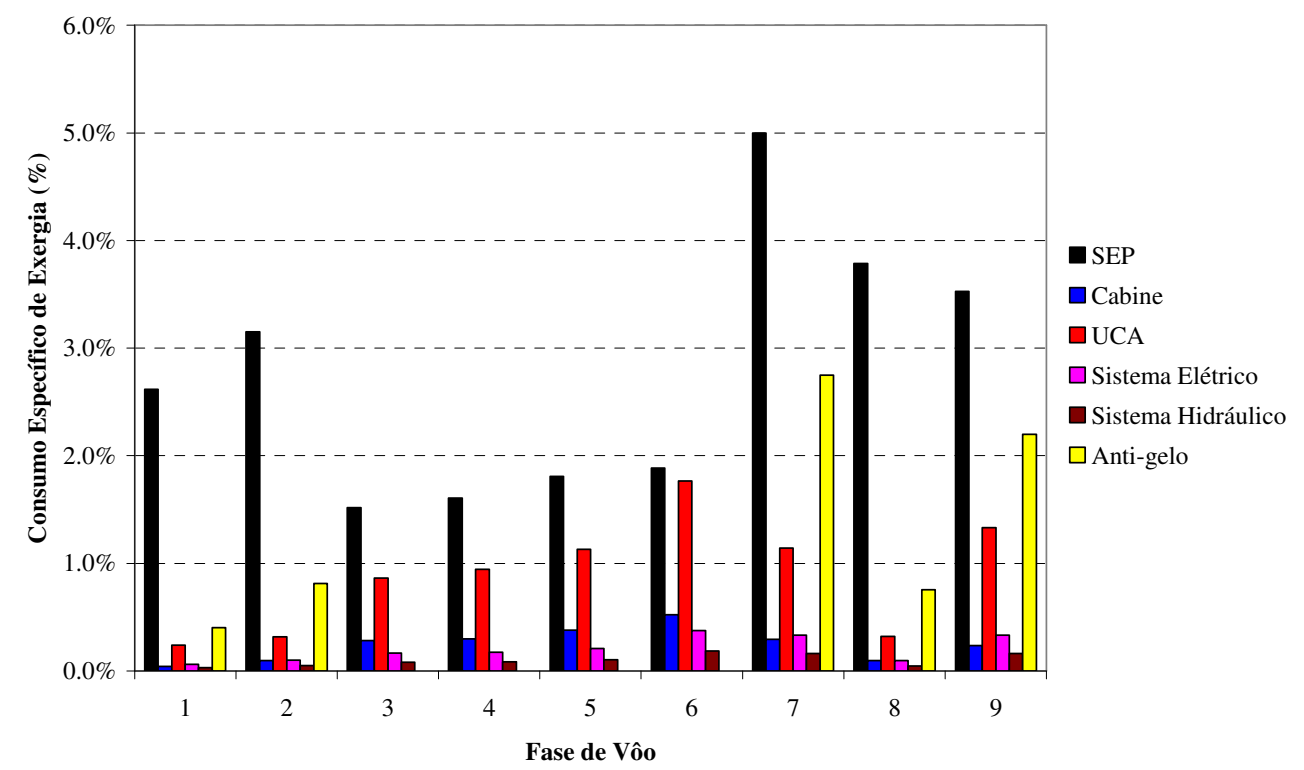

Figura 9.15: Consumo específico de exergia para o avião com sistemas convencionais durante a missão com o sistema de antigelo ligado.

A Figura 9.16 mostra, para o avião com sistemas mais elétricos, a operação com o antigelo desligado e indica que o maior consumidor de exergia em altas altitudes, exceto 
motor, é a UCA, seguido pelo sistema elétrico, compressor de cabine e cabine. O sistema hidráulico é o menor consumidor de exergia nessa operação. Em altas altitudes, a UCA recebe a exergia cinética do ar de impacto que é direcionado aos trocadores de calor, por isso o CEE deste sistema torna-se maior que do sistema elétrico nessas condições A Figura 9.17 mostra, para o avião com sistemas mais elétricos, a operação com a proteção contra gelo ligada e indica que o maior consumidor de exergia, exceto motor, é o sistema elétrico, seguido pela UCA, compressor de cabine, degelo elétrico e antigelo do motor. A cabine e o sistema hidráulico são os menores consumidores de exergia nessa operação. A análise em altas altitudes, quando o sistema de proteção contra gelo não está ligado, é a mesma da Figura 9.16.

Os gráficos evidenciam que o sistema elétrico do avião com sistemas mais elétricos é o maior consumidor de exergia do avião quando o sistema de proteção contra gelo está ligado, e o segundo maior quando o mesmo sistema está desligado. Isto é evidente pois é o sistema elétrico que distribui potência elétrica para os sistemas mais elétricos (compressor de cabine degelo elétrico) e seu CEE varia de acordo com a operação de seus sistemas clientes.

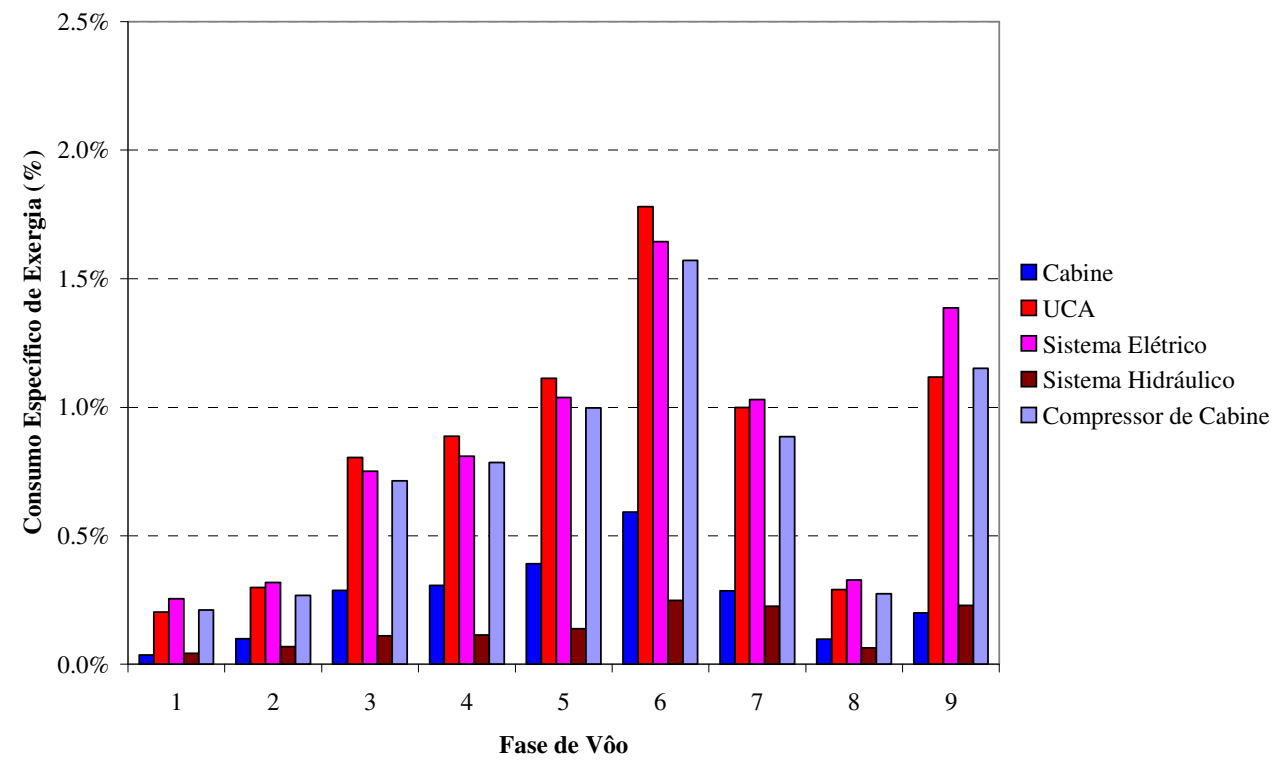

Figura 9.16: Consumo específico de exergia para o avião com sistemas mais elétricos durante a missão com o sistema de antigelo desligado. 


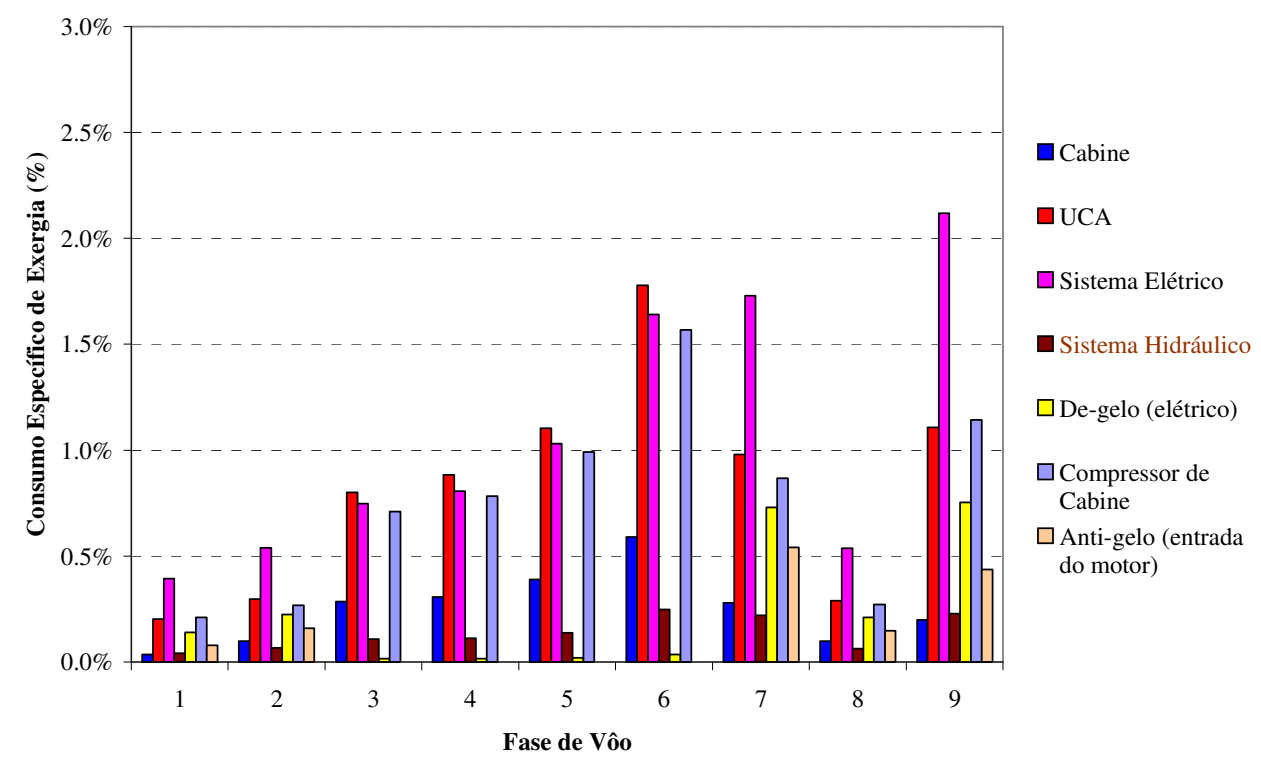

Figura 9.17: Consumo específico de exergia para o avião com sistemas mais elétricos durante a missão com o sistema de antigelo ligado.

O principal efeito útil do motor é a tração, cujo usuário é a estrutura do avião. O fornecimento de potência (pneumática e de eixo) para o funcionamento dos sistemas é secundário. Todavia, sem os sistemas embarcados não seria possível concretizar os voos que ocorrem em altas altitudes, em condições de formação de gelo, com a mesma potência fornecida às superfícies de controle, com a aviônica presente, etc. Calculou-se então o CEE para a estrutura, conforme equação (37). 


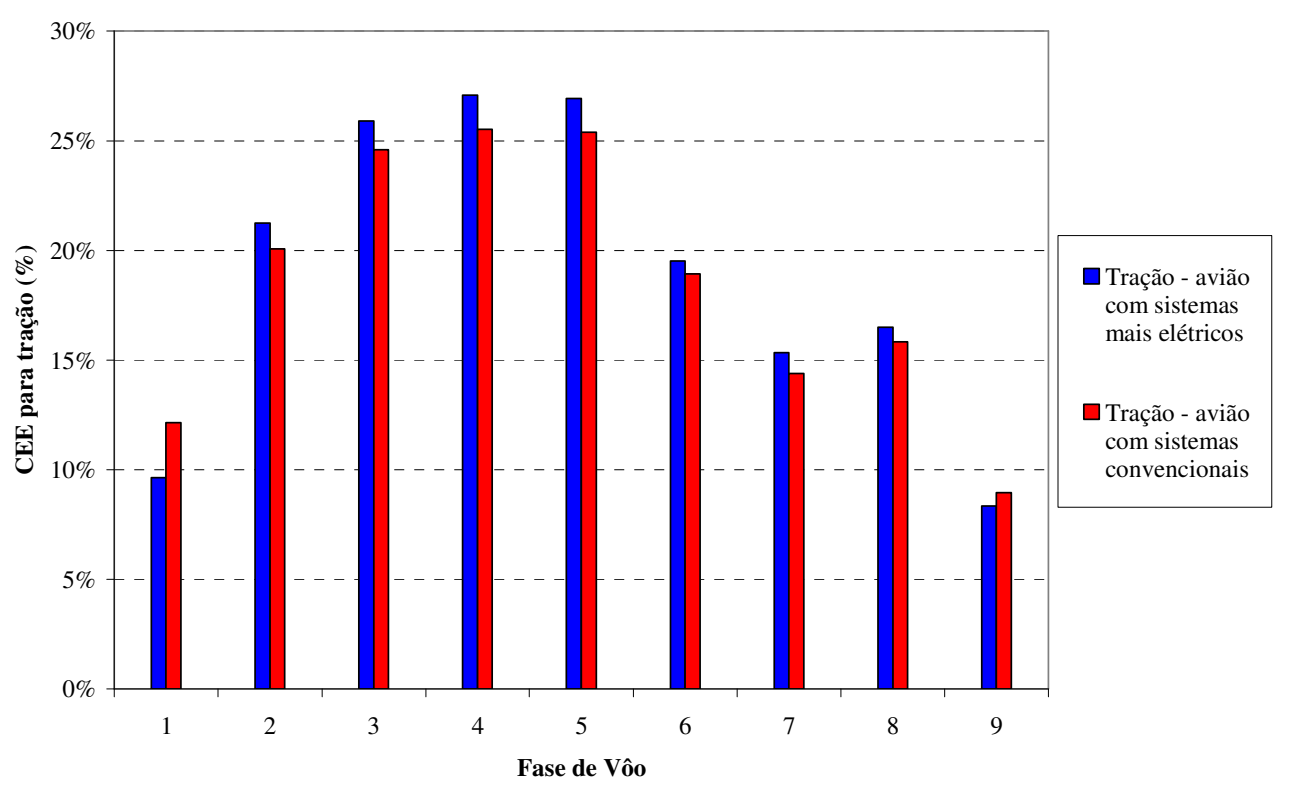

Figura 9.18: Consumo específico de exergia para a estrutura dos aviões com o sistema de antigelo ligado.

A Figura 9.18 mostra que a estrutura possui o maior CEE, visto que os requisitos exergéticos de tração são muito maiores que os requisitos exergéticos de sistemas. Isto indica que variações nos requisitos de tração e, conseqüentemente, variações nas exergias relacionadas à tração podem influenciar muito mais o projeto de um novo avião do que modificações relacionadas a sistemas. Os valores de CEE para o avião com sistemas mais elétricos são ligeiramente menores do que os do avião com sistemas convencionais devido ao menor consumo de combustível observado daquele. Conforme já mencionado, neste capítulo usaram-se os mesmos requisitos de tração para ambos os aviões.

\subsubsection{Conclusões da análise exergética}

Os gráficos da análise exergética mostram que há um potencial de melhoria da eficiência exergética e, conseqüentemente, energética de aviões comerciais ao se substituir sistemas convencionais por sistemas mais elétricos.

A análise em nível avião mostra que o SEP apresenta alta irreversibilidade, sendo o sistema que mais destrói exergia na maior parte das fases de voo, após o motor (GANDOLFI et al., 2008). Além disso, é o maior consumidor de exergia entre os sistemas, chegando o CEE 
a 5\% quando o sistema de antigelo está ligado. O sistema de antigelo é a segunda maior fonte de irreversibilidades e possui o segundo maior CEE, chegando a quase $3 \%$.

A proposta de substituir o SEP e o sistema de antigelo por compressor de cabine e sistema de degelo elétrico pode contribuir para a melhoria exergética e energética da aeronave. O compressor de cabine apresenta irreversibilidades bem menores que o SEP e altos rendimentos exergéticos em todas as fases de voo (GANDOLFI et al., 2010). O degelo elétrico apresenta menores irreversibilidades e maiores eficiências exergéticas que o antigelo convencional.

Nota-se pelo cálculo do CEE da estrutura (Figura 9.17) que a exergia associada aos requisitos de tração é muito superior às exergias associadas aos requisitos de sistemas (GANDOLFI et al., 2010). Além disso, o motor é o componente que mais influencia na destruição de exergia total de uma missão, sendo cruzeiro a principal fase. Portanto, é necessário realizar uma análise dedicada do motor que aborda as variações de tração, que são provenientes de variações do peso e arrasto devido à instalação dos sistemas mais elétricos, e a fase de cruzeiro, que é a fase que pode apresentar maiores variações de tempo. 


\section{Análise de Sensibilidade do Motor}

O projeto de sistemas de aeronaves envolve considerações em nível sistema que influenciam o projeto em nível avião. Conforme exposto nos capítulos iniciais deste trabalho, o avião com sistemas mais elétricos pode possuir modificações em sistemas de controle ambiental, sistemas de proteção contra gelo, atuação e comandos de voo que fazem com que o sistema elétrico seja modificado para atender às novas demandas de potência elétrica. A estrutura é influenciada pelos requisitos de instalação e peso dos equipamentos, que serão utilizados na análise de mecânica de voo que considera a movimentação do centro de gravidade ao longo do voo. No final da cadeia de análise está o motor que precisa atender às demandas de potência dos sistemas mais elétricos e requisitos de tração dessa aeronave. Uma análise energética e/ou exergética completa de sistemas aeronáuticos considera as modificações nos requisitos de tração que a instalação dos sistemas mais elétricos exige em nível avião.

A proposta deste capítulo é analisar como as modificações dos requisitos de tração do avião com sistemas mais elétricos e tempo de duração da missão podem influenciar a análise global do motor na missão e, sendo o motor o componente mais impactante na análise exergética global do avião, como estes resultados também representam a análise exergética do avião.

10.1.1. Comparação dos requisitos exergéticos de uma aeronave

Os requisitos exergéticos de tração e extração para sistemas variam ao longo do voo conforme necessidade dos consumidores. A Figura 10.1 mostra a soma das extrações exergéticas do motor para a aeronave com sistemas convencionais e para a aeronave com sistemas mais elétricos. A aeronave com sistemas convencionais utiliza ar comprimido que é direcionado ao sistema de controle ambiental e sistema antigelo, este protege superfícies de sustentadoras e entradas dos motores contra a formação de gelo. A figura mostra o total de extrações exergéticas do motor em termos de potência pneumática e de potência de eixo que aciona os geradores elétricos e as bombas hidráulicas ao longo do voo. Nota-se que as extrações do avião com sistemas convencionais são ligeiramente maiores do que as do avião com sistemas mais elétricos na maior parte do tempo de voo. 


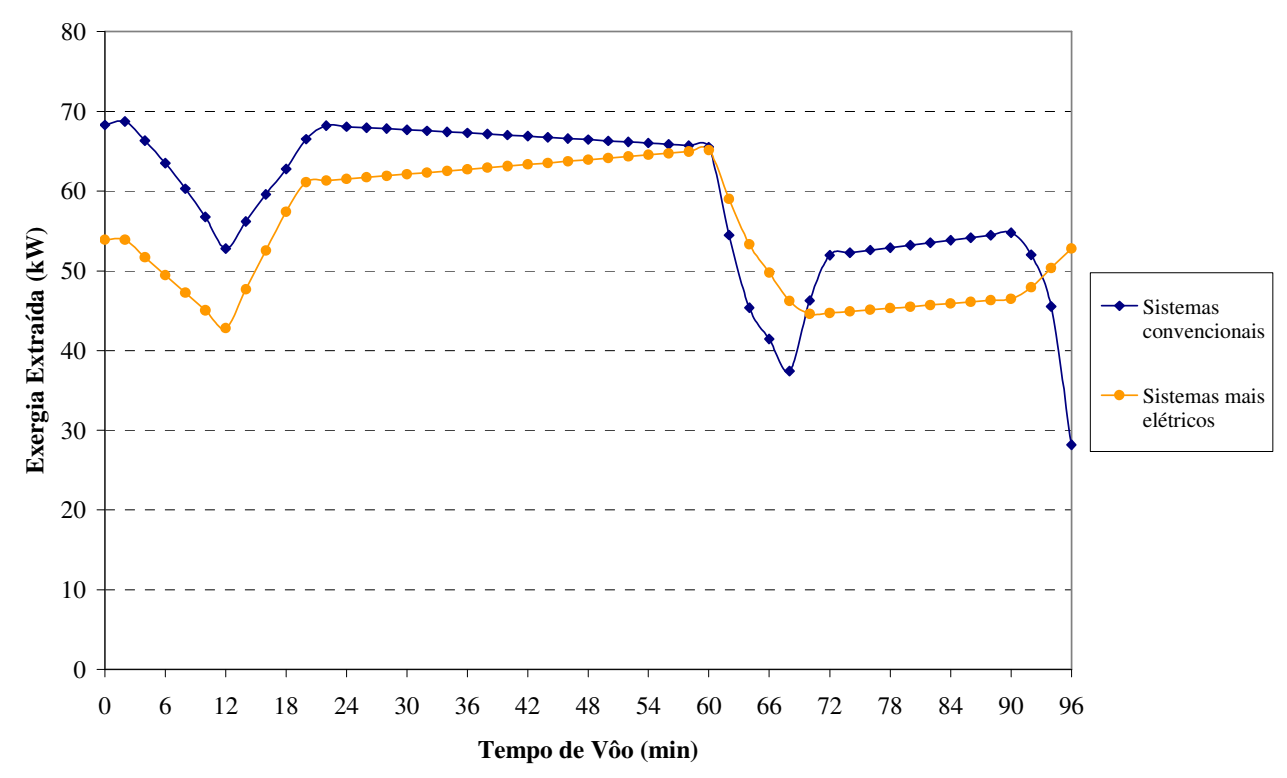

Figura 10.1: Requisitos de extração exergética do motor para os sistemas convencionais e mais elétricos.

A instalação dos sistemas mais elétricos faz com que o peso do avião seja diferente do peso do avião com abordagem convencional de sistemas. A Figura 10.2 mostra os requisitos de tração e a Figura 10.3 mostra os requisitos exergéticos de tração que são fornecidos à estrutura do avião com sistemas convencionais ao longo do mesmo voo. Nesse caso, para auxiliar a análise de sensibilidade dos requisitos exergéticos de tração do avião com o conceito mais elétrico, fez-se uma variação conservativa do peso do avião com sistemas convencionais em $10 \%$ a mais e a menos para calcular, com o auxílio da polar de arrasto, os requisitos de tração associados a estas variações de peso. Foi utilizada a mesma polar de arrasto do avião com abordagem convencional de sistemas sem computar modificações no arrasto devido às novas tomadas de ar do sistema de ar condicionado mais elétrico ou outras modificações no desenho da fuselagem. Todavia, pode-se considerar que as variações dos requisitos de tração obtidas varrem também o impacto no arrasto, pois são conservativas. Com isso, representam-se as modificações de peso e arrasto que o projeto do avião com o conceito mais elétrico de sistemas pode sofrer. 


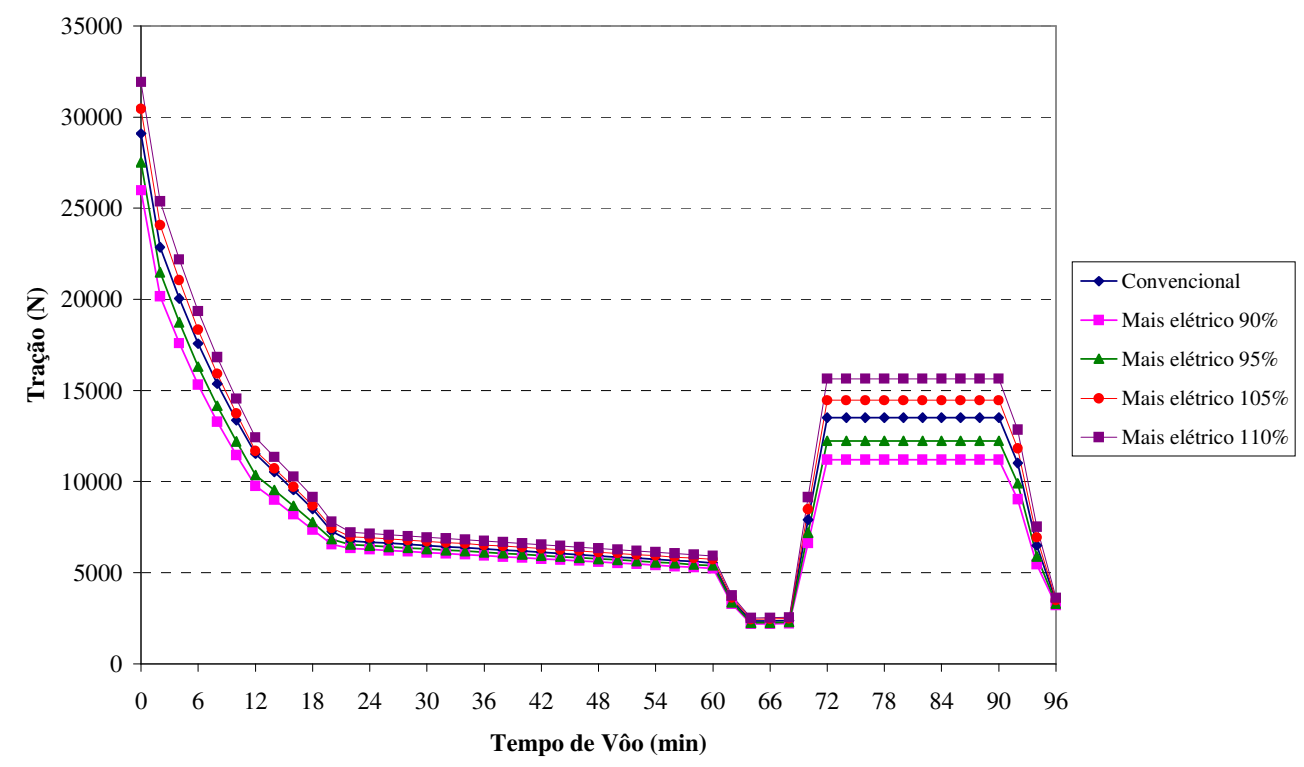

Figura 10.2: Requisitos de tração para o estudo de sensibilidade.

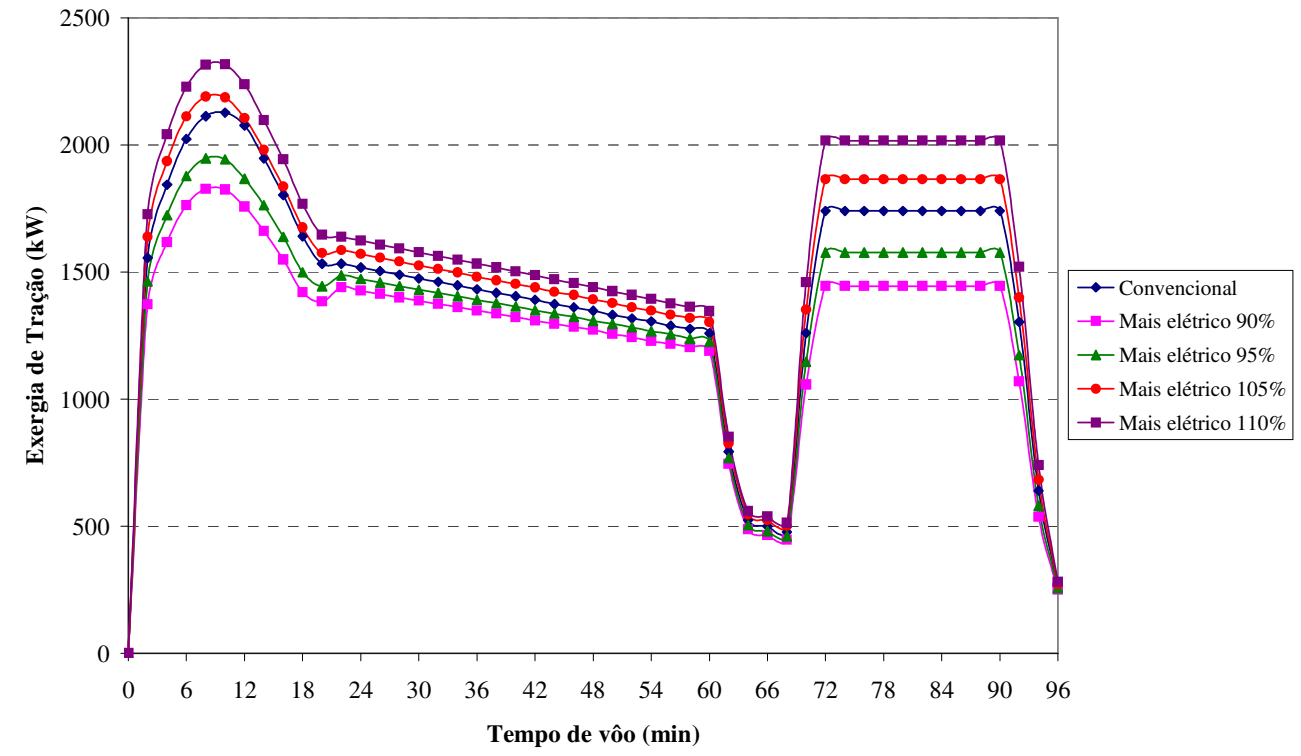

Figura 10.3: Requisitos exergéticos de tração para o estudo de sensibilidade.

Os gráficos anteriores mostram que numa aeronave os requisitos exergéticos de tração são muito superiores aos requisitos de extração exergética para os sistemas, no caso estudado em até 30 vezes aproximadamente. Isto explica a pequena variação do rendimento exergético da missão que foi obtida entre o avião com sistemas convencionais e sua versão com sistemas 
mais elétricos, quando considerados os mesmos requisitos exergéticos de tração para os dois aviões (vide seção 9.2.2)

10.1.2. Comparação da eficiência exergética e consumo de combustível

A análise de sensibilidade mostra que os requisitos exergéticos de tração tem grande influência na análise. A Figura 10.4 mostra como a variação dos requisitos exergéticos de tração modificam a eficiência exergética do motor do avião com sistemas mais elétricos ao longo da missão. Por outro lado, as curvas do avião convencional e mais elétrico $100 \%$ são praticamente iguais.

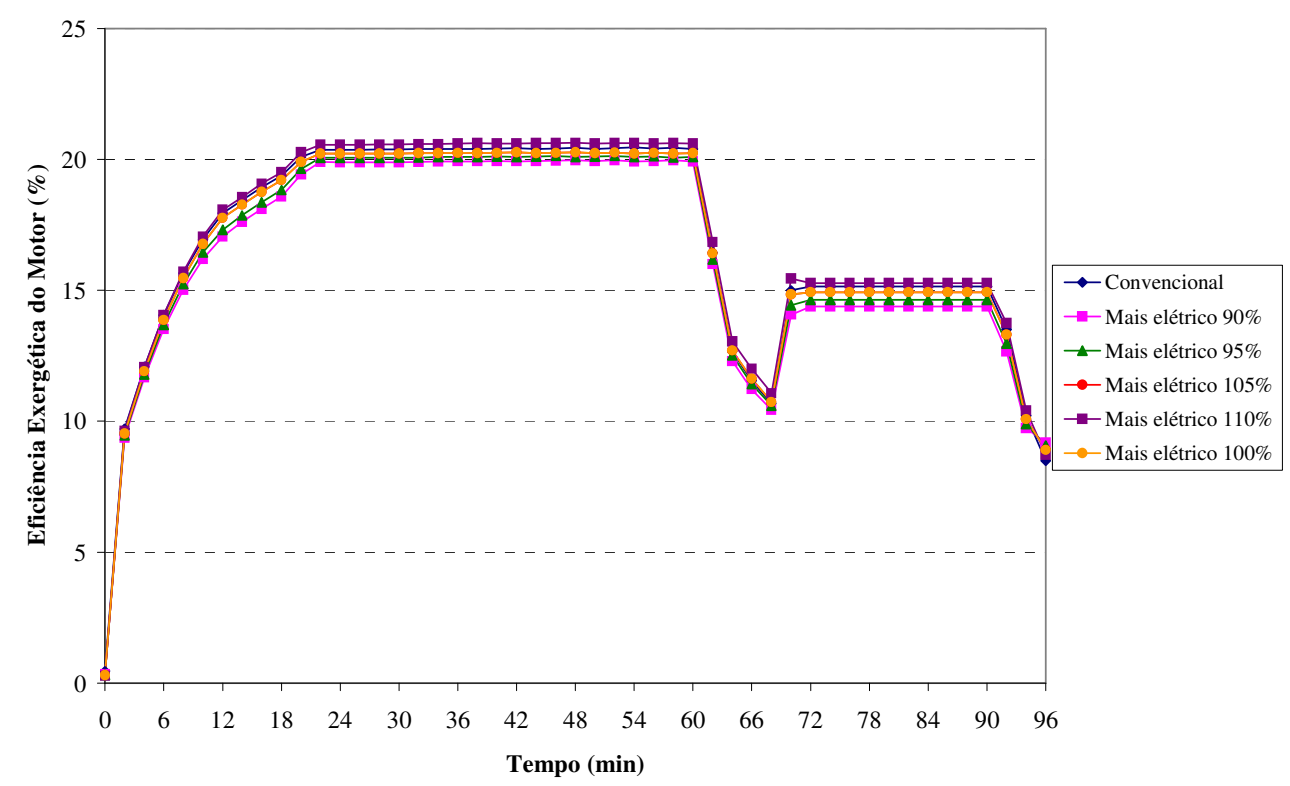

Figura 10.4: Variação da eficiência exergética do motor do avião com sistemas mais elétricos ao longo da missão no estudo de sensibilidade.

A Figura 10.5 mostra variações de eficiências exergéticas do motor resultante para diferentes tempos de missão. Nesse caso, o valor da eficiência é obtido com uma análise integral considerando as diferentes eficiências ao longo da missão e períodos de duração associados, de maneira similar a eficiência exergética da missão. Esta análise considerou que os períodos de decolagem, subida, descida, espera e aproximação e pouso foram mantidos. $\mathrm{O}$ único período que sofreu variações é o cruzeiro. O gráfico mostra que quanto maior o tempo de missão (ou de cruzeiro), mais a eficiência exergética do motor resultante na missão se aproxima da eficiência exergética do motor em cruzeiro, que é em torno de $20 \%$ conforme 
indicado na Figura 10.4. Esta conclusão também é aplicada para a eficiência exergética da missão, que se aproxima da eficiência exergética do motor em cruzeiro quanto maior o tempo de missão.

Essa análise tem como objetivo verificar a tendência da eficiência do motor resultante de uma missão para outras categorias de avião. Obviamente a aeronave em questão possui limitações de alcance e tempo de missão e não poderia executar todas as missões estabelecidas na Figura 10.5. Entretanto, a análise é válida pois generaliza uma tendência do valor da eficiência exergética do motor e, conseqüentemente, da missão, para qualquer aeronave de transporte de passageiros de diferentes categorias.

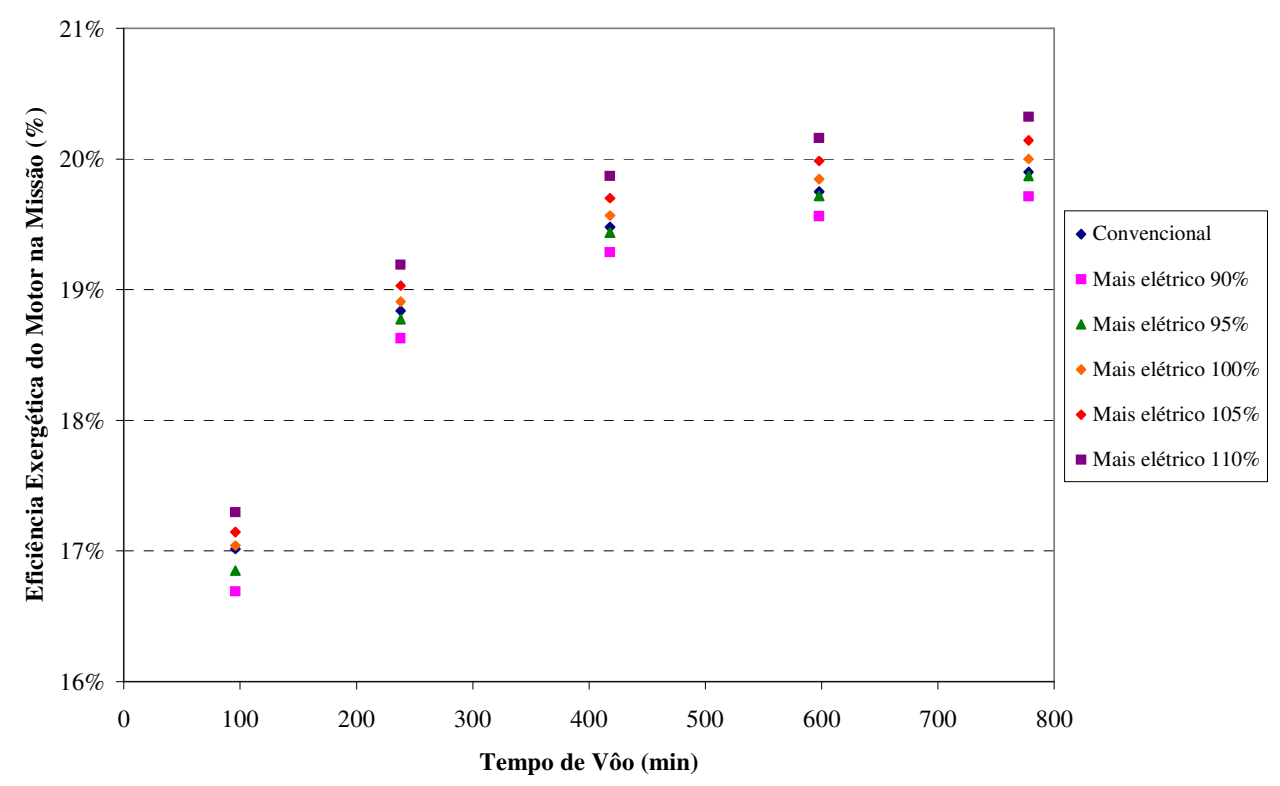

Figura 10.5: Variação da eficiência exergética do motor para diferentes missões.

Na mesma linha observada na figura anterior, a Figura 10.6 mostra a variação do consumo de combustível para os diferentes requisitos exergéticos de tração, ou de tração, e a tendência para diferentes missões. Há uma grande variação no consumo de combustível da missão quando se variam os requisitos de tração. Por outro lado, tem-se que a redução do consumo de combustível entre o avião com sistemas mais elétricos $100 \%$ (mesmo peso) e o com abordagem convencional é muito pequena, ficando em $0,10 \%$ para a missão mais curta e 0,25\% para a missão mais longa, valores estes obtidos apenas com as variações de extrações exergéticas dos sistemas observadas na Figura 10.1. Nota-se na mesma figura que, quanto maior o tempo de missão, menores são as diferenças de consumo de combustível entre as 
diferentes versões do avião com sistemas mais elétricos. Isto pode ser explicado pelo maior tempo de cruzeiro que tende a minimizar as diferenças de consumo de combustível das outras fases. A mesma Figura 10.6 também mostra a variação do consumo de combustível para o avião com sistemas convencionais sem extrações pneumáticas. Obviamente seria impossível concretizar o voo nas mesmas condições de velocidade e altitude sem nenhuma extração pneumática, entretanto, estes valores indicam o limite que um avião com sistemas mais elétricos poderia economizar em termos de combustível, que está em torno de 1,6\% para todas as missões.

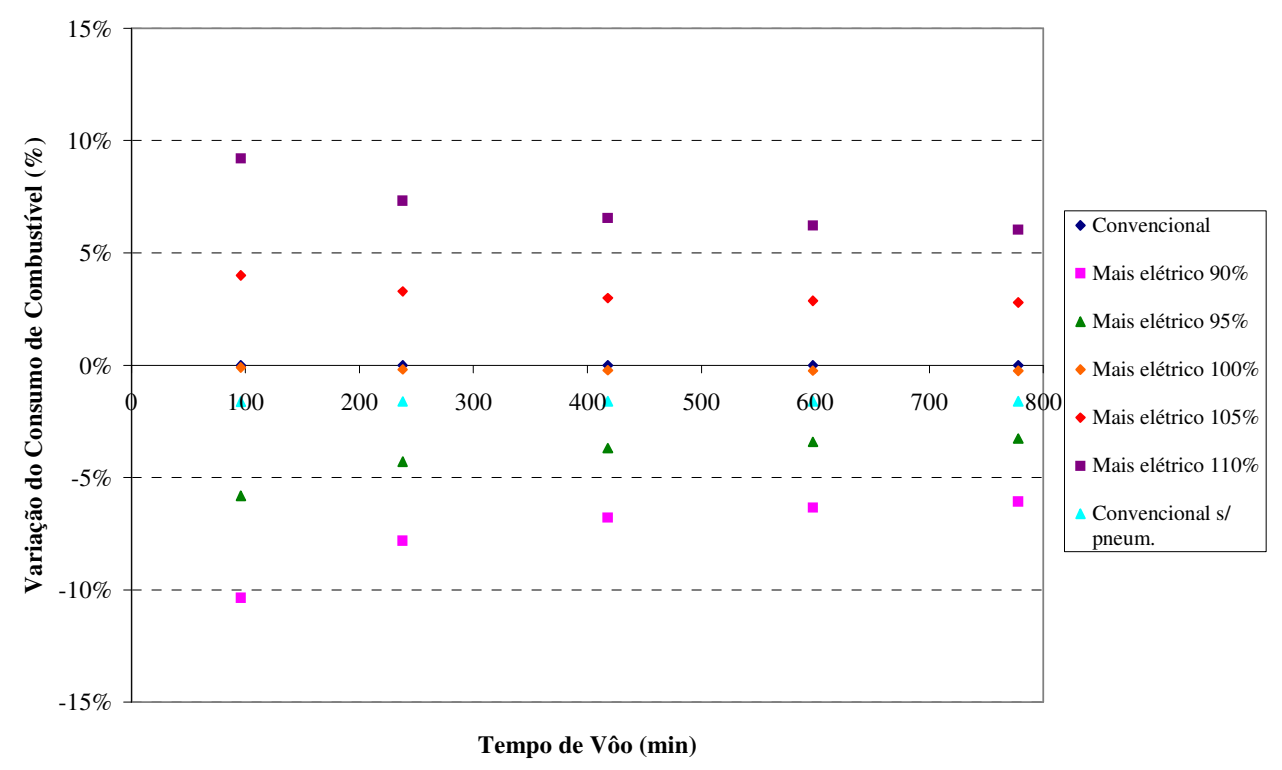

Figura 10.6: Variação do consumo de combustível do motor para diferentes missões.

10.1.3. Conclusões da análise de sensibilidade

A mudança de sistemas aeronáuticos convencionais por sistemas mais elétricos deve ser analisada em nível sistema e nível aeronave. A instalação de sistemas mais elétricos traz modificações no arrasto e no peso do avião que são refletidas por modificações nos requisitos de tração.

Os requisitos exergéticos de tração influenciam com mais intensidade a eficiência exergética da missão do que os requisitos de extrações exergéticas de sistemas. De um ponto de vista termodinâmico, a escolha por sistemas mais elétricos deve ser guiada pela variação 
dos requisitos de tração que esta aeronave possui com relação ao avião com sistemas convencionais. Ou seja, caso a versão mais elétrica apresente uma redução de peso de sistemas, a escolha pelos sistemas mais elétricos pode ficar mais evidente (GANDOLFI et al., 2009). 


\section{Conclusões e Recomendações}

O cenário mundial atual para aeronaves comerciais de transporte de passageiros possui uma forte tendência para redução de custos operacionais e, dentre eles, a redução do consumo de combustível. Este cenário é justificado pela variação dos preços dos combustíveis fósseis nos últimos anos e criação de novos regulamentos por parte dos governos para redução de emissões de poluentes atmosféricos. Diversas empresas fabricantes de aviões, fabricantes de sistemas e motores aeronáuticos, governos e institutos de pesquisa possuem projetos voltados nessa frente com o objetivo de redução do consumo de combustível, assim como redução da emissão de poluentes atmosféricos e redução de ruído externo à aeronave. Para tanto, algumas modificações nas aeronaves vem sendo implementadas como:

- Utilização em larga escala de materiais mais leves na fabricação da fuselagem, como materiais compósitos;

- Melhorias na aerodinâmica para redução do arrasto;

- Melhorias nos motores como a utilização de materiais mais leves (compósitos) na fabricação das pás do ventilador e entrada de ar, utilização de maiores razões de compressão com menos estágios, melhorias no sistema de combustão para tornar a combustão mais homogênea e reduzir as temperaturas na entrada da turbina, utilização de novos materiais e revestimentos nas pás das turbinas, melhorias na refrigeração das pás das turbinas, utilização de eixos contra-rotativos, aumento da taxa de derivação, utilização de caixa de engrenagens para reduzir a rotação do ventilador que é conectado ao eixo do compressor e turbina de baixa, inovações em manutenção, etc.;

- Utilização de sistemas com o conceito mais elétrico, ao eliminar a extração pneumática dos motores e substituir os sistemas convencionais por sistemas que utilizam potência elétrica, conforme já descrito anteriormente.

As modificações em sistemas são basicamente modificações nos processos de conversão de energia, que devem ser analisadas localmente (nível sistema) e também em nível avião. Para tanto, é necessário utilizar uma ferramenta de análise adequada, que compara numa mesma base todos os processos energéticos do avião. 
A análise exergética permite quantificar diferentes aspectos do projeto e desempenho de aeronaves em um mesmo padrão de avaliação e comparação. A análise compara todos os produtos úteis dos sistemas aeronáuticos como tração, potência pneumática, potência de eixo, potência elétrica, etc. numa mesma base. O uso combinado de índices aeronáuticos tradicionais, tais como combustível queimado, consumo específico de combustível e peso de decolagem, com parâmetros exergéticos de desempenho mostram-se de uso conveniente por permitirem uma análise global do desempenho da aeronave. Esta análise integrada permite a comparação de diferentes configurações de sistemas auxiliando o engenheiro no entendimento de como ocorrem e se relacionam os processos de conversão de energia na aeronave e no processo de otimização. Muitos trabalhos foram feitos nessa linha de pesquisa avaliando destruição de exergia e focando em redução da mesma (otimização), entretanto, nenhum trabalho apresenta um método que consolide os parâmetros já existentes e crie outros parâmetros comparativos entre sistemas. Este trabalho apresentou um método para tomada de decisões no projeto de sistemas aeronáuticos utilizando a análise exergética como principal ferramenta de análise, propondo assim o método harmonizador que faltava na literatura. Tal método pode ser aplicado em diferentes fases do desenvolvimento de aeronaves: desde os estudos conceituais e ante projeto até a definição conjunta que ocorre entre fabricantes de aeronaves e sistemas, em nível de componente, sistema e aeronave. Tomando como motivação a tendência mundial de tornar os aviões mais eficientes, utilizou-se o método exergético para investigar a substituição de sistemas convencionais por sistemas mais elétricos.

Este trabalho mostrou também um método para quantificação dos requisitos de dimensionamento do sistema de controle ambiental e do sistema de proteção contra gelo durante a fase de projeto conceitual de aeronaves, tanto para sistemas convencionais como para sistemas mais elétricos. Além disso, mostrou também uma abordagem de modelagem para sistemas convencionais e mais elétricos para o cálculo dos principais parâmetros termodinâmicos. Tais abordagens devem ser aplicadas para o levantamento das informações necessárias para o cálculo dos fluxos e taxas de exergia associados à aeronave.

Os principais índices propostos são: exergia destruída, rendimento exergético, consumo específico de exergia (CEE), exergia destruída na missão e eficiência exergética da missão. Propõe-se como exergia destruída a parcela devido às irreversibilidades associadas aos processos de conversão (termo de geração de entropia) somada aos fluxos exergéticos não 
utilizados e que deixam os sistemas. Por exemplo, a exergia associada aos gases de combustão que deixam o motor faz parte da exergia destruída, visto que a mesma não é utilizada de forma útil pela aeronave. O rendimento exergético proposto é a razão entre exergia útil que sai do sistema e exergia de entrada do sistema. O CEE mostra como a exergia associada ao combustível é utilizada em cada sistema, ou seja, evidencia quais sistemas impactam mais ou menos o consumo de combustível de uma aeronave e, conseqüentemente, a eficiência da mesma. A exergia total destruída ao longo da missão é obtida através de uma análise integral de todas as fases de vôo considerando todos os sistemas. Em seguida, pode-se calcular a eficiência exergética da missão utilizando a exergia total destruída ao longo da missão e as exergias totais relacionadas ao combustível e ao ar de admissão no motor.

O estudo comparativo das duas configurações de sistema de gerenciamento de ar evidenciou as vantagens de utilização da análise exergética do ponto de vista de qualidade dos processos de conversão de energia. A análise de um avião comercial mostrou que os sistemas de gerenciamento de ar (SEP, UCA e antigelo) são os maiores consumidores de exergia de uma aeronave com sistemas convencionais e que a substituição por sistemas mais elétricos é uma boa alternativa pois os sistemas mais elétricos são termodinamicamente mais eficientes:

- o SEP e o sistema de antigelo apresentam as maiores irreversibilidades dentre os sistemas convencionais, exceto motor;

- o compressor de cabine apresenta rendimentos exergéticos da ordem de $80 \%$ em todas as fases de voo, sendo que os rendimentos exergéticos do SEP variam entre $20 \%$ a $80 \%$, ficando em torno de $40 \%$ na fase de cruzeiro;

- o sistema de proteção contra gelo mais elétrico, baseado em painéis de aquecimento, apresentou maiores rendimentos exergéticos do que o sistema convencional.

Considerando a análise em que os aviões com sistemas convencionais e mais elétricos possuem o mesmo peso (mesmos requisitos de tração), a abordagem mais elétrica apresentou maiores rendimentos exergéticos de missão, com sistema de proteção contra gelo ligado e desligado, em torno de 0,5\% acima em ambas as missões. Este é um indicativo de que os sistemas mais elétricos podem contribuir para a melhoria da eficiência do avião.

Mostrou-se que o motor é a maior fonte de irreversibilidades em todas as fases de voo, tanto para o avião com sistemas convencionais como para o avião com sistemas mais 
elétricos. Isto ocorre pois o motor apresenta processos altamente irreversíveis como a combustão, mistura dos gases de combustão com ar de derivação e pela exergia física associada aos gases de escape, que é considerada exergia destruída. Devido à alta irreversibilidade do motor, o rendimento exergético da missão se aproxima ao rendimento exergético do motor, e isto mostra que os processos que ocorrem no mesmo influenciam a análise de forma muito mais intensa do que os processos que ocorrem em outros sistemas. Sendo assim, fez-se uma análise de sensibilidade do motor variando os requisitos exergéticos de tração, os quais são muito superiores aos requisitos exergéticos de extração para sistemas.

Naturalmente, o avião com sistemas mais elétricos possui diferença em peso e arrasto comparado ao avião com abordagem convencional de sistemas, que é refletida em diferença de tração. Mostrou-se que a variação dos requisitos exergéticos de tração, modifica a eficiência exergética do motor, e conseqüentemente da missão, com muito mais intensidade. Outras missões também foram analisadas e a mesma tendência foi observada. Quanto maior o tempo da missão, mais a eficiência exergética da mesma se aproxima à eficiência exergética do motor. Isto mostra que o aumento do tempo da missão só acentua os resultados e conclusões anteriores e mostra que os mesmos podem ser aplicados a qualquer categoria de avião comercial de transporte de passageiros ou carga.

Termodinamicamente o motor é o sistema que possui a maior influência na eficiência exergética do avião como um todo. Sendo assim, a busca por melhores taxas de consumo de combustível deve começar em melhorias associadas ao motor, que podem chegar a até $20 \%$ de redução de consumo de combustível segundo fabricantes de motor para a nova geração de motores. A substituição dos sistemas convencionais por sistemas mais elétricos pode levar a uma redução de consumo de combustível de no máximo 1,6\% no motor simulado, sendo este o valor de consumo de combustível que está relacionado às extrações pneumáticas do avião comercial analisado.

Usualmente, aeronaves militares possuem grandes requisitos de potência elétrica para alimentar os sistemas embarcados, como aviões de vigilância. Isto se deve ao fato das mesmas possuírem equipamentos como radares, computadores, equipamentos para comunicação, etc., que são essenciais para o cumprimento da missão. Com o aumento da potência elétrica consumida por sistemas, há o aumento dos requisitos de resfriamento dos equipamentos de cabine. Isto pode ser refletido em aumento da extração de potência pneumática, para acionar 
as máquinas de refrigeração de ciclo a ar, ou aumento da potência elétrica, para acionar máquinas de refrigeração por compressão de vapor. Quanto maior a extração de potência do motor pelos sistemas, mais importante torna-se a aplicação do método exergético para análise e otimização desses sistemas. O método proposto nesta tese aplica-se integralmente à aviação militar sendo os requisitos desse tipo de aeronaves específicos.

Algumas recomendações para trabalhos futuros:

- Realizar análise termoeconômica integral comparativa entre sistemas convencionais e mais elétricos, incluindo motor, para complementar os resultados já obtidos;

- Realizar análise exergética dos motores que possuem as melhorias propostas pelos fabricantes de motor;

- Realizar análise exergética para aeronaves militares e obter o desempenho exergético para tais sistemas;

- Criar método para análise exergética dos processos aerodinâmicos para otimização das superfícies de sustentação. 


\section{Bibliografia}

AL-KHALIL, K. M.; HORVATH, C.; MILLER, D. R.; WRIGHT, W. Validation of NASA thermal ice protection computer codes. Part 3 - validation of antice. Cleveland, $\mathrm{OH}$ : National Aeronautics and Space Agency, 2001. 18 p. (contractor report, 2001-210907).

ANDERSON, J. D. Aicraft Performance and Design. New York: MacGraw-Hill, 1999.

BEJAN, A. Advanced engineering thermodynamic. New York: John Wiley \& Sons, 1988.

BEJAN, A. Entropy generation through heat and fluid flow. New York: John Wiley \& Sons, 1982.

BEJAN, A., et al. Thermal design and optimization. New York: John Wiley \& Sons, 1996.

BEJAN, A., SIEMS, D. L. The need for exergy analysis and thermodynamic optmization in aircraft development. Exergy International Journal, v.1, p.14-24, 2001.

BEJAN, A.; TSATSARONIS, G.; MORAN, M. Thermal Design and Optimization., New York: John Wiley \& Sons, 1996, 542p.

BOEING, Current Market Outlook 2008-2027. 2008. Disponível em: http://www.boeing.com/commercial/cmo/. Acessado em: 20 de Março de 2008.

BRASIL. Agência Nacional de Aviação Civil (ANAC). RBAC 25 - Requisitos de Aeronavegabilidade: Aviões Categoria Transporte. 2009. Disponível em: http://www.anac.gov.br/arquivos/pdf/RBAC\%2025\%20Emenda\%20128.pdf. Acessado em: 23 de Abril de 2010.

BREWER, K. M. Exergy Methods for the Mission Level Analysis and Optimization of Generic Hypersonic Vehicles. Master Dissertation, Faculty of Virginia Polytechnic Institute and State University, Blacksburg, VA, 2006.

BUTT, J. R. A Study of Morphing Wing Effectiveness in Fighter Aircraft using Exergy Analysis and Global Optimization Techniques. Master Dissertation, Faculty of Virginia Polytechnic Institute and State University, Blacksburg, VA, 2005.

CONCEIÇÃO, S.T.; ZAPAROLI, E.L.; TURCIO, W.H.L. Thermodynamic Study of Aircraft Air Cycle Machine: 3-wheel x 4-wheel, 16th SAE Brasil International Mobility Technology Congress and Exposition, São Paulo, Brazil, 28-30 Novembro, 2007. 
EBELING, A. Fundamentals of aircraft environmental control. Hyden Book Company, 1968.

ESTADOS UNIDOS DA AMÉRICA. Federal Aviation Administration (FAA). Part 25 - Airworthiness Standards: Transport Category Airplanes. 2010. Disponível em: http://ecfr.gpoaccess.gov/cgi/t/text/text-

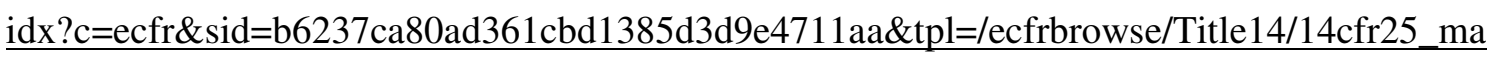
in_02.tpl. Acessado em: 23 de Abril de 2010.

ETELE, J.; ROSEN, A. R. Sensitivity of exergy efficiencies of aerospace engines to reference environment selection. Exergy International Journal, v.1, p.91-99, 2001.

EUROPA. European Aviation Safety Agency (EASA). Jar 25 - Large Aeroplanes. Disponível em: http://www.jaa.nl/publications/jars/JAR\%2025.pdf. 2007. Acessado em: 23 de Abril de 2010.

EUROPA. Advisory Council for Aeronautics Research in Europe (ACARE). European Aeronautics: A Vision For 2020. Disponível em: http://www.acare4europe.com/docs/vision\%202020.pdf. 2001. Acessado em: 23 de Abril de 2010.

FALEIRO, L. Summary Of The European Power Optimized Aircraft (PAO) Project. 25th International Congress Of The Aeronautical Sciences, 2006.

FIGLIOLA, R. S.; TIPTON, R.; LI, H. Exergy Approach to Decision-Based Design of Integrated Aircraft Thermal Systems. Journal of Aircraft, Vol. 40, №1, pp. 49-55, JanuaryFebruary 2003.

GANDOLFI, R., Simulação de um Sistema Integrado de Potência Pneumática para uma Aeronave Corporativa. Dissertação de mestrado - Instituto Tecnológico de Aeronáutica, São José dos Campos, 2004.

GANDOLFI, R.; PELLEGRINI, L.F.; SILVA, G.A.L; OLIVEIRA JR. S. Aircraft Air Management Systems Trade-Off Study Using Exergy Analysis As A Design Comparison Tool. Proceedings of COBEM 2007, 19th International Congress of Mechanical Engineering, Brasília, Brasil, Novembro 5-9, 2007;

GANDOLFI R.; PELLEGRINI, L.F.; SILVA, G.A.L; OLIVEIRA JR., S. Exergy Analysis Applied To A Complete Flight Mission Of A Commercial Aircraft. In Proceedings of $46^{\text {th }}$ AIAA, Reno, United States, Janeiro 7-10, 2008 (in CD-ROM).

GANDOLFI, R.; PELlEGRINI, L.F.; SALVADOR, P.; OLIVEIRA JR., S., More Electric Engine Modeling And Analysis Using Exergy As A Design Comparison Tool. Proceedings of 22nd International Conference on Efficiency, Cost, Optimization, Simulation 
and Environmental Impact of Energy Systems (ECOS), Foz do Iguaçu, Brazil, Agosto 31Setembro 3, 2009 (in CD-ROM).

GANDOLFI, R.; PELlEGRINI, L.F.; OLIVEIRA JR., S., More Electric Aircraft Analysis Using Exergy as a Design Comparison Tool. In Proceedings of $48^{\text {th }}$ AIAA, Orlando, United States, Janeiro 4-7, 2010 (in CD-ROM).

GOGUS, Y.A.; et al. Exergy Balance of a General System With Variation of Environmental Conditions and Some Applications. Energy, v.27, p.625-646, 2002.

GORAJ, Z. An overview of the deicing and anti-icing technologies with prospects for the future. 24th International Congress of the Aeronautical Sciences (ICAS), 2004.

HUNEKE, K. Jet Engines: Fundamentals of Theory, Design and Operation. USA, Motorbooks International Publishers \& Wholesalers, 1997.

INTERNATIONAL ORGANIZATION FOR STANDARDIZATION Standard Atmosphere. ISO 2533:1975, 1975.

INCROPERA, F.P. Fundamentals of Heat and Mass Transfer. Singapore: John Wiley \& Sons, 1990.

KLEIN, S. A. Engineering Equation Solver (EES). F-Chart Software, 2007.

KOTAS, T. J. The Exergy Method of Thermal Plant Analysis., London: Butterworths, 1985.

MARKELL, K. C. Exergy Methods for the Generic Analysis and Optimization of Hypersonic Vehicle Concepts. Master Dissertation, Faculty of Virginia Polytechnic Institute and State University, Blacksburg, VA, 2005.

MIZIOKA, L. S. Modelagem e Análise de Desempenho do Servo Atuador do Sistema de Leme de uma Aeronave sob Variação de Temperatura. Dissertação de mestrado na Área de Sistemas Aeroespaciais e Mecatrônica, Instituto Tecnológico de Aeronáutica, São José dos Campos, 2009.

MOORHOUSE, D. J. The vision and need for energy-based design methods. In: $8^{\text {th }}$ AIAA/USAF/NASA/ISSMO Symposium On Multidisciplinary Analysis And Optimization, Long Beach, 2000.

MOORHOUSE, D. J. Proposed System-Level Multidisciplinary Analysis Technique Based on Exergy Methods. Journal of Aircraft, Vol. 40, No. 1, Jan-Feb 2003, pp. 11-15.

MORAN, M. J. Availability analysis: a guide to efficient energy use. Englewood Cliffs: Prentice-Hall, 1982.

MORAN, M. J.; SHAPIRO, H. N., 1996, Fundamentals of Engineering Thermodynamics, John Wiley \& Sons, Inc. 
MUÑOZ, J. D. Optimization Strategies for the Synthesis/Design of Highly Coupled, Highly Dynamic Energy Systems. Ph.D Dissertation, Faculty of Virginia Polytechnic Institute and State University, Blacksburg, VA, 2000.

MUSSI, C.E.T. Estudo de uma Servoválvula Eletro-Hidráulica para Aplicação de Métodos de Detecção e Isolamento de Falhas. Tese (Mestrado em Engenharia Aeronáutica e Mecânica), Instituto Tecnológico de Aeronáutica, São José dos Campos, 2008.

NEWMAN, R. The More Electric Engine Concept. World Aviation Congress \& Exposition, Reno, NV, USA, November 2004.

NRL, Gas Turbine Simulation Program For Windows. Version 10.0.2.7, 2005, Disponível em: http://www.gspteam.com/. Acessado em: 24 de Abril de 2010.

ORDONEZ, J.C.; BEJAN, A. Minimum Power Requirement for Environmental Control of Aircraft. Energy, Vol. 28, 2003, pp. 1183-1202.

PAULUS, D.; GAGGIOLI, R. Rational Objective Functions for Vehicles. AIAA Paper No. 2000-4852, 8th AIAA/USAF/NASA/ISSMO Symposium on Multidisciplinary Analysis and Optimization, Long Beach, California, September 6-8, 2000, pp. 1-11.

PELLEGRINI, L.F.; GANDOLFI, R.; SILVA, G.A.L; OLIVEIRA, Jr. S. Exergy Analysis As A Tool For Decision Making In Aircraft Systems Design. In Proceedings of $45^{\text {th }}$ AIAA, Reno, United States, January 8-11, 2007 (in CD-ROM).

PERIANNAN, V. Investigation of the Effects of Various Energy and Exergy-Based Objectives/Figures of Merit on the Optimal Design of High Performance Aircraft System. Master Dissertation, Faculty of Virginia Polytechnic Institute and State University, Blacksburg, VA, 2005.

RANCRUEL, D. F. A Decomposition Strategy Based on Thermoeconomic Isolation Applied to the Optimal Synthesis/Design and Operation of an Advanced Fighter Aircraft System. Master Dissertation, Faculty of Virginia Polytechnic Institute and State University, Blacksburg, VA, 2002.

ROTH, B. A Theoretical Treatment of Technical Risk in Modern Propulsion System Design. Ph.D Dissertation, Georgia Institute of Technology, Atlanta, GA, 2000.

ROTH, B. The Role of Thermodynamic Work Potential in Aerospace Vehicle Design. ISABE-2003-1199, XVI International Symposium on Air Breathing Engines (ISABE), Cleveland, 31 Aug - 5 Sep, 2003.

SAE, Aerothermodynamic Systems Engineering and Design - AIR 1168/3. USA: SAE, 1990a.

SAE, Ice, Rain, Fog, and Frost Protection - AIR 1168/4. USA: SAE, $1990 \mathrm{~b}$. 
SAE, Aerospace Pressurization System Design - AIR 1168/7. USA: SAE, 1991.

STOECKER, W. F. Design of thermal systems. McGraw-Hill, 1989.

SZARGUT, J.; MORRIS, D. R.; STEWARD, F. R. Exergy Analysis of Thermal, Chemical, and Metallurgical Processes. New York, Hemisphere 1988, 332p.

TONA, C.; Raviolo, P. A.; Pellegrini, L. P.; OLIVEIRA JR. S. Exergy and thermoeconomic analysis of a turbofan engine during a typical commercial flight. Energy, v.35, p.952-959, 2010.

TSATSARONIS, G. Thermoeconomic Analysis and Optimization of Energy Systems. Energy, v. 19, n. 3, p. 227-257, 1993.

TURGUT, E. T.; KARAKOC, T. H.; HEPBASLI, A. Exergetic analysis of an aircraft turbofan engine. International Journal Of Energy Research, John Wiley \& Sons, Ltd., 2007.

VARGAS, J. V. C., BEJAN, A. Integrative Thermodynamic Optimization of the Environmental Control System of an Aircraft. International Journal of Heat and Mass Transfer, Vol. 44, 2001, pp. 3907-3917.

WYLEN, G. J. V., SONNTAG, R. E. Fundamentos da termodinâmica clássica. São Paulo: Edgard Blucher, 1993.

YUAN, X. A mathematical model on the thermal behaviour on aircraft cabin. 1982. 102p.Tese (doutorado) - Faculdade de ciências mecânicas, RWTH (Rheinisch-Westfälischen Technischen Hochachule). Aachen. 


\section{Apêndice A. Taxas de exergia relacionadas ao avião com sistemas convencionais}

Tabela A.1: Taxas de exergia do motor, SEP e sistema elétrico do avião com sistemas convencionais (sistema de antigelo desligado).

\begin{tabular}{|c|c|c|c|c|c|c|c|c|}
\hline \multirow{2}{*}{ Fase de Voo } & \multirow{2}{*}{$\begin{array}{c}\text { Altitude } \\
{[\mathrm{m}]}\end{array}$} & \multicolumn{3}{|c|}{ Motor $[k W]$} & \multicolumn{3}{|c|}{ SEP [kW] } & \multirow{2}{*}{$\frac{\text { Sistema Elétrico [kW] }}{\dot{W}_{\text {Elétrico }}}$} \\
\hline & & $\dot{B}_{\text {Tração }}$ & $\dot{B}_{C o m b}$ & $\dot{B}_{A r}$ & $\dot{B}_{S E P, V e n t}$ & $\dot{B}_{S E P, C o m p}$ & $\dot{W}_{S E P}$ & \\
\hline 1 - Decolagem & 0 & 1973,00 & 15935,00 & 824,80 & 74,49 & 62,80 & 1,75 & 10,00 \\
\hline 2 - Subida & 6096 & 2056,00 & 9879,00 & 2014,00 & 38,40 & 38,12 & 1,75 & 10,00 \\
\hline 3 - Subida & 10668 & 1511,00 & 6143,00 & 1738,00 & 42,40 & 49,23 & 1,75 & 10,00 \\
\hline 4 - Cruzeiro & 11277,6 & 1509,00 & 5915,00 & 1839,00 & 42,64 & 50,62 & 1,75 & 10,00 \\
\hline 5 - Cruzeiro & 12496,8 & 1238,00 & 4878,00 & 1528,00 & 38,84 & 47,64 & 1,75 & 10,00 \\
\hline 6 - Descida & 10668 & 511,90 & 2704,00 & 1802,00 & 4,62 & 44,59 & 1,75 & 10,00 \\
\hline 7 - Descida & 6096 & 471,30 & 3021,00 & 1802,00 & 3,54 & 32,23 & 1,75 & 10,00 \\
\hline 8 - Espera & 4572 & 1718,00 & 10505,00 & 1423,00 & 35,61 & 40,23 & 1,75 & 10,00 \\
\hline $\begin{array}{l}9 \text { - Aproximação e } \\
\text { aterrissagem }\end{array}$ & 0 & 283,20 & 2934,00 & 527,90 & 0,01 & 35,44 & 1,75 & 10,00 \\
\hline
\end{tabular}

Tabela A.2: Taxas de exergia do sistema hidráulico, UCA e cabine do avião com sistemas convencionais (sistema de antigelo desligado).

\begin{tabular}{|c|c|c|c|c|c|c|c|c|c|}
\hline \multirow{2}{*}{ Fase de Voo } & \multirow{2}{*}{$\begin{array}{l}\text { Altitude } \\
\text { [m] }\end{array}$} & \multicolumn{2}{|c|}{ Sistema Hidráulico [kW] } & \multicolumn{3}{|c|}{$\mathrm{UCA}[\mathbf{k W}]$} & \multicolumn{3}{|c|}{ Cabine [kW] } \\
\hline & & $\dot{W}_{\text {Mec, Hidráulico }}$ & $\dot{W}_{\text {Hidráulico }}$ & $\dot{B}_{U C A, e}$ & $\dot{W}_{U C A}$ & $\dot{B}_{T C, e}$ & $\dot{B}_{U C A, s}$ & $\dot{W}_{\text {Cabine }}$ & $\dot{B}_{Q, \text { Cabine }}$ \\
\hline 1 - Decolagem & 0 & 5,00 & 1,75 & 33,14 & 1,75 & 4,15 & 3,43 & 3,00 & 0,19 \\
\hline 2 - Subida & 6096 & 5,00 & 1,75 & 24,37 & 1,75 & 6,64 & 6,63 & 3,00 & 0,50 \\
\hline 3 - Subida & 10668 & 5,00 & 1,75 & 38,99 & 1,75 & 12,33 & 14,25 & 3,00 & 0,23 \\
\hline 4 - Cruzeiro & 11277,6 & 5,00 & 1,75 & 40,16 & 1,75 & 13,92 & 14,66 & 3,00 & 0,31 \\
\hline 5 - Cruzeiro & 12496,8 & 5,00 & 1,75 & 40,19 & 1,75 & 13,06 & 15,47 & 3,00 & 0,31 \\
\hline 6 - Descida & 10668 & 5,00 & 1,75 & 35,99 & 1,75 & 10,04 & 11,11 & 3,00 & 0,35 \\
\hline 7 - Descida & 6096 & 5,00 & 1,75 & 24,26 & 1,75 & 9,05 & 5,99 & 3,00 & 0,50 \\
\hline 8 - Espera & 4572 & 5,00 & 1,75 & 27,62 & 1,75 & 5,21 & 7,14 & 3,00 & 0,49 \\
\hline $\begin{array}{c}9 \text { - Aproximação e } \\
\text { aterrissagem }\end{array}$ & 0 & 5.00 & 1.75 & 31.19 & 1.75 & 6.15 & 4.25 & 3.00 & 0.19 \\
\hline
\end{tabular}


Tabela A.3: Taxas de exergia do motor, SEP e sistemas elétrico do avião com sistemas convencionais (sistema de antigelo ligado).

\begin{tabular}{|c|c|c|c|c|c|c|c|c|}
\hline \multirow{2}{*}{ Fase de Voo } & \multirow{2}{*}{$\begin{array}{c}\text { Altitude } \\
\text { [m] }\end{array}$} & \multicolumn{3}{|c|}{ Motor [kW] } & \multicolumn{3}{|c|}{ SEP [kW] } & \multirow{2}{*}{$\frac{\text { Sistema Elétrico [kW] }}{\dot{W}_{\text {Elétrico }}}$} \\
\hline & & $\dot{B}_{\text {Tração }}$ & $\dot{B}_{C o m b}$ & $\dot{B}_{A r}$ & $\dot{B}_{S E P, V e n t}$ & $\dot{B}_{S E P, C o m p}$ & $\dot{W}_{S E P}$ & \\
\hline 1 - Decolagem & 0 & 1973,00 & 16260,00 & 830,40 & 248,30 & 175,30 & 1,75 & 10,00 \\
\hline 2 - Subida & 6096 & 2056,00 & 10276,00 & 2035,00 & 177,90 & 144,10 & 1,75 & 10,00 \\
\hline 3 - Subida & 10668 & 1511,00 & 6143,00 & 1738,00 & 42,40 & 49,23 & 1,75 & 10,00 \\
\hline 4 - Cruzeiro & 11277,6 & 1509,00 & 5915,00 & 1839,00 & 42,64 & 50,62 & 1,75 & 10,00 \\
\hline 5 - Cruzeiro & 12496,8 & 1238,00 & 4878,00 & 1528,00 & 38,84 & 47,64 & 1,75 & 10,00 \\
\hline 6 - Descida & 10668 & 511,90 & 2704,00 & 1802,00 & 4,62 & 44,59 & 1,75 & 10,00 \\
\hline 7 - Descida & 6096 & 471,30 & 3071,00 & 1806,00 & 34,18 & 117,60 & 1,75 & 10,00 \\
\hline 8 - Espera & 4572 & 1718,00 & 10825,00 & 1437,00 & 205,00 & 202,90 & 1,75 & 10,00 \\
\hline $\begin{array}{l}9 \text { - Aproximação e } \\
\text { aterrissagem }\end{array}$ & 0 & 283,20 & 3060,00 & 527,50 & 0,02 & 106,20 & 1,75 & 10,00 \\
\hline
\end{tabular}

Tabela A.4: Taxas de exergia do sistema hidráulico, UCA e cabine do avião com sistemas convencionais (sistema de antigelo ligado).

\begin{tabular}{|c|c|c|c|c|c|c|c|c|c|}
\hline \multirow{2}{*}{ Fase de Voo } & \multirow{2}{*}{$\begin{array}{c}\text { Altitude } \\
{[\mathrm{m}]}\end{array}$} & \multicolumn{2}{|c|}{ Sistema Hidráulico [kW] } & \multicolumn{3}{|c|}{ UCA $[\mathbf{k W}]$} & \multicolumn{3}{|c|}{ Cabine $[k W]$} \\
\hline & & $\dot{W}_{\text {Mec,Hidráulico }}$ & $\dot{W}_{\text {Hidráulico }}$ & $\dot{B}_{U C A, e}$ & $\dot{W}_{U C A}$ & $\dot{B}_{T C, e}$ & $\dot{B}_{U C A, s}$ & $\dot{W}_{\text {Cabine }}$ & $\dot{B}_{Q, \text { Cabine }}$ \\
\hline 1 - Decolagem & 0 & 5,00 & 1,75 & 33,14 & 1,75 & 4,15 & 3,43 & 3,00 & 0,19 \\
\hline 2 - Subida & 6096 & 5,00 & 1,75 & 24,37 & 1,75 & 6,64 & 6,63 & 3,00 & 0,50 \\
\hline 3 - Subida & 10668 & 5,00 & 1,75 & 38,99 & 1,75 & 12,33 & 14,25 & 3,00 & 0,23 \\
\hline 4 - Cruzeiro & 11277,6 & 5,00 & 1,75 & 40,16 & 1,75 & 13,92 & 14,66 & 3,00 & 0,31 \\
\hline 5 - Cruzeiro & 12496,8 & 5,00 & 1,75 & 40,19 & 1,75 & 13,06 & 15,47 & 3,00 & 0,31 \\
\hline 6 - Descida & 10668 & 5,00 & 1,75 & 35,99 & 1,75 & 10,04 & 11,11 & 3,00 & 0,35 \\
\hline 7 - Descida & 6096 & 5,00 & 1,75 & 24,26 & 1,75 & 9,05 & 5,99 & 3,00 & 0,50 \\
\hline 8 - Espera & 4572 & 5,00 & 1,75 & 27,62 & 1,75 & 5,21 & 7,14 & 3,00 & 0,49 \\
\hline $\begin{array}{l}9 \text { - Aproximação e } \\
\text { aterrissagem }\end{array}$ & 0 & 5,00 & 1,75 & 32,77 & 1,75 & 6,15 & 4,25 & 3,00 & 0,19 \\
\hline
\end{tabular}


Tabela A.5: Taxas de exergia do sistema de antigelo convencional.

\begin{tabular}{|c|c|c|c|c|c|c|c|c|c|c|}
\hline \multirow{2}{*}{ Fase de Voo } & \multirow{2}{*}{$\begin{array}{c}\text { Altitude } \\
{[\mathbf{m}]}\end{array}$} & \multicolumn{3}{|c|}{ Antigelo do Motor [kW] } & \multicolumn{3}{|c|}{ Antigelo da Asa [kW] } & \multicolumn{3}{|c|}{ Antigelo do Estabilizador [kW] } \\
\hline & & $\dot{B}_{\text {Antigelo,e }}$ & $\dot{W}_{\text {Antigelo }}$ & $\dot{B}_{Q, B_{\text {Bordas_de_Ataque }}}$ & $\dot{B}_{\text {Antigelo }, e}$ & $\dot{W}_{\text {Antigelo }}$ & $\dot{B}_{Q, B_{0} d a s_{-} d e \_ \text {Ataque }}$ & $\dot{B}_{\text {Antigelo }, e}$ & $\dot{W}_{\text {Antigelo }}$ & $\dot{B}_{Q, B o r d a s_{-} d e \_A t a q u e}$ \\
\hline 1 - Decolagem & 0 & 12,99 & 0,58 & 2,71 & 39,12 & 0,58 & 7,82 & 11,52 & 0,58 & 2,31 \\
\hline 2 - Subida & 6096 & 16,48 & 0,58 & 4,00 & 50,49 & 0,58 & 11,80 & 14,87 & 0,58 & 3,48 \\
\hline 3 - Subida & 10668 & 0,00 & 0,58 & 0,00 & 0,00 & 0,58 & 0,00 & 0,00 & 0,58 & 0,00 \\
\hline 4 - Cruzeiro & 11277,6 & 0,00 & 0,58 & 0,00 & 0,00 & 0,58 & 0,00 & 0,00 & 0,58 & 0,00 \\
\hline 5 - Cruzeiro & 12496,8 & 0,00 & 0,58 & 0,00 & 0,00 & 0,58 & 0,00 & 0,00 & 0,58 & 0,00 \\
\hline 6 - Descida & 10668 & 0,00 & 0,58 & 0,00 & 0,00 & 0,58 & 0,00 & 0,00 & 0,58 & 0,00 \\
\hline 7 - Descida & 6096 & 16,61 & 0,58 & 3,87 & 51,00 & 0,58 & 11,39 & 15,02 & 0,58 & 3,36 \\
\hline 8 - Espera & 4572 & 16,08 & 0,58 & 3,86 & 49,17 & 0,58 & 11,35 & 14,48 & 0,58 & 3,35 \\
\hline $\begin{array}{l}9 \text { - Aproximação e } \\
\text { aterrissagem }\end{array}$ & 0 & 13,34 & 0,58 & 2,71 & 40,33 & 0,58 & 7,82 & 11,88 & 0,58 & 2,31 \\
\hline
\end{tabular}




\section{Apêndice B. Taxas de exergia relacionadas ao avião com sistemas mais elétricos $100 \%$ (mesmo peso)}

Tabela B.1: Taxas de exergia do motor, compressor de cabine e sistema elétrico do avião com sistemas mais elétricos (sistema de degelo desligado).

\begin{tabular}{|c|c|c|c|c|c|c|c|}
\hline \multirow{2}{*}{ Fase de Voo } & \multirow{2}{*}{ Altitude [m] } & \multicolumn{3}{|c|}{ Motor $[\mathrm{kW}]$} & \multicolumn{2}{|c|}{ Compressor de Cabine [kW] } & \multirow{2}{*}{$\frac{\text { Sistema Elétrico [kW] }}{\dot{W}_{\text {Elétrico }}}$} \\
\hline & & $\dot{B}_{\text {Trą̧ão }}$ & $\dot{B}_{\text {Comb }}$ & $\dot{B}_{A r}$ & $\dot{B}_{A r, e}$ & $\dot{W}_{\text {compressor }}$ & \\
\hline 1 - Decolagem & 0 & 1973,00 & 15908,00 & 882,20 & 1,61 & 32,01 & 40,70 \\
\hline 2 - Subida & 6096 & 2056,00 & 9852,00 & 2067,00 & 3,57 & 22,93 & 31,34 \\
\hline 4 - Cruzeiro & 11277,6 & 1509,00 & 5897,00 & 1876,00 & 7,39 & 38,89 & 47,78 \\
\hline 5 - Cruzeiro & 12496,8 & 1238,00 & 4864,00 & 1554,00 & 7,07 & 41,47 & 50,44 \\
\hline 6 - Descida & 10668 & 511,90 & 3083,00 & 1730,00 & 6,84 & 35,65 & 44,45 \\
\hline $\begin{array}{l}9 \text { - Aproximação e } \\
\text { aterrissagem }\end{array}$ & 0 & 283,20 & 2934,00 & 571,20 & 1,77 & 32,01 & 40,70 \\
\hline
\end{tabular}

Tabela B.2: Taxas de exergia do sistema hidráulico, UCA e cabine do avião com sistemas mais elétricos (sistema de degelo desligado).

\begin{tabular}{|c|c|c|c|c|c|c|c|c|c|}
\hline \multirow{2}{*}{ Fase de Voo } & \multirow{2}{*}{$\begin{array}{c}\text { Altitude } \\
\text { [m] }\end{array}$} & \multicolumn{2}{|c|}{ Sistema Hidráulico [kW] } & \multicolumn{3}{|c|}{ UCA $[\mathrm{kW}]$} & \multicolumn{3}{|c|}{ Cabine $[\mathrm{kW}]$} \\
\hline & & $\dot{W}_{\text {Mec,Hidráulico }}$ & $\dot{W}_{\text {Hidráulico }}$ & $\dot{B}_{U C A, e}$ & $\dot{W}_{U C A}$ & $\dot{B}_{T C, e}$ & $\dot{B}_{U C A, s}$ & $\dot{W}_{\text {Cabine }}$ & $\dot{B}_{Q, \text { Cabine }}$ \\
\hline 1 - Decolagem & 0 & 5,00 & 1,75 & 27,50 & 1,75 & 3,22 & 2,87 & 3,00 & 0,19 \\
\hline 3 - Subida & 10668 & 5,00 & 1,75 & 34,36 & 1,75 & 13,12 & 14,59 & 3,00 & 0,23 \\
\hline 4 - Cruzeiro & 11277,6 & 5,00 & 1,75 & 35,82 & 1,75 & 14,78 & 15,13 & 3,00 & 0,30 \\
\hline 5 - Cruzeiro & 12496,8 & 5,00 & 1,75 & 38,19 & 1,75 & 14,13 & 16,04 & 3,00 & 0,31 \\
\hline 6 - Descida & 10668 & 5,00 & 1,75 & 32,75 & 1,75 & 13,69 & 13,00 & 3,00 & 0,35 \\
\hline $\begin{array}{c}9 \text { - Aproximação e } \\
\text { aterrissagem }\end{array}$ & 0 & 5,00 & 1,75 & 27,50 & 1,75 & 3,53 & 2,87 & 3,00 & 0,19 \\
\hline
\end{tabular}


Tabela B.3: Taxas de exergia do motor, compressor de cabine e sistema elétrico do avião com sistemas mais elétricos (sistema de degelo ligado).

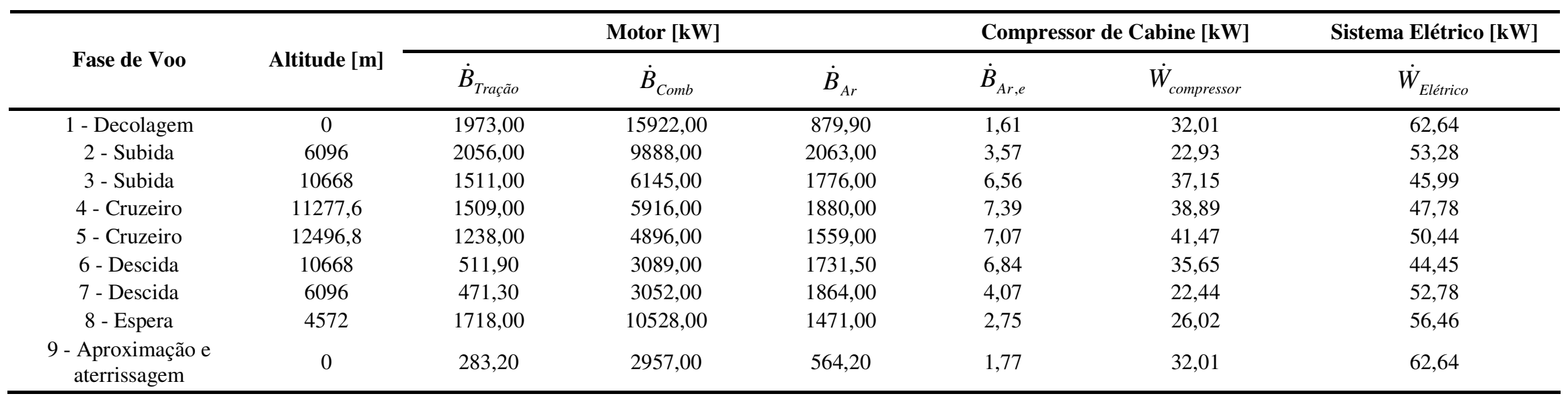

Tabela B.4: Taxas de exergia do sistema hidráulico, UCA e cabine do avião com sistemas mais elétricos (sistema de degelo ligado).

\begin{tabular}{|c|c|c|c|c|c|c|c|c|c|}
\hline \multirow{2}{*}{ Fase de Voo } & \multirow{2}{*}{$\begin{array}{c}\text { Altitude } \\
\text { [m] }\end{array}$} & \multicolumn{2}{|c|}{ Sistema Hidráulico [kW] } & \multicolumn{3}{|c|}{ UCA $[\mathbf{k W}]$} & \multicolumn{3}{|c|}{ Cabine $[k W]$} \\
\hline & & $\dot{W}_{\text {Mec,Hidráulico }}$ & $\dot{W}_{\text {Hidráulico }}$ & $\dot{B}_{U C A, e}$ & $\dot{W}_{U C A}$ & $\dot{B}_{T C, e}$ & $\dot{B}_{U C A, s}$ & $\dot{W}_{\text {Cabine }}$ & $\dot{B}_{Q, \text { Cabine }}$ \\
\hline 1 - Decolagem & 0 & 5,00 & 1,75 & 27,50 & 1,75 & 3,22 & 2,87 & 3,00 & 0,19 \\
\hline 2 - Subida & 6096 & 5,00 & 1,75 & 20,52 & 1,75 & 7,14 & 6,87 & 3,00 & 0,50 \\
\hline 3 - Subida & 10668 & 5,00 & 1,75 & 34,36 & 1,75 & 13,12 & 14,59 & 3,00 & 0,23 \\
\hline 4 - Cruzeiro & 11277,6 & 5,00 & 1,75 & 35,82 & 1,75 & 14,78 & 15,13 & 3,00 & 0,30 \\
\hline 5 - Cruzeiro & 12496,8 & 5,00 & 1,75 & 38,19 & 1,75 & 14,13 & 16,04 & 3,00 & 0,31 \\
\hline 6 - Descida & 10668 & 5,00 & 1,75 & 32,75 & 1,75 & 13,69 & 13,00 & 3,00 & 0,35 \\
\hline 7 - Descida & 6096 & 5,00 & 1,75 & 20,01 & 1,75 & 8,13 & 5,54 & 3,00 & 0,50 \\
\hline 8 - Espera & 4572 & 5,00 & 1,75 & 23,20 & 1,75 & 5,50 & 7,34 & 3,00 & 0,49 \\
\hline $\begin{array}{l}9 \text { - Aproximação e } \\
\text { aterrissagem }\end{array}$ & 0 & 5,00 & 1,75 & 27,50 & 1,75 & 3,53 & 2,87 & 3,00 & 0,19 \\
\hline
\end{tabular}


Tabela B.5: Taxas de exergia do sistema de degelo mais elétrico.

\begin{tabular}{|c|c|c|c|c|c|c|c|c|}
\hline Fase de Voo & Altitude [m] & \multicolumn{3}{|c|}{ Antigelo do Motor [kW] } & \multicolumn{2}{|c|}{ Degelo da Asa [kW] } & \multicolumn{2}{|c|}{ Degelo do Estabilizador [kW] } \\
\hline 2 - Subida & 6096 & 16,48 & 0,58 & 4,00 & 15,60 & 4,46 & 6,70 & 1,83 \\
\hline 3 - Subida & 10668 & 0,00 & 0,58 & 0,00 & 0,50 & 0,00 & 0,50 & 0,00 \\
\hline 4 - Cruzeiro & 11277,6 & 0,00 & 0,58 & 0,00 & 0,50 & 0,00 & 0,50 & 0,00 \\
\hline 5 - Cruzeiro & 12496,8 & 0,00 & 0,58 & 0,00 & 0,50 & 0,00 & 0,50 & 0,00 \\
\hline 8 - Espera & 4572 & 16,08 & 0,58 & 3,86 & 15,60 & 4,34 & 6,70 & 1,78 \\
\hline $\begin{array}{l}9 \text { - Aproximação e } \\
\text { aterrissagem }\end{array}$ & 0 & 13,34 & 0,58 & 2,71 & 15,60 & 3,35 & 6,70 & 1,38 \\
\hline
\end{tabular}




\section{Apêndice C. Modelagem do ponto de projeto do motor}

Para definir o ponto de projeto do motor, é necessário definir os parâmetros referentes aos pontos de projeto de cada componente. Utilizaram-se os mesmos parâmetros e mapas dos componentes para definir o motor convencional e o motor mais elétrico.

Coletor dinâmico: no objeto coletor é preciso definir o fluxo de ar de entrada e a especificação de perda de carga na forma de relação de compressão. A relação de compressão é razão entre a pressão total na saída do coletor dividida pela pressão total na entrada do coletor. Caso seja de interesse realizar o cálculo das condições estáticas do fluxo, é preciso definir também as áreas de entrada e de saída conforme especificado na Figura C.1.

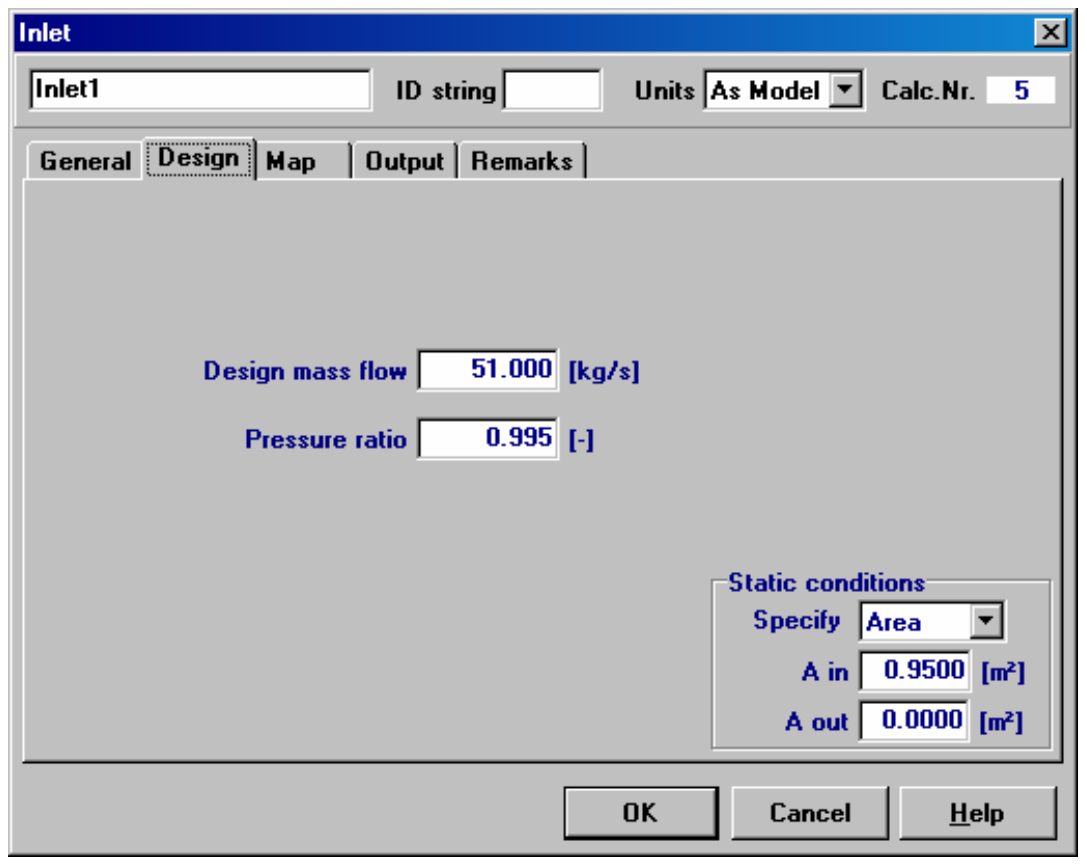

Figura C.1: Definição do ponto de projeto do coletor dinâmico.

Ventilador: para modelar o ponto de projeto do ventilador é necessário definir razão de derivação, a velocidade de rotação e a razão de pressão e eficiência para os fluxos primário e secundário conforme especificado na Figura C.2. 


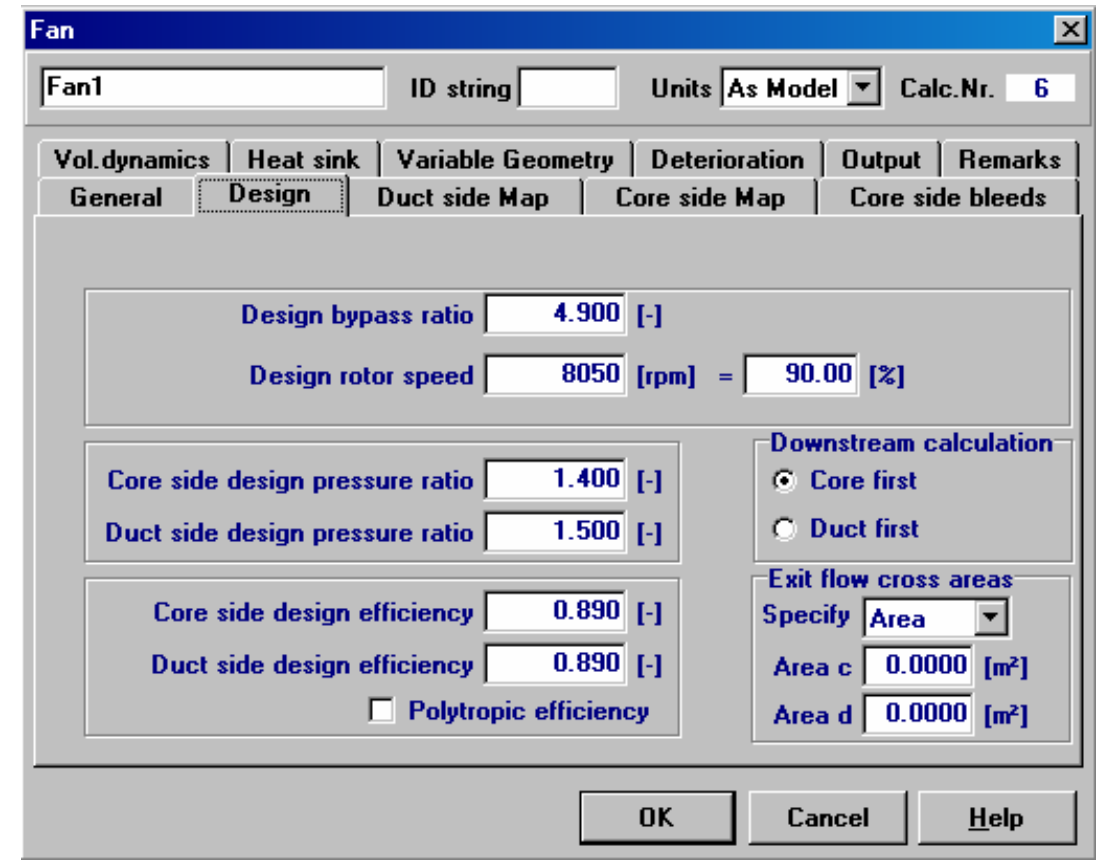

Figura C.2: Definição do ponto de projeto do ventilador.

Compressor: assim como no ventilador, é preciso definir no ponto de projeto a velocidade de rotação, a relação de compressão e a eficiência como visualizado na Figura C.3.

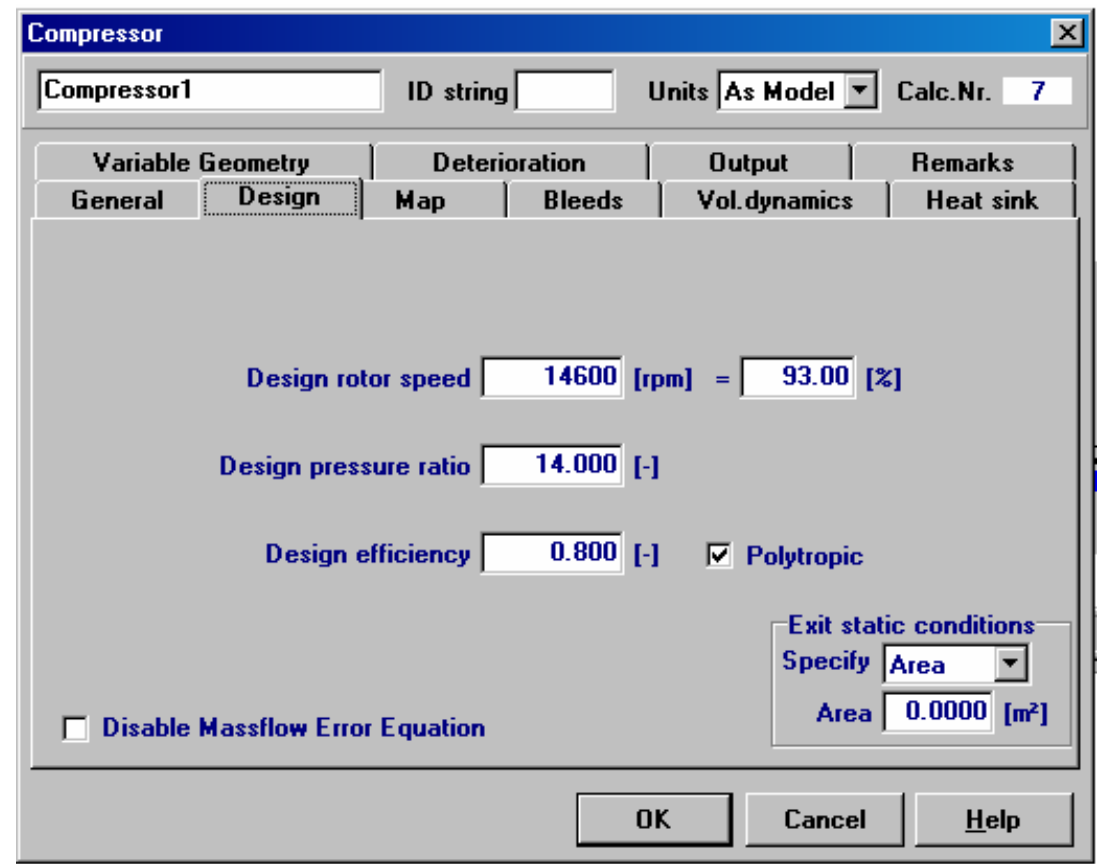

Figura C.3: Definição do ponto de projeto do compressor. 
Câmara de combustão: na interface da câmara de combustão é necessário definir as condições de projeto da câmara e do combustível utilizado, conforme mostrado na Figura C.4 e Figura C.5 respectivamente. Na simulação efetuada foram definidos o consumo de combustível e o tipo de combustível utilizado, que é do tipo Jet-A.

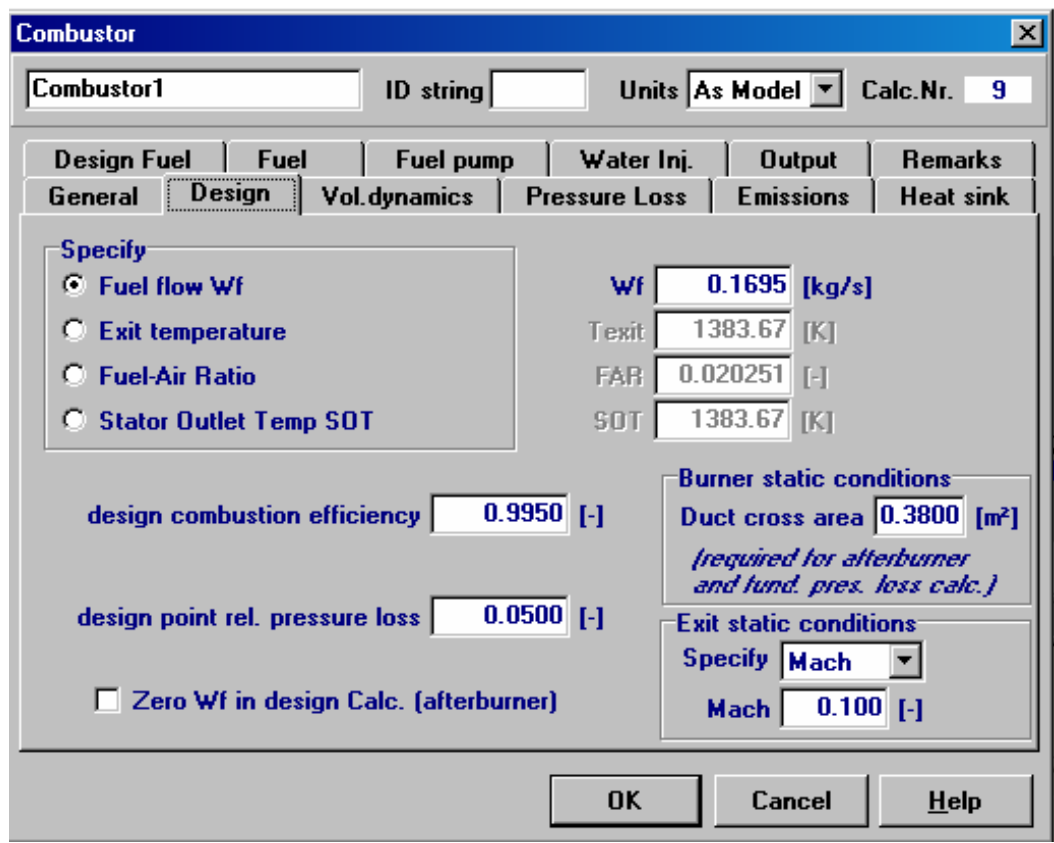

Figura C.4: Definição do ponto de projeto da câmara de combustão.

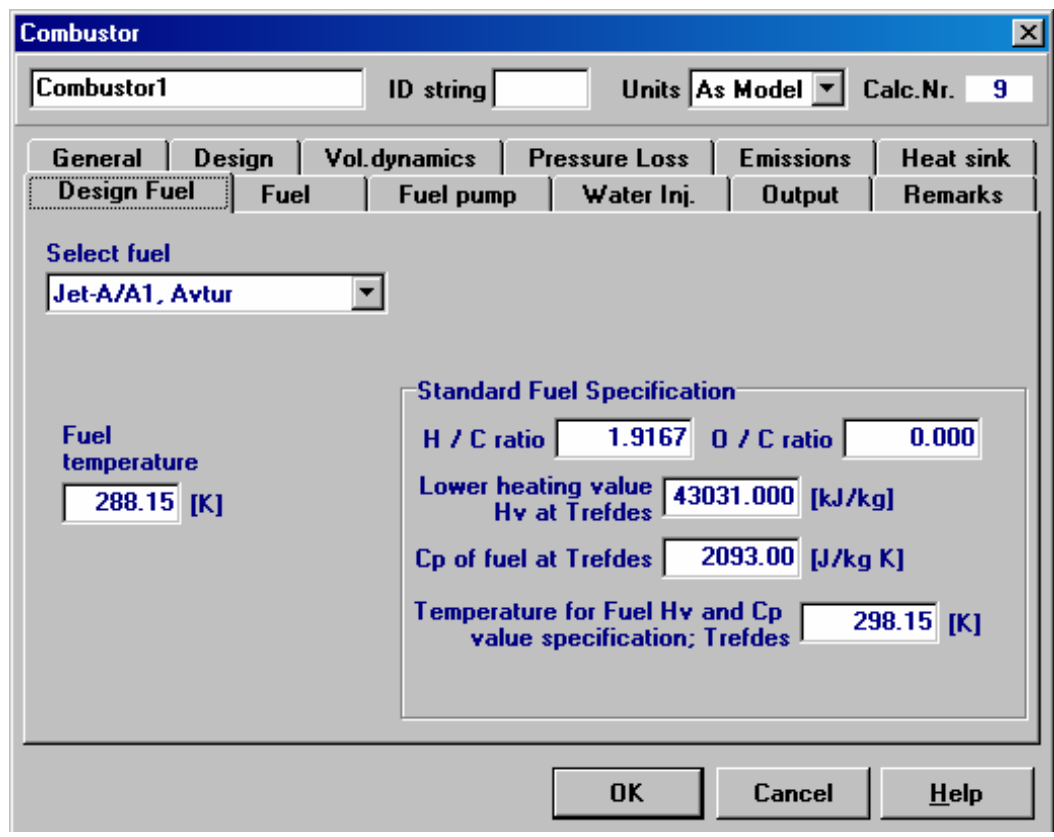

Figura C.5: Definição do ponto de projeto da câmara de combustão (combustível utilizado). 
Turbinas: o motor tem dois conjuntos de turbinas que movimentam dois eixos diferentes. Para definir o ponto de projeto das turbinas, deve-se introduzir a velocidade de rotação e a eficiência. A massa do fluxo de entrada é calculada por meio da massa do fluxo de saída do componente anterior (a câmara de combustão ou a turbina de alta pressão). Não é necessário introduzir a relação de expansão pois a mesma é calculada automaticamente pelo programa por meio do balanço das potências necessárias ao compressor e ventilador. O programa necessita como entrada só das velocidades de rotação de projeto e, nas simulações das condições fora de projeto, a velocidade é calculada durante o processo de iteração. Os pontos de projeto da turbina de alta pressão e de baixa pressão são especificados conforme Figura C.6 e Figura C.7, respectivamente.

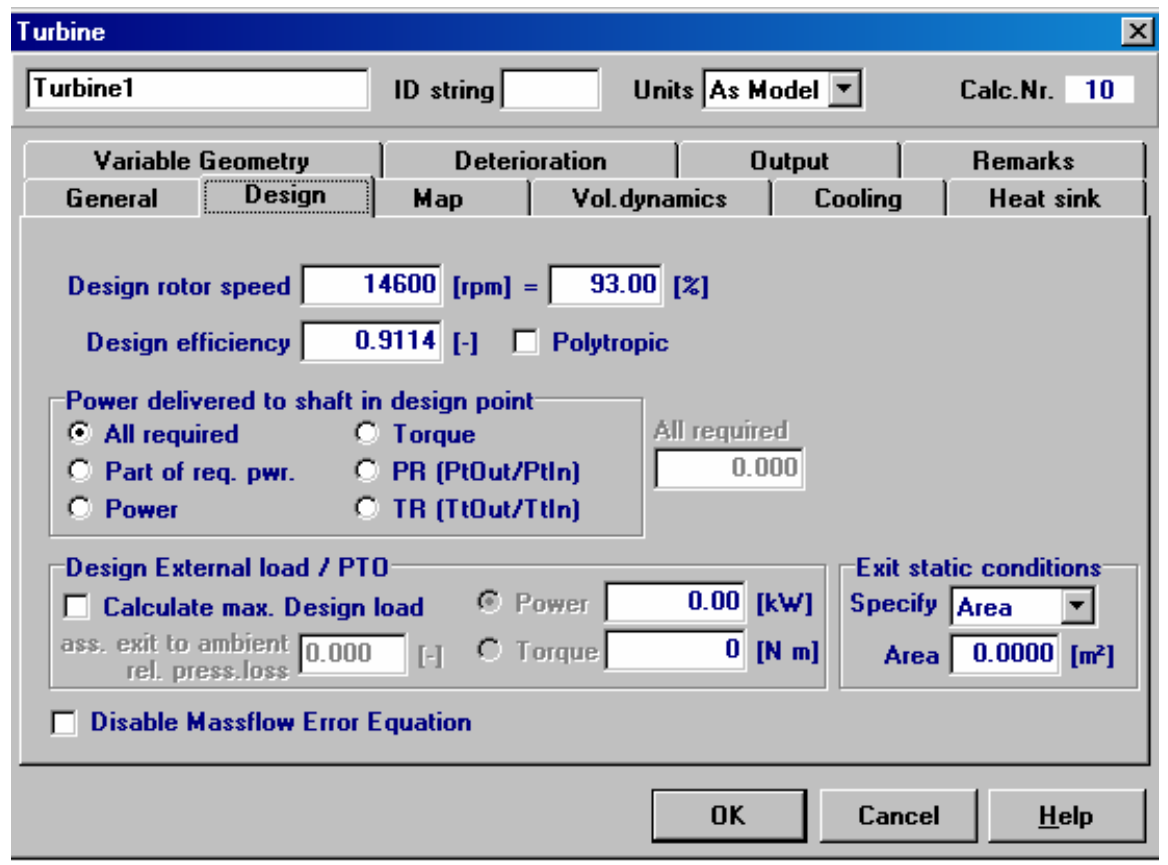

Figura C.6: Definição do ponto de projeto da turbina 1. 


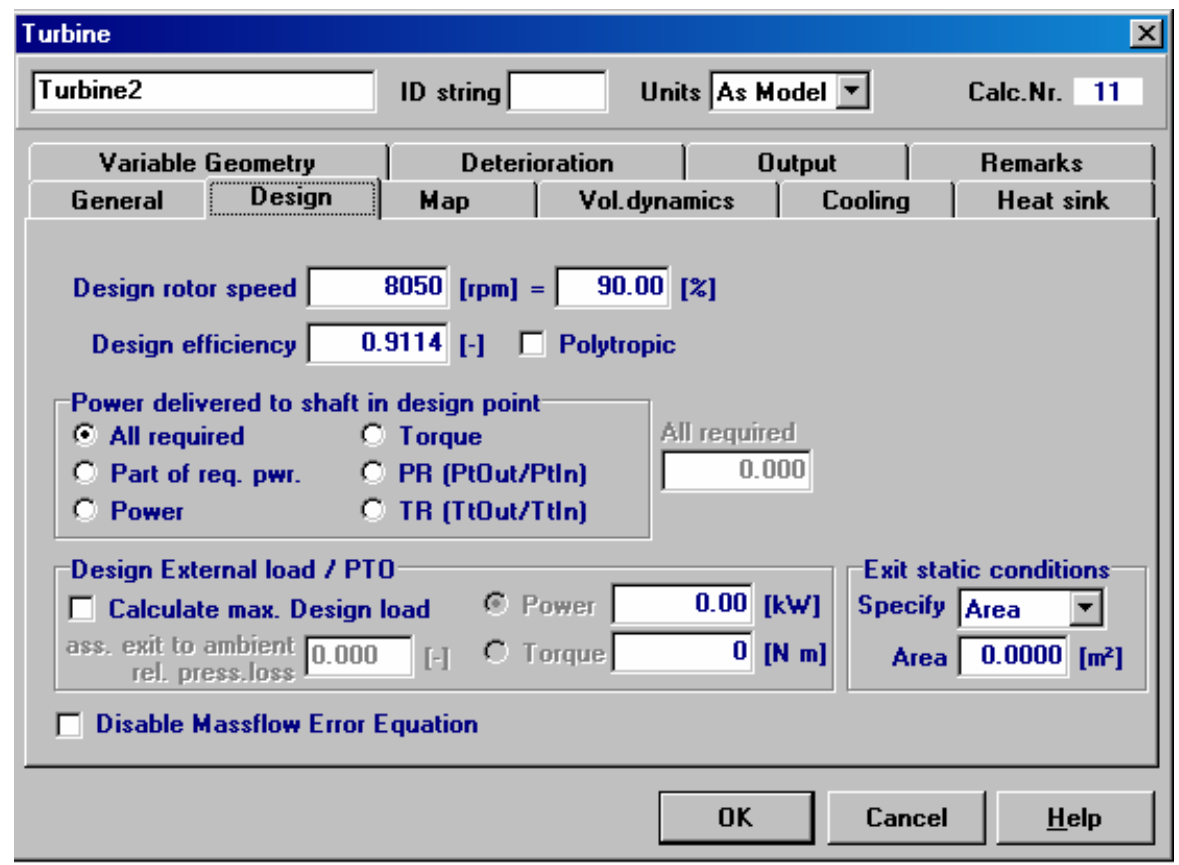

Figura C.7: Definição do ponto de projeto da turbina 2.

Misturador: utiliza-se um misturador para simular a mistura do fluxo primário e secundário em um único fluxo uniforme, assumindo que a mistura ocorre numa distância infinitesimal e sem perdas. As condições do fluxo de saída do misturador são calculadas pela equação de conservação da quantidade de movimento supondo que a relação de pressões estáticas dos fluxos de entrada seja constante. Para poder aplicar esta equação, é preciso calcular as condições estáticas e a velocidade de entrada e de saída. Para tanto, as áreas, os números de Mach ou as velocidades dos fluxos das seções externa e interna precisam ser especificados. As velocidades em Mach foram especificadas para as seções externa e interna conforme mostrado na Figura C.8; 


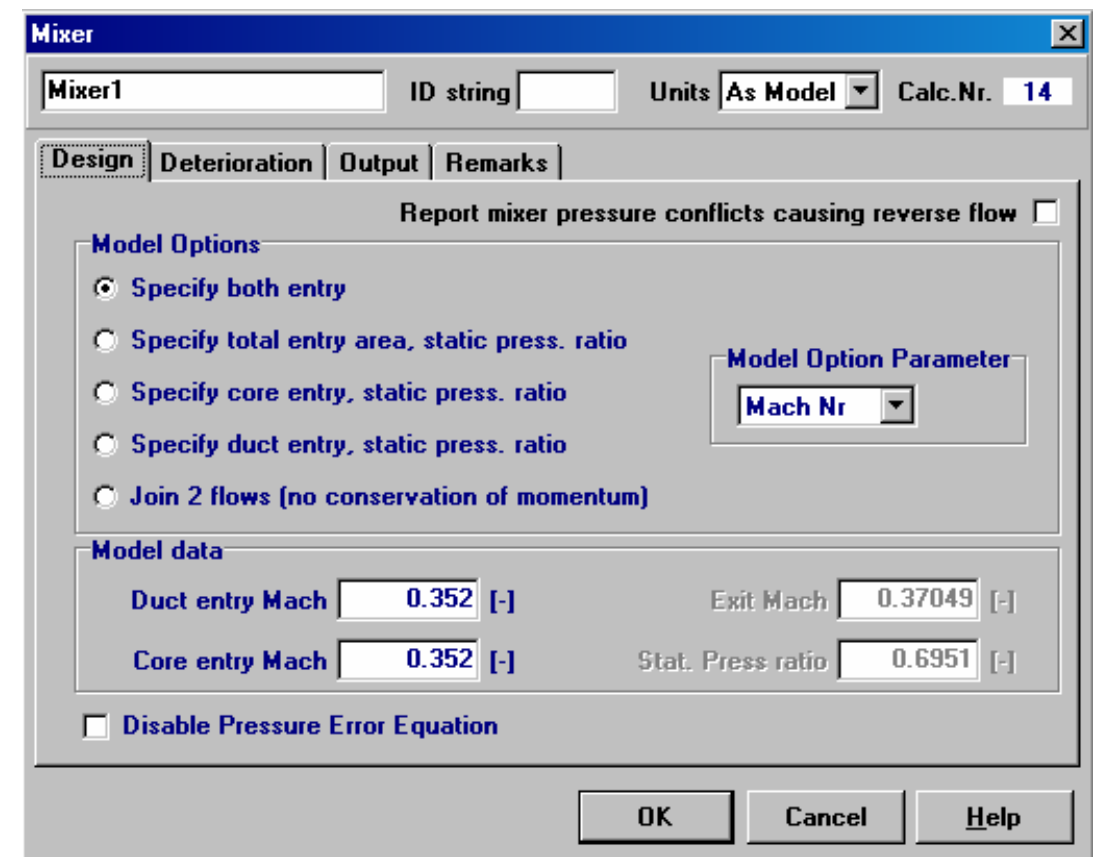

Figura C.8: Definição do ponto de projeto do misturador

Mapas dos componentes: o simulador GSP utiliza mapas característicos de cada componente para determinar as correlações de até cinco parâmetros típicos da condição de funcionamento do componente. Geralmente são utilizados um ou mais parâmetros entre:

- massa do fluxo corrigida;

- velocidade de rotação corrigida;

- relação de pressão;

- eficiência do componente;

- número de Reynolds.

A relação de pressão e o fluxo de massa corrigido são os parâmetros geralmente utilizados nos mapas. A velocidade de rotação e o rendimento isentrópico são utilizados exclusivamente nos componentes que representam turbomáquinas (compressor, ventilador e turbinas). Para definir as condições de operação e para determinar os valores dos outros parâmetros de saída, é necessário utilizar mais de três parâmetros de entrada (inclusive o número de Reynolds).

Os mapas podem ser escalados para diferentes componentes do motor. O GSP oferece a possibilidade de escalar os parâmetros para adaptá-los a um mapa parecido dentre aqueles contidos na biblioteca do programa. Normalmente este procedimento não introduz grandes 
erros para componentes geometricamente similares e com pontos de operação próximos. Os mapas utilizados na modelagem do motor são provenientes da biblioteca do programa GSP e podem ser visualizados na Figura C.9, na Figura C.10 e na Figura C.11. O ponto amarelo nas figuras representa o ponto de projeto.

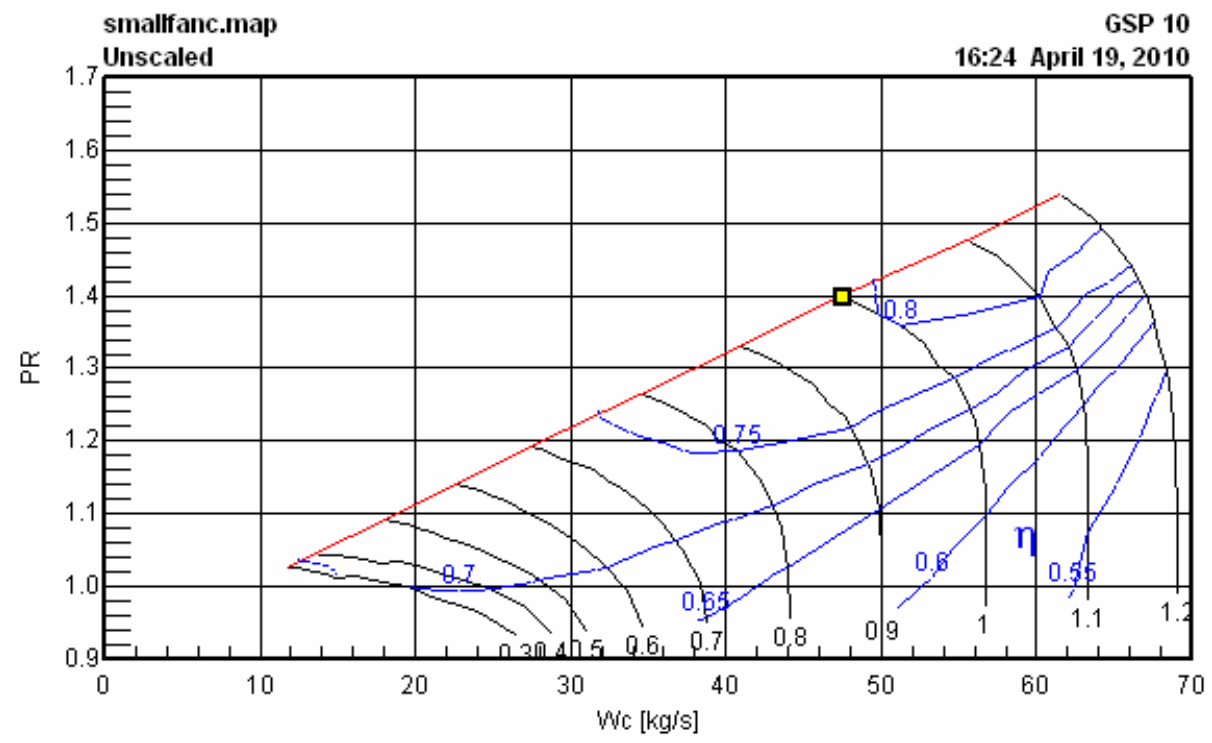

Figura C.9: Mapa do ventilador para o fluxo interno.

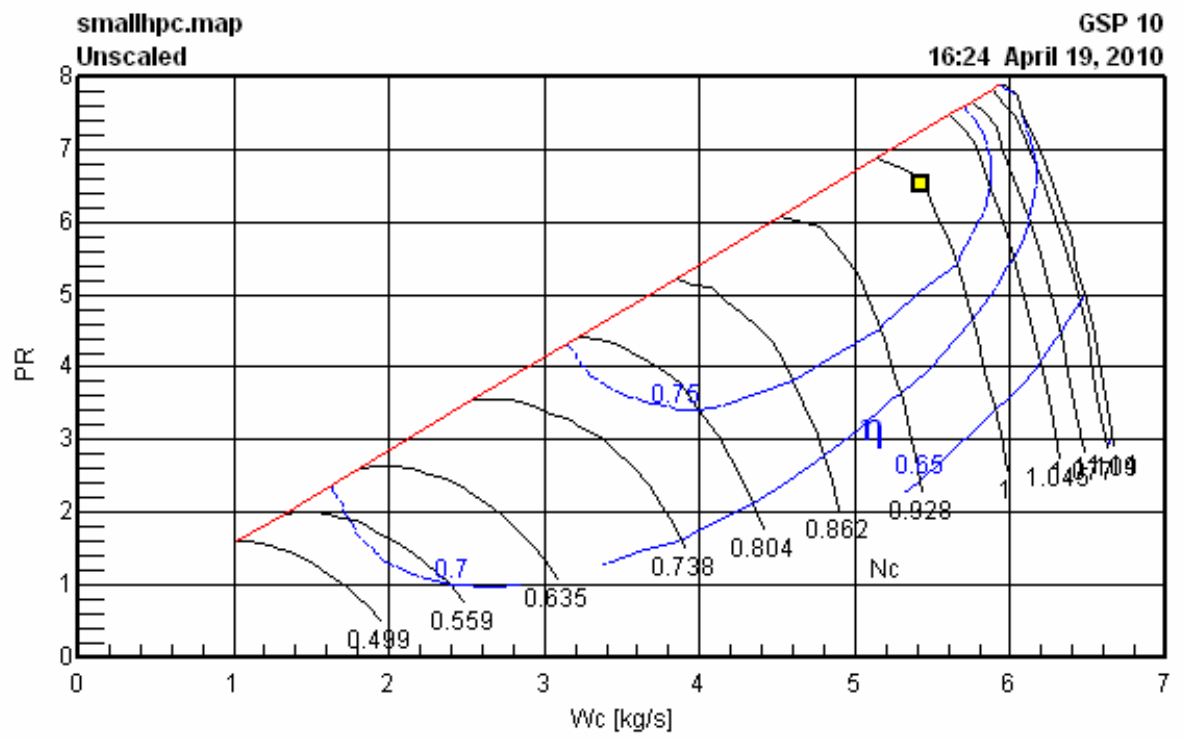

Figura C.10: Mapa do compressor. 


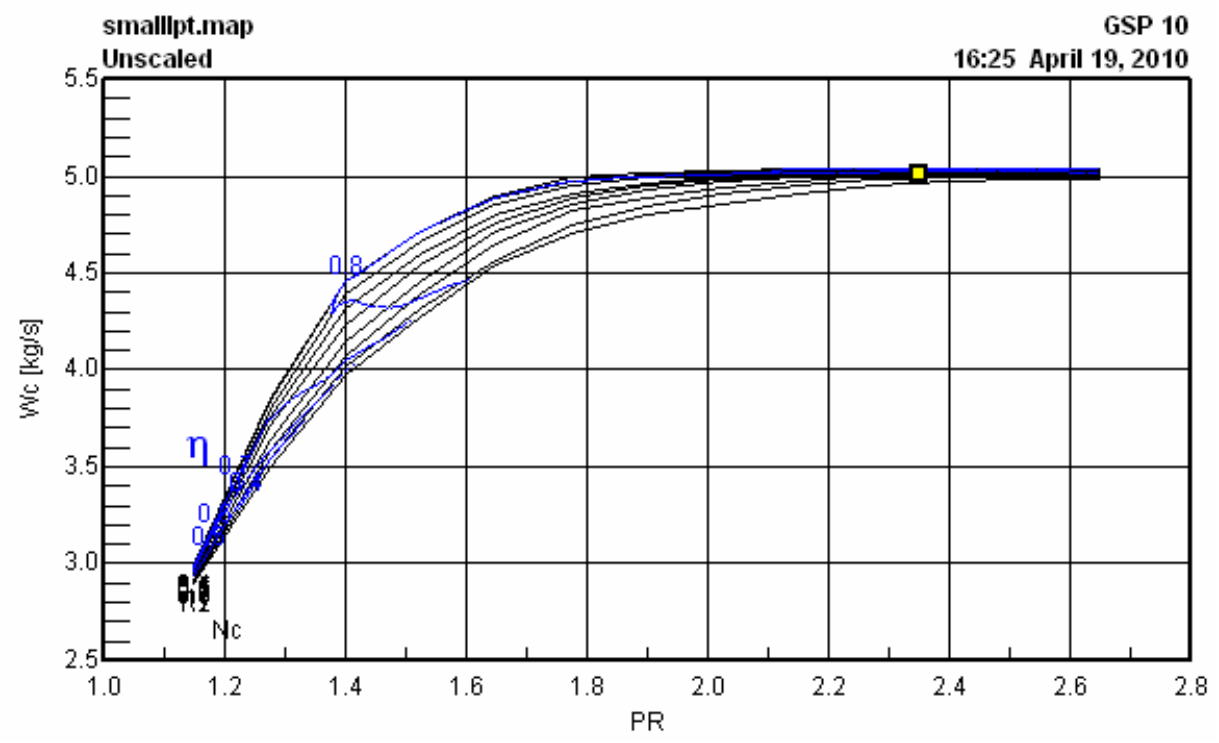

Figura C.11: Mapa da turbina de alta pressão. 


\section{Apêndice D. Resultados adotando ambiente de referência fixo no solo.}

Ao utilizar ambiente de referência fixo no solo e, devido ao movimento do avião relativo à referência, deve-se contabilizar as parcelas de exergia potencial de todos os fluxos de massa e as parcelas de exergia cinética dos fluxos de massa que possuem a mesma velocidade do avião. Conforme dito na seção 9.1, as parcelas de exergia cinética dos fluxos $\dot{B}_{A r}$ e $\dot{B}_{T C, e}$ não são contabilizadas para ambiente de referência fixo no solo .

Os valores de eficiência exergética dos sistemas, mostrados na Figura D.1 e na Figura D.2, são influenciados pelas parcelas de exergias cinética e potencial. Nota-se que, de uma maneira geral, as eficiências do motor, SEP, cabine e antigelo diminuíram e as eficiências da UCA aumentaram ao comparar com os valores obtidos usando a referência variável, principalmente nas fases de voo de 2 a 8 , nas quais o avião está acima do solo (vide Figura 9.8 e Figura 9.9 para ambiente de referência variável).

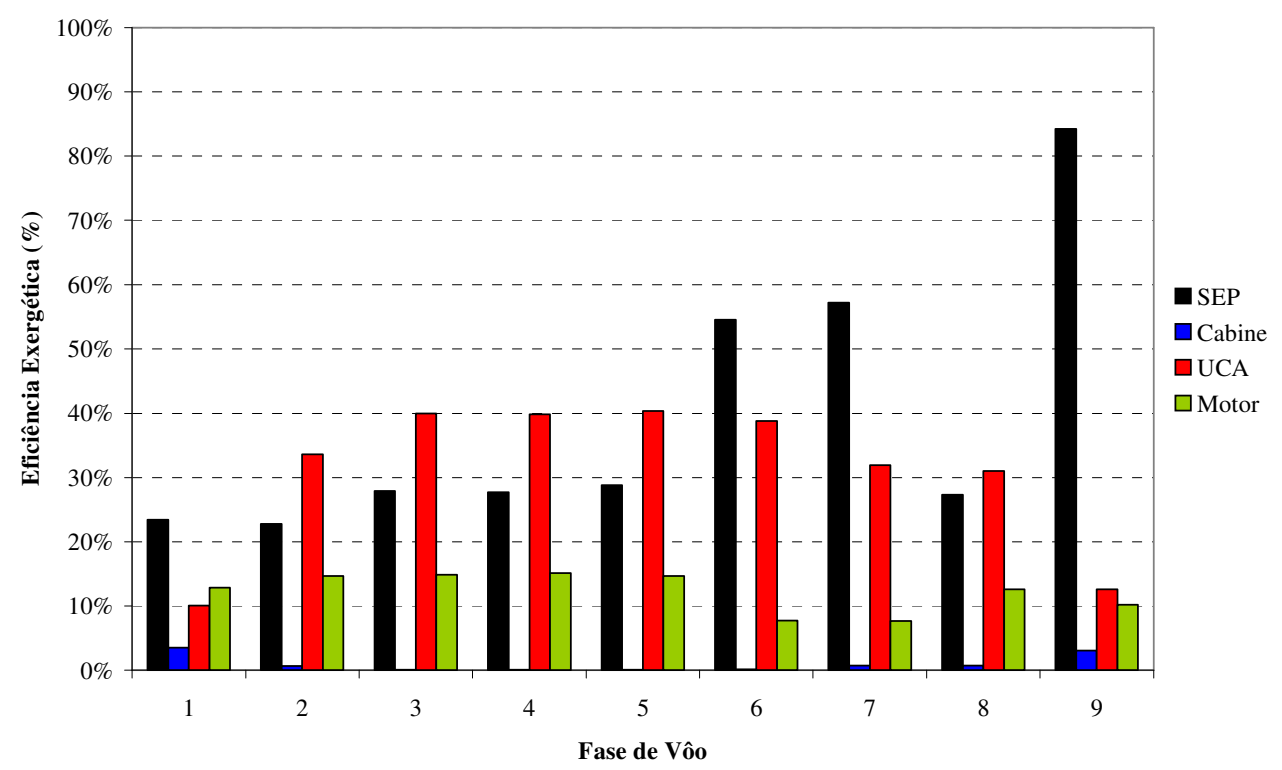

Figura D.1: Eficiência exergética do o avião com sistemas convencionais durante a missão com o sistema de antigelo desligado, usando ambiente de referência fixo no solo. 


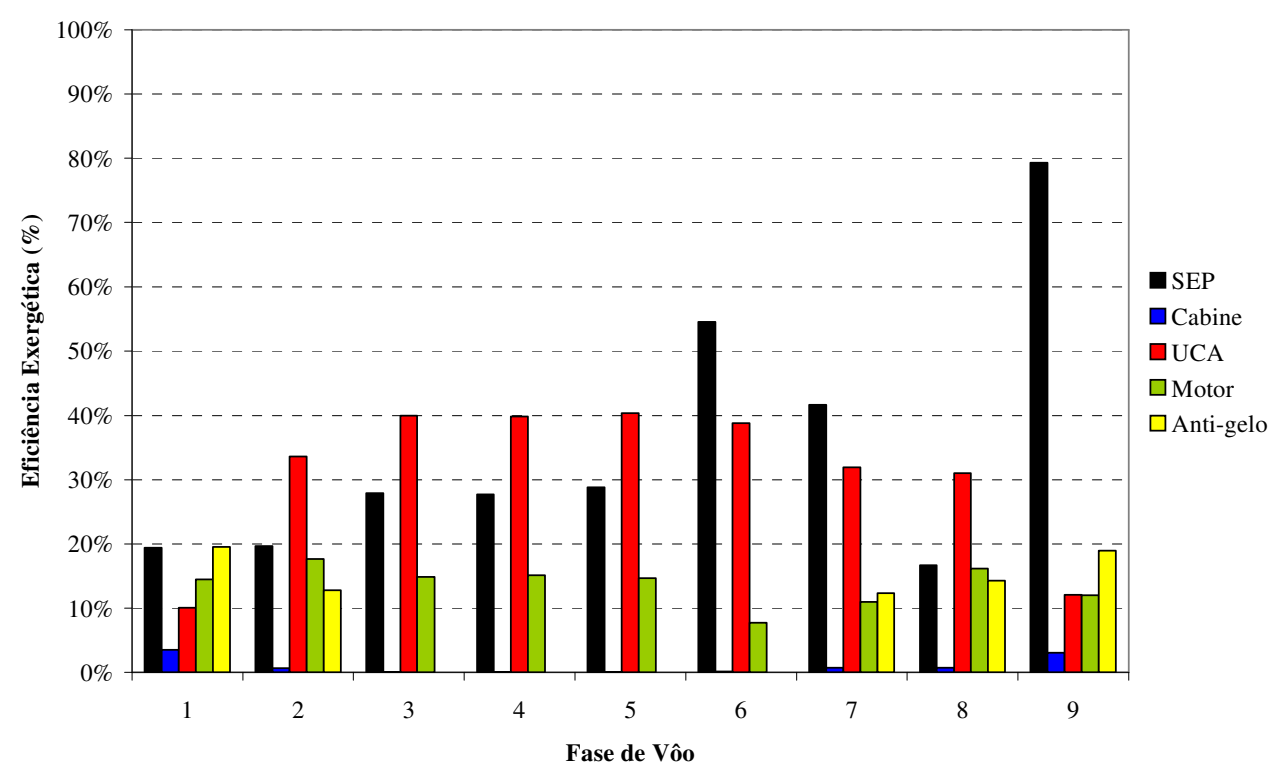

Figura D.2: Eficiência exergética do o avião com sistemas convencionais durante a missão com o sistema de antigelo ligado, usando ambiente de referência fixo no solo.

A hierarquia entre sistemas relacionada ao CEE e às irreversibilidades (maior valor para o menor valor) não deve ser alterada com a mudança do ambiente de referência. Isto significa que os valores absolutos de tais índices são dependentes do ambiente de referência escolhido, entretanto, a hierarquia entre valores é independente do ambiente de referência utilizado no cálculo da exergia, pois a mesma está intimamente relacionada às características de desempenho termodinâmico de cada sistema. Isto foi evidenciado conforme a Figura D.3, Figura D.4, Tabela D.1 e Tabela D.2 (vide resultados para ambiente de referência variável na Figura 9.14, Figura 9.15, Tabela 9.1 e Tabela 9.2)

Conforme mencionado na seção 5.6, a utilização das condições de estagnação por altitude é a abordagem correta para ao ambiente de referência pois contabiliza a exergia de forma mais representativa na análise de sistemas aeronáuticos. 


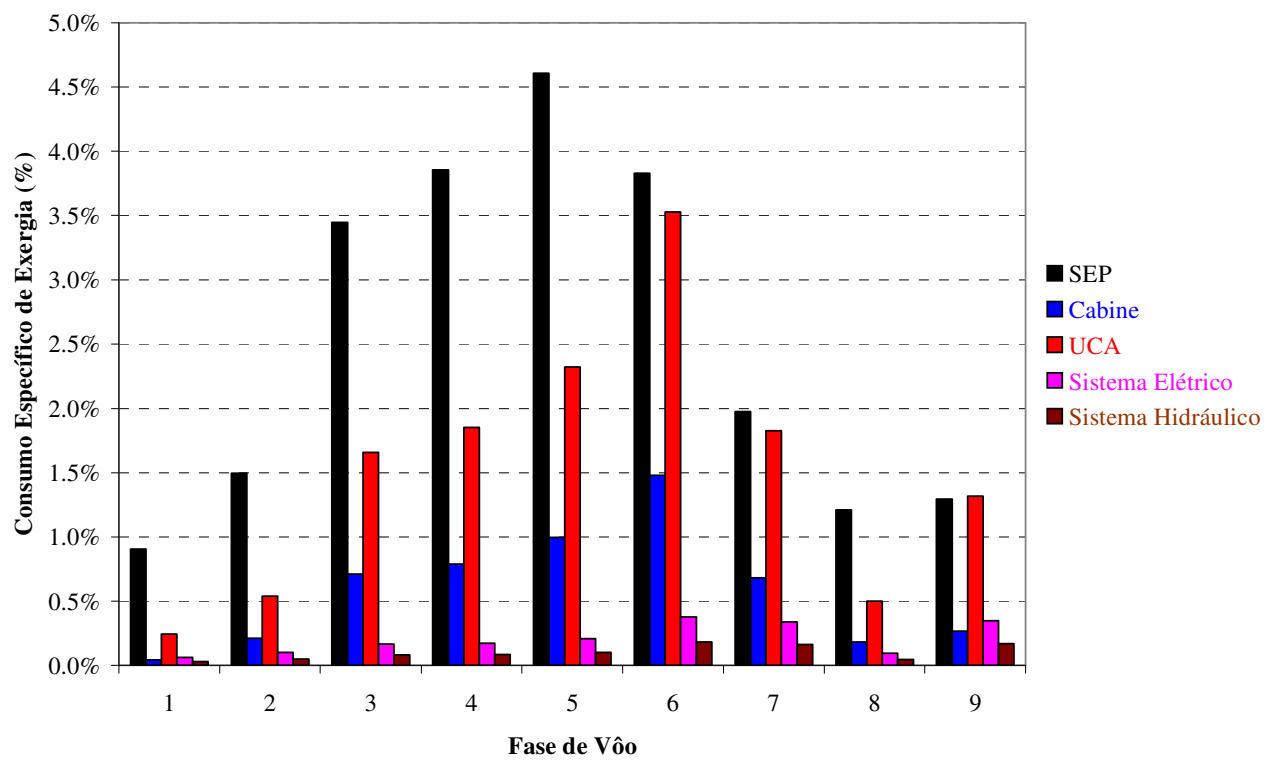

Figura D.3: Consumo específico de exergia para o avião com sistemas convencionais com o sistema de antigelo desligado, usando ambiente de referência fixo no solo.

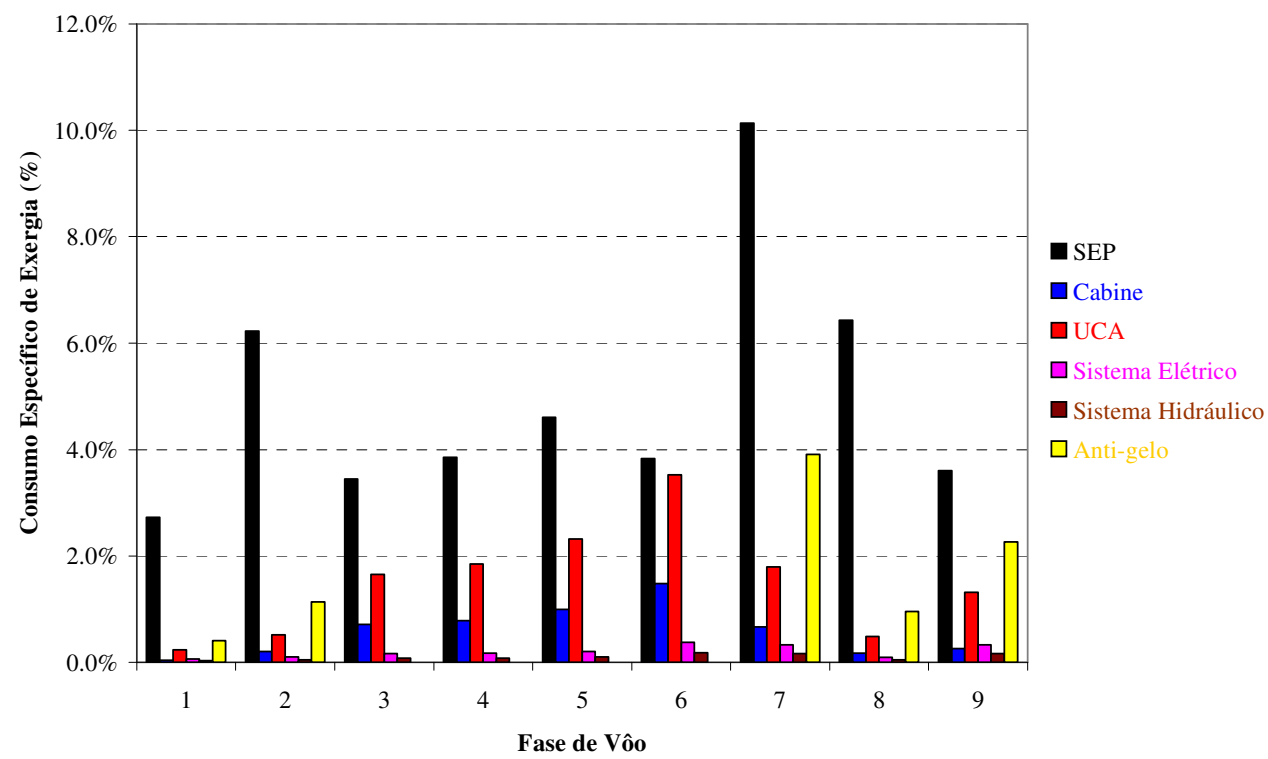

Figura D.4: Consumo específico de exergia para o avião com sistemas convencionais com o sistema de antigelo ligado, usando ambiente de referência fixo no solo. 
Tabela D.1: Irreversibilidades associadas aos sistemas convencionais (sistema de proteção contra gelo desligado e usando ambiente de referência fixo no solo) ${ }^{1}$.

\begin{tabular}{|c|c|c|c|c|c|c|c|c|}
\hline \multirow{2}{*}{ Fase de voo } & \multirow{2}{*}{$\begin{array}{c}\text { Altitude } \\
\text { [m] }\end{array}$} & \multicolumn{7}{|c|}{ Irreversibilidades [kW] } \\
\hline & & SEP & UCA & Cabine & Sistema Elétrico & Antigelo & Motor & Total \\
\hline 1 - Decolagem & 0 & 110,60 & 34,94 & 6,66 & 0,20 & 0,00 & 14402,00 & 14554,40 \\
\hline 2 - Subida & 6096 & 114,10 & 35,39 & 20,79 & 0,20 & 0,00 & 12861,00 & 13031,48 \\
\hline 3 - Subida & 10668 & 152,70 & 61,16 & 43,62 & 0,20 & 0,00 & 9930,00 & 10187,68 \\
\hline 4 - Cruzeiro & 11277,6 & 164,90 & 65,89 & 46,60 & 0,20 & 0,00 & 9818,00 & 10095,59 \\
\hline 5 - Cruzeiro & 12496,8 & 160,00 & 67,54 & 48,60 & 0,20 & 0,00 & 8566,00 & 8842,34 \\
\hline 6 - Descida & 10668 & 47,09 & 58,41 & 39,92 & 0,20 & 0,00 & 7466,00 & 7611,62 \\
\hline 7 - Descida & 6096 & 25,52 & 37,54 & 20,46 & 0,20 & 0,00 & 6559,00 & 6642,72 \\
\hline 8 - Espera & 4572 & 92,42 & 36,24 & 19,17 & 0,20 & 0,00 & 12864,00 & 13012,03 \\
\hline $\begin{array}{l}9 \text { - Aproximação e } \\
\text { aterrissagem }\end{array}$ & 0 & 5,99 & 33,81 & 7,63 & 0,20 & 0,00 & 2948,00 & 2995,63 \\
\hline
\end{tabular}

Tabela D.2: Irreversibilidades associadas aos sistemas convencionais (sistema de proteção contra gelo ligado e usando ambiente de referência fixo no solo) ${ }^{1}$.

\begin{tabular}{|c|c|c|c|c|c|c|c|c|}
\hline \multirow{2}{*}{ Fase de voo } & \multirow{2}{*}{$\begin{array}{c}\text { Altitude } \\
\text { [m] }\end{array}$} & \multicolumn{7}{|c|}{ Irreversibilidades [kW] } \\
\hline & & SEP & UCA & Cabine & Sistema Elétrico & Antigelo & Motor & Total \\
\hline 1 - Decolagem & 0 & 357,00 & 34,94 & 6,66 & 0,20 & 53,92 & 14416,00 & 14868,72 \\
\hline 2 - Subida & 6096 & 514,30 & 35,39 & 20,79 & 0,20 & 101,60 & 12792,00 & 13464,28 \\
\hline 3 - Subida & 10668 & 152,70 & 61,16 & 43,62 & 0,20 & 0,00 & 9930,00 & 10187,68 \\
\hline 4 - Cruzeiro & 11277,6 & 164,90 & 65,89 & 46,60 & 0,20 & 0,00 & 9818,00 & 10095,59 \\
\hline 5 - Cruzeiro & 12496,8 & 160,00 & 67,54 & 48,60 & 0,20 & 0,00 & 8566,00 & 8842,34 \\
\hline 6 - Descida & 10668 & 47,09 & 58,41 & 39,92 & 0,20 & 0,00 & 7466,00 & 7611,62 \\
\hline 7 - Descida & 6096 & 181,50 & 37,54 & 20,46 & 0,20 & 105,42 & 6375,00 & 6720,12 \\
\hline 8 - Espera & 4572 & 580,20 & 36,24 & 19,17 & 0,20 & 88,64 & 12641,00 & 13365,45 \\
\hline $\begin{array}{l}9 \text { - Aproximação e } \\
\text { aterrissagem }\end{array}$ & 0 & 22,78 & 35,41 & 7,63 & 0,20 & 56,19 & 2997,00 & 3119,21 \\
\hline
\end{tabular}

${ }^{1}$ Valores relacionados ao funcionamento de um motor, durante operação usual com dois motores. 